EDY LENIN TEJEDA MONTALVAN

INVESTIGAÇÃO DO COMPORTAMENTO GEOTÉCNICO DE MISTURAS DE SOLO ARENOSO COM LODO DA ESTAÇÃO DE TRATAMENTO DE ÁGUA DO MUNICÍPIO DE CUBATÃO, SP

Área de concentração:

Engenharia Geotécnica

Orientador:

Profa. Dra. Maria Eugenia Gimenez Boscov

São Paulo

2016 


\title{
INVESTIGAÇÃO DO COMPORTAMENTO GEOTÉCNICO DE MISTURAS DE SOLO ARENOSO COM LODO DA ESTAÇÃO DE TRATAMENTO DE ÁGUA DO MUNICÍPIO DE CUBATÃO, SP
}

\author{
Dissertação apresentada à Escola \\ Politécnica da Universidade de São Paulo \\ para obtenção do título de Mestre em \\ Ciências. \\ Área de concentração: \\ Engenharia Geotécnica \\ Orientador: \\ Profa. Dra. Maria Eugenia Gimenez Boscov
}


Este exemplar foi revisado e corrigido em relação à versão original, sob responsabilidade única do autor e com a anuência de seu orientador.

São Paulo, de de

Assinatura do autor:

Assinatura do orientador:

Montalvan, Edy Lenin Tejeda

Investigação do comportamento geotécnico de misturas de solo arenoso com lodo da estação de tratamento de água do município de Cubatão, SP / E.

L. T. Montalvan -- versão corr. -- São Paulo, 2016. $133 \mathrm{p}$.

Dissertação (Mestrado) - Escola Politécnica da Universidade de São Paulo. Departamento de Engenharia de Estruturas e Geotécnica.

1.Lodo de ETA 2.Resíduos sólidos 3.Compactação de solos 4.Permeabilidade do solo 5.Resistência dos solos I.Universidade de São Paulo. Escola Politécnica. Departamento de Engenharia de Estruturas e Geotécnica II.t. 


\section{DEDICATÓRIA}

Aos meus pais,

Betulia Montalvan

e Guillermo Tejeda. 


\section{AGRADECIMENTOS}

Meu infinito agradecimento aos meus pais Maria Betulia Montalvan e Raúl Guillermo Tejeda, pelo fundamental apoio durante meus estudos no Brasil.

À minha orientadora, professora Maria Eugenia Gimenez Boscov, primeiramente por ter aceitado a me orientar. Pela paciência no período de orientação, pelo apoio e ajuda constante quando eu tinha dúvidas. Pelo imenso trabalho, esforço e dedicação na revisão dos meus textos de dissertação e artigos. Pela amizade sincera, por todos os conselhos e incentivos durante o mestrado.

À minha namorada e melhor amiga, Ana Figueroa, pela motivação e exemplo de persistência para conquistar meus sonhos, e por me apoiar em todo momento no mestrado.

Aos técnicos do Laboratório de Mecânica dos Solos da Escola Politécnica, Antônio Heitzmann, Joaquin Costa Junior, e Valdineia Dos Santos Silva, pela fundamental ajuda na realização de diversos ensaios. Agradecimento também ao Robert de Jesus Mendoza e ao professor Fernando Marinho pelo enorme auxílio e instruções na realização dos ensaios Triaxiais.

Ao professor Paulo Hemsi do Instituto Tecnológico de Aeronáutica, pelas valorosas sugestões na qualificação e recomendações diversas na pesquisa.

Aos professores do Programa de Pós-graduação em Geotecnia na Escola Politécnica da Universidade de São Paulo, cujos ensinamentos foram fundamentais na minha formação como mestre.

Aos funcionários da ETA Cubatão e do aterro sanitário de Botucatu pela ajuda no fornecimento do lodo e do solo, respectivamente.

Ao Programa de Alianças para a Educação e Capacitação (PAEC) e à Organização dos Estados Americanos (OEA) pelo apoio e financeiro. 


\section{RESUMO}

O descarte do lodo de ETA em corpos de água, como rios, tem sido ainda uma prática comum no Brasil. Alternativas frequentes de destinação têm sido a disposição do lodo em aterros sanitários ou industriais e na rede de esgoto. Porém, os padrões ambientais cada vez mais rígidos têm levado à procura de soluções mais econômicas e benéficas, com o aproveitamento do lodo de ETA como material para diversos usos. Uma das opções promissoras é a utilização do lodo de ETA misturado a solos naturais em obras geotécnicas, como revestimento de fundo e cobertura final de aterros sanitários e industriais, e na construção de aterros em geral. Nessa perspectiva, foram estudadas as propriedades geotécnicas de misturas de um solo laterítico arenoso com um lodo de ETA em três proporções solo:lodo (3:1, 4:1, e 5:1) em massa úmida. Foi realizada a caracterização química e mineralógica do solo e do lodo por meio de ensaios de difração de raios $X$, fluorescência de raios $X$, microscopia eletrônica de varredura, determinação de perda ao fogo, $\mathrm{pH}$, capacidade de troca catiônica, soma de bases trocáveis, carbono orgânico, matéria orgânica, entre outros. Foram determinados a curva granulométrica, a massa específica dos grãos e os limites de consistência do solo, do lodo e das misturas. Ensaios de adensamento, permeabilidade e compressão triaxial foram realizados em corpos de prova compactados do solo e das misturas. A caracterização geotécnica das misturas mostrou que a adição de lodo não altera significativamente a granulometria, a massa específica dos grãos e os limites de consistência do solo. Por outro lado, a secagem prévia ao ar das misturas alterou os parâmetros de compactação: a massa específica seca máxima aumentou e o teor de umidade ótimo diminuiu com a redução do teor de umidade inicial no ensaio de compactação. Os índices de compressão das misturas apresentaram-se maiores que o do solo, enquanto as condutividades hidráulicas das misturas foram menores que a do solo. $O$ ângulo de atrito efetivo das misturas apresentou aumento e a coesão efetiva diminuição a medida que a proporção de lodo acrescentado ao solo aumentou. As características e propriedades das misturas apresentaram valores aceitáveis para solos utilizáveis em aterros, o que possibilita o aproveitamento de lodo de ETA em misturas com solo a serem empregadas em obras geotécnicas.

Palavras-chave: lodo de ETA, mistura solo-lodo, compactação, adensamento, condutividade hidráulica, compressão triaxial. 


\section{ABSTRACT}

In Brazil, WTS is mostly released in water bodies causing silting and deterioration of water quality, destined to treatment with sewage, or disposed of in sanitary landfills or disposal sites of sewage treatment plants mixed with sewage sludge after a partial dewatering process. An alternative for WTS destination is its application, in natura, treated or mixed with soil, as construction material for covers and bottom liners of sanitary and industrial landfills or in embankments in general. Addition of Water Treatment Sludge (WTS) to soils in earthworks may reduce land disposal of WTS and exploitation of natural soils. In this perspective, geotechnical properties of mixtures of a lateritic sandy soil with WTS in proportions 3:1, 4:1, and 5:1 (by wet weight) were evaluated. WTS and soil were subjected to chemical and mineralogical characterization by $\mathrm{X}$-ray fluorescence and $\mathrm{X}$-ray diffraction tests, and determination of loss on ignition, $\mathrm{pH}$, organic matter content, cation exchange capacity, exchangeable bases, and other chemical parameters. Particle-size distribution curve, specific gravity of solids, and Atterberg limits were obtained for WTS, soil and mixtures. One-dimensional consolidation, permeability and undrained triaxial compression tests were carried out on compacted specimens of the soil and the soil-WTS mixtures. Geotechnical characteristics of the mixtures resulted slightly different from those of the soil, on the other hand, previous air-drying affected the compaction parameters of the mixtures, the maximum dry unit weight increased and the optimum water content decreased for a decrease in the initial water content of the compaction test. Compression index of the mixtures were higher than the soil, whereas hydraulic conductivity decreased with WTS addition for different confining pressures and hydraulic gradients. Effective friction angle of the mixtures increased and effective cohesion decreased when increasing the proportion of WTS added in the mixture. Some of those geotechnical parameter values were acceptable for a compacted soil and indicate high possibility of reuse of this waste in geotechnical works.

Keywords: water treatment sludge, soil-WTS mixture, compaction, consolidation, hydraulic conductivity, undrained triaxial compression. 


\section{SUMÁRIO}

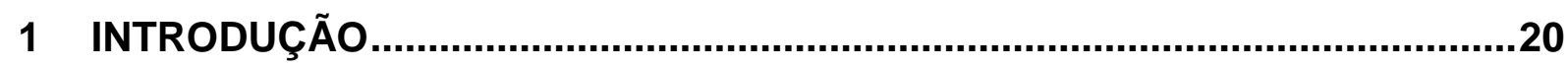

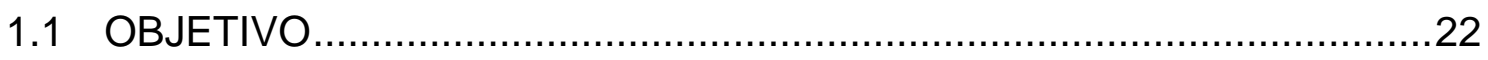

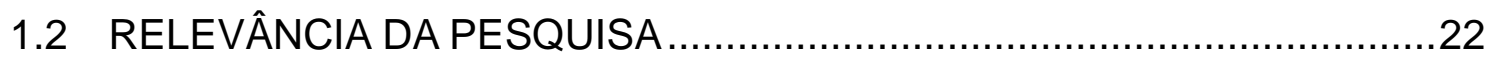

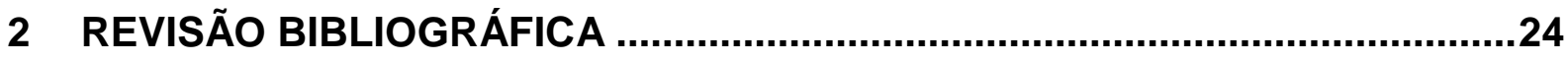

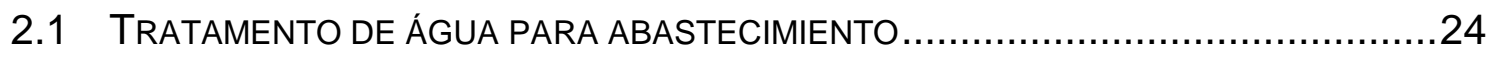

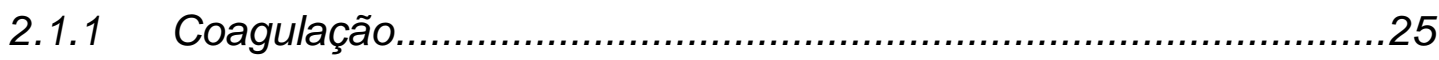

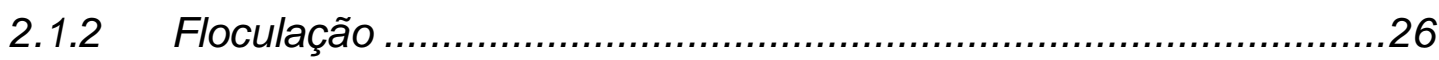

2.1.3 Decantação e/ou flotação ...........................................................26

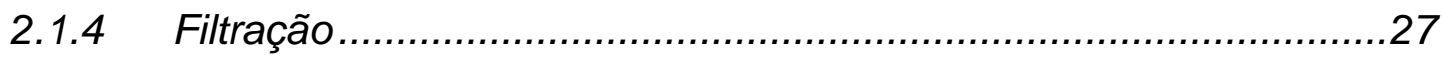

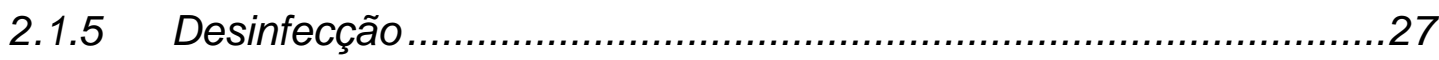

2.1.6 Fluoretação e correção de $\mathrm{pH}$....................................................28

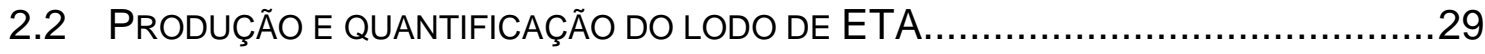

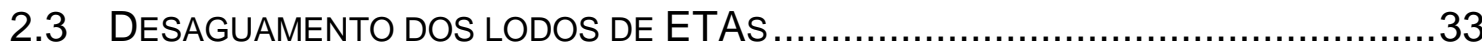

2.4 COMPOSIÇÃO MINERALÓGICA DOS LODOS DE ETA ………............................36

2.5 CaRACTERÍSTICAS FíSICO-QUímICAS DOS LOdOS DE ETAS............................37

2.6 COMPORTAMENTO GEOTÉCNICO DOS LODOS DE ETAS.................................42

2.6.1 Caracterização geotécnica ........................................................42

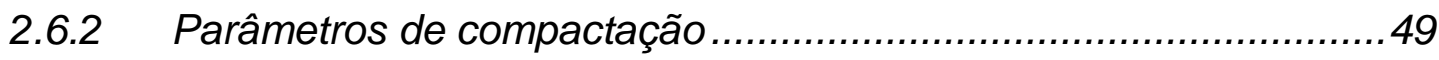

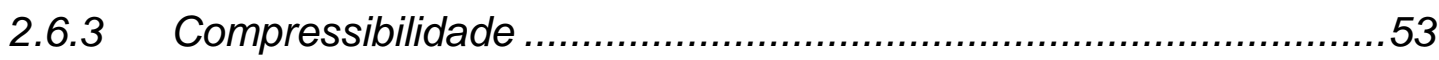

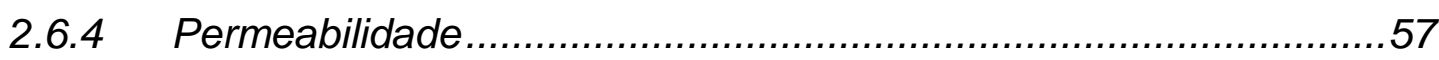

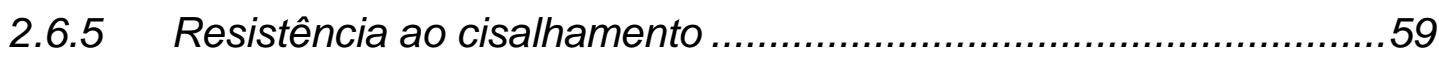

2.7 PARÂMETROS GEOTÉCNICOS DESEJÁVEIS EM SOLOS PARA CONSTRUCÇÃO DE

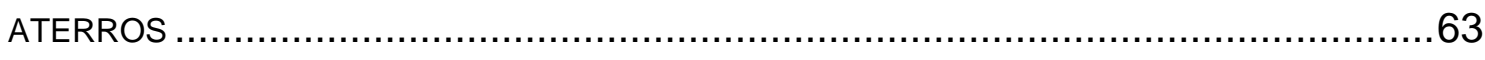

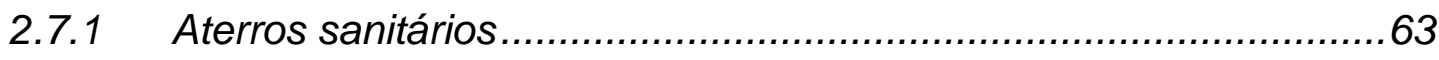

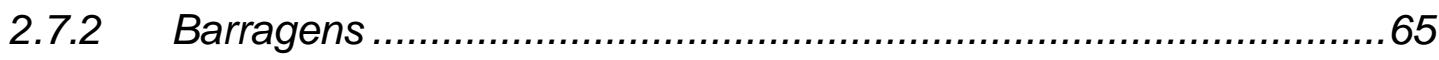




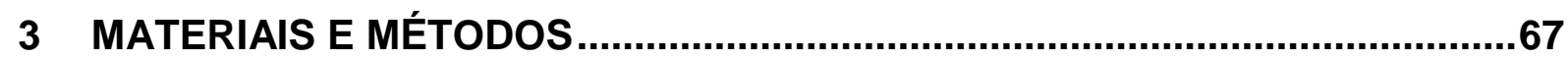

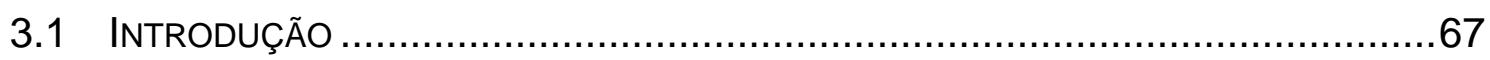

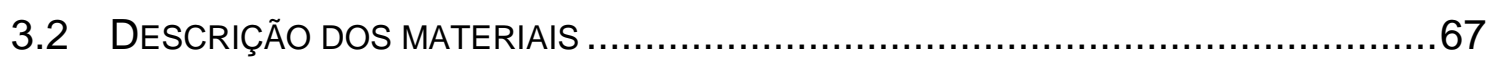

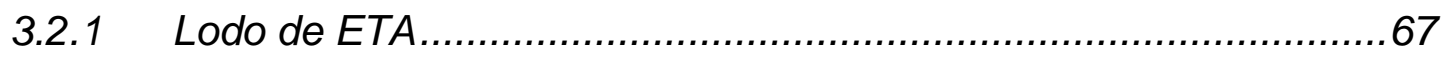

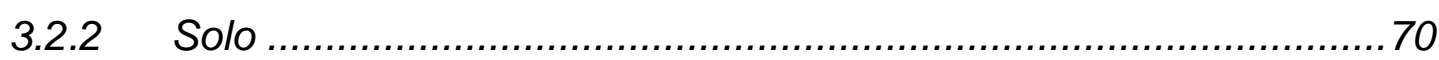

3.3 CARACTERIZAÇÃo QUÍMICA E MINERALÓGICA ..............................................72

3.3.1 Caracterização química do solo..................................................... 72

3.3.2 Caracterização mineralógica do solo ............................................ 72

3.3.3 Caracterização química do lodo …………….............................. 73

3.3.4 Caracterização mineralógica do lodo............................................. 74

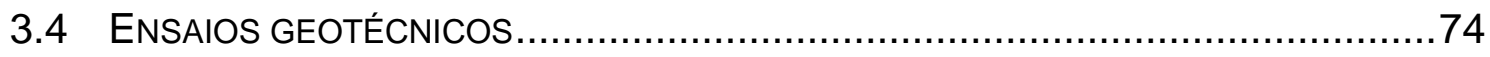

3.4.1 Preparação das amostras de solo, lodo e misturas ........................ 74

3.4.2 Caracterização geotécnica dos materiais ..................................... 77

3.4.3 Compactação do solo e das misturas ..........................................77

3.4.4 Preparação de corpos de prova para ensaios de deformabilidade, permeabilidade e resistência ...................................................................77

3.4.5 Deformabilidade do solo e das misturas..................................... 77

3.4.6 Permeabilidade do solo e das misturas ...................................... 78

3.4.7 Resistência ao cisalhamento do solo e das misturas ......................79

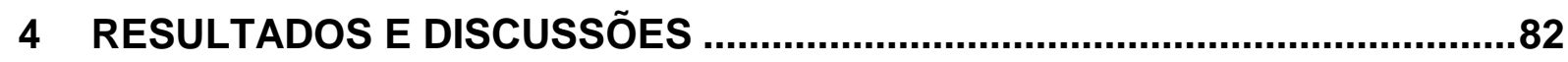

4.1 CARACTERIZAÇÃO QUÍMICA E MINERALÓGICA ............................................

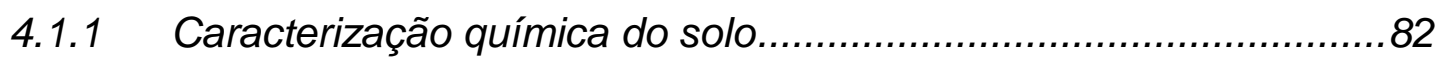

4.1.2 Caracterização mineralógica do solo ............................................ 82

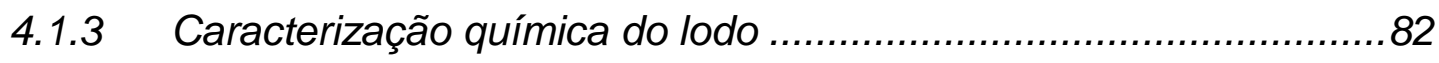

4.1.4 Caracterização mineralógica do lodo................................................ 84

4.2 ENSAIOS GEOTÉCNICOS COM O SOLO, O LODO E AS MISTURAS ........................89 
4.2.1 Caracterização geotécnica dos materiais ..................................89

4.2.2 Caracterização geotécnica do solo..........................................89

4.2.3 Caracterização geotécnica do lodo..........................................90

4.2.4 Caracterização geotécnica das misturas ..................................92

4.3 COMPACTAÇÃO DO SOLO E DAS MISTURAS ...................................... 95

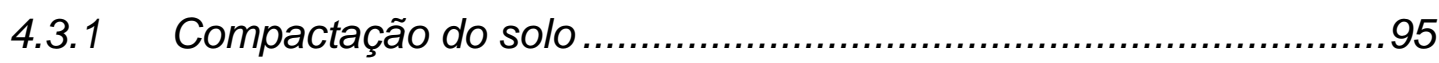

4.3.2 Compactação das misturas ................................................. 96

4.3.3 Compactação e moldagem de corpos de prova ..........................101

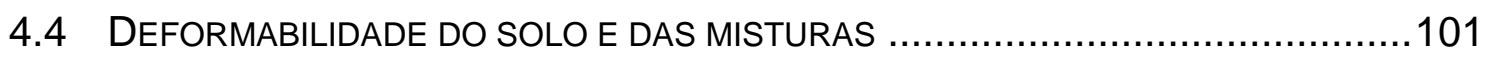

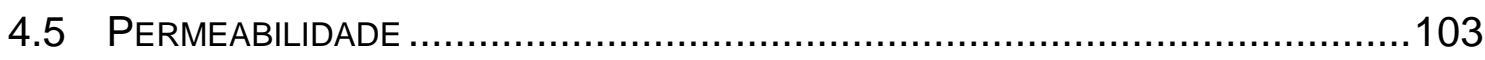

4.5.1 Permeabilidade em célula de adensamento ............................. 103

4.5.2 Permeabilidade do solo em permeâmetro de parede flexível....... 104

4.5.3 Permeabilidade das misturas em permeâmetro de parede flexível........................................................................................... 106

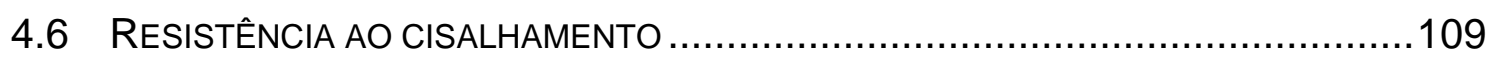

4.6.1 Resistência ao cisalhamento do solo..................................... 109

4.6.2 Resistência ao cisalhamento das misturas ..............................113

5 CONCLUSÕES......................................................................................... 122

6 RECOMENDAÇÕES ............................................................................ 124

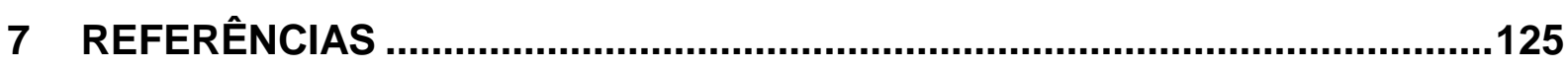




\section{LISTA DE ILUSTRAÇÕES}

Figura 2.1 - Esquema de funcionamento de uma ETA convencional. .....................24

Figura 2.2 - Tecnologia de Tratamento Convencional......................................25

Figura 2.3 - Cálculo da produção média mensal de sólidos em massa seca utilizando a formula do WRC.

Figura 2.4 - Variação da massa específica dos grãos com a temperatura de secagem do lodo.

Figura 2.5 - Variação da granulometria e da concentração de matéria orgânica ao longo dos meses de coleta do lodo da ETA Presidente Prudente, SP, Brasil.

Figura 2.6 - Curvas granulométricas de lodos de ETAs que utilizam coagulantes diferentes.

Figura 2.7 - Curvas granulométricas de lodo de ETA (Hitachi, Japão). 48

Figura 2.8 - Curvas de compactação de lodos ETA com secagem prévia. 51

Figura 2.9 - Curvas de compactação de lodos de ETA sem secagem prévia. 52

Figura 2.10 - Curvas de adensamento de diferentes lodos de ETA. 53

Figura 2.11 - Curvas de adensamento de distintas amostras de um lodo de ETA...55

Figura 2.12 - Curvas de adensamento de um lodo de ETA ensaiado em célula edométrica e em consolidômetro. .56

Figura 2.13 - Coeficientes de condutividade hidráulica de diferentes lodos de ETA....58 Figura 2.14 - Resistência não drenada de lodos de ETA obtida a partir de ensaio do cone.

Figura 2.15 - Resistência não drenada de lodos de ETA obtida a partir de ensaio de compressão simples. 63

Figura 3.1 - Localização da ETA Cubatão. .68

Figura 3.2 - Amostras de lodo da ETA armazenadas em sacos plásticos. 69

Figura 3.3 - Centrífuga utilizada na desidratação do lodo. 69

Figura 3.4 - Vista regional do sitio de amostragem do solo. .71 
Figura 3.5 - Preparação de mistura solo-lodo. .................................................76

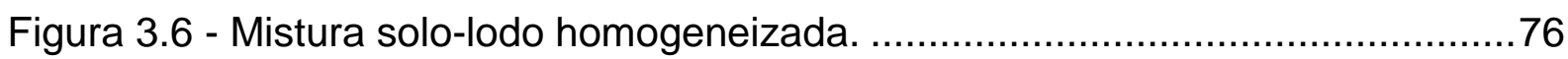

Figura 3.7 - Prensas e células de adensamento unidimensional.............................78

Figura 3.8 - Moldagem de corpo de prova e equipamento utilizado nos ensaios de permeabilidade de parede flexível.........................................................................79

Figura 3.9 - Montagem de corpo de prova na câmera triaxial. ................................80

Figura 3.10 - Execução de ensaio de compressão triaxial adensado não drenado (CAU) com medida de pressão neutra.

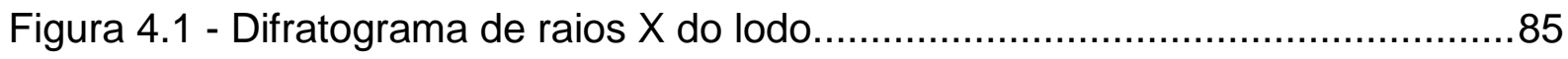

Figura 4.2 - Fases identificadas no difratograma de raios $\mathrm{X}$ do lodo.......................86

Figura 4.3 - Partículas de lodo vistas no Microscópio Eletrônico de Varredura (MEV) a $40000 x$.

Figura 4.4 - Partículas de caulinita presentes no lodo vistas no Microscópio Eletrônico de Varredura (MEV).

Figura 4.5 - Análise química das partículas de lodo por EDS. ...............................88

Figura 4.6 - Espectros de análises químicas pontuais (EDS) ..............................88

Figura 4.7 - Curvas granulométricas do solo, do lodo e das misturas.......................91

Figura 4.8 - Variação do teor de umidade do lodo na secagem ao ar.......................92

Figura 4.9 - Amostra de lodo prévio e após secagem ao ar. ...................................93

Figura 4.10 - Curvas de compactação do solo.....................................................96

Figura 4.11 - Curvas de compactação da mistura 3:1 ...........................................97

Figura 4.12 - Curvas de compactação da mistura 4:1 ..........................................97

Figura 4.13 - Curvas de compactação da mistura 5:1 .........................................97

Figura 4.14 - Variação do teor de umidade ótimo com a umidade inicial no ensaio de compactação das misturas. .99

Figura 4.15 - Variação da massa específica seca máxima com a umidade inicial no ensaio de compactação das misturas. 100 
Figura 4.16 - Variação da massa específica seca máxima com o teor de umidade

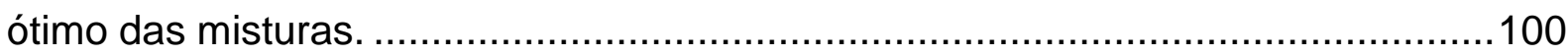

Figura 4.17 - Curvas de adensamento do solo e das misturas solo-lodo...............102

Figura 4.18 - Variação do coeficiente de condutividade hidráulica do solo e das misturas na célula de adensamento. 104

Figura 4.19 - Coeficiente de condutividade hidráulica do solo para distintos valores de pressão confinante e gradiente hidráulico. .105

Figura 4.20 - Coeficiente de condutividade hidráulica da mistura 5:1 para distintos valores de pressão confinante e gradiente hidráulico. 106

Figura 4.22 - Coeficiente de condutividade hidráulica da mistura 3:1 para pressão confinante de $30 \mathrm{kPa}$ e distintos valores de gradiente. hidráulico. 107

Figura 4.21 - Coeficiente de condutividade hidráulica da mistura 4:1 para distintos valores de pressão confinante e gradiente hidráulico. 107

Figura 4.23 - Corpo de prova da mistura 3:1 utilizado no ensaio de permeabilidade em permeâmetro parede flexível. 109

Figura 4.24 - Resultados do ensaio triaxial não drenado (CAU) no solo: curvas tensão-deformação e pressão neutra vs. deformação.

Figura 4.25 - Resultados do ensaio triaxial não drenado (CAU) no solo: Diagrama de trajetórias de tensões efetivas.

Figura 4.26 - Círculos de Mohr e envoltória de resistência em termos de tensões efetivas do solo.

Figura 4.27 - Resultados do ensaio triaxial não drenado (CAU) na mistura 3:1: curvas tensão-deformação e pressão neutra-deformação 114

Figura 4.28 - Resultados do ensaio triaxial não drenado (CAU) na mistura 4:1: curvas tensão-deformação e pressão neutra-deformação

Figura 4.29 - Resultados do ensaio triaxial não drenado (CAU) na mistura 5:1: curvas tensão-deformação e pressão neutra-deformação.

Figura 4.30 - Resultados do ensaio triaxial não drenado (CAU) na mistura 3:1: Diagrama de trajetórias de tensões efetivas. 
Figura 4.31 - Resultados do ensaio triaxial não drenado (CAU) na mistura 4:1: Diagrama de trajetórias de tensões efetivas.

Figura 4.32 - Resultados do ensaio triaxial não drenado (CAU) na mistura 5:1: Diagrama de trajetórias de tensões efetivas. ......................................................118 Figura 4.33 - Círculos de Mohr e envoltória de resistência em termos de tensões efetivas da mistura 3:1.

Figura 4.34 - Círculos de Mohr e envoltória de resistência em termos de tensões efetivas da mistura 4:1.

Figura 4.35 - Círculos de Mohr e envoltória de resistência em termos de tensões efetivas da mistura 5:1. 


\section{LISTA DE TABELAS}

Tabela 2.1 - Estimativa de produção de lodo nas principais ETAs da RMSP. .32

Tabela 2.2 - Concentração de sólidos por método de desaguamento. .35

Tabela 2.3 - Teor de sólidos obtidos mediante diferentes métodos de desaguamento de lodos de ETAs.

Tabela 2.4 - Composição mineralógica de lodos de ETAs de distintos países.

Tabela 2.5 - Características físico-químicas dos lodos de decantadores das estações de tratamento de água da região metropolitana de São Paulo. 39

Tabela 2.6 - Composição química de lodos de distintas ETAs. .40

Tabela 2.7 - Composição típica dos lodos de ETAs.

Tabela 2.8 - Características geotécnicas de lodos de ETAs que utilizam sulfato de alumínio como coagulante.

Tabela 2.9 - Características geotécnicas de lodos de ETAs que utilizam cloreto férrico como coagulante.

Tabela 2.10 - Características geotécnicas de lodos de ETAs que utilizam cloreto de polialumínio (PACL) como coagulante. 44

Tabela 2.11 - Características físicas e geotécnicas de lodo de ETA. .45

Tabela 2.12 - Limites de consistência de diferentes lodos de ETA. .49

Tabela 2.13 - Parâmetros de resistência de lodos de ETA, obtidos mediante ensaios de cisalhamento direto. 60

Tabela 2.14 - Parâmetros de resistência obtidos mediante ensaios triaxiais. 61

Tabela 2.15 - Requerimentos para camada de impermeabilização de fundo. 65

Tabela 2.16 - Parâmetros geotécnicos de solos residuais lateríticos utilizados na construção de barragens. .66

Tabela 3.1 - Resultados das análises químicas do solo......................................72

Tabela 3.2 - Composição mineralógica do solo......................................................73

Tabela 3.3 - Resultados do ensaio de fluorescência de raios X.............................73 
Tabela 4.1 - Resultados das análises químicas do lodo. .82

Tabela 4.2 - Resultados da análise de fluorescência de raios X do lodo. .84

Tabela 4.3 - Composição mineralógica do lodo .85

Tabela 4.4 - Resumo dos resultados da caracterização geotécnica dos materiais. .94 Tabela 4.5 - Parâmetros de compactação do solo e das misturas para distintos valores de teor de umidade inicial $\left(W_{i}\right)$ no ensaio de compactação. .98

Tabela 4.6 - Características dos corpos de prova compactados do solo e das misturas. 101

Tabela 4.7 - Índices de compressão e recompressão do solo e das misturas determinados no ensaio de adensamento. 102 Tabela 4.8 - Coeficientes de condutividade hidráulica $\left(\mathrm{k}_{20} \mathrm{em} \mathrm{m} / \mathrm{s}\right)$ do solo e das misturas para distintos valores de pressão confinante e gradiente hidráulico. 108 Tabela 4.9 - Parâmetros de resistência em termos de tensões efetivas das misturas e do solo. 120 


\section{LISTA DE ABREVIATURAS E SIGLAS}

ABNT

ABV

ASTM

AWWA

$\mathrm{CO}$

CTC

$\mathrm{CU}$

CAU

DBO

DRX

EDS

EMBRAPA

ETA

ETE

EUA

FAPESP

LCT-EPUSP

LMS-EPUSP

LSO-ESALQ

IBGE

ICDD

MEV
Associação Brasileira de Normas Técnicas

Alto da Boa Vista

American Society for Testing Materials

American Water Work Association

Carbono Orgânico

Capacidade de Troca Catiônica

Consolidated Undrained / Adensado Não Drenado

Anisotropically Consolidated Undrained / Adensado Anisotropicamente Não Drenado

Demanda Biológica de Oxigênio

Difratometria de Raios X

Energy Dispersive Spectroscopy / Espectroscopia por Energia Dispersiva

Empresa Brasileira de Pesquisa Agropecuária

Estação de Tratamento de Água

Estação de Tratamento de Esgoto

Estados Unidos da América

Fundação de Amparo à Pesquisa do Estado de São Paulo

Laboratório de Caracterização Tecnológica da Escola

Politécnica da Universidade de São Paulo

Laboratório de Mecânica dos Solos da Escola Politécnica da Universidade de São Paulo

Departamento de Ciência do Solo da Escola Superior de Agricultura Luiz de Queiroz

Instituto Brasileiro de Geografia e Estatística

International Centre for Diffraction Data

Microscopia Eletrônica de Varredura 
Silte de alta compressibilidade

$\mathrm{MO}$

Matéria Orgânica

PAC

Policloreto de Alumínio

PACL

Cloreto de Polialumínio

PAN-ICSD

PANalitycal Inorganic Cristal Structure Database

PF

Perda ao fogo

RMSP

Região Metropolitana de São Paulo

SABESP

Companhia de Saneamento Básico do Estado de São Paulo

SC

Areia Argilosa

SP

São Paulo

SUCS

Sistema Unificado de Classificação de Solos

UU

Unconsolidated Undrained / Não Adensado Não Drenado

USEPA

US Environmental Protection Agency

WRC

Water Research Centre 


\section{LISTA DE SIMBOLOS}

Al Dosagem de sulfato de alumínio

C

Cor d'água bruta

CA

Outros aditivos como carvão ativado

CP

Coeficiente de precipitação

C

Coesão

$c^{\prime}$

Coesão efetiva

$\mathrm{C}_{\mathrm{c}}$

Índice de compressão

$\mathrm{Cr}_{\mathrm{r}}$

Índice de recompressão

$\mathrm{C}_{\mathrm{v}}$

Coeficiente de adensamento

$\mathrm{C}_{\alpha \mathrm{e}}$

Índice de adensamento secundário

$\mathrm{C}_{\alpha \varepsilon}$

Coeficiente de adensamento secundário

D

Dosagem de coagulante

e

Índice de vazios

$\mathrm{Fe}$

Dosagem cloreto férrico

i

Gradiente hidráulico

IA

Índice de Atividade

IP

Índice de plasticidade

k

Coeficiente de condutividade hidráulica

LL

Limite de liquidez

LP

Limite de plasticidade

P

Produção de sólidos

$\mathrm{pH}$

Potencial hidrogeniônico ou potencial de hidrogênio

Q

Vazão

SS

Sólidos em suspensão

Turbidez 


$\begin{array}{ll}\text { Vv } & \text { Volume de vazios } \\ w & \text { Teor de umidade } \\ w_{\text {ot }} & \text { Teor de umidade ótimo } \\ w_{i} & \text { Teor de umidade inicial no ensaio de compactação } \\ \gamma_{d} & \text { Massa específica seca } \\ \gamma_{d} \text { máx } & \text { Massa específica seca máxima } \\ \sigma_{c} & \text { Pressão confinante ou tensão de adensamento } \\ \sigma_{3 c} & \text { Tensão principal menor de adensamento } \\ \varphi & \text { Ângulo de atrito } \\ \varphi^{\prime} & \text { Ângulo de atrito efetivo }\end{array}$




\section{INTRODUÇÃO}

O lodo de estação de tratamento de água (ETA) é o resíduo da produção de água potável a partir de água bruta. É composto de água, sólidos suspensos e produtos químicos aplicados no processo de tratamento (cloro, sulfato de alumínio e/ou cloreto férrico, cal ou soda cáustica, e flúor). Os sólidos do lodo compreendem, portanto, substâncias orgânicas (algas, bactérias, vírus e partículas orgânicas) e inorgânicas (coloides, areias, argilas, siltes, cálcio, magnésio, ferro, manganês, hidróxidos de alumínio e polímeros).

Embora estudos sobre geração de lodo de ETA sejam escassos na literatura, estima-se que atualmente no mundo são geradas mais do que 10 mil toneladas de lodo de ETA por dia (DHARMAPPA; HASIA; HAGARE, 1997; BABATUNDE; ZHAO, 2007; AHMAD; AHMAD; ALAM, 2016). A geração de lodo de ETA em 2004 na Europa foi de milhões de toneladas de lodo, com estimativa de duplicação da produção a cada 10 anos (BASIBUYUK; KALAT, 2004).

No Brasil existem cerca de 7.500 ETAs de ciclo completo ou convencional. Só no estado de São Paulo, a capacidade de produção de água potável da Companhia de Saneamento Básico do Estado de São Paulo (SABESP), responsável por 214 estações de tratamento de água, atinge $111.000 \mathrm{~L} / \mathrm{s}$, gerando estimadas 186 toneladas diárias de lodo em peso seco. A Região Metropolitana de São Paulo tem um consumo de aproximadamente $74.000 \mathrm{~L} / \mathrm{s}$ de água potável produzida em 28 estações de tratamento de água (SABESP, 2016), gerando aproximadamente 77 toneladas de lodo em peso seco por dia.

Essa grande quantidade de lodo, com tendência a aumento nos próximos anos, precisa de uma adequada destinação. Antigamente o lodo era jogado em corpos de água, pois era considerado um material inorgânico, ainda que contivesse um baixo teor de matéria orgânica, desprezando-se o efeito do aumento de turbidez da água e a possível presença de contaminantes, como metais e patógenos. Em alguns países da Europa, os lodos de ETA ainda são classificados como resíduo inerte e não existe legislação para sua disposição (BABATUNDE; ZHAO, 2007).

O descarte dos lodos de ETAs em corpos de água, como rios, tem sido ainda uma prática comum no Brasil, embora esses lodos sejam classificados pela NBR 
10004 (ABNT, 2004) como resíduos sólidos e, portanto, devam ser dispostos adequadamente. Segundo Cordeiro (1999), no Brasil eram lançadas cerca de 2.000 t/dia de lodo de ETA (base úmida) em cursos d'água em 1999. Não foi encontrada estimativa mais atualizada e é difícil dizer se a quantidade de lodo que continua sendo atualmente jogada em corpos d'água tem aumentado ou diminuído, pois houve incremento da produção de água potável em algumas ETAs ao mesmo tempo em que muitas ETAs passaram a transportar o lodo para aterros sanitários ou industriais ou a destinar o lodo de ETA para estações de tratamento de esgoto, em obediência à legislação ambiental cada vez mais rigorosa.

Porém, os padrões ambientais cada vez mais rígidos, as propriedades geotécnicas indesejáveis para aterramento, os altos custos de transporte e a falta de áreas em regiões urbanizadas têm levado vários pesquisadores de universidades e de empresas de saneamento a procurar em soluções alternativas que possam ser mais econômicas e benéficas para o aproveitamento e disposição final dos lodos de ETA (JANUÁRIO, 2005; AHMAD ET AL., 2016).

Pesquisas de laboratório e de campo sobre usos e disposição final dos lodos de ETAs têm sido reportadas na literatura por diversos autores no Brasil e no mundo, visando a sua disposição benéfica ou seu reuso como material em diferentes processos industriais, como: compostagem (SILVA; FERNANDES, 1998), controle de nutrientes em solos (CORNWELL; MUTTER; VANDERMEYDEN, 2000), cultivo de grama comercial (CORNWELL; MUTTER; VANDERMEYDEN, 2000), disposição em aterros sanitários (HSIEH; RAGHU, 1997), disposição em estações de tratamento de esgoto (DI BERNARDO; CARVALHO; SCALIZE, 1999), fabricação de cimento (CHEN; MA; DAI, 2010; KIKUCHI, 2001), fabricação de elementos cerâmicos (GOLDBOLD et al., 2003; MONTEIRO et al., 2008; MORITA et al., 2002), material de cobertura em aterros sanitários (RAGHU et al., 1987; WANG; HULL; JAO, 1992), uso como filler na fabricação de concreto asfáltico (DA SILVA, 2008; MARTINEZ, 2014), incorporação em matriz de concreto (HOPPEN et al., 2005), plantação de cítricos (CORNWELL; MUTTER; VANDERMEYDEN, 2000), recuperação de áreas degradadas (MOREIRA et al., 2009), recuperação de coagulantes (ABDO; EWIDA; YOUSSEF, 1993; PETRUZZELLI et al., 2000), reflorestamento (CORNWELL; MUTTER; VANDERMEYDEN, 2000), e uso na agricultura e silvicultura (HEIL; BARBARICK, 1989; MACHADO et al., 2004; TITSHALL; HUGHES, 2005). 
Uma das opções consideradas promissoras é a utilização do lodo de ETA misturado a solos naturais de propriedades geotécnicas adequadas, em quantidade limitada para não alterá-las significativamente. Preveem-se benefícios, portanto, de redução da disposição de resíduos na natureza e de preservação de recursos naturais (solos) pela sua substituição parcial por resíduos. Os principais problemas nesta aplicação são a determinação do teor de umidade do lodo de ETA a adicionar e a garantia de que a adição do lodo seja ambientalmente segura. Esta segurança ambiental tem que ser verificada de forma a que o uso de lodo de ETA como material corrente seja aceito pelos órgãos de controle ambiental.

\subsection{OBJETIVO}

O objetivo desta pesquisa é investigar o comportamento geotécnico de misturas de um solo arenoso com um lodo coletado da ETA do Município de Cubatão, SP, compreendendo a caracterização geotécnica (granulometria e limites de consistência), a compactação, a deformabilidade, a permeabilidade e a resistência ao cisalhamento, e definir o teor ou os teores de lodo que podem ser adicionados sem que haja perda significativa da qualidade geotécnica do solo natural compactado.

A possibilidade de utilização das misturas de solo com lodo de ETA em aplicações geotécnicas ainda dependerá de avaliação ambiental, tema de outra investigação dentro do escopo do projeto "Viabilização da utilização do lodo de ETA como material de cobertura de aterros sanitários e na construção de aterros em solos compactados", aprovado no Edital PESQUISA EM PARCERIA PARA INOVAÇÃO TECNOLÓGICA - ACORDO DE COOPERAÇÃO ENTRE FAPESP E SABESP de 2013 (Projeto FAPESP-SABESP 2013), no qual se insere esta pesquisa.

\subsection{RELEVÂNCIA DA PESQUISA}

Algumas pesquisas sobre utilização do lodo de ETA misturado ou não a solo (RODRIGUEZ et al., 2011; ROQUE; CARVALHO, 2006) têm demonstrado que o lodo seco e as misturas de solo com lodo seco apresentam um comportamento adequado para certas obras geotécnicas. Porém, o lodo de ETA ainda não é empregado como material de construção geotécnico devido à dificuldade em secá-lo. Até agora, o aproveitamento do lodo de ETA seco não tem sido viável do ponto de vista 
econômico, devido ao tempo, energia e espaço necessários para secar suficientemente o lodo tendo em vista as grandes quantidades geradas diariamente.

Surge, então, a ideia de utilizar o lodo de ETA na sua umidade in natura (definida como a umidade do material após desaguamento, realizado por centrífugas na ETA do Município de Cubatão, para disposição final), a qual normalmente é muito alta e variável de acordo com diversos fatores, como qualidade da água bruta, produtos químicos utilizados na ETA e método de desaguamento dos lodos. A utilização do lodo de ETA na umidade in natura seria mais econômica do que a do lodo seco, por não precisar de secagem prévia e, consequentemente, reduzir os custos associados. Por outro lado, é necessária a investigação da sua viabilidade técnica, que é a proposta deste trabalho.

Assim, as grandes quantidades de lodo geradas nas ETAs poderiam ser aproveitadas em obras geotécnicas, evitando que esses resíduos sejam lançados em corpos de água, transportados para estações de tratamento de esgoto (ETE) comprometendo a sua capacidade, ou levados para disposição em aterros sanitários ou industriais a elevados custos.

A literatura indica que o lodo de ETA se comporta como material inerte em diversos tipos de matrizes, o que indicou a possibilidade de uso em aterros e ensejou o estudo da viabilidade de aplicação geotécnica. Porém, uma vez comprovada a viabilidade da utilização de misturas solo-lodo de ETA em obras geotécnicas, é essencial a avaliação ambiental com estudos específicos para as aplicações propostas. 


\section{REVISÃO BIBLIOGRÁFICA}

\subsection{TRATAMENTO DE ÁGUA PARA ABASTECIMIENTO}

Os sistemas de abastecimento de água para população urbana requerem um conjunto de subsistemas, dos quais a estação de tratamento de água (ETA) é uma parte fundamental quando são utilizados mananciais superficiais (CORDEIRO, 1999).

O sistema de tratamento convencional de água compreende a seguinte série de processos unitários:

- coagulação;

- floculação;

- decantação e/ou flotação;

- filtração;

- e desinfecção.

De acordo com Cordeiro (1999), a maioria das ETAs utiliza o sistema de tratamento em ciclo completo ou convencional. Do volume total de água tratada distribuída no Brasil em 2008, 69,2\% receberam o tratamento convencional (IBGE, 2008). A Figura 2.1 mostra o esquema de funcionamento de uma ETA convencional. O fluxograma dos processos unitários no sistema de tratamento convencional está apresentado na Figura 2.2.

Figura 2.1 - Esquema de funcionamento de uma ETA convencional.

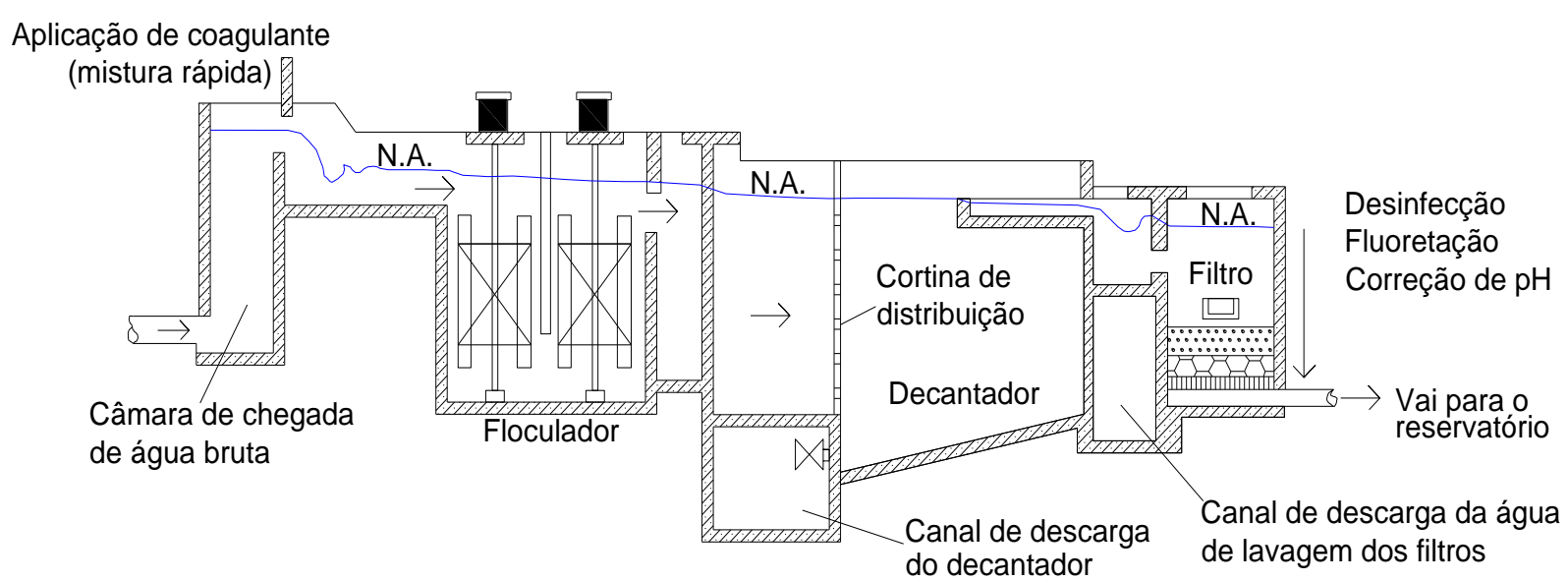

Fonte: adaptado de Heller e Pádua (2006) 
Figura 2.2 - Tecnologia de Tratamento Convencional.

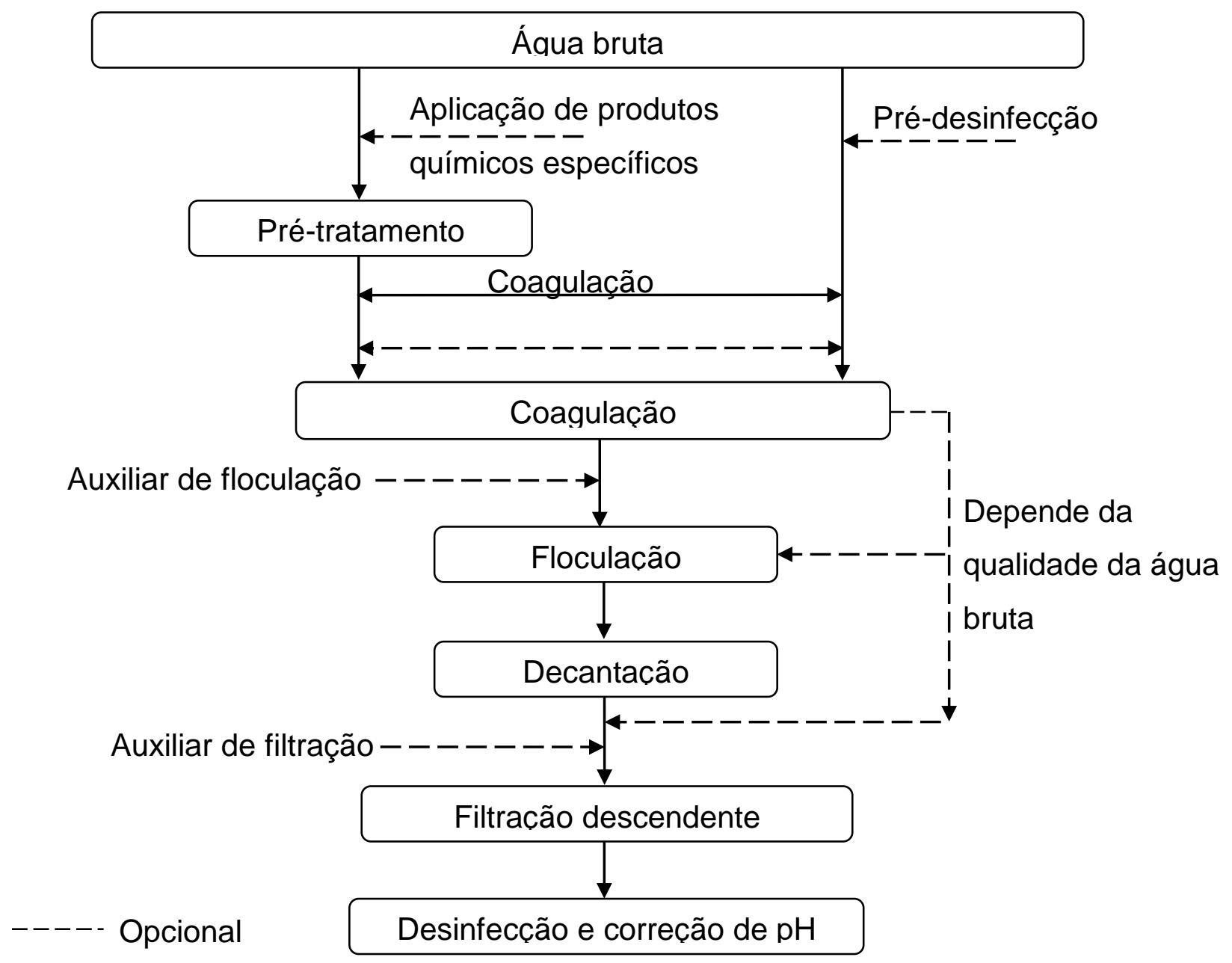

Fonte: adaptado de Di Bernardo (1993)

\subsubsection{Coagulação}

A água bruta pode conter uma variedade de impurezas, tais como partículas coloidais, substâncias húmicas (matéria orgânica do solo) e microrganismos em geral. Dado que essas impurezas apresentam carga superficial negativa, o que impede que as mesmas se aproximem, é necessária a aplicação de um produto químico coagulante que introduza cargas positivas no meio. Esse processo é realizado na unidade de mistura rápida na estação de tratamento. A mistura rápida promove a dispersão dos produtos químicos na água em tratamento, garantindo uma distribuição uniforme e com melhor aproveitamento. 
A coagulação é realizada mediante a adição de produtos químicos como cal, cloreto de polialumínio (PACL - polyaluminum chloride), policloreto de alumínio (PAC - aluminum polychloride) e sais de elementos que produzam hidróxidos gelatinosos, como os compostos de alumínio e ferro, entre eles sulfato de alumínio ("alum", $\left.\mathrm{Al}_{2}\left(\mathrm{SO}_{4}\right)_{3} .18 \mathrm{H}_{2} \mathrm{O}\right)$, sulfato ferroso $\left(\mathrm{FeSO}_{4} .7 \mathrm{H}_{2} \mathrm{O}\right)$, cloreto férrico $\left(\mathrm{FeCl}_{3} .6 \mathrm{H}_{2} \mathrm{O}\right)$, sulfato férrico $\left(\mathrm{Fe}_{2}\left(\mathrm{SO}_{4}\right)_{3}\right)$, sulfato ferroso clorado $\left(\mathrm{Fe}\left(\mathrm{SO}_{4}\right)_{3}+\mathrm{FeCl}_{3}+7 \mathrm{H}_{2} \mathrm{O}\right)$ e aluminato de sódio $\left(\mathrm{Na}_{2} \mathrm{Al}_{2} \mathrm{O}_{4}\right)$ (AZEVEDO NETTO, 1966). Em alguns casos podem ser empregados auxiliares de coagulação visando melhorar as condições de coagulação e decantação de águas relativamente claras, como polieletrólitos, terra de Fuller e bentonita (AZEVEDO NETTO, 1966), carvão ativado pulverizado e polímeros (HSIEH; RAGHU, 1997).

Existem tecnologias de tratamento que prescindem do processo de coagulação química para atender ao padrão de potabilidade requerido ou exigido pela normativa, em função da qualidade da água bruta, isto é, suas características biológicas, químicas e físicas (DI BERNARDO, 1993).

\subsubsection{Floculação}

Após o processo de coagulação na câmara de mistura rápida acontece a floculação na câmara de mistura lenta. Uma parte fundamental de todo sistema de sedimentação quimicamente melhorada é a agitação, a qual visa aumentar o contato entre partículas. A floculação é favorecida em condições de agitação moderada: ao aumentar o contato entre as impurezas, aumenta a aglomeração entre elas, formando partículas (flocos) maiores, que podem ser removidas por sedimentação, flotação e filtração (METCALF; HARRISON, 1985).

\subsubsection{Decantação e/ou flotação}

A decantação dos sólidos ocorre após os processos de coagulação-floculação nas unidades de decantação (decantadores) da ETA. A decantação ou sedimentação é o fenômeno físico no qual as partículas suspensas formadas durante a floculação apresentam movimento descendente em meio líquido de menor massa específica devido à ação da gravidade, indo depositar-se no fundo e formando lodo (DI BERNARDO; DI BERNARDO, 2005). Dado que as partículas coloidais presentes na água se sedimentam com velocidade muito baixa, a coagulação e a floculação se 
tornam imprescindíveis no processo de tratamento dependendo da qualidade da água bruta.

O processo de decantação, após a coagulação e floculação das impurezas, reduz consideravelmente o material suspenso e dissolvido na água antes da filtração. No entanto, existem casos nos quais a coagulação e floculação da água bruta produzem flocos de baixa velocidade de sedimentação e, portanto, elevados tempos de decantação das partículas. Uma alternativa para tratamento de águas dessa natureza é a utilização do processo de flotação (HELLER; PÁDUA, 2006). O processo de flotação é utilizado para separar partículas líquidas ou sólidas de uma fase líquida. A separação é bem-sucedida graças à introdução de bolhas de ar na fase líquida, que se aderem aos flocos e/ou partículas em suspensão, aumentando o empuxo e provocando a ascensão dos flocos até a superfície da água, de onde são removidos (HELLER; PÁDUA, 2006).

\subsubsection{Filtração}

O processo de decantação e/ou flotação é seguido pela filtração, a qual consiste na remoção de partículas suspensas, coloidais e microrganismos presentes na água que escoa através de um meio filtrante granular (DI BERNARDO; DI BERNARDO, 2005). Em uma ETA o processo de filtração, em geral, é o processo que completa o ciclo de remoção de impurezas presentes na água bruta. Existem dois tipos de filtração, lenta e rápida. Nas ETAs onde o tratamento da água é realizado mediante um processo biológico ao invés de coagulante químico, é usada a filtração lenta, enquanto nas ETAs convencionais, que utilizam produtos químicos como coagulantes, é empregada a filtração rápida.

Após certo tempo de filtração, é necessária a lavagem do filtro pela aplicação de fluxo de água no sentido ascendente para promover a liberação das impurezas depositadas na camada do meio filtrante.

\subsubsection{Desinfecção}

Finalmente o tratamento de água é completado com a desinfecção, fluoretação e correção de $\mathrm{pH}$. A desinfecção tem por objetivo a eliminação de organismos patogênicos, tais como bactérias, protozoários e vírus. Na desinfecção podem ser utilizados agentes químicos ou físicos; dentre os químicos, há os oxidantes (cloro, 
bromo, iodo, ozônio, permanganato de potássio e peróxido de hidrogênio) e os íons metálicos (prata e cobre), enquanto os físicos mais utilizados são o calor e a radiação ultravioleta. A desinfecção não destrói todas as formas vivas; o objetivo é a destruição de organismos patogênicos. O cloro (em forma gasosa) e seus derivados, como hipoclorito de cálcio e hipoclorito de sódio, é o produto mais utilizado mundialmente para desinfecção de água nas ETAs, devido ao bom desempenho e baixo custo (HELLER; PÁDUA, 2006).

\subsubsection{Fluoretação e correção de pH}

A fluoretação consiste na adição de flúor na forma de ácido fluorsilícico, fluorsilicato de sódio, fluoreto de sódio ou fluoreto de cálcio (fluorita). O objetivo da aplicação desse produto é a proteção contra a decomposição do esmalte dos dentes. No Brasil, a Portaria n 635/75 do Ministério da Saúde prevê a fluoretação da água potável. Segundo Heller e Pádua (2006), a adição de flúor em águas de abastecimento tem gerado controvérsia entre especialistas devido aos limites aceitáveis para o consumo humano.

Após todas as etapas de tratamento, a água distribuída pode se apresentar corrosiva, o que provoca danos na tubulação de distribuição, como redução da área útil do tubo, aumentando a perda de carga no sistema e diminuindo a vazão. Nas ETAs, a prevenção contra a corrosão geralmente é realizada por um processo de recobrimento interno da tubulação. O tratamento ou condicionamento da água com essa finalidade é feito pela adição de cal ou de carbonato de sódio. Esse tratamento é conhecido como correção de $\mathrm{pH}$. A finalidade é a formação de uma película de carbonato na superfície interna dos tubos, que os protege contra a corrosão. A cal é o produto usualmente empregado, não somente pelo seu baixo custo, como também por razões técnicas (AZEVEDO NETTO, 1966).

Através dessas operações uma ETA produz água potável pronta para o abastecimento de uma população. No entanto, é gerada uma considerável quantidade de resíduos como produto do processo de tratamento: lodo acumulado no fundo dos decantadores e água de lavagem dos filtros. De acordo com Cordeiro (1999), os principais resíduos gerados numa ETA são:

- água de lavagem dos filtros; 
- lodos dos decantadores;

- e rejeito de limpeza dos tanques de produtos químicos.

Segundo Silva e Isaac, 2002, a quantidade de lodo originária dos decantadores representa cerca de 60 a $95 \%$ da quantidade total de resíduos produzidos na ETA, sendo o restante oriundo do processo de filtração. A água de lavagem dos filtros e os lodos dos decantadores são geralmente misturados e destinados conjuntamente.

A NBR 10004 (ABNT, 2004) classifica os lodos gerados nos decantadores de uma ETA como resíduos sólidos classe II B (Inerte), o que obriga a sua disposição sob os critérios da normativa.

\subsection{PRODUÇÃO E QUANTIFICAÇÃO DO LODO DE ETA}

O lodo de ETA é o principal resíduo da produção de água potável a partir de água bruta. Esse resíduo gerado contém baixo teor de sólidos e elevado teor de umidade volumétrico, geralmente acima de $95 \%$, encontrando-se, portanto, em forma de suspensão aquosa (CORDEIRO, 1999). É composto de água e de sólidos suspensos, constituídos de partículas em geral coloidais a finas, acrescidos dos produtos químicos aplicados durante o processo de tratamento, incluindo adição de cloro (desinfecção), sulfato de alumínio e/ou cloreto férrico (coagulação), cal (ajuste de $\mathrm{pH}$ ) e flúor (proteção dos dentes). Os sólidos orgânicos e inorgânicos do lodo, provenientes da água bruta e do processo de tratamento, são algas, bactérias, vírus, partículas orgânicas, coloides, areias, siltes, argilas, cálcio, magnésio, ferro, manganês, além de hidróxidos de alumínio e polímeros. A água bruta de mananciais contaminados pode incluir metais tóxicos e compostos orgânicos persistentes, além de patógenos, como vírus e bactérias (CETESB, 2009).

Nos sistemas de tratamento convencional, a maior parte dos sólidos presentes na água é removida nos decantadores e acumulada no fundo dos mesmos na forma de lodo. Esse lodo se encontra muito diluído, motivo pelo qual precisa ser submetido a algum processo de remoção de água antes de seu transporte e disposição final.

A quantidade e a qualidade do lodo de ETA dependem da frequência de remoção do lodo dos decantadores (GRANDIN; ALEM SOBRINHO; GARCIA Jr, 1993). Richter (2001) complementa que a quantidade de lodo depende, também, da 
qualidade físico-química da água bruta, da qualidade final desejada da água tratada, dos coagulantes e produtos utilizados durante o processo de tratamento, sendo o volume de lodo gerado diretamente proporcional à dosagem de coagulante utilizado no processo.

Luciano et al. (1998) afirmam que este valor representa, em volume, entre 0,3 a 1\% da água tratada. De acordo com Richter (2001), o volume da produção do lodo varia entre $0,2 \%$ e $5 \%$ do volume total de água tratada pela ETA.

Existem diversas formas para realizar a quantificação do lodo gerado no tratamento de água convencional: a determinação da produção de lodo estimada in loco, através do monitoramento dos seus diversos processos e operações unitárias, durante um determinado intervalo de tempo (pelo menos 1 ano); por meio de dados de ETAs que possuam características similares; e através de fórmulas matemáticas empíricas e semiempíricas, as quais são desenvolvidas baseando-se nas características da água bruta e na quantidade de coagulante utilizado.

Algumas das equações mais difundidas e utilizadas são as propostas pela American Water Work Association (AWWA, 1978) apud Januário (2005), pelo Water Research Centre WRC (1979) apud Saron e Leite (2001), e por Cornwell et al. (1987).

A quantidade de lodo em uma ETA segundo a AWWA (1978) pode ser estimada pela seguinte equação:

$$
\mathrm{P}=3,5 \times 10^{-3} * \mathrm{~T}^{0,66}
$$

Onde,

P: $\quad$ produção de sólidos ( $k g$ de matéria seca / $m^{3}$ de água tratada)

T: $\quad$ turbidez da água bruta (UNT)

A equação recomendada pelo WRC (1979) para a estimativa da produção de lodo numa ETA é a seguinte: 


$$
\mathrm{P}=(1,2 * \mathrm{~T}+0,07 * \mathrm{C}+\mathrm{CP} * \mathrm{D}+\mathrm{CA}) * 10^{-3}
$$

Onde,

P: $\quad$ produção de sólidos ( $\mathrm{kg}$ de matéria seca $/ \mathrm{m}^{3}$ de água tratada)

T: $\quad$ turbidez da água bruta (UNT)

C: cor da água bruta (UC)

D: dosagem de coagulante $(\mathrm{mg} / \mathrm{L})$

$\mathrm{CP}$ : coeficiente de precipitação, $k=0,17$ para sulfato de alumínio líquido $k=0,39$ para cloreto férrico líquido

CA: outros aditivos como carvão ativado ou polímeros ( $\mathrm{mg} / \mathrm{L}$ )

Segundo Cornwell et al. (1987), a quantidade de lodo produzido numa ETA, na qual é utilizado cloreto férrico como coagulante, pode ser estimada pela seguinte equação:

$$
\mathrm{P}=\mathrm{Q} *(2,9 * \mathrm{Fe}+\mathrm{SS}+\mathrm{CA})
$$

Onde,

P: $\quad$ produção de sólidos ( $\mathrm{kg} / \mathrm{dia}$ em peso seco)

Q: $\quad$ vazão de água bruta (ML/dia)

Fe: dosagem de cloreto férrico $(\mathrm{mg} / \mathrm{L})$

SS: $\quad$ sólidos em suspensão na água bruta ( $\mathrm{mg} / \mathrm{L})$

CA: outros aditivos como carvão ativado ou polímeros ( $\mathrm{mg} / \mathrm{L}$ )

No caso em que o sulfato de alumínio é o agente coagulante, utiliza-se a equação (2.4): 


$$
\mathrm{P}=\mathrm{Q} *(0,44 * \mathrm{Al}+\mathrm{SS}+\mathrm{CA})
$$

Onde,

\section{Al: $\quad$ dosagem de sulfato de alumínio $(\mathrm{mg} / \mathrm{L})$}

Januário (2005) estimou a produção de sólidos em algumas das principais ETAs da Região Metropolitana de São Paulo (RMSP) pelas fórmulas da AWWA e do WRC, assim como baseando-se em medidas in loco. Os valores obtidos são apresentados na Tabela 2.1. As quantidades de lodo estimadas usando as fórmulas do WRC foram um pouco menores que as calculadas pela formula da AWWA, porém, as estimativas de lodo baseadas em informações da área operacional das ETAs em alguns casos foram próximas das estimativas do WRC e em outros, da AWWA. Não se conclui que uma fórmula seja melhor do que outra para a estimativa da produção de lodo numa ETA da RMSP.

Tabela 2.1 - Estimativa de produção de lodo nas principais ETAs da RMSP.

\begin{tabular}{lcccc}
\hline \multirow{2}{*}{ ETA } & \multirow{2}{*}{$\begin{array}{c}\text { Vazão média } \\
\left(\mathbf{m}^{\mathbf{3}} \mathbf{s}\right)\end{array}$} & WRC & AWWA & $\begin{array}{c}\text { Sólidos em massa seca (t/dia) } \\
\text { Informações da área } \\
\text { operacional da ETA }\end{array}$ \\
\cline { 3 - 5 } & 31,3 & 26,3 & 26,1 & 20,4 \\
Guaraú & 13,5 & 40,5 & 46,6 & 53,6 \\
ABV & 9,6 & 18,2 & 23,7 & 17,9 \\
Taiçupeba & 4,7 & 9,3 & 13,2 & 21,4 \\
Rio Grande & 3,9 & 4,4 & 5,2 & 5,1 \\
Casa Grande & 1,0 & 2,8 & 3,7 & 3,5 \\
Morro Grande & 0,9 & 4,6 & 5,6 & 2,4 \\
Baixo Cotia & & & & \\
\hline
\end{tabular}

Fonte: Januário (2005)

Januário (2005) também estimou a produção de sólidos mês a mês ao longo de um ano, baseando-se nos dados do ano 2003 das ETAs estudadas e na fórmula do WRC. A Figura 2.3 mostra a variação da produção de sólidos média mensal de três ETAs da RMSP. É importante ressaltar a existência de variação na produção de sólidos ao longo do ano. No caso da ETA Taiaçupeba, onde a produção de sólidos menos variou ao longo do ano, a produção média mensal máxima foi de aproximadamente $27.000 \mathrm{~kg} / \mathrm{dia}$ de lodo em massa seca e a mínima ao redor de 
$10.000 \mathrm{~kg} /$ dia, ou seja, a produção máxima foi 2,7 vezes maior do que a mínima, uma diferença consideravelmente alta.

Figura 2.3 - Cálculo da produção média mensal de sólidos em massa seca utilizando a formula do WRC.

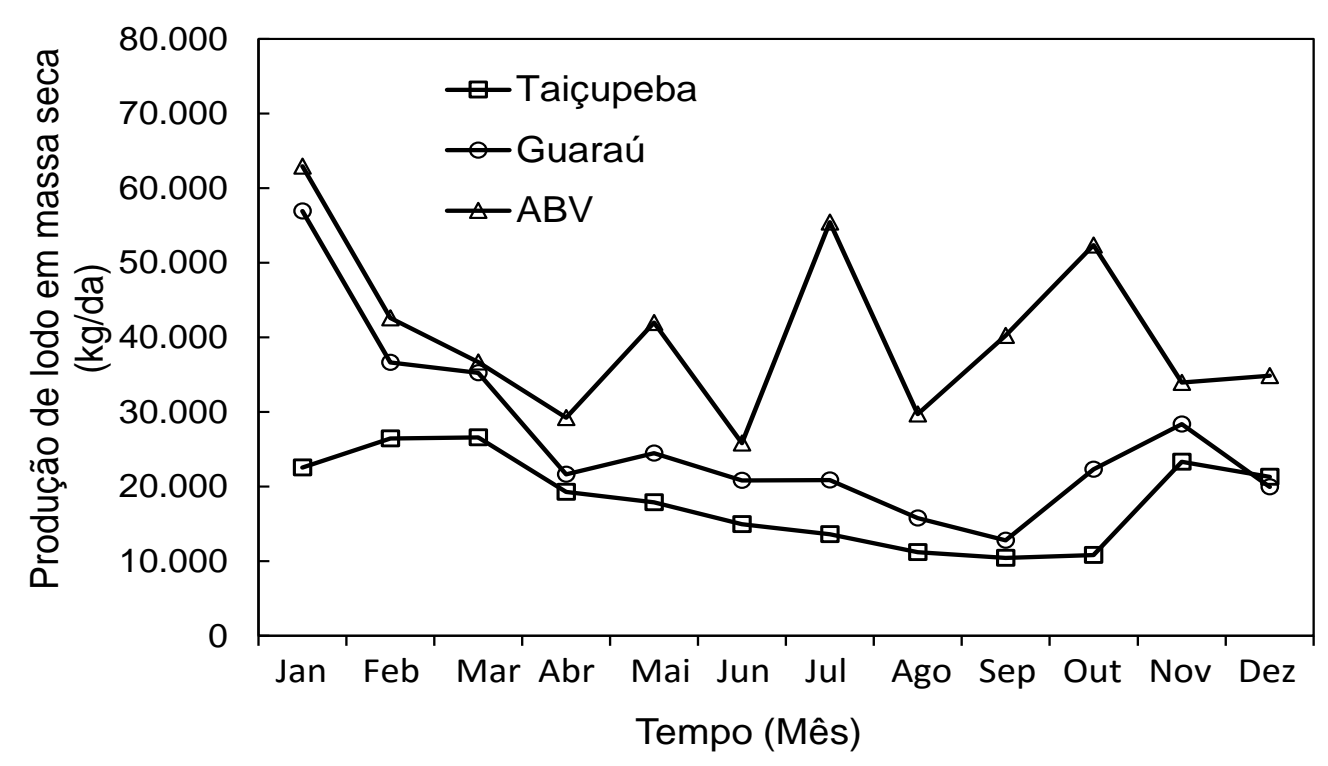

Fonte: adaptado de Januário (2005)

\subsection{DESAGUAMENTO DOS LODOS DE ETAS}

O desaguamento do lodo é a remoção parcial de água do lodo visando à redução do seu volume. Os lodos de ETAs inicialmente encontram-se praticamente em fase líquida, contendo acima de $95 \%$ do seu volume em água, o que inviabiliza seu transporte e disposição final, sendo necessário diminuir a quantidade de água no lodo e aumentar o teor de sólidos. Existem diversos métodos de desaguamento para remover parcialmente a água no lodo, mecânicos e não mecânicos:

- Bolsas geotêxteis;

- Centrífugas;

- Filtros a vácuo;

- Filtros prensa;

- Lagoas de lodo;

- Leitos de secagem;

- Prensa desaguadora. 
Segundo Hsieh e Raghu (1997), dois tipos de métodos de desaguamento são comumente empregados, secagem ao ar e desaguamento mecânico, frequentemente conjugados. Os leitos de drenagem e as lagoas de lodos são os métodos mais comuns de secagem ao ar, já no desaguamento mecânico os dispositivos mais empregados são filtro prensa, filtro prensa de esteira, filtro a vácuo e centrífuga. Ressalte-se que o desaguamento com geotêxteis, ainda pouco empregado, apresenta resultados muito promissores e tende a se tornar mais frequente (SILVEIRA et al., 2015).

O teor de sólidos em lodos de ETAs varia muito com o método de desaguamento empregado. Na Tabela 2.2 são apresentadas as concentrações de sólidos de acordo com o método de desaguamento utilizado e com o tipo de lodo.

Os lodos são chamados de acordo com o produto químico que os originou e que se apresenta numa maior concentração. O lodo de cal (em inglês é utilizado o termo lime sludge) é aquele lodo produzido em ETAs nas quais é utilizada a cal para abrandamento das águas ou para condicionamento químico do lodo visando melhorar as propriedades de desaguamento e aumentar assim o teor de sólidos final. O lodo de coagulante é aquele lodo produto do uso de coagulantes químicos no tratamento da água. Como já mencionado, geralmente são utilizados sais de ferro ou alumínio como agentes coagulantes, e os lodos gerados são chamados respectivamente lodo de ferro (ferric ou iron sludge) e lodo de alumínio (alum sludge). No tratamento de água podem ser utilizados outros produtos químicos para a coagulação, como polímeros, produzindo então o lodo de polímero. Nos dados apresentados na Tabela 2.2 pode-se ver que para o mesmo método de desaguamento o teor de sólidos para lodo de cal é quase o dobro do que para o de coagulante, indicando que a presença de cal melhora significativamente as propriedades de desaguamento dos lodos.

Hsieh e Raghu (1997) avaliaram o desaguamento de lodos de distintas ETAs por três diferentes métodos: mecânico, secagem ao ar e secagem em estufa. $\mathrm{Na}$ Tabela 2.3 são apresentados os teores de sólidos obtidos para lodos de diferentes coagulantes e mediante os diferentes métodos de desaguamento. A quantidade de água removida por método mecânico é muito inferior àquela que pode ser removida por secagem ao ar, mas ainda assim a secagem ao ar dificilmente atingirá valores do 
teor de sólidos maiores do que $88 \%$, devido à água adsorvida e à estrutural (aquela que faz parte da estrutura dos minerais).

Tabela 2.2 - Concentração de sólidos por método de desaguamento.

\begin{tabular}{lcc}
\hline \multirow{2}{*}{ Método de desaguamento } & \multicolumn{2}{c}{ Teor de sólidos (\%) } \\
\cline { 2 - 3 } & Lodo de cal & Lodo de coagulante \\
\hline Adensamento por gravidade & $15-30$ & $3-4$ \\
Centrífuga & $55-65$ & $18-25$ \\
Filtro prensa de esteira & $\mathrm{NE}^{(1)}$ & $15-22$ \\
Prensa de esteira high solids & $\mathrm{NE}^{(1)}$ & $25-30$ \\
Filtro a vácuo & $45-65$ & $\mathrm{NA}^{(2)}$ \\
Filtro-prensa & $55-70$ & $25-45$ \\
Leitos de secagem & 50 & $20-25^{(3)}$ \\
Lagoas de lodo & $50-60$ & $7-15^{(3)}$ \\
\hline
\end{tabular}
(1) $\mathrm{NE}=$ Não estimado
(2) NA = Não aplicável
${ }^{(3)}$ Pode ser muito maior se é utilizado ar na secagem

Fonte: Cornwell (2006)

\section{Tabela 2.3 - Teor de sólidos obtidos mediante diferentes métodos de desaguamento de lodos de ETAs.}

\begin{tabular}{lccc}
\hline \multirow{2}{*}{ Tipo de lodo } & \multicolumn{3}{c}{ Teor de sólidos (\%) } \\
\cline { 2 - 4 } & $\begin{array}{c}\text { Desaguamento } \\
\text { mecânico }\end{array}$ & $\begin{array}{c}\text { Desaguamento por } \\
\text { secagem ao ar }\end{array}$ & $\begin{array}{c}\text { Desaguamento por } \\
\text { secagem em estufa }\end{array}$ \\
\hline Sulfato de alumínio & 30,05 & 83,86 & 100 \\
Sulfato de alumínio & 44,78 & 83,66 & 100 \\
Cloreto férrico & 12,08 & 86,61 & 100 \\
Cal & 22,38 & 88,65 & 100 \\
Sem Cal & 23,82 & 87,78 & 100 \\
\hline
\end{tabular}

Fonte: Hsieh e Raghu (1997)

Os métodos que utilizam a secagem ao ar conseguem teores de sólidos muito maiores que por meios mecânicos, mas existem quatro problemas associados a esses métodos, que são as condições climáticas (chuva e temperatura), o tempo para atingir elevados valores do teor de sólidos, o grande espaço necessário, um problema em zonas urbanas e a necessidade de remexer o lodo, dada a crosta que 
se forma na superfície. Oliveira (2010) reporta o desaguamento de um lodo de ETA por leitos de secagem; após 30 dias de secagem foi atingido um teor de sólidos de 29\%, mas em 20 dos 30 dias houve precipitação.

Hsieh e Raghu (1997) indicam que um menor teor de matéria orgânica melhora as propriedades de desaguamento dos lodos. Os autores estudaram a secagem de diversos lodos, por leitos de secagem e por dispositivos mecânicos, como centrífugas. No caso dos leitos de secagem o desaguamento do lodo não foi muito afetado pela composição do mesmo. Por outro lado, a eficiência no desaguamento dos lodos por meios mecânicos foi condicionada pela composição dos lodos, melhorando com a diminuição da concentração de matéria orgânica.

Dentre os parâmetros considerados não tradicionais necessários para a caracterização do lodo, o tamanho das partículas é de muita importância. A remoção de água livre dos lodos é condicionada pelo tamanho das partículas, o qual está relacionado com a resistência específica, que define a resistência oferecida pelo lodo à passagem de água (o inverso da permeabilidade ou condutividade hidráulica). Os lodos dos decantadores apresentam na sua maioria partículas de pequeno tamanho (fração argila e silte), o que significa um aumento da resistência específica, e quanto maior a resistência específica, menor a capacidade de drenagem de água (CORDEIRO, 1999). Dado que o tamanho das partículas dos lodos varia muito com os produtos químicos empregados no processo de tratamento d'água, também a resistência específica variará.

\subsection{COMPOSIÇÃO MINERALÓGICA DOS LODOS DE ETA}

Como já discutido, os lodos de ETA são compostos por uma variada quantidade de produtos químicos, matéria orgânica e partículas de solo (argila, silte, areia). As partículas de solo presentes nos lodos de ETA são produto do processo de meteorização e erosão das rochas e dos solos. Esse material é transportado por algum corpo de água (rio, lagoa, etc.), do qual a ETA toma a água para potabilizá-la, e daí surgem as grandes quantidades de areia, silte e argila presentes no lodo. Geralmente, as partículas de solo se concentram no lodo numa porcentagem maior que os outros componentes, portanto, o quartzo $\left(\mathrm{SiO}_{2}\right)$ será o mineral presente na maioria dos casos. Na Tabela 2.4 é apresentada a composição mineralógica de lodos 
de várias ETAs, as quais utilizam coagulantes diferentes, obtida mediante difratometria de raios $X(D R X)$.

Tabela 2.4 - Composição mineralógica de lodos de ETAs de distintos países.

\begin{tabular}{|c|c|c|c|c|c|c|}
\hline $\begin{array}{ll}\text { Mineral } & \text { Lodo }\end{array}$ & $\begin{array}{l}\operatorname{Alum}^{(1)} \\
\text { (EUA) }\end{array}$ & $\begin{array}{l}\operatorname{Alum}^{(1)} \\
\text { (EUA) }\end{array}$ & $\begin{array}{l}\operatorname{Alum}^{(1)} \\
\text { (EUA) }\end{array}$ & $\begin{array}{c}\text { Alum (2) }^{(2)} \\
\text { (Portugal) }\end{array}$ & $\begin{array}{l}\text { PAC }^{(3)} \\
\text { (Brazil) }\end{array}$ & $\begin{array}{l}\text { PACL(4) } \\
\text { (Japão) }\end{array}$ \\
\hline Quartzo & $\checkmark$ & $\checkmark$ & $\checkmark$ & $\checkmark$ & $\checkmark$ & $\checkmark$ \\
\hline Grafita & $\checkmark$ & $\checkmark$ & $\checkmark$ & $-\cdots$ & - - & $-\cdots$ \\
\hline Alumina & $\checkmark$ & - - - & $\checkmark$ & - - - & - - - & $-\cdots$ \\
\hline Ringwoodita & - . - & - - - & $\checkmark$ & - . - & - - - & $-\cdots$ \\
\hline Rodocrosita & - . - & - . - & $\checkmark$ & - . - & - . - & $\cdots$ \\
\hline Calcita & - - - & $\checkmark$ & -- & - - - & - - - & - - - \\
\hline Hercinita & - - - & $\checkmark$ & - - & - - - & - - - & -- \\
\hline Caulinita & - . - & - - & - - & - - - & $\checkmark$ & $\checkmark$ \\
\hline Feldspato & - . - & - . - & - & - . - & - - & $\checkmark$ \\
\hline Goethita & - - - & - - &.- & - - & $\checkmark$ & - - - \\
\hline llita & $-\cdots$ & - - - & -- & - - - & $\checkmark$ & -- \\
\hline Magnesita & - . - & - . - & - - & $\checkmark$ & - . - & - - - \\
\hline Gesso & - . - & - - & - & $\checkmark$ & - . - & - - \\
\hline
\end{tabular}

Alum = Sulfato de alumínio

$\mathrm{PAC}=$ Policloreto de alumínio

$\mathrm{PACL}=$ Cloreto de polialumínio

Fonte: adaptado de vários autores (1)Basim (1999), (2) Roque e Carvalho (2006), ${ }^{(3)}$ Teixeira et al. (2011), ${ }^{(4)}$ Watanabe et al. (2011).

\subsection{CARACTERÍSTICAS FÍSICO-QUÍMICAS DOS LODOS DE ETAS}

A caracterização física e química dos lodos de ETA é uma das categorias que são consideradas na avaliação ambiental do resíduo. As principais características físicas e químicas dos lodos de ETAs são o teor de sólidos (orgânicos e inorgânicos), $\mathrm{pH}$, capacidade de troca catiônica (CTC) e composição química (essa última visa principalmente determinar as concentrações de metais).

A determinação do teor de sólidos num lodo leva em conta os sólidos inorgânicos e orgânicos, chamados respectivamente de sólidos fixos e sólidos voláteis. Os sólidos fixos representam a concentração de partículas inorgânicas como argila, silte, areia ou sílica $\left(\mathrm{SiO}_{2}\right)$, os compostos químicos presentes nos coagulantes e os agentes auxiliares adicionados no processo de tratamento da água. 
Hsieh e Raghu (1997) apontam que as concentrações de sólidos orgânicos e inorgânicos contidos nos lodos de ETAs variam dependendo da origem da água bruta, dos produtos químicos adicionados e do método de desaguamento do lodo empregado. Os autores, baseando-se na análise de 10 lodos de diferentes ETAs, indicam que os lodos obtidos de ETAs que utilizam água bruta proveniente de rios apresentam baixas concentrações de sólidos orgânicos e altas concentrações de inorgânicos, variando os sólidos voláteis de 3 a 17 \%. Por outro lado, os lodos de ETAs que utilizam água proveniente de reservatórios ou lagoas apresentam elevadas concentrações de sólidos orgânicos e baixas concentrações de inorgânicos, variando os sólidos voláteis de 14 a $63 \%$.

$\mathrm{O}$ pH dos lodos de ETA é um parâmetro muito importante para a disposição do resíduo, principalmente quando considerada sua utilização na agricultura ou sua disposição em aterros sanitários ou industriais. De acordo com Hsieh e Raghu (1997), o pH é importante porque afeta a lixiviação dos metais e a biodegradação da matéria orgânica. Um pH elevado (meio básico, $\mathrm{pH}>7$ ) favorece a imobilização dos metais e a biodegradação (USEPA, 1986), mas um pH baixo (meio ácido, $\mathrm{pH}<7$ ) permite que os metais possam ser lixiviados. A biodegradação ocorre num $\mathrm{pH}$ próximo do neutro e com condições favoráveis de nutrientes, temperatura e água.

Pesquisas realizadas por diversos autores indicam que o $\mathrm{pH}$ dos lodos de ETA varia com o tipo e quantidade de coagulante utilizado. Em pesquisas realizadas por Hsieh e Raghu (1997), o pH dos lodos de cloreto férrico ou sulfato de alumínio variou de 6,5 a 7,8, e em lodos com uso de cal variou de 6,3 a 11,2. Given e Spink (1984) determinaram valores de $\mathrm{pH}$ para um lodo de alumínio entre 5,5 a 7,5. Outros autores que têm estudado lodos de ETA encontraram valores de $\mathrm{pH}$ compreendidos entre 6,0 e 8,3 (DE CASTILHOS JUNIOR; PRIM; PIMENTEL, 2011; GUERRA, 2005; OLIVEIRA; MACHADO; HOLANDA, 2004; PORTELLA et al., 2003).

A capacidade de troca catiônica (CTC) é uma propriedade físico-química intrínseca dos minerais e da matéria orgânica presentes no solo, a qual indica a capacidade do solo de manter e trocar cátions. A CTC é definida como a soma dos cátions trocáveis expressos em meq/100g (miliequivalentes por $100 \mathrm{~g}$ de material seco) ou cmolc/kg (centimoles de cátions por kg de material seco). Uma CTC baixa indica que o solo tem uma baixa fertilidade e é suscetível a acidificação, enquanto 
uma CTC elevada geralmente denota uma alta capacidade de retenção de contaminantes (HAZELTON; MURPHY, 2007). A CTC média dos solos encontra-se aproximadamente entre 3 e 35 meq/100g (BRADY; WEIL, 2008) e na matéria orgânica varia de 100 a 400 meq/100g (FOTH, 1991). Em lodos de ETA, a CTC está relacionada à composição química e mineralógica. A composição química é principalmente afetada pelo agente coagulante e a composição mineralógica resulta dos minerais que compõem as partículas coloidais presentes no lodo.

Hsieh e Raghu (1997) determinaram a CTC de vários lodos provenientes de ETAs que utilizaram coagulantes diferentes. Os valores de CTC variaram desde um mínimo de 23 até um máximo de $136 \mathrm{meq} / 100 \mathrm{~g}$, valores maiores do que aqueles que são encontrados na maioria dos solos, no entanto, menores que os valores correspondentes à matéria orgânica. Os autores indicaram a existência de uma possível relação entre esses valores de CTC e o teor de matéria orgânica. Algumas características físico-químicas de lodos dos decantadores das ETAs operadas pela SABESP na RMSP são apresentadas na Tabela 2.5. Existe grande variação entre as concentrações de diversos elementos químicos nos lodos dessas ETAs.

Tabela 2.5 - Características físico-químicas dos lodos de decantadores das estações de tratamento de água da região metropolitana de São Paulo.

\begin{tabular}{ccccccc}
\hline & \multicolumn{5}{c}{ ETA } & \multicolumn{5}{c}{ Municípios do Estado de São Paulo } \\
\cline { 2 - 6 } Parâmetro & Guaraú & $\begin{array}{c}\text { Alto da } \\
\text { Boa Vista }\end{array}$ & $\begin{array}{c}\text { Rio } \\
\text { Claro }\end{array}$ & $\begin{array}{c}\text { Rio } \\
\text { Grande }\end{array}$ & $\begin{array}{c}\text { Teodoro } \\
\text { Ramos }\end{array}$ & $\begin{array}{c}\text { Alto } \\
\text { Cotia }\end{array}$ \\
\hline Alumínio $(\mathrm{g} / \mathrm{kg})$ & 65,3 & 7,5 & 6,7 & 83,8 & 123,5 & 95,5 \\
Cobre $(\mathrm{g} / \mathrm{kg})$ & 23,0 & 1,1 & 14,8 & 25,0 & 2,8 & $<5$ \\
Ferro $(\mathrm{g} / \mathrm{kg})$ & 32,7 & 281,5 & 449,8 & 32,7 & 41,3 & 30,1 \\
Fluoreto $(\mathrm{g} / \mathrm{kg})$ & 152,0 & 86,0 & 150,0 & 42,0 & 46,0 & 38,0 \\
Manganês $(\mathrm{g} / \mathrm{kg})$ & 3,1 & 1,7 & 6,7 & 136,0 & 5,2 & 453,0 \\
Sódio $(\mathrm{g} / \mathrm{kg})$ & 6,6 & 1,07 & 41,5 & 563,0 & 3,2 & 433,0 \\
Zinco $(\mathrm{g} / \mathrm{kg})$ & 59,0 & 57,0 & 75,0 & 47,0 & 145,0 & 66,0 \\
Organoclorados $(\mathrm{ppb})$ & - & 0,02 & 0,02 & - & - & - \\
Carbonatos $(\mathrm{ppb})$ & - & 8,4 & - & - & - & - \\
Sólidos totais $(\mathrm{g} / \mathrm{L})$ & 24,9 & 17,4 & 14,5 & 11,0 & 5,5 & 10,7 \\
\hline
\end{tabular}

Fonte: Cordeiro (1999) apud Prim (2011) 
No caso do alumínio e do ferro, as concentrações variam de 7,5 a 123,5 g/kg e de 30,1 a 449,8, respectivamente. Essas diferenças de concentrações são devidas à utilização de coagulantes diferentes nas ETAs, por exemplo, uma elevada concentração de alumínio ou ferro pode estar relacionada ao emprego respectivamente de sulfato de alumínio ou de cloreto férrico como agente coagulante no processo de tratamento de água.

Pode ser visto na Tabela 2.5 que existe muita diferença entre as propriedades e características dos lodos gerados em distintas ETAs, indicando a necessidade de tratar os lodos de cada ETA de forma individualizada.

A Tabela 2.6 mostra os resultados das análises químicas de lodos de ETAs realizadas por diversos autores (SANTOS et al., 2000, OLIVEIRA; MACHADO; HOLANDA, 2004, HOPPEN et al., 2005, TARTARI et al., 2011).

Tabela 2.6 - Composição química de lodos de distintas ETAs.

\begin{tabular}{ccccc}
\hline \multirow{2}{*}{$\begin{array}{c}\text { Composto } \\
\text { químico }\end{array}$} & $\begin{array}{c}\text { ETA São } \\
\text { Leopoldo }\end{array}$ & $\begin{array}{c}\text { ETA Campos dos } \\
\text { Goytacazes }\end{array}$ & ETA Passaúna & $\begin{array}{c}\text { ETA } \\
\text { Tamanduá }\end{array}$ \\
\hline $\mathrm{SiO}_{2}$ & 34,80 & 35,92 & 15,55 & 24,1 \\
$\mathrm{Al}_{2} \mathrm{O}_{3}$ & 22,30 & 31,71 & 13,07 & 31,6 \\
$\mathrm{Fe}_{2} \mathrm{O}_{3}$ & 6,60 & 12,79 & 4,15 & 18,6 \\
$\mathrm{TiO}_{2}$ & 0,94 & 1,10 & 0,19 & 2,2 \\
$\mathrm{MnO}$ & 0,17 & 0,09 & 0,22 & - \\
$\mathrm{MgO}$ & 0,69 & 0,37 & 0,15 & - \\
$\mathrm{CaO}$ & 0,40 & 0,10 & 0,43 & - \\
$\mathrm{K}$ & $0,5 \mathrm{O}$ & 0,58 & 0,06 & 0,3 \\
$\mathrm{Na}{ }_{2} \mathrm{O}$ & 0,23 & 0,06 & 0,04 & - \\
$\mathrm{P}_{2} \mathrm{O}_{5}$ & - & 0,35 & 0,26 & - \\
$\mathrm{SO} \mathrm{N}_{3}$ & - & - & - & - \\
$\mathrm{FeO}$ & 2,90 & - & - & 2,8 \\
$\mathrm{PF}$ & 27,99 & 16,93 & 49,79 & - \\
Outros & - & - & 15,09 & \\
voláteis & & & & \\
\hline $\mathrm{PF}=\mathrm{Perda}$ ao fogo & & &
\end{tabular}

Fonte: adaptado de vários autores, Santos et al. (2000), Oliveira; Machado e Holanda (2004), Hoppen et al. (2005), Tartari et al. (2011) 
Babatunde e Zhao (2007), baseando-se numa extensa quantidade de pesquisas sobre caracterização química de lodos de ETAs, estabeleceram intervalos dos prováveis valores de parâmetros e concentrações de elementos químicos que podem ser encontrados nesses resíduos (Tabela 2.7).

Tabela 2.7 - Composição típica dos lodos de ETAs.

\begin{tabular}{llccc}
\hline \multirow{2}{*}{ Parâmetro } & \multirow{2}{*}{ Unidade } & \multicolumn{3}{c}{ Agente coagulante ou condicionante } \\
\cline { 3 - 5 } & & Sulfato de alumínio & Cloreto férrico & Cal \\
\hline Alumínio & \% peso seco & $29,7 \pm 13,3$ & $10,0 \pm 4,8$ & $0,5 \pm 0,8$ \\
Ferro & \% peso seco & $10,2 \pm 12,0$ & $26,0 \pm 15,5$ & $3,3 \pm 5,8$ \\
Cálcio & \% peso seco & $2,9 \pm 1,7$ & $8,32 \pm 9,5$ & $33,1 \pm 21,1$ \\
Magnésio & \% peso seco & $0,89 \pm 0,80$ & 1,6 & $2,2 \pm 1,04$ \\
Sílica $\left(\mathrm{SiO}_{2)}\right)$ & \% peso seco & $33,4 \pm 26,2$ & - & 54,57 \\
$\mathrm{pH}$ & & $7,0 \pm 1,4$ & $8,0 \pm 1,6$ & $8,9 \pm 1,8$ \\
$\mathrm{DBO}_{5}$ & $\mathrm{mg} / \mathrm{L}$ & $45(2-104)$ & - & - \\
Fósforo & $\%$ peso seco & 0,35 & 0,36 & 0,02 \\
Zinco & $\mathrm{mg} / \mathrm{kg}$ & $33,9 \pm 28,0$ & $18,7 \pm 16,0$ & $2,5 \pm 0,7$ \\
Chumbo & $\mathrm{mg} / \mathrm{kg}$ & $44,1 \pm 38,2$ & $19,3 \pm 25,3$ & $1,87 \pm 0,02$ \\
Cádmio & $\mathrm{mg} / \mathrm{kg}$ & 0,5 & $0,48 \pm 0,26$ & $0,44 \pm 0,02$ \\
Níquel & $\mathrm{mg} / \mathrm{kg}$ & $44,3 \pm 38,4$ & $44,3 \pm 38,4$ & $0,98 \pm 0,52$ \\
Cobre & $\mathrm{mg} / \mathrm{kg}$ & $33,72 \pm 32,5$ & $18,7 \pm 25,8$ & $3,6 \pm 3,1$ \\
Crômio & $\mathrm{mg} / \mathrm{kg}$ & $25,0 \pm 20,1$ & $25,7 \pm 21,6$ & $1,3 \pm 0,2$ \\
Cobalto & $\mathrm{mg} / \mathrm{kg}$ & 1,06 & $1,61 \pm 1,10$ & $0,67 \pm 0,05$ \\
Sólidos totais & $\mathrm{mg} / \mathrm{L}$ & $(2500-52.345)$ & $(2132-5974)$ & - \\
\hline Fonte: Babatund & & & \\
\hline
\end{tabular}

Fonte: Babatunde e Zhao (2007)

Os grandes intervalos apresentados na Tabela 2.7, assim como as variações significativas dos parâmetros observadas nas Tabelas 2.5 e 2.6, são consequência da diferente qualidade da água bruta, do sistema de tratamento da água e do padrão exigido para a água tratada. A maioria dos países têm normativas que regulam a disposição dos lodos de ETAs e exigem uma avaliação ambiental com análises químicas para verificar se os parâmetros e as concentrações de metais definem o material como inerte, não inerte ou perigoso segundo limites estabelecidos pela normativa.

Pesquisas têm sido realizadas para avaliar o impacto ambiental da utilização do lodo de ETA em diversas matrizes, tais como blocos cerâmicos, tijolos, concreto, 
solo-cimento e misturas betuminosas (HOPPEN et al., 2005; LUCENA et al., 2014; MORITA et al., 2002; OLIVEIRA; MACHADO; HOLANDA, 2004; PORTELLA et al., 2003), com resultados promissores, indicando que o lodo de ETA comporta-se como material inerte dentro dessas matrizes.

Roque e Carvalho (2006) estudaram a possibilidade do uso como material geotécnico de um lodo de uma ETA que utiliza sulfato de alumínio como coagulante. Baseando-se na normativa, os autores realizaram análises químicas do lodo e do lixiviado do lodo. No caso do lodo, apenas a diferença entre as perdas ao fogo a $550 \stackrel{\circ}{\circ}$ e $105 \stackrel{\circ}{C}$ encontrou-se acima do valor máximo admissível; os demais parâmetros atenderam aos limites para resíduos inertes. Para o lixiviado, 15 de 19 parâmetros cumpriram com os limites correspondentes a resíduos inertes, em alguns casos apresentando valor muito menor do que o máximo admissível.

\subsection{COMPORTAMENTO GEOTÉCNICO DOS LODOS DE ETAS}

\subsubsection{Caracterização geotécnica}

A massa específica dos grãos de um solo depende principalmente da composição mineralógica. A massa específica dos grãos da maioria dos minerais constituintes dos solos varia de 2,55 a 2,75 g/ $\mathrm{cm}^{3}$, com valor médio de $2,65 \mathrm{~g} / \mathrm{cm}^{3}$. No caso dos lodos de ETAs, de granulometria fina na sua maioria, é tentador pensar que a massa específica dos grãos será muito parecida com aquela dos argilominerais, que varia de 2,70 a $2,85 \mathrm{~g} / \mathrm{cm}^{3}$ e média de $2,77 \mathrm{~g} / \mathrm{cm}^{3}$. Porém, isso não acontece; geralmente os lodos de ETA apresentam valores menores (Tabela 2.8 a 2.10).

A presença de matéria orgânica proveniente da água bruta tratada e os produtos químicos adicionados alteram a massa específica dos grãos dos lodos. Segundo Hsieh e Raghu (1997), um elevado teor de matéria orgânica diminuirá o valor da massa específica dos grãos, enquanto a presença de metais (e.g. ferro, quando utilizado cloreto férrico como coagulante) o incrementará. Basim (1999) estudou o efeito da temperatura de secagem na determinação da massa específica dos grãos de diferentes lodos de ETA. A Figura 2.4 mostra que a massa específica dos grãos aumenta à medida que a temperatura usada na secagem do lodo é maior. Segundo esse autor, dado que a matéria orgânica tanto nos solos orgânicos quanto nos lodos de ETA é responsável pelos baixos valores da massa específica, também é responsável pelo incremento dessa propriedade ao se oxidar quando a temperatura 
de secagem é maior. Por exemplo, o valor da massa específica dos grãos de uma das amostras de lodo (Lodo 2) com 34,5\% de matéria orgânica foi $2,11 \mathrm{~g} / \mathrm{cm}^{3}$ quando seca a $60{ }^{\circ} \mathrm{C}$ e $2,75 \mathrm{~g} / \mathrm{cm}^{3}$ quando seca a $550{ }^{\circ} \mathrm{C}$, o que representa um aumento de $30,3 \%$ devido à temperatura de secagem.

Figura 2.4 - Variação da massa específica dos grãos com a temperatura de secagem do lodo.

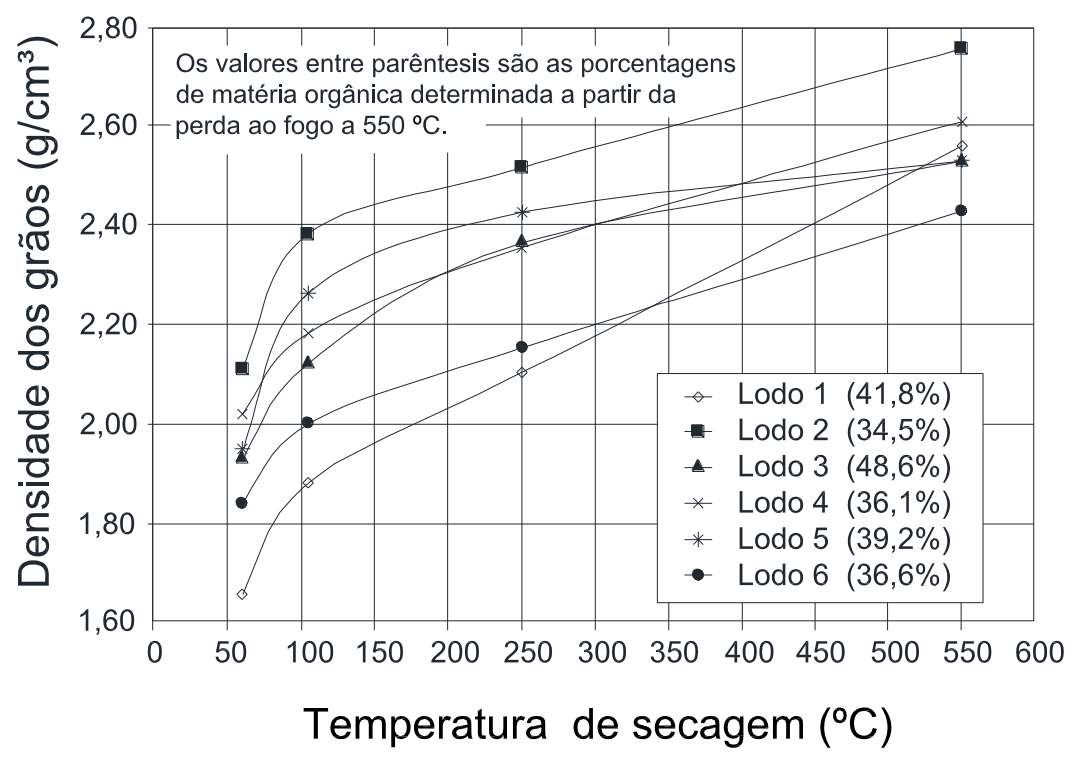

Fonte: Basim (1999)

Tabela 2.8 - Características geotécnicas de lodos de ETAs que utilizam sulfato de alumínio como coagulante.

\begin{tabular}{lcccc}
\hline \multirow{2}{*}{\multicolumn{1}{c}{ ETA }} & \multicolumn{4}{c}{ Características geotécnicas } \\
\cline { 2 - 5 } & $\begin{array}{c}\text { Areia }{ }^{(1)} \\
(\%)\end{array}$ & $\begin{array}{c}\text { Silte }{ }^{(1)} \\
(\%)\end{array}$ & $\begin{array}{c}\text { Argila }{ }^{(1)} \\
(\%)\end{array}$ & $\begin{array}{c}\text { Massa específica } \\
\left.\text { dos grãos (g/cm }^{3}\right)\end{array}$ \\
\hline ETA Harwood's Mill & 40,00 & 45,00 & 15,00 & 2,94 \\
ETA Main Street & 23,20 & 59,90 & 16,90 & 2,51 \\
ETA Lake Chaplin & 26,00 & 48,10 & 25,90 & 2,53 \\
ETA Ipswich & 33,20 & 39,00 & 27,80 & 2,16 \\
ETA Tar River & 19,80 & 8,50 & 71,70 & 2,26 \\
ETA Port Wentworth & 19,30 & 56,90 & 23,80 & 2,25 \\
Eta Lake Kilby & 14,40 & 35,90 & 49,70 & 2,21 \\
ETA E.M. Johnson & 12,50 & 54,40 & 33,10 & 2,07 \\
ETA York & 18,50 & 50,60 & 30,90 & 2,18 \\
ETA Lake Gaillard & 3,00 & 86,00 & 11,00 & 2,05 \\
\hline
\end{tabular}

(1) Classificação da ASTM (American Society for Testing Materials)

Fonte: Vandermeyden e Cornwell (1998) 
Tabela 2.9 - Características geotécnicas de lodos de ETAs que utilizam cloreto férrico como coagulante.

\begin{tabular}{lcccc}
\hline \multirow{2}{*}{ ETA } & \multicolumn{4}{c}{ Características geotécnicas } \\
\cline { 2 - 5 } & $\begin{array}{c}\text { Areia }{ }^{(1)} \\
(\%)\end{array}$ & $\begin{array}{c}\text { Silte } \\
(\%)\end{array}$ & $\begin{array}{c}\text { Argila }{ }^{(1)} \\
(\%)\end{array}$ & $\begin{array}{c}\text { Massa específica dos } \\
\text { grãos }\left(\mathbf{g} / \mathbf{c m}^{3}\right)\end{array}$ \\
\hline ETA Sourdough Canyon & 56,00 & 31,20 & 12,80 & 2,37 \\
ETA 1, Louisville, Ky. & 34,00 & 49,10 & 16,90 & 2,80 \\
ETA 2, Louisville, Ky. & 36,70 & 44,90 & 18,40 & 2,84 \\
ETA Sweetwater Authority & 15,90 & 57,40 & 26,70 & 2,35 \\
ETA Manatee County & 37,30 & 23,10 & 39,60 & 2,44 \\
ETA Baxter & 1,40 & 60,20 & 38,40 & 2,45 \\
ETA Queen Lane & 8,30 & 58,90 & 32,80 & 2,27 \\
ETA Belmont & 12,00 & 69,20 & 18,80 & 2,30 \\
ETA Winchester & 14,00 & 51,00 & 35,00 & 2,08 \\
\hline
\end{tabular}

(1) Classificação da ASTM

Fonte: Vandermeyden e Cornwell (1998)

Tabela 2.10 - Características geotécnicas de lodos de ETAs que utilizam cloreto de polialumínio (PACL) como coagulante.

\begin{tabular}{|c|c|c|c|c|}
\hline \multirow[b]{2}{*}{ ETA } & \multicolumn{4}{|c|}{ Características geotécnicas } \\
\hline & $\begin{array}{c}\text { Areia }^{(1)} \\
(\%)\end{array}$ & $\begin{array}{l}\text { Silte }^{(1)} \\
(\%)\end{array}$ & $\begin{array}{l}\operatorname{Argila}^{(1)} \\
(\%)\end{array}$ & $\begin{array}{l}\text { Massa específica } \\
\text { dos grãos }\left(\mathrm{g} / \mathrm{cm}^{3}\right)\end{array}$ \\
\hline ETA St. Bernard Parish & 9,00 & 76,60 & 14,40 & 2,53 \\
\hline ETA Frostburg & 31,30 & 55,00 & 13,70 & 2,22 \\
\hline ETA Roxboro & 0,70 & 45,50 & 53,80 & 2,26 \\
\hline $\begin{array}{l}\text { ETA Blacksburg- } \\
\text { Christiansburg }\end{array}$ & 7,00 & 88,00 & 5,00 & 2,08 \\
\hline ETA Albany & 14,50 & 61,50 & 24,00 & 2,56 \\
\hline
\end{tabular}

(1) Classificação da ASTM

Fonte: Vandermeyden e Cornwell (1998)

Watanabe et al. (2011) estudaram o lodo de uma ETA localizada em Hitachi no Japão, onde é utilizado cloreto de polialumínio (PACL) como agente coagulante. Os autores mostram que várias características físicas do lodo variam sazonalmente, isto é, ao longo das diferentes estações climáticas do ano. Os valores dessas 
características para distintas amostras extraídas em diferentes estações do ano são mostrados na Tabela 2.11. Essas variações são devidas à grande variabilidade da qualidade da água bruta tratada.

Foram identificadas variações na massa específica dos grãos do lodo, de 2,41 a 2,60 g/ $\mathrm{cm}^{3}$; na perda de massa ao fogo, de 9,0 a 26,1\%; e também no limite de liquidez, de 83 a 511\%. Os autores sugerem que a variabilidade nos limites de consistência é devida à variação na concentração de cloreto de polialumínio e no teor de matéria orgânica entre as amostras estudadas.

\section{Tabela 2.11 - Características físicas e geotécnicas de lodo de ETA}

(Hitachi, Japão).

\begin{tabular}{|c|c|c|c|c|c|c|c|c|c|c|}
\hline Amostra & A & B & C & D & $\mathbf{E}$ & $\mathbf{F}$ & $\mathbf{G}$ & $\mathbf{H}$ & $\mathbf{I}$ & $\mathbf{J}$ \\
\hline Data & $\begin{array}{c}\text { Feb } \\
200 \\
6\end{array}$ & $\begin{array}{l}\text { Abr } \\
2006\end{array}$ & $\begin{array}{l}\text { Nov } \\
2006\end{array}$ & $\begin{array}{l}\text { Jun } \\
2007\end{array}$ & $\begin{array}{l}\text { Set } \\
2007\end{array}$ & $\begin{array}{l}\text { Nov } \\
2007\end{array}$ & $\begin{array}{l}\text { Nov } \\
2007\end{array}$ & $\begin{array}{l}\text { Dez } \\
207\end{array}$ & $\begin{array}{l}\text { Jun } \\
2008\end{array}$ & $\begin{array}{l}\text { Nov } \\
2008\end{array}$ \\
\hline $\begin{array}{l}\text { Massa específica } \\
\text { dos grãos }\left(\mathrm{g} / \mathrm{cm}^{3}\right)\end{array}$ & 2,48 & 2,51 & 2,60 & 2,40 & 2,61 & 2,45 & 2,51 & 2,45 & 2,58 & 2,58 \\
\hline $\begin{array}{l}\text { Limite de liquidez } \\
\qquad(\%)\end{array}$ & 330 & 275 & 420 & 248 & 178 & 116 & 221 & 511 & 83 & 224 \\
\hline $\begin{array}{c}\text { Limite de } \\
\text { plasticidade (\%) }\end{array}$ & 167 & 140 & 166 & 165 & 104 & 69 & 145 & 186 & 60 & 145 \\
\hline $\begin{array}{l}\text { Índice de } \\
\text { plasticidade }\end{array}$ & 163 & 135 & 243 & 83 & 74 & 47 & 77 & 325 & 23 & 80 \\
\hline Perda ao fogo (\%) & 25,9 & 26,1 & 25,8 & 18,2 & 17,2 & 12,4 & 18,2 & 17,0 & 9,0 & 22,3 \\
\hline
\end{tabular}

Fonte: Watanabe et al. (2011)

A distribuição granulométrica dos lodos de ETAs depende de uma série de fatores, por exemplo, a estação climática no momento da amostragem, o coagulante utilizado na ETA e a umidade inicial da amostra no ensaio de análise granulométrica.

Teixeira et al. (2011), em um estudo sobre a adição de lodo de policloreto de alumínio à argila na fabricação de produtos cerâmicos, investigaram a granulometria de amostras durante um ano. O estudo mostra como as concentrações das frações areia, silte e argila, assim como também o teor de matéria orgânica, variam nos distintos meses de coleta das amostras (ver Figura 2.5). 
Figura 2.5 - Variação da granulometria e da concentração de matéria orgânica ao longo dos meses de coleta do lodo da ETA

Presidente Prudente, SP, Brasil.

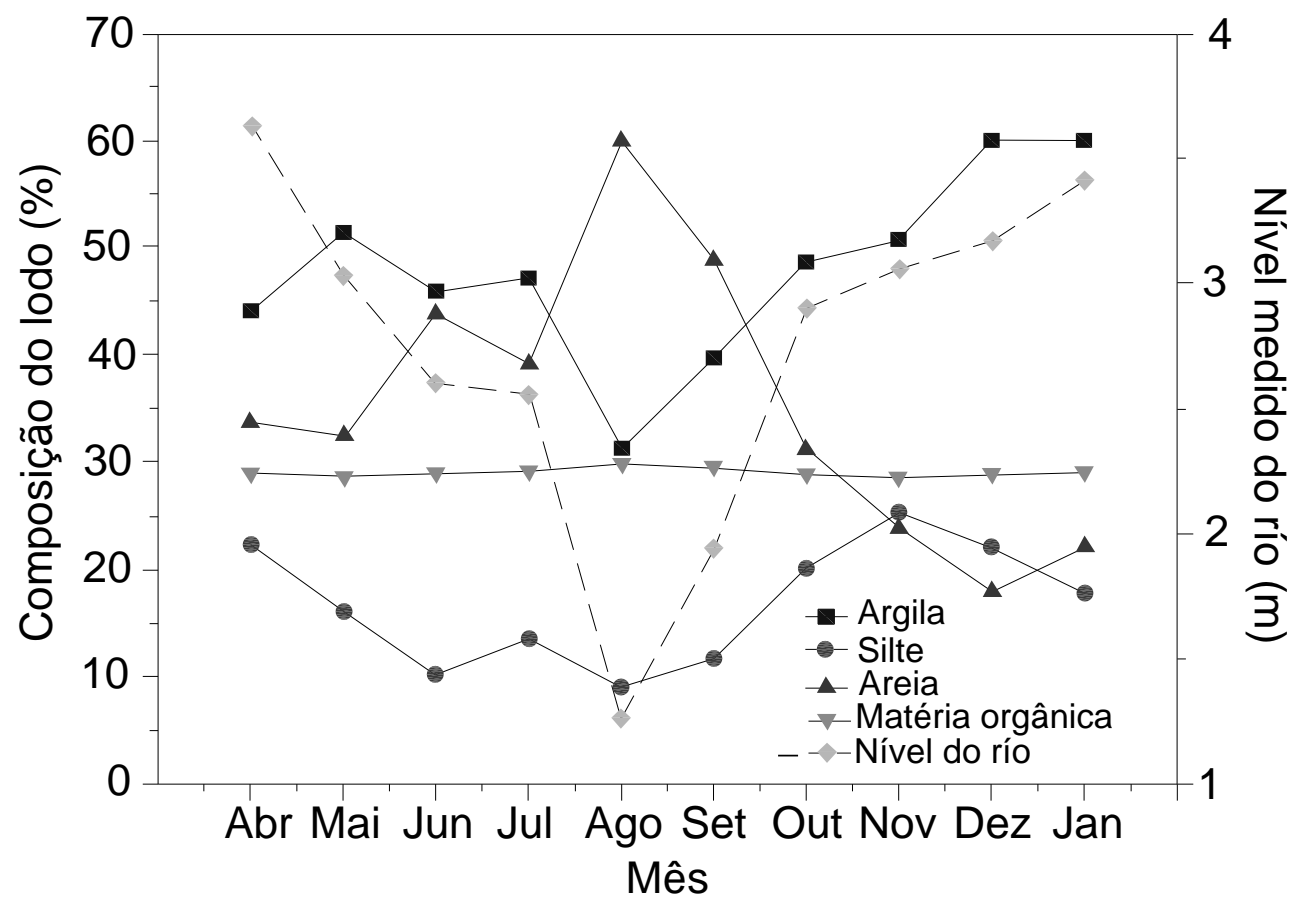

Fonte: adaptado de Teixeira et al. (2011)

Vandermeyden e Cornwell (1998) determinaram a granulometria de 4 lodos diferentes pelo método do hidrômetro. Os lodos foram extraídos de ETAs que utilizam cal, cloreto férrico, sulfato de alumínio e cloreto de polialumínio como agentes coagulantes. As curvas granulométricas obtidas pelos autores são apresentadas na Figura 2.6.

A granulometria dos lodos de ETAs, além de variar com a época de amostragem do lodo e com o agente coagulante empregado no processo de tratamento da água bruta, também varia com a umidade inicial da amostra no momento do ensaio. 
Figura 2.6 - Curvas granulométricas de lodos de ETAs que utilizam coagulantes diferentes.

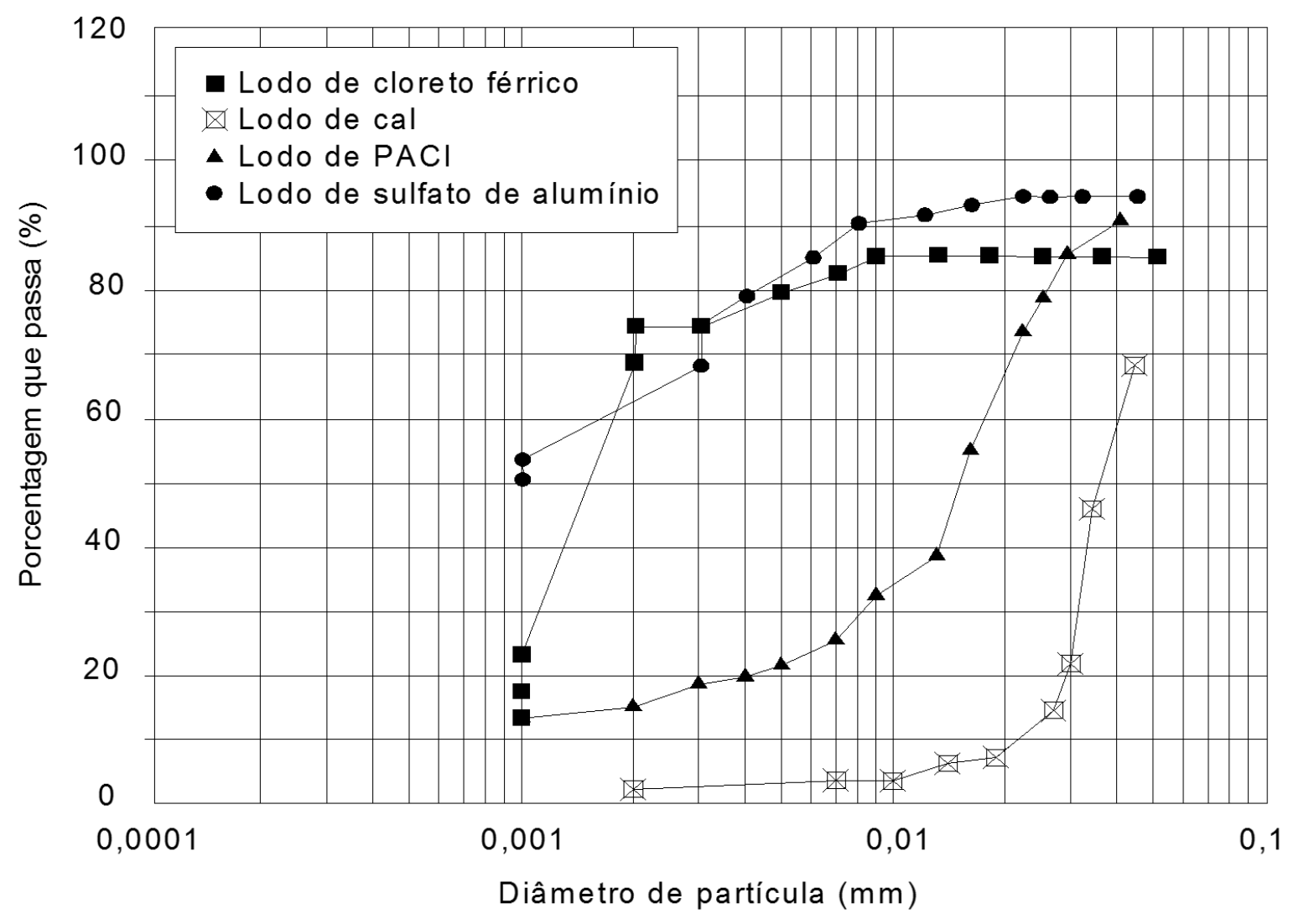

Fonte: Vandermeyden e Cornwell (1998)

Watanabe et al. (2011) mostraram que a distribuição granulométrica de um lodo de ETA depende da umidade inicial, ou seja, a umidade na qual se encontra o lodo no momento de execução do ensaio. Na Figura 2.7 mostram-se as curvas granulométricas para distintas umidades iniciais do lodo; à medida que a umidade inicial diminui, o material tende a se tornar mais granular.

É importante considerar que com a secagem do lodo pode acontecer cimentação das partículas devido à presença dos metais adicionados como coagulantes no tratamento da água. 
Figura 2.7 - Curvas granulométricas de lodo de ETA (Hitachi, Japão).

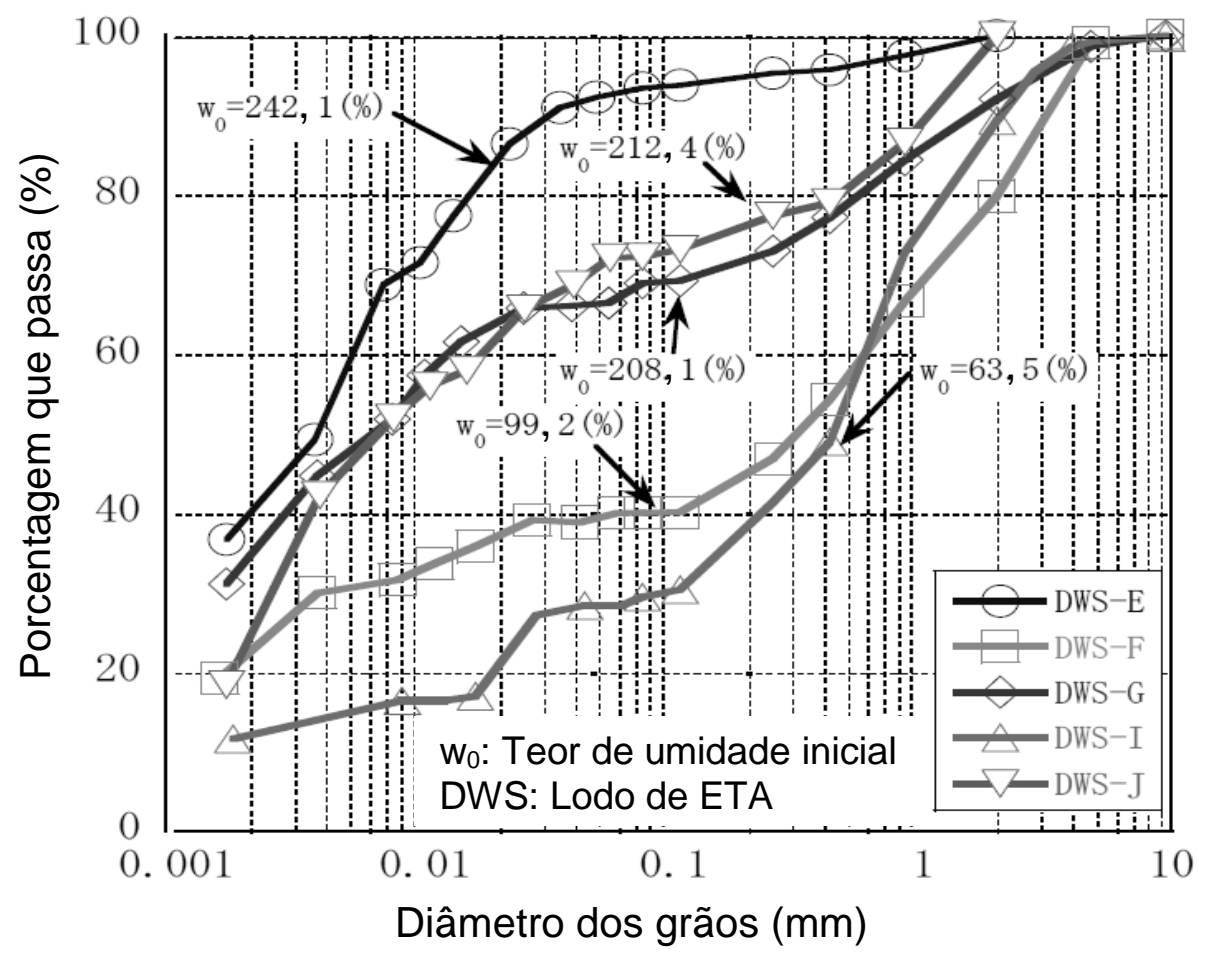

Fonte: Watanabe et al. (2011)

Hsieh e Raghu (1997) realizaram ensaios de distribuição granulométrica pelo método do hidrômetro com 10 lodos de ETAs diferentes. Os ensaios foram executados preparando duas amostras de cada lodo, uma seca em estufa a $105^{\circ} \mathrm{C}$, como estabelecido pela ASTM, e outra na umidade in natura, sem secagem prévia. Embora tenham sido utilizadas distintas porcentagens de defloculante (hexametafosfato de sódio) para neutralizar as cargas na superfície das partículas e separá-las evitando que ocorresse a floculação, os autores consideraram que o ensaio não teve sucesso. No caso da amostra seca, as partículas sofreram cimentação durante a secagem e o defloculante não conseguiu separá-las, consequentemente as partículas sedimentavam-se rapidamente. Para o caso do lodo in natura, o defloculante também não foi efetivo; aconteceu uma refloculação e as partículas não sedimentaram conforme a lei de Stokes. De acordo com os resultados obtidos nos ensaios, Hsieh e Raghu (1997) concluíram que os métodos de peneiramento e sedimentação (método do hidrômetro) não são apropriados para determinar a granulometria de lodos de ETAs. 
Watanabe et al. (2011) determinaram os limites de consistência de um lodo de ETA realizados com amostras coletadas em diferentes datas (Tabela 2.11), os quais apresentaram variações consideráveis ao longo de tempo devido à variabilidade da concentração de coagulante e matéria orgânica nas distintas amostras.

Basim (1999) determinou os limites de consistência de vários lodos de ETA para duas diferentes condições de umidade, uma amostra in natura e outra com secagem prévia. Os resultados obtidos encontram-se na Tabela 2.12. As amostras ensaiadas in natura apresentaram-se como muito plásticas, no entanto, aquelas que foram secas previamente ao ensaio apresentaram-se na sua maioria como não plásticas. Esse resultado está de acordo com aqueles obtidos para a granulometria, a qual também é muito afetada pela secagem prévia. Segundo Basim (1999), uma possível explicação para o fato de que os lodos altamente plásticos in natura se transformam em não plásticos com secagem prévia é a perda da camada dupla e a consequente cimentação das partículas, o que leva à formação de partículas de maior tamanho e, em consequência, a um comportamento de solo granular.

Tabela 2.12 - Limites de consistência de diferentes lodos de ETA.

\begin{tabular}{ccccccc}
\hline $\begin{array}{c}\text { Tipo de } \\
\text { lodo }\end{array}$ & \multicolumn{2}{c}{$\begin{array}{c}\text { Limite de liquidez } \\
\text { (\%) }\end{array}$} & \multicolumn{2}{c}{$\begin{array}{c}\text { Limite de plasticidade } \\
\text { (\%) }\end{array}$} & \multicolumn{2}{c}{$\begin{array}{c}\text { Índice de plasticidade } \\
\text { (\%) }\end{array}$} \\
\cline { 2 - 7 } & In natura & $\begin{array}{c}\text { Secagem } \\
\text { prévia }\end{array}$ & In natura & $\begin{array}{c}\text { Secagem } \\
\text { prévia }\end{array}$ & In natura & $\begin{array}{c}\text { Secagem } \\
\text { prévia }\end{array}$ \\
\hline Alumínio & 371 & 107 & 228 & NP & 144 & NP \\
Cal & 329 & 37 & 200 & NP & 129 & NP \\
Ferro & 690 & 151 & 20 & NP & 670 & NP \\
Cal & 330 & 125 & 212 & 43 & 118 & 82 \\
Polímero & 161 & 55 & 57 & 49 & 104 & 6 \\
Alumínio & 206 & 118 & 115 & NP & 91 & NP \\
\hline NP= Não Plástico & & & & & & \\
Fonte: Basim (1999) &
\end{tabular}

\subsubsection{Parâmetros de compactação}

O ensaio de compactação consiste na aplicação de uma energia mecânica a um solo, visando diminuir os vazios com ar e incrementar a densidade seca do material. Variando a umidade do material ou o teor de sólidos, é possível determinar 
seus parâmetros de compactação, a densidade máxima seca e o teor de umidade ótimo (ou teor de sólidos ótimo). O ensaio de compactação pode ser realizado com secagem prévia do material (ramo seco) ou sem secagem prévia (ramo úmido). A ASTM D0698-00ae1 prescreve a realização do ensaio de compactação sem secagem prévia, enquanto a ABNT NBR-7182 prescreve secagem prévia do material até a umidade higroscópica. Para grande parte dos solos naturais não existe diferença significativa entre os parâmetros de compactação determinados com ou sem secagem prévia do material. No entanto, alguns solos apresentam maior densidade seca máxima e menor teor de umidade ótima quando ensaiados com secagem prévia do que sem secagem. Isso pode acontecer pela perda irreversível de água estrutural dos argilominerais ou por cimentação das partículas provocada pela secagem.

Ainda não existem normas que definam a metodologia para ensaiar os lodos de ETA. Ainda assim, diversos autores têm estudado os parâmetros de compactação de lodos de ETAs utilizando procedimentos preconizados para solos (CORNWELL et al., 1992; WANG et al., 1992; XIA, 1994; HSIEH; RAGHU, 1997; BASIM, 1999; ROQUE; CARVALHO, 2006; O'KELLY, 2008; RODRIGUEZ et al., 2011).

Xia (1994) estudou os parâmetros de compactação de 11 diferentes lodos de ETA na energia normal (Proctor Normal). Foram preparadas duas amostras de cada lodo, uma com secagem prévia e outra sem secagem prévia. No primeiro caso o material foi seco ao ar até a umidade higroscópica e acrescentou-se água ao longo do ensaio para aumentar a umidade (via seca). No segundo caso, o lodo foi seco até uma umidade na qual foi possível começar a compactar o material e continuou-se a secagem ao longo do ensaio para diminuir a umidade (via úmida), obtendo-se assim as curvas de compactação para as duas amostras de cada lodo.

As curvas de compactação para as amostras de lodo obtidas via seca mostraram um formato parabólico, semelhantes às dos solos (Figura 2.8). Os valores da massa específica seca máxima e do teor de sólidos ótimo determinados variaram num intervalo de 0,540 a 1,454 g/cm ${ }^{3}$ e 50 a $80 \%$ (100 a 25\% de teor de umidade), respectivamente. Os lodos ensaiados mostraram um comportamento de solo granular não plástico. Rodríguez et al. (2011) também observaram um comportamento de solo granular ao estudar os parâmetros de compactação de um lodo de ETA, previamente 
desaguado em leitos de secagem até uma umidade abaixo de $15 \%$, obtendo um valor médio de $1,340 \mathrm{~g} / \mathrm{cm}^{3}$ para a massa específica seca máxima e de $73 \%$ (teor de umidade de 37\%) para o teor de sólidos ótimo. Esses valores encontram-se dentro do intervalo determinado para os lodos estudados por Xia (1994).

Figura 2.8 - Curvas de compactação de lodos ETA com secagem prévia.

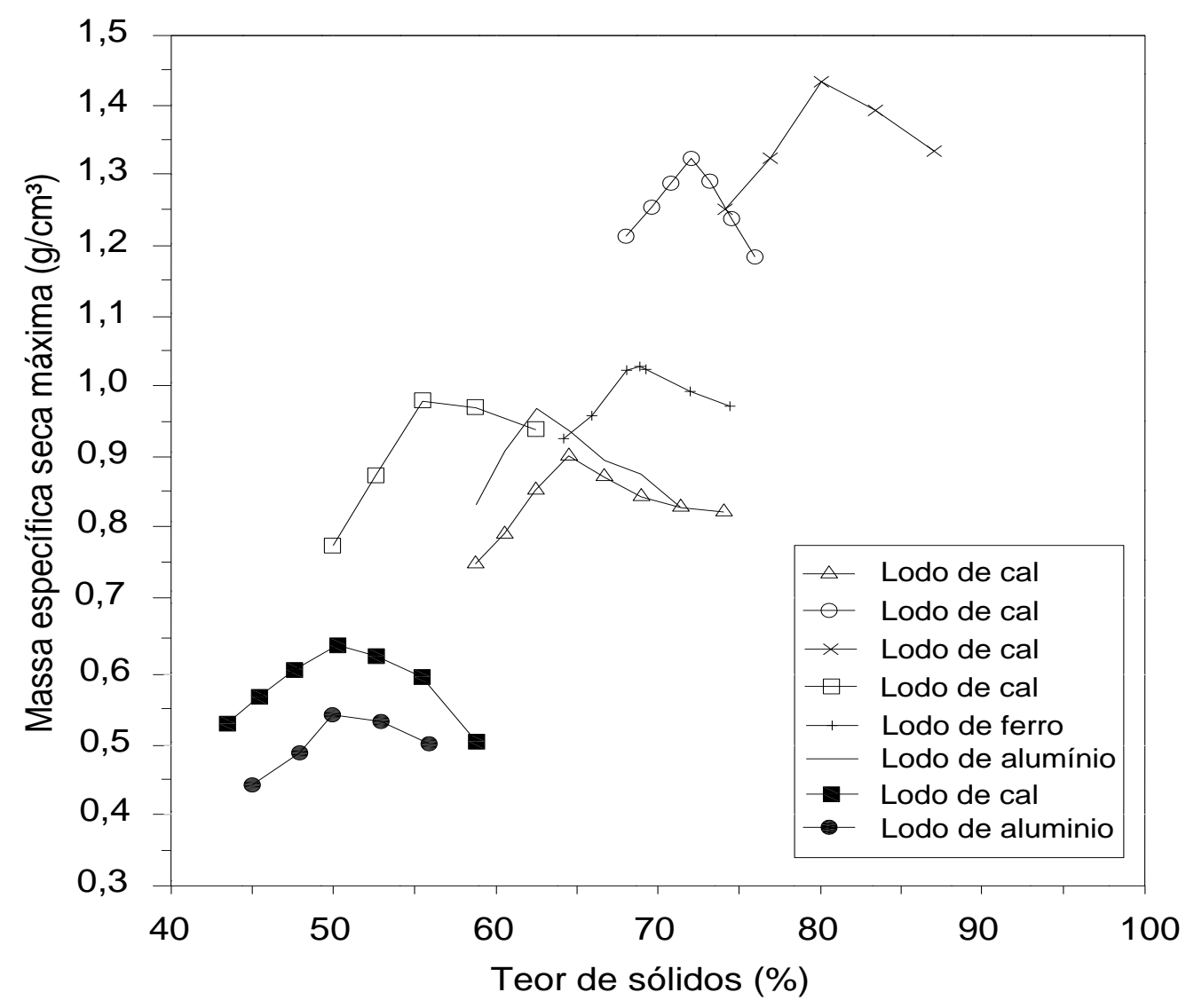

Fonte: adaptado de Xia (1994)

Algumas curvas de compactação das amostras de lodo obtidas via úmida mostraram formato parabólico, enquanto para outras não foi possível definir os parâmetros de compactação por apresentarem uma tendência incremental da massa específica seca em função do teor de umidade de moldagem (Figura 2.9).

Uma relação incremental desse tipo entre os parâmetros de compactação é raramente observada em solos normais (HSIEH; RAGHU, 1997), mas tem sido reportado por outros autores no caso de lodo não submetido a secagem prévia (CORNWELL et al., 1992; WANG et al., 1992). Segundo Xia (1994), esse fenômeno pode ser atribuído à estrutura dos flocos de lodo e a ocorrência de cimentação das 
partículas devida à perda de água. Durante a secagem, a água é removida dos flocos, as ligações entre as faces dos flocos são gradualmente perdidas e os espaços entre os poros colapsam. Logo, os flocos são mantidos juntos para formar uma nova

Figura 2.9 - Curvas de compactação de lodos de ETA sem secagem prévia.

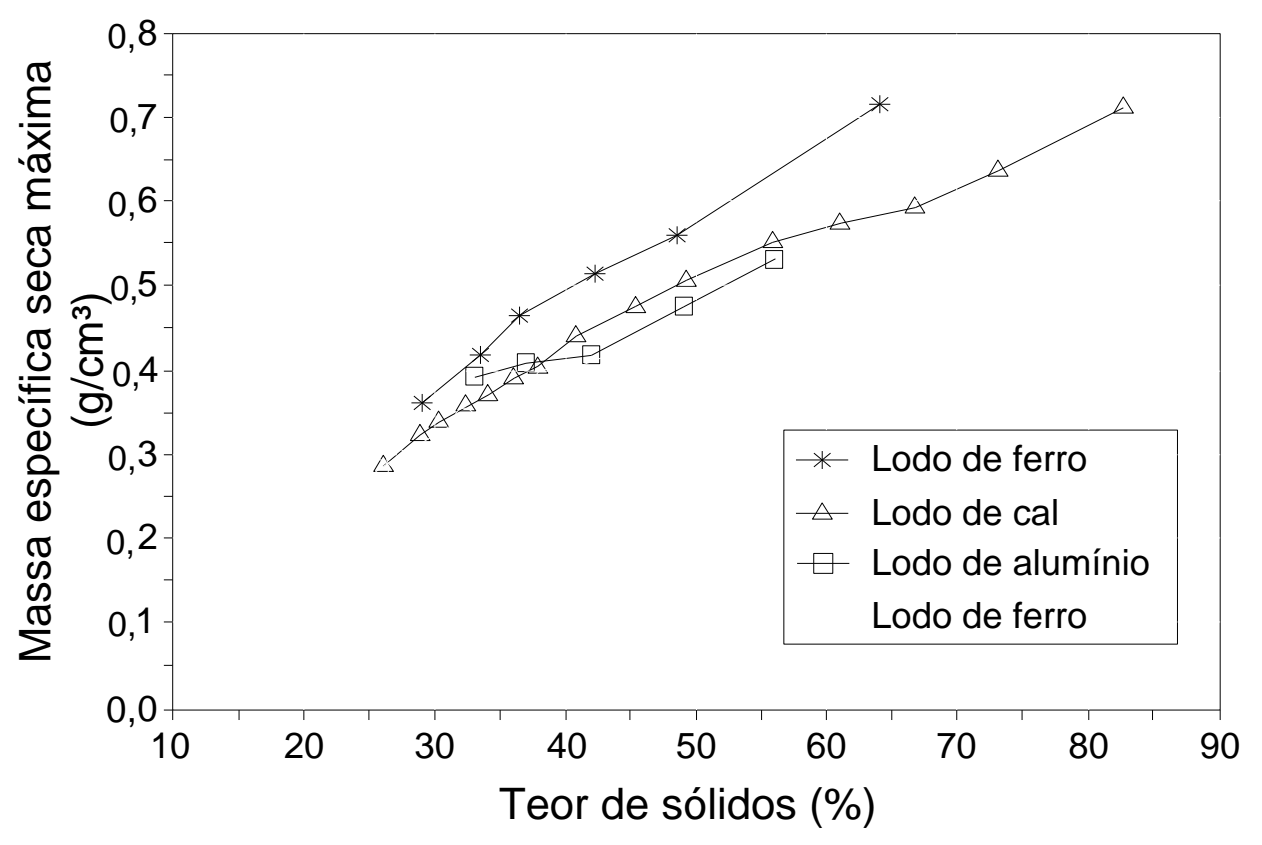

Fonte: adaptado de Xia (1994)

ligação entre partículas. Finalmente a estrutura do floco é destruída enquanto o tamanho das partículas aumenta formando um material arenoso seco.

Os parâmetros de compactação das curvas obtidas por via úmida e que apresentaram formato parabólico variaram de 0,582 a 1,429 g/ $/ \mathrm{cm}^{3}$ no caso da massa específica seca máxima, e de 57,1 a $83,0 \%$ no caso do teor de sólidos ótimo (teor de umidade de 75,1 a $20,5 \%$ ).

De acordo com os resultados dos ensaios de compactação apresentados por Xia (1994) é possível observar que os lodos apresentaram diferentes parâmetros de compactação quando ensaiados por via seca ou por via úmida, sendo a massa específica seca máxima maior e o teor de sólidos ótimo menor no primeiro caso em relação ao segundo. 


\subsubsection{Compressibilidade}

Wang et al. (1992) estudaram a compressibilidade de três lodos de ETAs diferentes, dois lodos de alumínio e um lodo de ferro, por meio de ensaios de adensamento oedométrico. A Figura 2.10 mostra as curvas do índice de vazios em função da tensão vertical efetiva para cada lodo, indicadas como lodo 1 (lodo de ferro), 2 e 3 (lodos de alumínio).

Os índices de compressão $\left(\mathrm{C}_{c}\right)$ respectivos foram 1,99, 6,69 e 5,29. O índice de compressão da maioria das argilas naturais é menor que 1 (WANG et al., 1992). O valor do $\mathrm{C}_{c}$ no caso dos principais argilo-mineriais encontra-se na ordem de 0,19 a 0,28 para a caulinita, de 0,50 a 1,10 para a ilita, e de 1,0 a 2,6 para a montmorilonita (MITCHELL; SOGA, 2005). Os lodos 2 e 3 apresentaram valores de $\mathrm{C}_{c}$ muito superiores do que aqueles da montmorilonita, que é o argilomineral mais compressível. Pode-se observar que os lodos de ETA se apresentam muito mais compressíveis que as argilas naturais. O lodo de ferro mostrou-se menos compressível que os lodos de alumínio, mas é necessário ter mais dados para poder estabelecer uma relação entre a compressibilidade do lodo e o coagulante empregado.

Figura 2.10 - Curvas de adensamento de diferentes lodos de ETA.

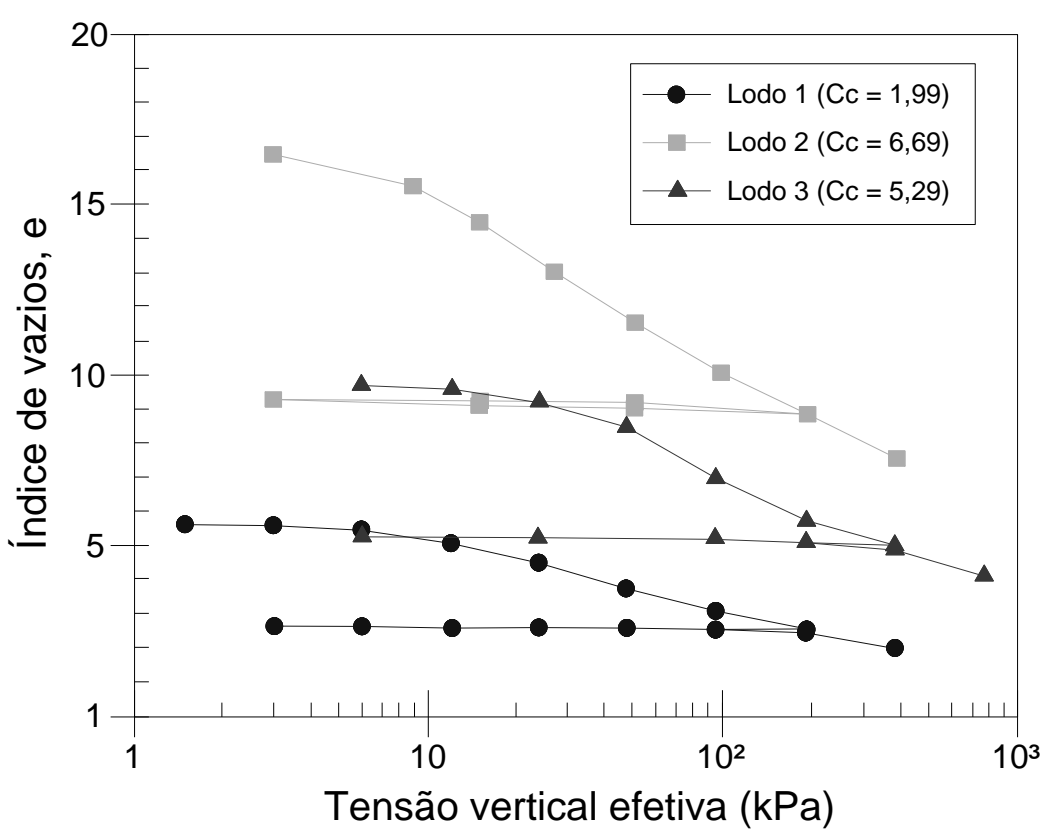

Fonte: adaptado de Wang et al. (1992) 
Wang et al. (1992) correlacionaram o índice de compressão (Cc) com o limite de liquidez (LL) dos lodos de ETA ensaiados, estabelecendo a seguinte equação:

$$
C c=0,9+0,0105 *(L L)
$$

Os índices de recompressão $\left(\mathrm{C}_{\mathrm{r}}\right)$ determinados dos lodos 1, 2 e 3 foram 0,03, 0,17 e 0,15 respectivamente. Esses valores são relativamente baixos considerandose os elevados valores de C. Segundo Mitchell e Soga (2005), os valores de Cr para solos naturais normalmente são menores que 0,1 para solos não expansivos e maiores que 0,2 para solos expansivos.

Aydilek, Edil e Fox (1999) estudaram a compressibilidade de um lodo de ETA por meio de ensaios de adensamento oedométrico convencional (pequena escala) e em consolidômetro (grande escala). O lodo estudado foi retirado de lagoas de secagem, com uma umidade média de 305\% e teor de sólidos de aproximadamente $25 \%$. De acordo com os ensaios de caracterização, o lodo era não plástico.

Os autores comentaram que em ensaios preliminares foi observado que o lodo gerava certa quantidade de gás, o que interferia e às vezes impedia o processo de adensamento no consolidômetro, devido ao longo tempo de ensaio (ao redor de 1000 horas), o que não foi evidenciado no ensaio convencional, possivelmente devido ao pequeno tamanho da amostra e ao menor tempo de ensaio. Para resolver o problema da geração de gás no ensaio realizado no consolidômetro foi aplicada uma contrapressão de $345 \mathrm{kPa}$ durante o ensaio.

Foram ensaiadas três amostras de lodo no consolidômetro, duas adensadas sob tensão vertical de 9,65 kPa e uma sob tensão vertical inicial de 15,2 kPa e final de $123 \mathrm{kPa}$ com uma razão de incremento de carga de 1. Foi determinado um valor médio do índice de compressão de 1,4.

No ensaio convencional oedométrico foram ensaiadas quatro amostras de lodo, obtidas a partir das amostras ensaiadas previamente no consolidômetro. A Figura 2.11 mostra as curvas de adensamento obtidas para as quatro amostras ensaiadas, as quais tinham índice de vazios iniciais diferentes. 
Figura 2.11 - Curvas de adensamento de distintas amostras de um lodo de ETA.

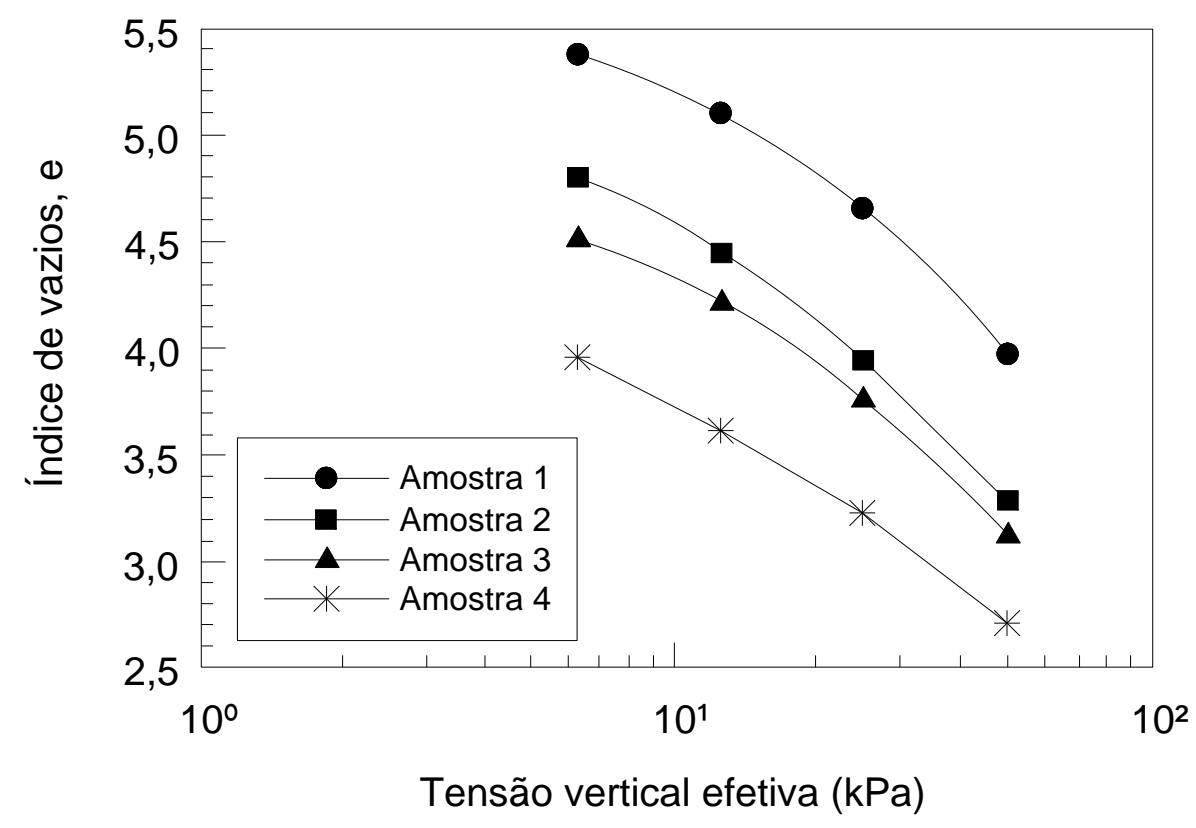

Fonte: Adaptado de Aydilek, Edil e Fox (1999)

O valor do índice de compressão encontrado nas quatro amostras variou num intervalo de 1 a 2. O lodo de ferro estudado por Wang et al. (1992) apresentou um comportamento semelhante à amostra 1, com índice de compressão de 1,99 e índice de vazios inicial ao redor de 5 (Figura 2.11).

Aydilek, Edil e Fox (1999) também determinaram os valores do coeficiente de adensamento $\left(\mathrm{C}_{\mathrm{v}}\right)$ para as amostras ensaiadas no oedômetro, os quais variaram de $5,1 \times 10^{-8}$ a $1,7 \times 10^{-6} \mathrm{~m}^{2} / \mathrm{s}$ para o nível de tensões ensaiado. Esses valores de $\mathrm{C}_{\mathrm{v}}$ indicam que o lodo de ETA tem uma velocidade de adensamento muito baixa. A montmorilonita, a ilita e a caulinita apresentam valores de $\mathrm{C}_{\mathrm{v}}$ respectivamente de: $0,06 \times 10^{-8}$ a $0,3 \times 10^{-8} \mathrm{~m}^{2} / \mathrm{s}, 0,3 \times 10^{-8}$ a $2,4 \times 10^{-8} \mathrm{~m}^{2} / \mathrm{s}, 12 \times 10^{-8}$ a $90 \times 10^{-8} \mathrm{~m}^{2} / \mathrm{s}$ (MITCHELL; SOGA, 2005). Ainda com a finalidade de ilustração, os solos moles da Baixada Santista apresentam valores de $\mathrm{Cv}$ determinados em laboratório variando entre $0,3 \times 0^{-8}$ e $400 \times 10^{-8} \mathrm{~m}^{2} / \mathrm{s}$ (MASSAD, 1999).

O'Kelly (2008) estudou o adensamento de um lodo de ETA por meio de ensaios realizados em três diferentes equipamentos, célula edométrica, consolidômetro e câmara triaxial. Na Figura 2.12 são apresentadas as curvas de adensamento obtidas nos ensaios realizados na célula edométrica e no 
consolidômetro; no primeiro foi aplicado um nível de tensões de 3 a $800 \mathrm{kPa}$, e no segundo, de 10 a $30 \mathrm{kPa}$.

Figura 2.12 - Curvas de adensamento de um lodo de ETA ensaiado em célula edométrica e em consolidômetro.

16

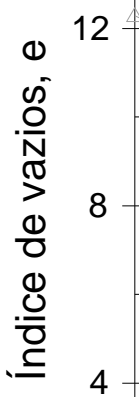

Amostra $\mathrm{F}$ (Célula edométrica)

Amostra $E$ (Célula edométrica)

Amostra G (Consolidômetro)

1

1

10

$10^{2}$

$10^{3}$

Tensão vertical efetiva $(\mathrm{kPa})$

Fonte: adaptado de O’Kelly (2008)

A partir das curvas da Figura 2.12, foram calculados os índices de compressão $\mathrm{C}_{c}$, com valores compreendidos entre 2,5 e 3,7, sendo esses valores maiores que aqueles determinados por Aydilek, Edil e Fox (1999), mas menores que os calculados por Wang et al. (1992).

O’Kelly (2008) realizou ensaios de compressão triaxial em quatro amostras de lodo, visando a determinar os parâmetros de resistência. Cada amostra de lodo foi adensada isotropicamente e foram efetuadas medidas de pressão neutra e deslocamento vertical. Os dados obtidos nos estágios de adensamento de cada amostra de lodo foram empregados para determinar o coeficiente de adensamento $\mathrm{C}_{\mathrm{v}}$. Também foram determinados valores de $\mathrm{C}_{\mathrm{v}}$ a partir dos resultados dos ensaios na célula edométrica e no consolidômetro. Os valores de $\mathrm{C}_{v}$ calculados variaram num intervalo de $3,2 \times 10^{-9}$ a $25,4 \times 10^{-9} \mathrm{~m}^{2} / \mathrm{s}$, e foram menores do que aqueles determinados 
por Aydilek, Edil e Fox (1999). Porém, esses valores de Cv encontram-se entre os valores típicos de argilas moles.

Foram determinados o índice de adensamento secundário $\left(\mathrm{C}_{\alpha \mathrm{e}}\right)$ e o coeficiente de adensamento secundário $\left(\mathrm{C}_{\alpha \varepsilon}\right)$, os quais variaram num intervalo de 0,10 a $0,17 \mathrm{e}$ de 0,008 a 0,017 respectivamente. $A$ razão $C_{\alpha e} / C_{c}$ das amostras de lodo variou entre 0,03 e 0,06 .

\subsubsection{Permeabilidade}

Dado que não existem normas técnicas específicas para realização de ensaios geotécnicos com lodo de ETA, os pesquisadores têm utilizado aquelas destinadas aos solos, as quais devem, porém, sofrer algumas modificações para atender ao novo material. Para determinar o coeficiente de condutividade hidráulica $(k)$ dos lodos de ETA, utiliza-se geralmente o ensaio de adensamento edométrico, calculando-se $k$ a partir do coeficiente de adensamento $\left(\mathrm{C}_{\mathrm{v}}\right)$.

Raghu et al. (1987) determinaram o coeficiente de condutividade hidráulica (k) de um lodo de uma ETA que utiliza cal e sulfato de alumínio como coagulantes por meio de ensaios de adensamento, visando à utilização do lodo como material de revestimento de fundo de aterros sanitários. Os ensaios foram realizados em amostra de lodo compactada com energia Proctor modificado, na umidade ótima e via úmida, num grau de compactação de $90 \%$. Os valores de $k$ obtidos encontraram-se na ordem de $10^{-9} \mathrm{~m} / \mathrm{s}$ para índices de vazios entre 1,3 a 1,4 .

Os autores também estudaram a deterioração que poderia causar o lixiviado no lodo, requisito fundamental para um material poder ser utilizado no revestimento de fundo de aterros sanitários. Para tal, foram realizados ensaios de adensamento com amostras de lodo saturadas com chorume durante 7, 14 e 28 dias. Os resultados indicaram que a estrutura do lodo não sofreu deterioração significativa e consequentemente não houve mudanças significativas no coeficiente de condutividade hidráulica, o qual se manteve ao redor de $10^{-9} \mathrm{~m} / \mathrm{s}$.

Ayedilek, Edil e Fox (1999) realizaram ensaios de permeabilidade com um lodo de ETA num consolidômetro, no final do adensamento primário em cada estágio de carregamento durante um ensaio de adensamento. Na Figura 2.13 são apresentados os resultados dos ensaios de permeabilidade, nos quais o valor de $\mathrm{k}$ variou de 
$7,8 \times 10^{-6}$ a $1,2 \times 10^{-9} \mathrm{~m} / \mathrm{s}$ para uma variação correspondente do índice de vazios de 7,20 a 4,14. Além disso, foi estabelecida uma correlação linear entre o logaritmo do coeficiente de condutividade hidráulica e o índice de vazios.

A Figura 2.13 também mostra os resultados obtidos por O'Kelly e Quille (2009), que determinaram os coeficientes de condutividade hidráulica de três diferentes lodos de ETA a partir de resultados de ensaios de adensamento. Também

Figura 2.13 - Coeficientes de condutividade hidráulica de diferentes lodos de ETA.

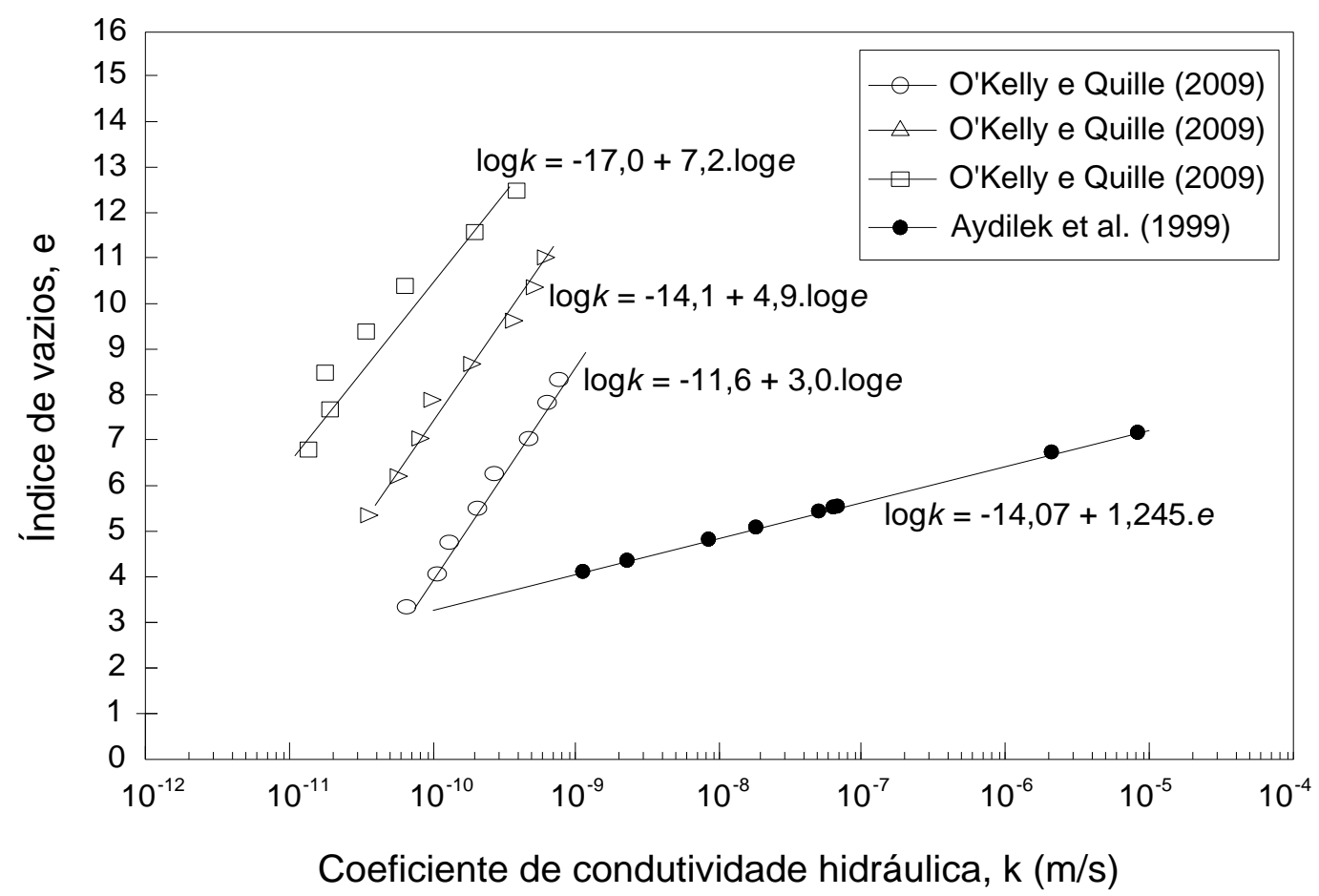

Fonte: adaptado de Aydilek, Edil e Fox (1999) e O'Kelly e Quille (2009) foram estabelecidas correlações de $k$ com o índice de vazios. Os autores obtiveram uma relação linear entre o logaritmo de $k$ e o logaritmo do índice de vazios, com uma tendência de aumento do logk com o aumento de loge. Pode-se observar que o lodo estudado por Ayedilek, Edil e Fox (1999) é muito mais permeável do que os lodos estudados por O'Kelly e Quille (2009).

Assim como O'Kelly e Quille (2009), Wang e Tseng (1993) também encontraram uma relação linear entre o loge e o logk. Esses autores realizaram ensaios de adensamento com amostras de lodo de alumínio visando estudar a 
permeabilidade do lodo. Os ensaios foram efetuados com amostras in natura e curadas durante um e dois meses. Apresentou-se pouca ou nenhuma variação do coeficiente de condutividade hidráulica $(\mathrm{k})$ das amostras curadas e não curadas. $\mathrm{O}$ valor de $\mathrm{k}$ variou de $3 \times 10^{-10}$ a $8 \times 10^{-8} \mathrm{~m} / \mathrm{s}$ correspondendo a um intervalo do índice de vazios de 7 a 17. Para esse intervalo do índice de vazios, os autores estabeleceram a função potência que correlaciona o valor de k e o índice de vazios:

$$
k=\left(2,13 * 10^{-15}\right) * e^{6,15}
$$

Essas pesquisas utilizaram lodo in natura, ou seja, com elevado teor de umidade. No entanto, Rodriguez et al. (2011) realizaram ensaio de permeabilidade em permeâmetro de carga variável com um lodo de ETA desidratado em leito de secagem até uma umidade abaixo de 15\%, umidade na qual as partículas de lodo se aglomeraram formando partículas de maior tamanho, apresentando-se o lodo como não plástico e de comportamento granular. $O$ ensaio foi realizado com amostra de lodo compactada com energia Proctor normal, obtendo-se um valor do coeficiente de condutividade hidráulica de $9,4 \times 10^{-9} \mathrm{~m} / \mathrm{s}$, valor consideravelmente baixo, mas coerente com uma amostra compactada, além de ser muito próximo aos valores obtidos por Raghu et al. (1987), que também utilizaram lodo compactado, porém na energia Proctor modificada.

\subsubsection{Resistência ao cisalhamento}

A resistência ao cisalhamento é uma das propriedades mais importantes dos solos, pois os parâmetros de resistência influenciam a estabilidade de taludes (naturais, de aterros e de cortes) e a capacidade de suporte. Essas propriedades de resistência também são aplicáveis aos lodos de ETA empregados em obras geotécnicas.

Os parâmetros de resistência podem ser determinados por meio de ensaios de cisalhamento direto e de ensaios triaxiais, sendo esse último tipo de ensaio o empregado pela maioria dos autores que determinaram parâmetros de resistência de lodos de ETA (HSIEH; RAGHU, 1997; O’KELLY, 2008; O’KELLY; QUILLE, 2010; ROQUE; CARVALHO, 2006). Os ensaios triaxiais realizados são do tipo adensado não drenado (consolidated undrained, CU) e não adensado não drenado 
(unconsolidated undrained, UU) para determinar os parâmetros de resistência efetivos e a resistência não drenada, respectivamente.

Hsieh e Raghu (1997) determinaram os parâmetros de resistência, coesão e ângulo de atrito, de onze diferentes lodos de ETA por ensaios de cisalhamento direto na condição não drenada, apresentados na Tabela 2.13. Pode ser observado que para alguns lodos com teor de umidade entre 34 e $89 \%$ foram obtidos valores de coesão variando entre 15 e $45 \mathrm{kPa}$; no caso de teores de umidade de $100 \%$ até $549 \%$, os valores de coesão em geral foram baixos, na ordem de 2 a $11 \mathrm{kPa}$. O ângulo de atrito das amostras variou de 3 a 26을 estando os maiores valores relacionados aos menores teores de umidade, e lembrando-se que esses valores são dados em termos de tensões totais. É importante também apontar para o fato de que esses valores de ângulo de atrito não refletem o atrito entre as partículas, pois no ensaio são cisalhados os flocos e não as partículas de lodo. Segundo os autores, a matéria orgânica também joga um papel importante na determinação do ângulo de atrito, lubrificando a superfície dos flocos e reduzindo o atrito entre elas.

Tabela 2.13 - Parâmetros de resistência de lodos de ETA, obtidos mediante ensaios de cisalhamento direto.

\begin{tabular}{cccc}
\hline Teor de sólidos (\%) & Teor de umidade w (\%) & Coesão c (kPa) & Ângulo de atrito $\phi\left(\mathbf{o}^{\mathbf{9}}\right)$ \\
\hline 15,4 & 549,4 & 4,2 & 3 \\
19,8 & 405,1 & 2,4 & 7 \\
24,6 & 306,5 & 10,6 & 6 \\
34,6 & 189,0 & 11,4 & 9 \\
38,9 & 157,1 & 3,4 & 20 \\
39,9 & 150,6 & 3,0 & 9 \\
52,9 & 89,0 & 20,7 & 19 \\
59,7 & 67,5 & 15,5 & 26 \\
64,1 & 56,0 & 3,1 & 20 \\
72,6 & 37,7 & 17,7 & 16 \\
74,7 & 33,9 & 45,1 & 24 \\
\hline
\end{tabular}

Fonte: Hsieh e Raghu (1997)

A Tabela 2.14 apresenta os parâmetros de resistência de diferentes lodos de ETA, obtidos por diversos autores a partir de ensaios triaxiais tipo CU. Em dois trabalhos os ensaios foram realizados em amostras com teor de umidade próximo à 
umidade do lodo in natura, apresentando resultado de material não coesivo, enquanto Roque e Carvalho (2006) empregaram amostras previamente secas em estufa (50 a $60{ }^{\circ} \mathrm{C}$ ) e compactadas na umidade ótima com energia Proctor normal, o que poderia explicar o valor da coesão efetiva relativamente alto obtido por esses autores.

O comportamento não coesivo pode também ser constatado pelos valores do ângulo de atrito, os quais variaram num intervalo de 39 a $44^{\circ}$ com um valor médio de $42^{\circ}$. Esses valores de ângulo de atrito são consideravelmente altos, pois apresentamse normalmente em solo granulares e não em solos plásticos; argilas com índices de plasticidade de acima de 50 apresentam valores de ângulo de atrito menores que 25은 (HOLTZ; KOVACS, 1981). Segundo O’Kelly (2008), não é incomum que alguns resíduos sólidos muito plásticos tenham elevados valores de ângulo de atrito efetivo.

Tabela 2.14 - Parâmetros de resistência obtidos mediante ensaios triaxiais.

\begin{tabular}{lcc}
\hline \multicolumn{1}{c}{ Autor } & $\begin{array}{c}\text { Coesão efetiva } \\
\mathbf{c}^{\prime}(\mathbf{k P a})\end{array}$ & $\begin{array}{c}\text { Ângulo de atrito } \\
\left.\text { efetivo } \phi^{\prime} \mathbf{(}^{\circ}\right)\end{array}$ \\
\hline Wang et al. (1992) & 8,3 & 43 \\
Wang et al. (1992) & 6,9 & 42 \\
Wang et al. (1992) & 8,3 & 44 \\
Roque e Carvalho (2006) & 77,0 & 44 \\
O'Kelly e Quille (2008) & 0,0 & 39 \\
O'Kelly e Quille (2010) & 0,0 & 42 \\
O'Kelly e Quille (2010) & 0,0 & 42 \\
O'Kelly e Quille (2010) & 0,0 & 40 \\
O'Kelly e Quille (2010) & 0,0 & 44 \\
\hline
\end{tabular}

Fonte: adaptado de vários autores

A resistência não drenada pode ser determinada por meio de ensaios de compressão triaxial tipo UU, de cone, de palheta e de compressão simples, entre outros. Raghu et al. (1987) realizaram ensaios de compressão simples em onze lodos de diferentes ETAs, Wang et al. (1992) utilizaram o ensaio de cone em três lodos, Cornwell et al. (1992) realizaram ensaios de cone e triaxiais em três diferentes lodos, e O'Kelly (2008) realizou ensaios triaxiais do tipo UU em um lodo. 
Todos esses autores determinaram a resistência não drenada correspondente a distintos teores de sólidos das amostras de lodo, obtendo assim uma ampla variedade de resultados. Foram determinados dois tipos de comportamento da resistência não drenada em função do aumento do teor de sólidos: curva crescente e curva de formato parabólico, como a curva de compactação típica.

Os resultados obtidos por Wang et al. (1992) são apresentados na Figura 2.14. As curvas são crescentes, como reportado nos resultados dos ensaios de Cornwell et al. (1992) e em alguns dos resultados de Raghu et al. (1987). Segundo Raghu et al. (1987), esse comportamento pode ser devido à ocorrência de cimentação das partículas com a secagem e consequente ganho de resistência. A maioria das curvas de resistência não drenada em função do teor de sólidos obtidas por esses autores, contudo, apresentaram um formato parabólico, permitindo determinar assim um valor do teor de sólidos ótimo para cada lodo (Figura 2.15).

Figura 2.14 - Resistência não drenada de lodos de ETA obtida a partir de ensaio do cone.

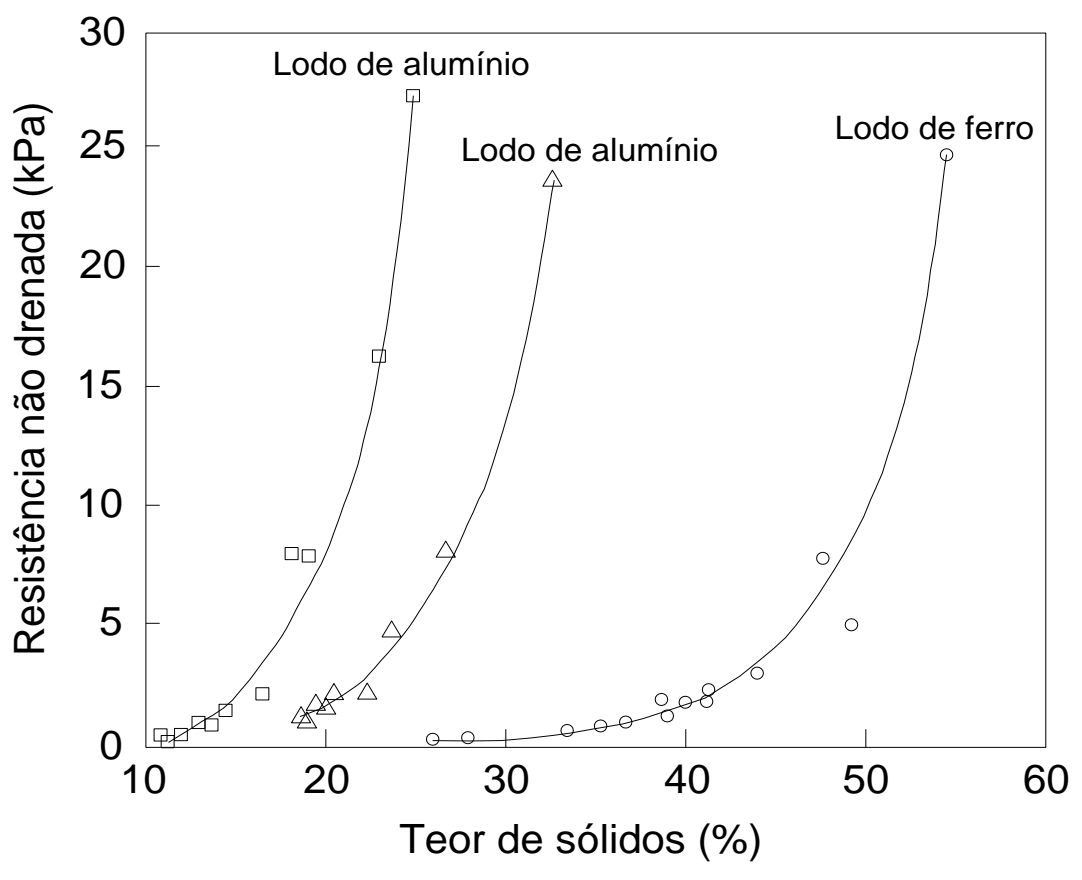

Fonte: Wang et al. (1992) 
Os valores de resistência não drenada obtidos por Raghu et al. (1987) foram muito maiores do que os reportados por Wang et al. (1992) para um mesmo teor de sólidos. Essa diferença de valores pode ser devida à utilização de ensaios diferentes pelos autores ou às propriedades de resistência próprias dos lodos estudados. Solos com baixa plasticidade em geral apresentam uma resistência maior do que aqueles com alta plasticidade exceto para baixas tensões confinantes. Os lodos estudados por Wang et al. (1992) apresentaram índices de plasticidade elevados (61, 311, 286), enquanto os estudados por Raghu et al. (1987) tinham baixa ou nenhuma plasticidade, o que poderia explicar as diferenças entre os resultados obtidos.

Figura 2.15 - Resistência não drenada de lodos de ETA obtida a partir de ensaio de compressão simples.

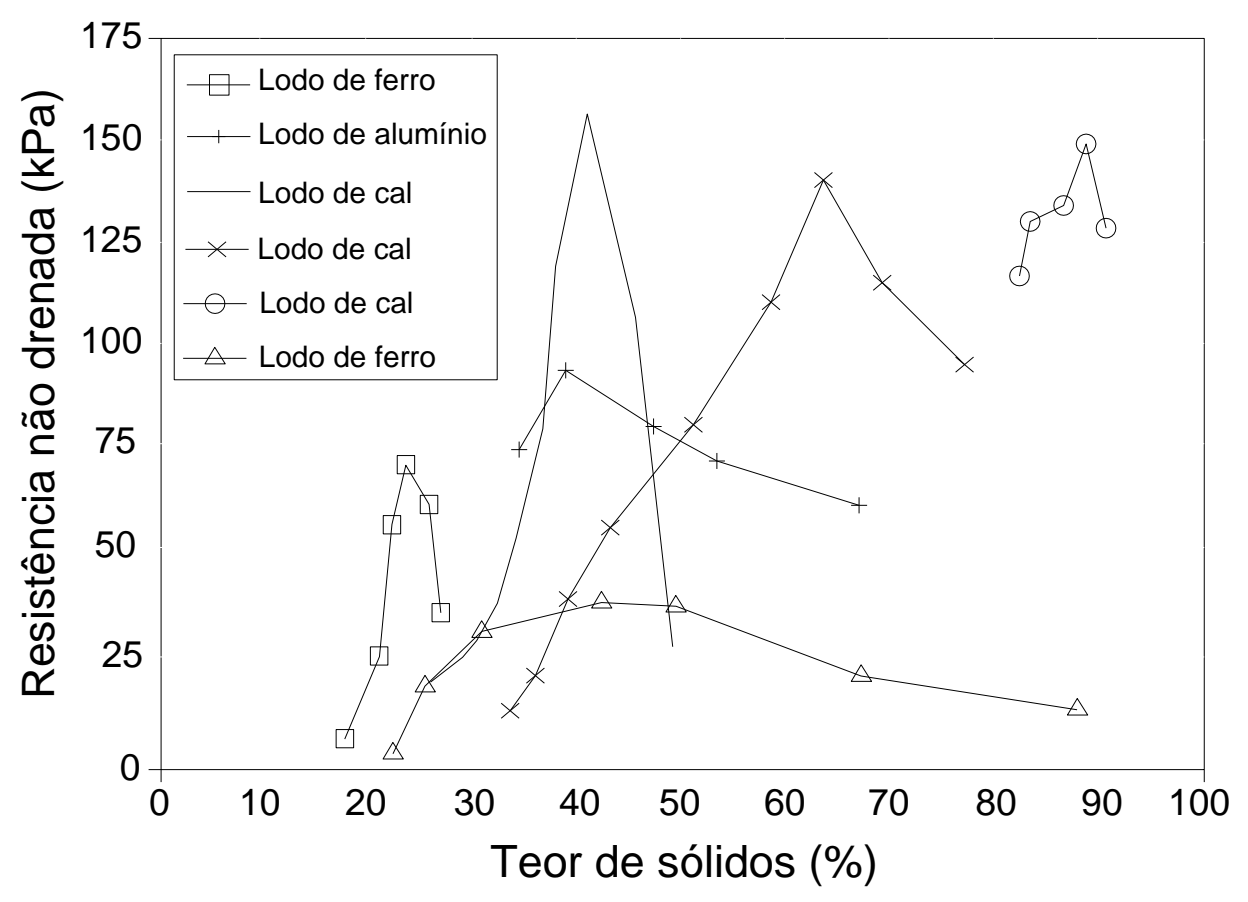

Fonte: Raghu et al. (1987)

\subsection{PARÂMETROS GEOTÉCNICOS DESEJÁVEIS EM SOLOS PARA CONSTRUCÇÃO DE ATERROS}

\subsubsection{Aterros sanitários}

As normas brasileiras relativas ao projeto, implantação e operação de aterros sanitários não apresentam nenhuma especificação técnica a respeito das propriedades geotécnicas das camadas de cobertura diária e final em aterros 
sanitários. A norma ABNT-NBR 13896/1997 indica apenas que a cobertura final deve "minimizar a infiltração de água na célula, exigir pouca manutenção, não estar sujeita a erosão, acomodar assentamento sem fratura, e possuir um coeficiente de permeabilidade inferior ao do solo natural da área do aterro". Esta norma não menciona nenhuma recomendação com relação a coberturas diárias, possivelmente porque a exigência de baixa permeabilidade não é de grande importância como no caso da cobertura final, pois o propósito da cobertura diária, que é colocada no final de cada dia de trabalho, é o de controlar vetores (mosquitos, moscas etc.), incêndios por explosão de biogás, emanação de odores, espalhamento do lixo para fora da célula e animais carniceiros (CALRECYCLE, 2016).

O principal parâmetro considerado nas coberturas finais e nos revestimentos de fundo de aterros sanitários é a condutividade hidráulica, pois baixa permeabilidade reduz, respectivamente, a infiltração de água no maciço sanitário e a contaminação do aquífero. A USEPA (1993) recomenda que a cobertura final em aterros sanitários deve ser projetada e construída de maneira que a condutividade hidráulica seja igual ou inferior àquela da camada de impermeabilização de fundo, inferior à do solo da

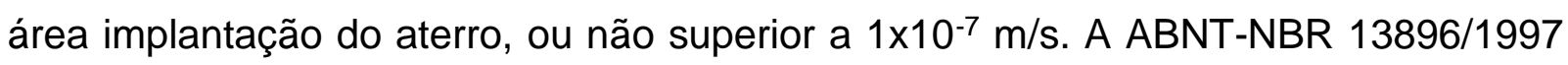
também estabelece um valor de $1 \times 10^{-7} \mathrm{~m} / \mathrm{s}$ como limite máximo para a condutividade hidráulica das camadas de impermeabilização e cobertura. Por outro lado, autores como Daniel (1993); Rocca, lacovone e Barrotti (1993); e Qasim e Chiang (1994) estabelecem que a condutividade hidráulica da camada de impermeabilização deve ser inferior a $1 \times 10^{-9} \mathrm{~m} / \mathrm{s}$.

Segundo Rocca, lacovone e Barrotti (1993), para um solo argiloso ser considerado adequado para impermeabilização de aterros sanitários, tanto em camada de fundo quanto em cobertura final, deve atender às seguintes características: ser classificado como $\mathrm{CL}, \mathrm{CH}, \mathrm{SC}$ ou $\mathrm{OH}$ (segundo o SUCS); porcentagem maior do que $30 \%$ de partículas passando pela peneira 200; LL maior ou igual a $30 \%$; IP maior ou igual a 15; $\mathrm{pH}$ maior ou igual a 7 ; e coeficiente de condutividade hidráulica inferior a $10^{-9} \mathrm{~m} / \mathrm{s}$ quando compactado. Segundo Boscov (2010), essas recomendações são muito discutíveis. Por exemplo, os solos tropicais são geralmente ácidos (FADIGAS et al., 2002) e mesmo solos argilosos podem ser classificados como MH e ML (NOGAMI; VILLIBOR, 1995); não obstante, apresentam bom desempenho como camadas impermeabilizantes de aterros sanitários. 
Diversos autores têm sugerido critérios para garantir uma condutividade hidráulica máxima de $1 \times 10^{-9} \mathrm{~m} / \mathrm{s}$, uma adequada trabalhabilidade e adequada compactação do solo em campo visando seu uso em camadas de impermeabilização. Na Tabela 2.15 são apresentados os critérios estabelecidos por distintos autores, principalmente relacionados aos limites de Atterberg e às porcentagens das frações argila e silte.

Tabela 2.15 - Requerimentos para camada de impermeabilização de fundo.

\begin{tabular}{ccc}
\hline Parâmetro & Referência & Critério \\
\hline & DOE (1995) & $10 \%<\mathrm{IP}<30 \%$ \\
& Daniel (1993) & $7 \%<\mathrm{IP}<10 \%$ \\
Plasticidade & NRA (1992) & $\mathrm{LL}<90 \% ; \mathrm{IP}<65 \%$ \\
& Murray et al. (1992) & $\mathrm{IP}>12 \%$ \\
& Gordon (1987) & $\mathrm{IP}>15 \%$ \\
& Williams (1987) & $\mathrm{IP}>15 \%$ \\
\hline \multirow{2}{*}{ Porcentagem de finos } & Daniel (1993) & Argila e silte $>20-30 \%$ \\
& NRA (1992) & Argila $>10 \%$ \\
\hline Atividade (IP/\%argila) & Gordon (1987) & Argila e silte $>50 \%$ \\
\hline
\end{tabular}

Fonte: adaptado de Murray, Dixon e Jones (1998).

\subsubsection{Barragens}

Em barragens, diferentemente de aterros sanitários, não existe normativa de requerimentos mínimos ou máximos dos parâmetros geotécnicos dos solos a serem empregados. Para a construção de barragens, os solos são selecionados considerando seu desempenho geotécnico relacionado às diferentes condições da obra (solo de fundação, tipo de barragem, estabilidade, erosão etc.).

As barragens de terra podem ser construídas com um único solo (barragem homogênea) ou podem ser zoneadas. Por um lado, argilas são os materiais indicados para construção do núcleo da barragem, dada sua baixa permeabilidade. Por outro lado, areias argilosas ou siltosas também pode ter um bom desempenho nos espaldares de barragens zoneadas, pois areias geralmente apresentam maior resistência a cisalhamento do que argilas, o que garante maior estabilidade dos taludes. 
Na Tabela 2.16 são apresentados alguns parâmetros geotécnicos (LL, IP, Wót, yd máx, c', $\varphi$ ) de vários solos lateríticos, obtidos por Cruz (1967). Os parâmetros de resistência em termos de tensões efetivas (c', $\varphi$ ) foram determinados em amostras compactadas na energia Proctor normal. Esses solos foram amplamente utilizados na construção de diversas barragens, as quais apresentaram ótimo desempenho na maioria dos casos.

Tabela 2.16 - Parâmetros geotécnicos de solos residuais lateríticos utilizados na construção de barragens.

\begin{tabular}{|c|c|c|c|c|c|c|c|}
\hline \multirow[t]{2}{*}{ Amostra / Procedência } & \multicolumn{2}{|c|}{$\begin{array}{l}\text { Limites de } \\
\text { Atterberg }\end{array}$} & \multirow{2}{*}{$\begin{array}{c}\text { Classificação } \\
\text { SUCS }\end{array}$} & \multicolumn{2}{|c|}{$\begin{array}{l}\text { Parâmetros de } \\
\text { Compactação } \\
\text { Proctor Normal }\end{array}$} & \multicolumn{2}{|c|}{$\begin{array}{c}\text { Parâmetros de } \\
\text { resistência ao } \\
\text { cisalhamento }\end{array}$} \\
\hline & $\begin{array}{l}\mathrm{LL} \\
(\%)\end{array}$ & $\begin{array}{l}\text { IP } \\
(\%)\end{array}$ & & $\begin{array}{l}\text { Wót } \\
(\%)\end{array}$ & $\begin{array}{c}\gamma_{d \text { máx }} \\
\left(\mathrm{g} / \mathrm{cm}^{3}\right)\end{array}$ & $\begin{array}{c}\mathrm{c}^{\prime} \\
\left(\mathrm{kg} / \mathrm{cm}^{2}\right)\end{array}$ & $\begin{array}{l}\varphi^{\prime} \\
\left({ }^{\circ}\right)\end{array}$ \\
\hline Promissão S-6 (SP) & 23 & 13 & $\mathrm{SP}$ & 9,5 & 2,036 & 0,08 & 34,0 \\
\hline Prom. Macuco C (SP) & 17 & 7 & SP & 9,7 & 2,050 & 0,10 & 35,0 \\
\hline Prom. P.Queixada (SP) & 18 & 6 & SP & 9,7 & 1,984 & 0,08 & 33,5 \\
\hline 3 Irmãos F.G. (SPO & 24 & 12 & SP & 10,0 & 2,020 & 0,10 & 34,0 \\
\hline Prom. Macuco A (SP) & 20 & 7 & SP & 10,2 & 2,037 & 0,05 & 35,0 \\
\hline Xavantes C (SP) & 20 & 3 & SC & 10,7 & 1,980 & 0,00 & 33,0 \\
\hline Jupiá (SP-MT) & 25 & 11 & $C L$ & 10,9 & 1,995 & 0,05 & 33,0 \\
\hline Taquaruçu (SP-PR) & 29 & 16 & $\mathrm{CL}$ & 11,2 & 1,980 & 0,05 & 33,0 \\
\hline Guaíra M.D. (SP) & 25 & 8 & SP & 11,5 & 1,960 & 0,05 & 31,0 \\
\hline Ibitinga (SP) & 24 & 7 & SP & 12,0 & 1,950 & 0,20 & 32,0 \\
\hline Ilha Solteira I (SP-MT) & 24 & 8 & $\mathrm{CL}$ & 12,2 & 1,925 & 0,05 & 33,5 \\
\hline Xavantes C' (SP) & 25 & 9 & SP & 12,7 & 1,884 & 0,15 & 33,0 \\
\hline Anhembi (SP) & 35 & 16 & $\mathrm{CL}$ & 13,5 & 1,860 & 0,07 & 34,0 \\
\hline Xavantes $\mathrm{H}_{1}(\mathrm{SP})$ & 31 & 14 & $\mathrm{CL}$ & 14,0 & 1,812 & 0,10 & 33,5 \\
\hline Guaíra eixo 2-3 (SP) & 33 & 14 & $\mathrm{CL}$ & 15,3 & 1,820 & 0,00 & 28,5 \\
\hline Promissão S-3 (SP) & 37 & 22 & $\mathrm{CL}$ & 17,6 & 1,774 & 0,30 & 26,5 \\
\hline Ilha Solteira II (SP-MT) & 36 & 12 & $\mathrm{CL}$ & 17,1 & 1,737 & 0,10 & 33,0 \\
\hline Dona Francisca B6 (RS) & 40 & 21 & $C L$ & 17,2 & 1,770 & 0,10 & 28,5 \\
\hline Dona Francisca B8 (RS) & 40 & 18 & $C L$ & 19,3 & 1,668 & 0,10 & 30,5 \\
\hline Dona Francisca B9 (RS) & 52 & 27 & $\mathrm{CL}$ & 22,0 & 1,620 & 0,10 & 26,5 \\
\hline Ilha Solteira III (SP-MT) & 46 & 15 & $C L$ & 22,1 & 1,632 & 0,15 & 30,0 \\
\hline
\end{tabular}




\section{MATERIAIS E MÉTODOS}

\subsection{INTRODUÇÃO}

Nesta pesquisa foram determinadas e estudadas as características e parâmetros geotécnicos de um solo arenoso de grande ocorrência no estado de São Paulo, de um lodo de ETA e de misturas desses materiais em distintas proporções. As proporções das misturas foram definidas com predominância de solo (quantidade maior de solo do que de lodo), objetivando estudar o teor de lodo que pode ser acrescentado ao solo sem perda da "qualidade geotécnica", ou seja, sem haver mudança significativa no comportamento do solo no sentido de torná-lo menos adequado para aplicações geotécnicas.

O solo e o lodo foram caracterizados química e mineralogicamente. Além disso, foi realizada a caracterização geotécnica do solo, do lodo e das misturas sololodo, assim como a determinação dos parâmetros de deformabilidade, permeabilidade e resistência ao cisalhamento.

Os ensaios geotécnicos foram realizados segundo as normas da Associação Brasileira de Normas Técnicas (ABNT), no entanto, foram feitas algumas adaptações devido ao fato de o lodo apresentar um comportamento diferente da maioria dos solos naturais, para os quais as normas têm sido desenvolvidas.

\subsection{DESCRIÇÃO DOS MATERIAIS}

\subsubsection{Lodo de ETA}

O lodo utilizado nesta pesquisa é proveniente da ETA Cubatão, localizada no Município de Cubatão nas coordenadas 352903E e 7358129S (Figura 3.1), a qual é uma das ETAs administradas pela SABESP.

A ETA Cubatão tem uma capacidade de tratamento de $4,5 \mathrm{~m}^{3} / \mathrm{s}$ de água bruta, captada no rio Cubatão. No processo de tratamento da água bruta é utilizado o cloreto férrico como agente coagulante, além de outros produtos químicos, como cal virgem, ácido fluorsilícico e cloro líquido. Atualmente, a produção de lodo na ETA é de aproximadamente 60 a 70 t/dia em peso úmido, e todo esse resíduo está sendo transportado para um aterro industrial local. 
Os pontos de geração de lodo localizam-se nos decantadores e nos filtros. Nos decantadores, o lodo formado no fundo é lavado periodicamente. Nos filtros, a água de lavagem é bombeada para um tanque de sedimentação, onde também se sedimenta lodo no fundo. Os lodos sedimentados dos filtros e os provenientes dos decantadores, ainda com muita água, são encaminhados para um tanque de estocagem.

Figura 3.1 - Localização da ETA Cubatão.
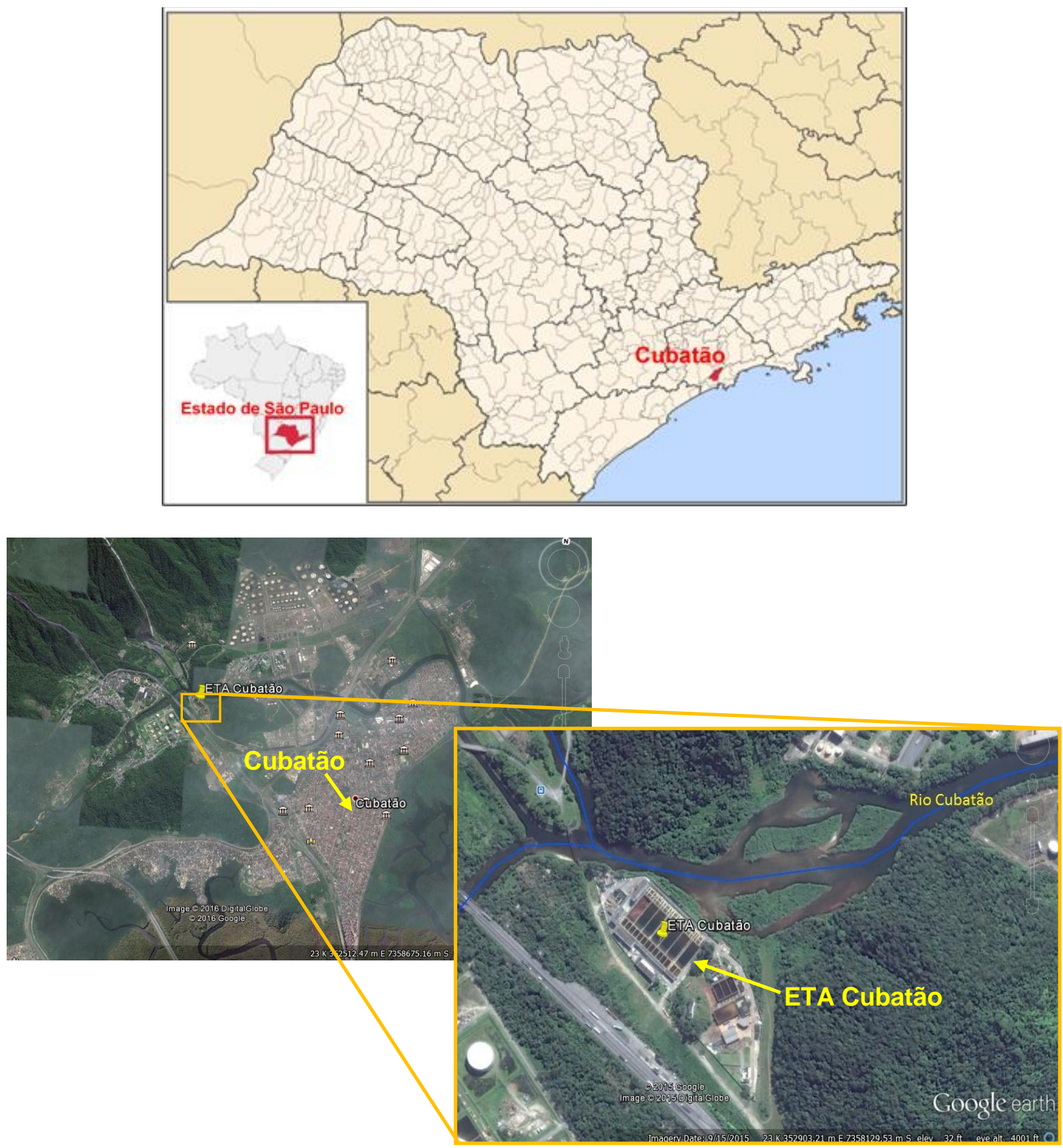

Fonte: adaptado de Wikipédia e Google Earth em 20/10/2015. 
Após sedimentação no tanque de estocagem, ao serem retirados encontramse com um baixo teor de sólidos ( 1 a $4 \%$ ), fato pelo qual é necessária a remoção de água para facilitar o transporte e disposição final. Para tal fim, os lodos acumulados no tanque de estocagem são removidos pelo fundo e bombeados para centrífugas de desaguamento, obtendo-se assim lodo com teor de sólidos entre 20 e $25 \%$. A Figura 3.3 mostra uma das quatro centrífugas empregadas no processo de desidratação do lodo.

Figura 3.3 - Centrífuga utilizada na desidratação do lodo.

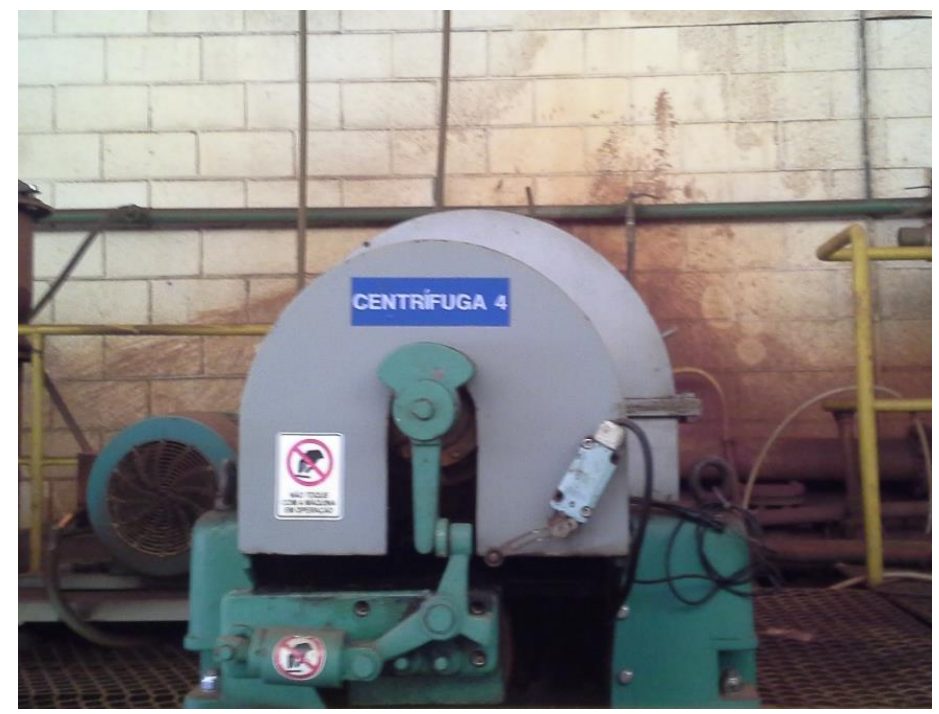

Fonte: Autor

Figura 3.2 - Amostras de lodo da ETA armazenadas em sacos plásticos.

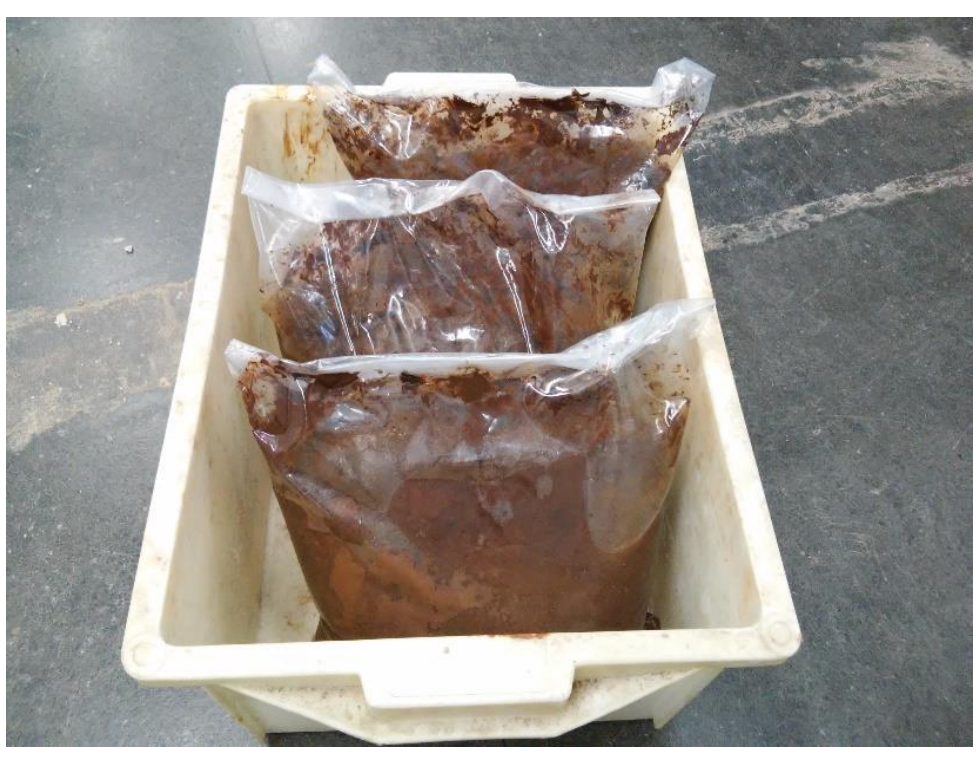

Fonte: Autor 
O lodo utilizado na pesquisa foi coletado diretamente nas centrífugas da ETA Cubatão, em maio de 2015 e fevereiro de 2016, colocado em sacos plásticos (Figura 3.2), transportado para o Laboratório de Mecânica dos Solos da Escola Politécnica da Universidade de São Paulo (LMS-EPUSP) e armazenado na câmera úmida.

\subsubsection{Solo}

O solo empregado na pesquisa é uma areia argilosa laterítica, proveniente da região do aterro sanitário do município de Botucatu, SP (Figura 3.4).

Essa região apresenta uma estratigrafia associada aos arenitos das formações Botucatu e Piramboia. A formação Botucatu é constituída por arenitos de granulação média a fina com coloração vermelha, rósea ou amarelo-clara. Os solos laterizados nessas regiões são em geral arenosos e a contribuição de material fino na granulometria é menor que 20\% (ZANON, 2014). De acordo com o IBGE (2001), a classificação pedológica do subsolo da região do município de Botucatu é a de latossolo vermelho. A classe latossolo é a de maior ocorrência no estado de São Paulo, correspondendo a cerca de $52 \%$ da sua área.

O solo laterítico da região de Botucatu foi utilizado na pesquisa sobre avaliação da contaminação por lixiviado de aterro sanitário de Zanon (2014), que coletou amostras deformadas e indeformadas do solo local e realizou a caracterização química, mineralógica e geotécnica do material. Durante esta pesquisa, efetuou-se mais uma coleta de solo no mesmo local, em fevereiro de 2016. A amostra coletada foi deformada, retirada de uma vala escavada por retroescavadeira no mesmo ponto de coleta de Zanon (2014). 
Figura 3.4 - Vista regional do sitio de amostragem do solo.
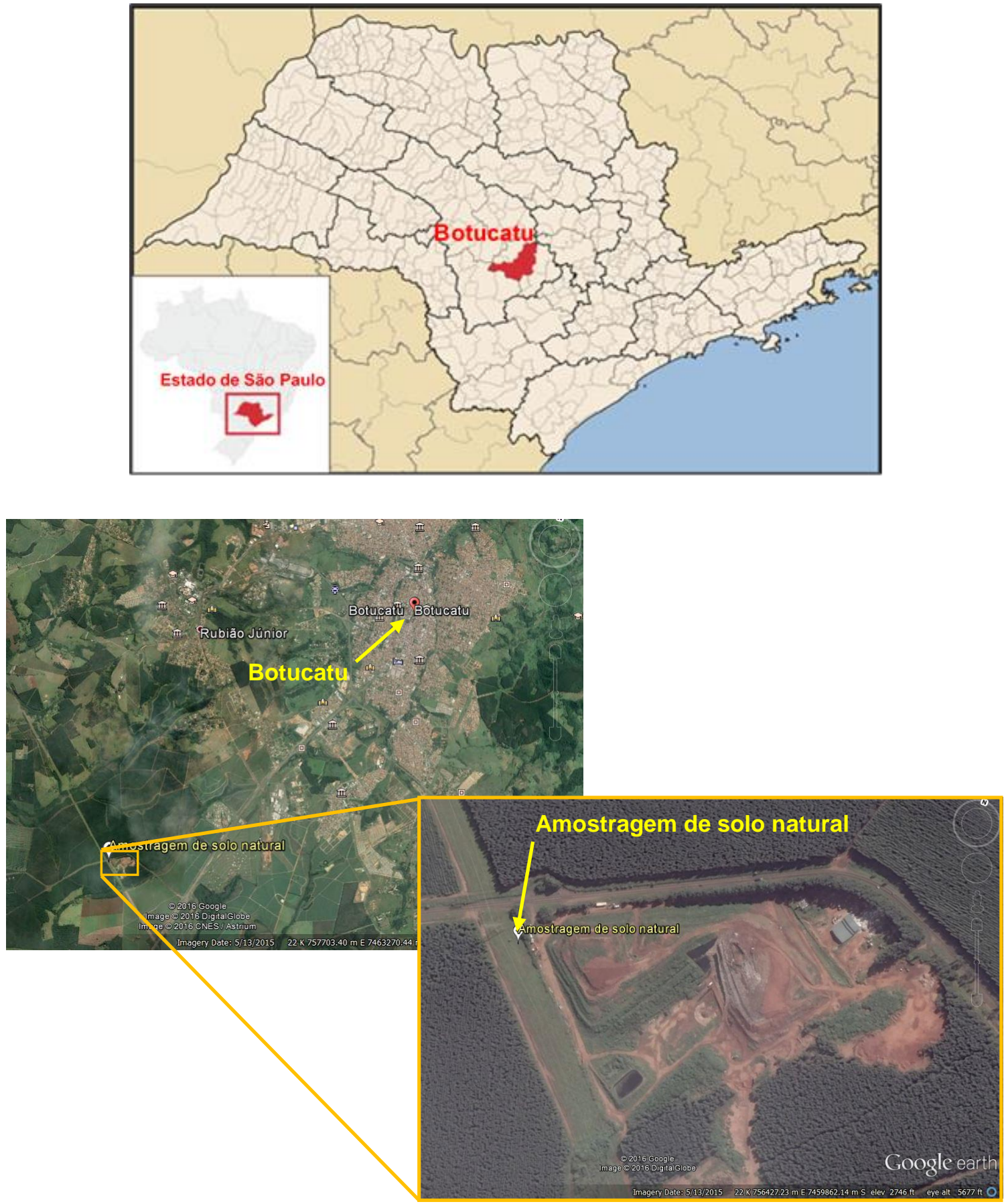

Fonte: adaptado de Wikipédia e Google Earth em 22/02/2016. 


\subsection{CARACTERIZAÇÃO QUÍMICA E MINERALÓGICA}

A caracterização química e mineralógica do solo apresentada neste item foi reproduzida de Zanon (2014). Enquanto a caracterização química e mineralógica do lodo foi realizada no âmbito desta pesquisa.

\subsubsection{Caracterização química do solo}

Os resultados da caracterização química do solo, realizadas no Laboratório de Análise de Solos do Departamento de Ciência do Solo da Escola Superior de Agricultura Luiz de Queiroz da USP (LSO-ESALQ) segundo os métodos da EMBRAPA (1997), são apresentados na Tabela 3.1.

Tabela 3.1 - Resultados das análises químicas do solo.

\begin{tabular}{|c|c|}
\hline Parâmetro & Valor \\
\hline $\mathrm{pH}\left(\mathrm{em} \mathrm{H} \mathrm{H}_{2} \mathrm{O}\right)$ & 5,7 \\
\hline $\mathrm{pH}$ (em solução de $\mathrm{KCl} 1$ mol.L-1) & 4,4 \\
\hline $\mathrm{P}\left(\mathrm{mg} \cdot \mathrm{kg}^{-1}\right)$ & $<1$ \\
\hline $\mathrm{K}\left(\mathrm{mmolc} . \mathrm{kg}^{-1}\right)$ & $<0,3$ \\
\hline $\mathrm{Ca}\left(\mathrm{mmolc} . \mathrm{kg}^{-1}\right)$ & $<2$ \\
\hline $\mathrm{Mg}\left(\mathrm{mmolc} . \mathrm{kg}^{-1}\right)$ & 1 \\
\hline $\mathrm{Al}\left(\mathrm{mmolc} . \mathrm{kg}^{-1}\right)$ & 3 \\
\hline $\mathrm{H}^{+}+\mathrm{Al}^{3+}\left(\right.$ mmolc. $\left.\mathrm{kg}^{-1}\right)$ & 22 \\
\hline Soma de bases trocáveis (mmolc. $\mathrm{kg}^{-1}$ ) & 1,8 \\
\hline Capacidade de troca catiônica - CTC (mmolc.kg-1) & 23,4 \\
\hline Saturação da CTC por bases (\%) & 8 \\
\hline Saturação por alumínio (\%) & 65 \\
\hline Matéria orgânica (g/kg) & 7 \\
\hline Carbono orgânico (g/kg) & 4 \\
\hline
\end{tabular}

Fonte: Zanon (2014)

\subsubsection{Caracterização mineralógica do solo}

A caracterização mineralógica compreendeu ensaios de difração de raios $X$, fluorescência de raios $X$ e microscopia eletrônica de varredura, realizados no Laboratório de Caracterização Tecnológica da Escola Politécnica da USP (LCTEPUSP). Os resultados da caracterização mineralógica são apresentados nas Tabela 3.2 e Tabela 3.3. 
Tabela 3.2 - Composição mineralógica do solo.

\begin{tabular}{cc}
\hline Mineral & Formula \\
\hline Quartzo & $\mathrm{SiO}_{2}$ \\
Caulinita & $\mathrm{Al}_{2} \mathrm{Si}_{2} \mathrm{O}_{5}(\mathrm{OH})_{4}$ \\
Gibbsita & $\mathrm{Al}(\mathrm{OH})_{3}$ \\
Hematita & $\mathrm{Fe}_{2} \mathrm{O}_{3}$ \\
Anatásio & $\mathrm{TiO}_{2}$ \\
\hline
\end{tabular}

Fonte: Zanon (2014)

Tabela 3.3 - Resultados do ensaio de fluorescência de raios $\mathrm{X}$.

\begin{tabular}{cccc}
\hline $\begin{array}{c}\text { Composto } \\
\text { químico }\end{array}$ & $\begin{array}{c}\text { Teor normalizado do } \\
\text { composto químico (\%) }\end{array}$ & $\begin{array}{c}\text { Composto } \\
\text { químico }\end{array}$ & $\begin{array}{c}\text { Teor normalizado do } \\
\text { composto químico (\%) }\end{array}$ \\
\hline $\mathrm{MgO}$ & 0,04 & $\mathrm{MnO}$ & 0,03 \\
$\mathrm{Al}_{2} \mathrm{O}_{3}$ & 16,5 & $\mathrm{Fe}_{2} \mathrm{O}_{3}$ & 7,17 \\
$\mathrm{SiO}_{2}$ & 68,1 & $\mathrm{NiO}$ & 0,01 \\
$\mathrm{P}_{2} \mathrm{O}_{5}$ & 0,05 & $\mathrm{CuO}$ & 0,04 \\
$\mathrm{SO}_{3}$ & 0,02 & $\mathrm{ZnO}$ & 0,01 \\
$\mathrm{Cl}$ & 0,01 & $\mathrm{Y}_{2} \mathrm{O}_{3}$ & $<0,01$ \\
$\mathrm{~K} 2 \mathrm{O}$ & 0,04 & $\mathrm{ZrO}_{2}$ & 0,07 \\
$\mathrm{CaO}$ & 0,02 & $\mathrm{Nb}_{2} \mathrm{O}_{5}$ & 0,02 \\
$\mathrm{TiO} 2$ & 1,55 & $\mathrm{PbO}^{2}$ & 0,01 \\
$\mathrm{~V}_{2} \mathrm{O}_{5}$ & 0,03 & $\mathrm{TaO}_{2}$ & 0,06 \\
$\mathrm{Cr}_{2} \mathrm{O}_{3}$ & 0,08 & $\mathrm{PF}$ & 6,11 \\
\hline
\end{tabular}

$\mathrm{PF}=$ perda ao fogo

Fonte: Zanon (2014)

\subsubsection{Caracterização química do lodo}

Para a caracterização química do lodo, uma amostra de $300 \mathrm{~g}$ de lodo seco ao ar foi enviada para o LSO-ESALQ, onde foram efetuadas as seguintes análises segundo os métodos da EMBRAPA (1997): $\mathrm{pH}$ em $\mathrm{H}_{2} \mathrm{O}$; $\mathrm{pH}$ em KCl 1 mol L-1; carbono orgânico $(\mathrm{CO})$ e matéria orgânica $(\mathrm{MO})$ por titulometria; cálcio (Ca) e magnésio (Mg) por extração com acetato de amônio e determinação em espectrofotômetro de absorção atômica; potássio (K) por extração com acetato de amônio e determinação em espectrofotômetro de emissão atômica; sódio ( $\mathrm{Na}$ ) por 
extração com acetato de amônio e determinação em fotômetro de chama; acidez potencial $(\mathrm{H}+\mathrm{Al})$ por extração com acetato de cálcio e determinação por titulometria; alumínio (Al) por extração com cloreto de potássio $1 \mathrm{~mol} \mathrm{~L}^{-1}$ e determinação por titulometria; fósforo $(P)$ por extração com Mehlich 1 e determinação por colorimetria.

\subsubsection{Caracterização mineralógica do lodo}

A caracterização mineralógica do lodo foi realizada no LCT-EPUSP, por meio dos ensaios de difração de raios $X$, fluorescência de raios $X$ e microscopia eletrônica de varredura (MEV). Para esses ensaios foi preparada uma amostra de lodo seca em estufa a $35^{\circ} \mathrm{C}$.

As análises de difração de raios $X$ foram realizadas através do método em pó e o emprego de difratômetro de raios X, marca Phillips, modelo MPD 1880.

A identificação das fases cristalinas foi realizada por comparação do difratograma da amostra com os bancos de dados PDF2 do International Centre for Diffraction Data (ICDD, 2003) e PANalitycal Inorganic Cristal Structure Database (PAN-ICSD, 2007).

O ensaio de fluorescência de raios $X$ foi efetuado em espectrômetro AxiosAdvanced PANalytical. Também foi feita análise de perda ao fogo a $1020{ }^{\circ} \mathrm{C}$ durante 2 horas.

A microscopia eletrônica de varredura (MEV) foi realizada em microscópio Quanta 600 FEG, marca FEI, equipado com espectrômetro de raios X por dispersão de energia (EDS) Quantax 400 (tecnologia SDD - Silicon Drift Detector) e software Sprit, marca Bruker. A confecção da lâmina foi normal. A rotina de trabalho estipulada no MEV compreendeu a coleta de imagens de elétrons retroespalhados e análises químicas pontuais (EDS) para caracterizar a composição das partículas. As amostras foram aderidas em fita dupla face de carbono, recobertas com platina e fixadas em suporte próprio para MEV.

\subsection{ENSAIOS GEOTÉCNICOS}

\subsubsection{Preparação das amostras de solo, lodo e misturas}

As amostras de solo para os ensaios de caracterização (análise granulométrica, massa específica dos grãos e limites de consistência) e compactação 
foram preparadas de acordo com método preconizado pela ABNT-NBR 6457/1986 com secagem prévia do material até umidade higroscópica. Foram preparadas duas amostras de solo, uma da primeira coleta e a outra da segunda coleta.

A preparação das amostras de lodo para os ensaios de caracterização não foi realizada como preconizado pela norma da ABNT. Para a análise granulométrica e determinação da massa específica dos grãos as amostras foram utilizadas na umidade in natura (350\%), pois tem sido demonstrado por alguns autores que a secagem prévia do lodo de ETA afeta os valores determinados da massa específica dos grãos, a distribuição granulométrica e os limites de consistência (XIA, 1994; BASIM, 1999a; WATANABE et al., 2011). Para os limites de consistência foram utilizadas amostras com secagem prévia até a umidade inicial de cada ensaio (LL e LP) e não até umidade higroscópica como estabelecido pela norma; essas umidades iniciais dos ensaios de LL e LP foram determinadas por tentativas. Não foram preparadas amostras de lodo para realização do ensaio de compactação devido ao elevado teor de umidade natural do lodo.

As misturas de solo com lodo foram preparadas na proporção 3:1, 4:1 e 5:1 em massa úmida (solo:lodo). O solo foi previamente seco ao ar até umidade higroscópica $(\sim 1 \%)$ e o lodo foi utilizado na umidade in natura (variando de 330 a $350 \%$ ). As quantidades de solo e lodo correspondentes a cada proporção estabelecida foram misturadas manualmente até completa homogeneização (Figura 3.5 e Figura 3.6), obtendo-se assim misturas com teores de umidade distintos. A cada mistura, portanto, corresponde um teor de umidade de mistura. Para a análise granulométrica e determinação da massa específica dos grãos as amostras foram utilizadas na umidade de mistura e para os limites de consistência foi utilizada metodologia similar à empregada no caso do lodo (secagem até a umidade inicial do ensaio). Ensaios de compactação das misturas foram realizados utilizando-se amostras na umidade de mistura e amostras com secagem prévia. 
Figura 3.5 - Preparação de mistura solo-lodo.

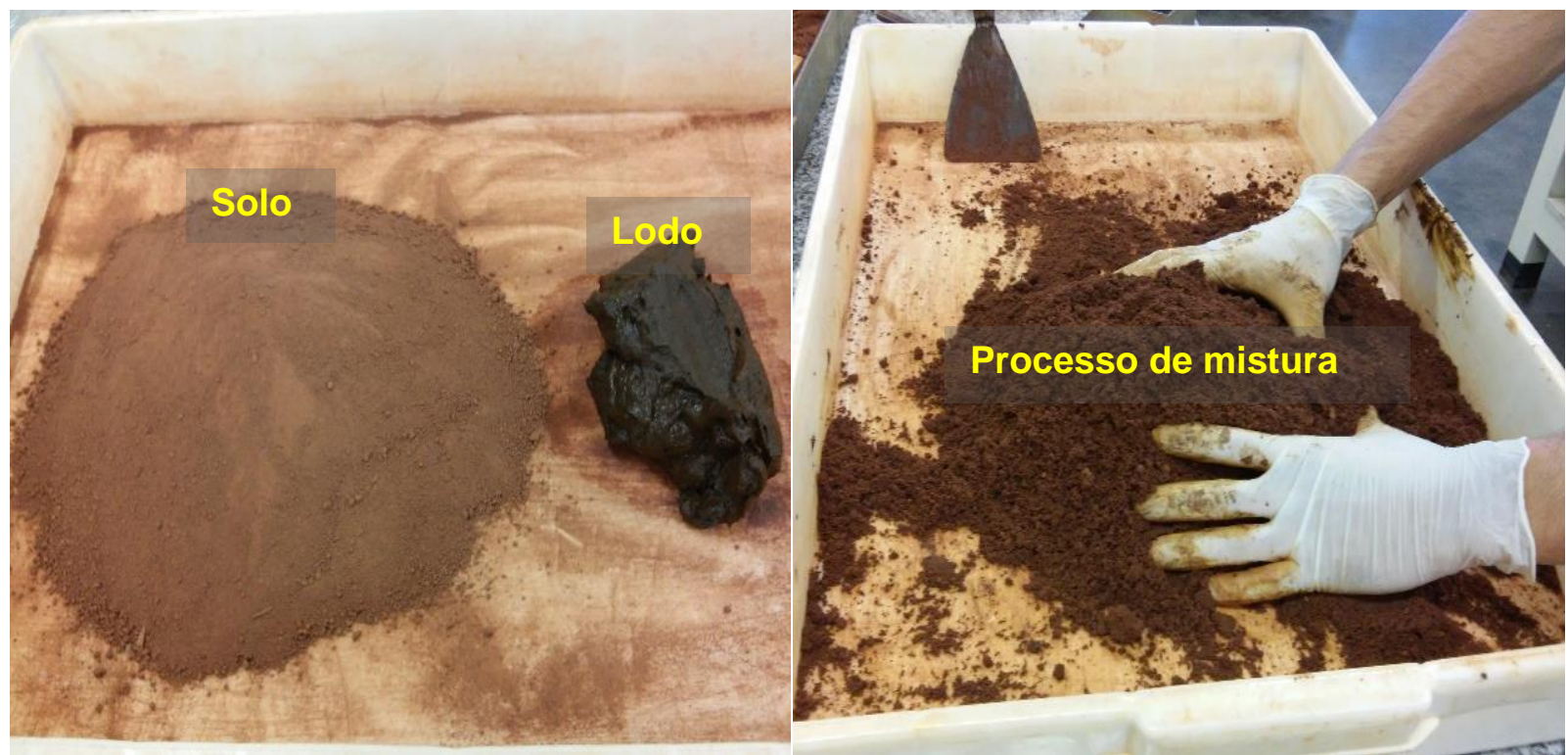

Fonte: Autor

Figura 3.6 - Mistura solo-lodo homogeneizada.

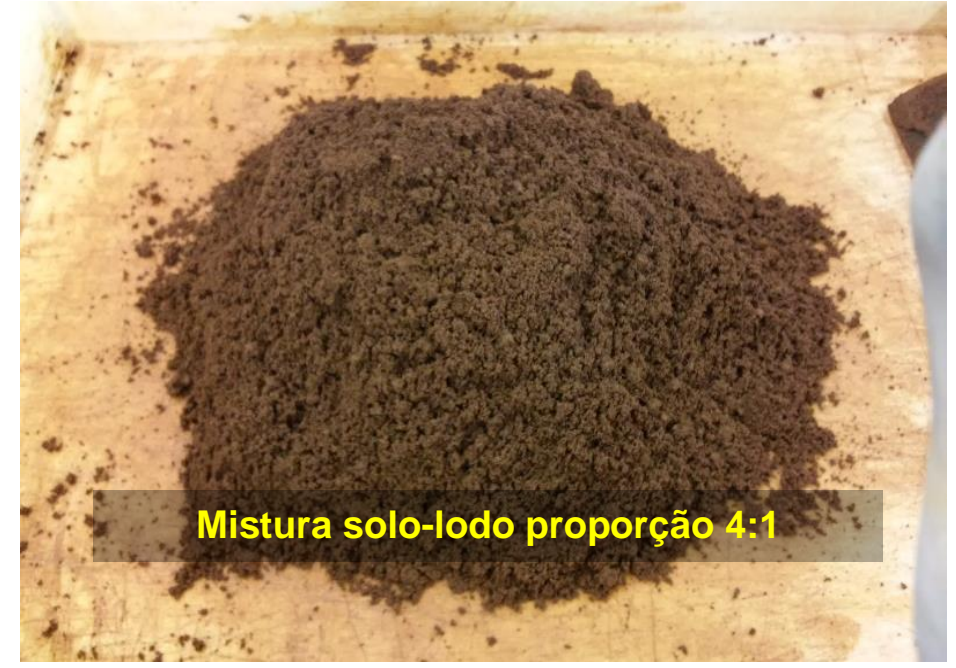

Fonte: Autor 


\subsubsection{Caracterização geotécnica dos materiais}

A caracterização geotécnica do solo, do lodo e das misturas foi realizada por meio de ensaios de análise granulométrica, limite de liquidez, limite de plasticidade e massa específica dos grãos de acordo com os métodos preconizados nas normas ABNT-NBR 7181/1988, ABNT-NBR 6459/1984, ABNT-NBR 7180/1988 e ABNT-NBR 6508/1984, respectivamente. Foram realizados dois ensaios de análise granulométrica por sedimentação com o lodo, o primeiro utilizando defloculante (125 $\mathrm{mL}$ de hexametafosfato de sódio), de acordo com a norma ABNT-NBR 7181/1988, e o segundo sem uso de defloculante, visando estudar o efeito de floculação dos produtos químicos presentes no lodo.

\subsubsection{Compactação do solo e das misturas}

As curvas de compactação do solo e das misturas foram determinadas através do ensaio de compactação na energia Proctor normal segundo a norma ABNT-NBR 7182/1988, utilizando amostras preparadas como descrito em 3.4.1, com distintos teores de umidade inicial.

\subsubsection{Preparação de corpos de prova para ensaios de deformabilidade, permeabilidade e resistência}

Foram compactados espécimes do solo e das misturas 3:1, 4:1 e 5:1 na energia Proctor Normal, o solo no teor de umidade ótimo e as misturas na umidade de mistura correspondente. A partir dos espécimes compactados foram moldados corpos de prova para os ensaios de deformabilidade, permeabilidade e resistência ao cisalhamento nas dimensões especificadas para cada ensaio.

\subsubsection{Deformabilidade do solo e das misturas}

A deformabilidade do solo e das misturas foi estudada por meio de ensaios de adensamento unidimensional segundo o método indicado pela norma ABNT-NBR 12007/1990. Os ensaios foram realizados em corpos de prova com diâmetro de 7,13 $\mathrm{cm}$ e $2,0 \mathrm{~cm}$ de altura, moldados a partir de espécimes preparados como especificado em 3.4.4. A Figura 3.7 mostra o equipamento utilizado nos ensaios de adensamento unidimensional. 
Figura 3.7 - Prensas e células de adensamento unidimensional.

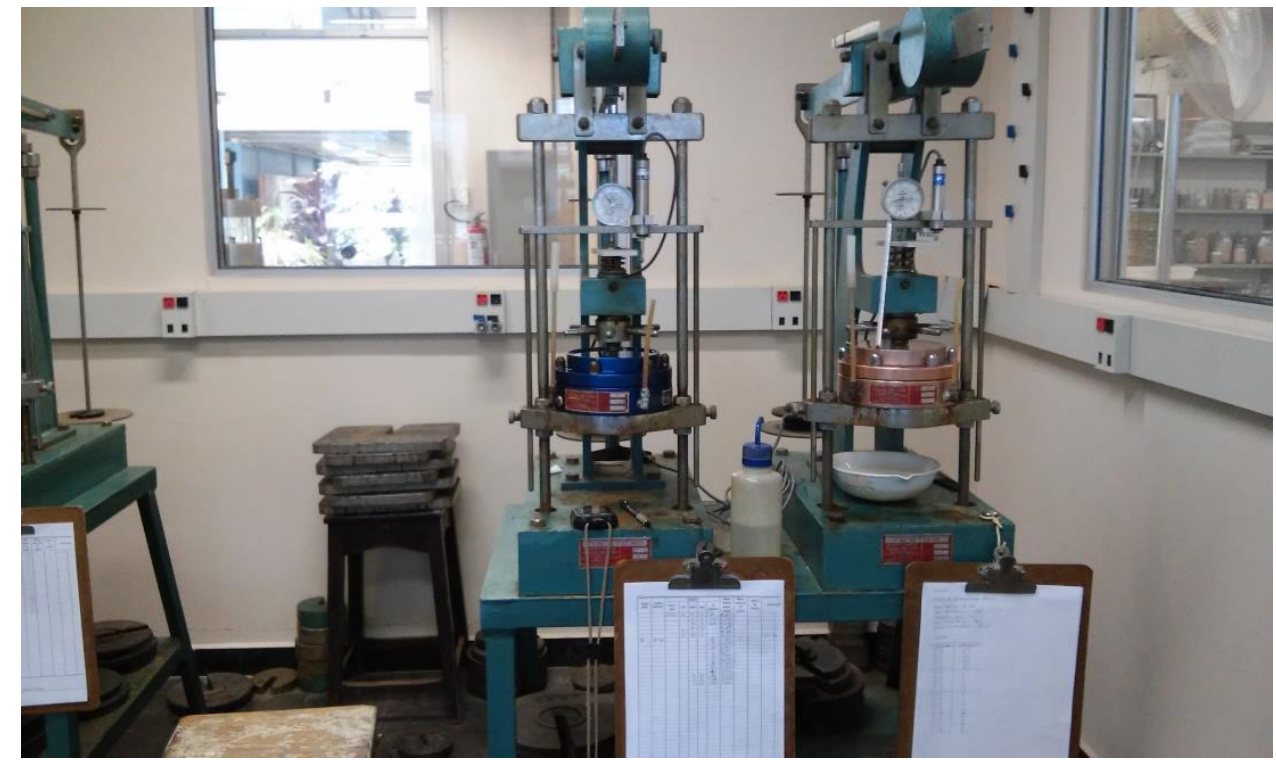

Fonte: Autor

\subsubsection{Permeabilidade do solo e das misturas}

Foram efetuados dois tipos de ensaios de permeabilidade: carga variável na célula de adensamento com tensão vertical de 40 a $1280 \mathrm{kPa}$; e carga constante na célula Triflex2, segundo a norma ASTM D5084-00, com tensão confinante de 30 e 60 $\mathrm{kPa}$ e gradiente hidráulico de 5 e 10.

Os ensaios foram realizados em corpos de prova com diâmetro de $8,0 \mathrm{~cm}$ e altura de $8,0 \mathrm{~cm}$, moldados a partir de espécimes compactados como especificado em 3.4.4. Na Figura 3.8 mostra-se a moldagem de um corpo de prova e o equipamento utilizado para realização do ensaio de permeabilidade de parede flexível. 
Figura 3.8 - Moldagem de corpo de prova e equipamento utilizado nos ensaios de permeabilidade de parede flexível.

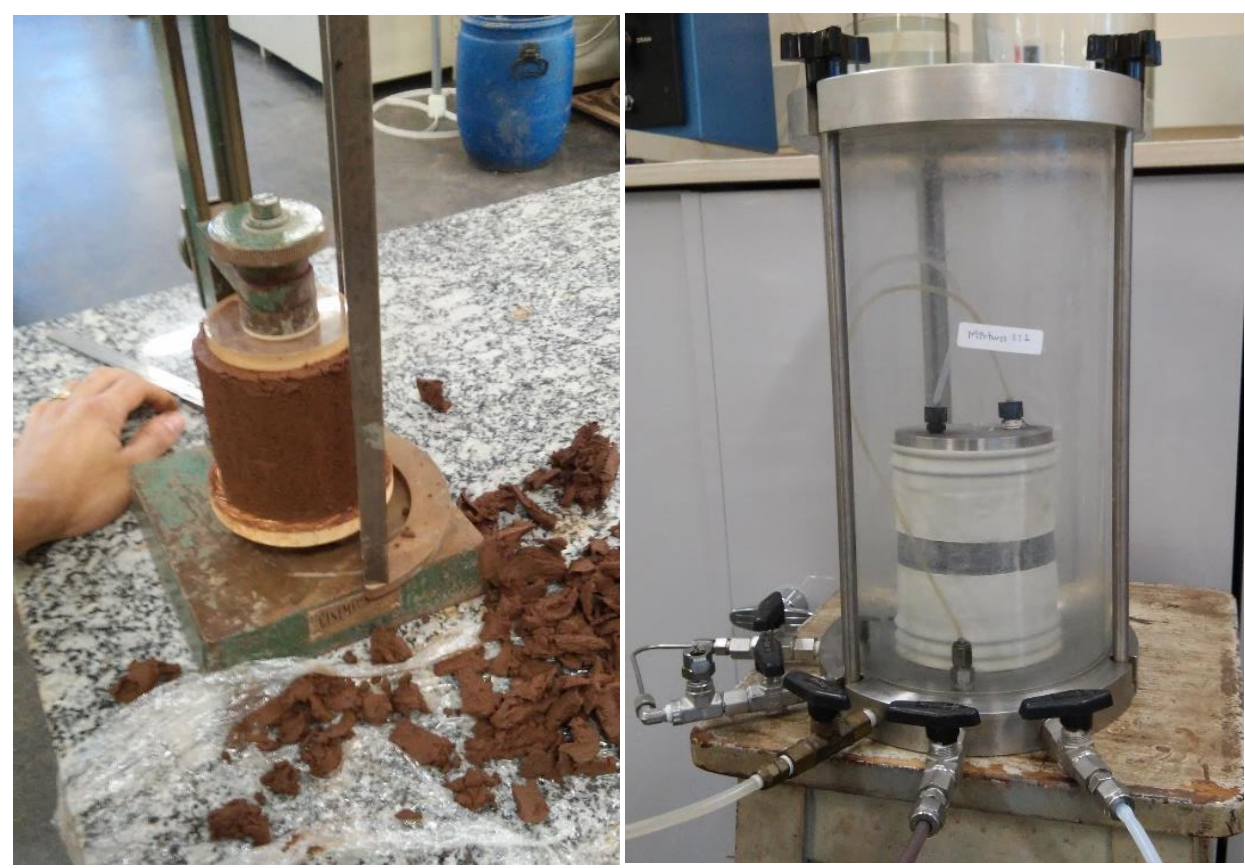

Fonte: Autor

\subsubsection{Resistência ao cisalhamento do solo e das misturas}

A resistência ao cisalhamento do solo e das misturas foi estudada por meio de ensaios de compressão triaxial do tipo adensado anisotropicamente não drenado com medida de pressão neutra (Anisotropicaly Consolidated Undrained, CAU), segundo a norma ASTM D4767-04. No adensamento anisotrópico foi utilizada uma razão de tensões (tensão horizontal / tensão vertical) de 0,80.

Os ensaios foram realizados em corpos de prova moldados a partir de espécimes compactados como especificado em 3.4.4. As dimensões dos corpos de prova foram: diâmetro de $3,8 \mathrm{~cm}$ e altura de $8,0 \mathrm{~cm}$.

O adensamento anisotrópico objetiva reproduzir condições de campo mais realistas, pois é conhecido que o estado de tensões no campo é geralmente anisotrópico, embora os ensaios triaxiais com adensamento isotrópico sejam mais difundidos. Donaghe and Townsend (1978) apontam que o adensamento é geralmente isotrópico nos ensaios triaxiais porque o adensamento anisotrópico 
requer procedimentos mais complicados e demanda mais tempo. Com o equipamento automaticamente controlado por software disponível nesta pesquisa, não havia motivo para não se realizar um ensaio em condições mais consistentes com as que geralmente ocorrem no campo.

O equipamento utilizado para realizar os triaxiais é provido de transdutores de deslocamento e pressão para controle da execução do ensaio e aquisição dos dados por meio de computador fazendo uso de software específico. As Figura 3.9 e Figura 3.10 mostram a montagem de um corpo de prova e o equipamento utilizado para realização dos ensaios triaxiais.

Figura 3.9 - Montagem de corpo de prova na câmera triaxial.

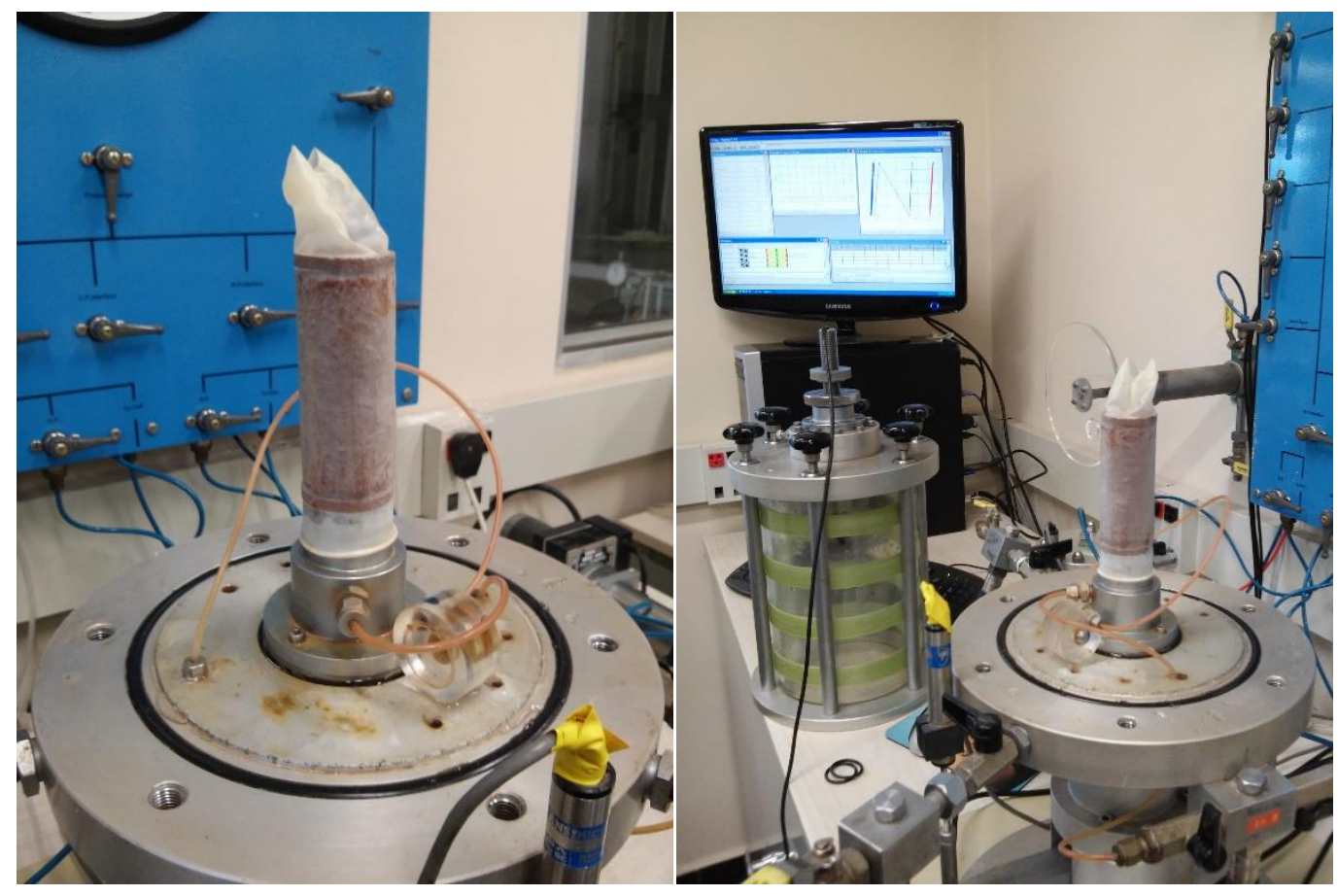

Fonte: Autor 
Figura 3.10 - Execução de ensaio de compressão triaxial adensado não drenado (CAU) com medida de pressão neutra.

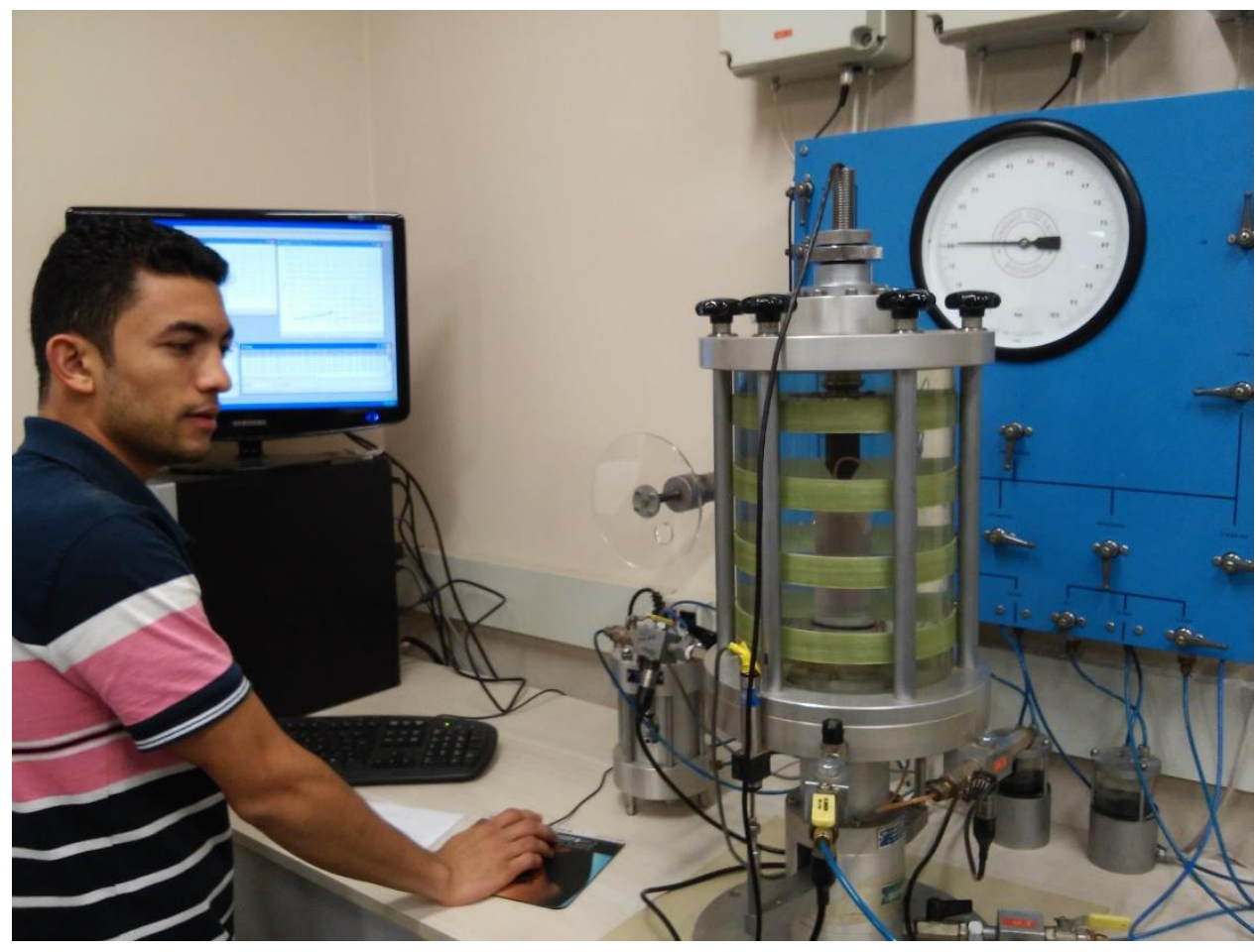

Fonte: Autor 


\section{RESULTADOS E DISCUSSÕES}

\subsection{CARACTERIZAÇÃO QUÍMICA E MINERALÓGICA}

\subsubsection{Caracterização química do solo}

A caracterização química do solo foi apresentada em 3.3.1.

\subsubsection{Caracterização mineralógica do solo}

A caracterização mineralógica do solo foi apresentada em 3.3.2.

\subsubsection{Caracterização química do lodo}

Na Tabela 4.1 são apresentados os resultados obtidos nas análises químicas do lodo. O valor do $\mathrm{pH}$ do lodo apresentou um valor ao redor de 7, o que indica que o lodo é neutro. Esse valor de $\mathrm{pH}$ do lodo concorda com os valores $\mathrm{pH}$ determinados na bibliografia para outros lodos de ETA, que em geral variam de 6 a 8 , conforme apresentado no item 2.5. O maior valor de $\mathrm{pH}$ obtido com água em relação ao obtido com solução de $\mathrm{KCl}$ indica a prevalência de cargas superficiais negativas.

Tabela 4.1 - Resultados das análises químicas do lodo.

\begin{tabular}{|c|c|}
\hline Parâmetro & Valor \\
\hline $\mathrm{pH}\left(\mathrm{em} \mathrm{H} \mathrm{H}_{2} \mathrm{O}\right)$ & 7,2 \\
\hline $\mathrm{pH}$ (em solução de $\mathrm{KCl} 1 \mathrm{~mol} \cdot \mathrm{L}^{-1}$ ) & 6,7 \\
\hline$P\left(m g \cdot \mathrm{kg}^{-1}\right)$ & 1 \\
\hline $\mathrm{Na}\left(\mathrm{mg} \cdot \mathrm{kg}^{-1}\right)$ & 5 \\
\hline $\mathrm{K}\left(\mathrm{mmolc} \cdot \mathrm{kg}^{-1}\right)$ & 1,2 \\
\hline $\mathrm{Ca}\left(\mathrm{mmolc} . \mathrm{kg}^{-1}\right)$ & 226 \\
\hline $\mathrm{Mg}\left(\mathrm{mmolc} . \mathrm{kg}^{-1}\right)$ & 20 \\
\hline $\mathrm{Al}\left(\mathrm{mmolc} . \mathrm{kg}^{-1}\right)$ & $<1$ \\
\hline $\mathrm{H}^{+}+\mathrm{Al}^{3+}\left(\right.$ mmolc. $\left.\mathrm{kg}^{-1}\right)$ & $<10$ \\
\hline Soma de bases trocáveis (mmolc. $\mathrm{kg}^{-1}$ ) & 252,2 \\
\hline CTC (mmolc. $\left.\mathrm{kg}^{-1}\right)$ & 255,2 \\
\hline Saturação da CTC por bases (\%) & 99 \\
\hline Saturação por alumínio (\%) & 0 \\
\hline Matéria orgânica $(\mathrm{g} / \mathrm{kg})$ & 26 \\
\hline Carbono orgânico $(\mathrm{g} / \mathrm{kg})$ & 15 \\
\hline
\end{tabular}


Chama a atenção a elevada concentração de cálcio (Ca), no entanto comum em lodos de ETA devido ao uso de cal no processo de tratamento da água. A significativa concentração de magnésio $(\mathrm{Mg})$ pode também ser devida ao uso de cal magnesiana.

O valor da capacidade de troca catiônica (CTC) foi de 255,2 mmolc/kg (25,52 cmolc/kg), muito maior do que o determinado para o solo de Botucatu, de 23,4 mmolc/kg (2,34 cmolc/kg). Segundo o IBGE (2007), solos com CTC maior do que 270 mmolc/kg (27,0 cmolc/kg) são considerados solos de atividade alta. Fadigas et al. (2002) determinaram a CTC de 162 solos argilosos brasileiros e mostraram que 79\% dos solos investigados apresentavam valores de CTC menores do que $100 \mathrm{mmolc} / \mathrm{kg}$ $(10,0 \mathrm{cmolc} / \mathrm{kg})$.

O valor da CTC determinado para o lodo encontra-se dentro da faixa de valores obtidos para outros lodos de ETA: entre 22,96 a 135,75 cmolc/kg segundo Hsieh e Raghu (1997) e entre 13,6 e 56 cmolc/kg segundo Dayton e Basta (2001).

A capacidade de troca de cátions (CTC) de um material representa a quantidade total de cátions retidos à superfície das partículas componentes do material em condição permutável $\left(\mathrm{Ca}^{2+}+\mathrm{Mg}^{2+}+\mathrm{K}^{+}+\mathrm{H}^{+}+\mathrm{Al}^{3+}\right)$. Por sua vez, a soma de bases trocáveis é a soma dos cátions permutáveis exceto $\mathrm{H}^{+}$e $\mathrm{Al}^{3+}$, ou seja, dos cátions essenciais à nutrição das plantas $\left(\mathrm{Ca}^{2+}+\mathrm{Mg}^{2+}+\mathrm{K}^{+}\right)$. A soma de bases trocáveis do lodo é $252,2 \mathrm{mmolc} / \mathrm{kg}(25,22 \mathrm{cmolc} / \mathrm{kg})$, equivalente a 98,8\% da CTC, enquanto a do solo é de $1,8 \mathrm{mmolc} / \mathrm{kg}(0,18 \mathrm{cmolc} / \mathrm{kg})$, indicando que grande parte da CTC do solo $\left(23,4\right.$ mmolc/kg ou 2,34 cmolc/kg) está ocupada por $\mathrm{H}^{+}$e $\mathrm{Al}^{3+}$.

A CTC dos solos encontra-se aproximadamente entre 3,5 e 35,6 cmolc/kg (BRADY; WEIL, 2008) e a matéria orgânica varia de 100 a $400 \mathrm{cmolc} / \mathrm{kg}$ (FOTH, 1991). Porém, o lodo apresentou um baixo teor de matéria orgânica, portanto não se pode afirmar que o elevado valor da CTC do lodo seja devido à matéria orgânica.

O teor de matéria orgânica determinado foi de $26 \mathrm{~g} / \mathrm{kg}$, o dobro do valor obtido para o solo, porém, ainda assim é um teor de matéria orgânica considerado muito baixo (HAZELTON; MURPHY, 2007). 
$\mathrm{Na}$ Tabela 4.2 são apresentados os resultados das análises de fluorescência de raios $X$. Os compostos químicos com maior concentração foram $\mathrm{Fe}_{2} \mathrm{O}_{3}(46,0 \%)$, $\mathrm{SiO}_{2}(18,3 \%)$ e $\mathrm{Al}_{2} \mathrm{O}_{3}(8,89 \%)$.

A elevada concentração de ferro pode ser em grande medida devida ao cloreto férrico adicionado no processo de tratamento da água e à composição química dos minerais constituintes do lodo. A presença de alumínio pode ser devida aos minerais muscovita e caulinita (Tabela 4.3). A sílica pode ser explicada pela presença de quartzo como mineral constituinte do lodo. O quartzo também foi observado em todos os lodos de ETA estudados por outros autores (Tabela 2.4).

Tabela 4.2 - Resultados da análise de fluorescência de raios $X$ do lodo.

\begin{tabular}{cccc}
\hline $\begin{array}{c}\text { Composto } \\
\text { químico }\end{array}$ & $\begin{array}{c}\text { Teor normalizado do } \\
\text { composto químico (\%) }\end{array}$ & $\begin{array}{c}\text { Composto } \\
\text { químico }\end{array}$ & $\begin{array}{c}\text { Teor normalizado do } \\
\text { composto químico (\%) }\end{array}$ \\
\hline $\mathrm{Na}_{2} \mathrm{O}$ & 0,100 & $\mathrm{MnO}$ & 0,210 \\
$\mathrm{MgO}$ & 0,438 & $\mathrm{Fe}_{2} \mathrm{O}_{3}$ & 46,0 \\
$\mathrm{Al}_{2} \mathrm{O}_{3}$ & 8,89 & $\mathrm{NiO}$ & 0,152 \\
$\mathrm{SiO}_{2}$ & 18,3 & $\mathrm{CuO}$ & 0,117 \\
$\mathrm{P}_{2} \mathrm{O}_{5}$ & 0,249 & $\mathrm{ZnO}$ & 0,020 \\
$\mathrm{SO}_{3}$ & 0,236 & $\mathrm{Y}_{2} \mathrm{O}_{3}$ & 0,034 \\
$\mathrm{Cl}$ & 0,129 & $\mathrm{ZrO}_{2}$ & 0,014 \\
$\mathrm{~K} 2 \mathrm{O}$ & 1,00 & $\mathrm{Nb}_{2} \mathrm{O}_{5}$ & - \\
$\mathrm{CaO}$ & 1,59 & $\mathrm{PbO}$ & 0,011 \\
$\mathrm{TiO}_{2}$ & 0,417 & $\mathrm{Ta}_{2} \mathrm{O}_{5}$ & - \\
$\mathrm{V}_{2} \mathrm{O}_{5}$ & 0,010 & $\mathrm{PF}$ & 22,0 \\
$\mathrm{Cr}_{2} \mathrm{O}_{3}$ & 0,024 & - & - \\
\hline $\mathrm{PF}=$ perda ao fogo & & &
\end{tabular}

\subsubsection{Caracterização mineralógica do lodo}

O difratograma obtido da análise de difração de raios $X$ do lodo é apresentado na Figura 4.1 e as fases cristalinas identificadas no difratograma são apresentadas na Figura 4.2. A partir das fases cristalinas identificadas foram determinados os minerais presentes na amostra de lodo: quartzo, goethita, muscovita e caulinita, cujas formulas químicas são apresentados na Tabela 4.3. Esses minerais estão presentes 
nos solos residuais de granitos e gnaisses da Serra do Mar, em cuja vertente atlântica se localiza o Rio Cubatão.

Tabela 4.3 - Composição mineralógica do lodo.

\begin{tabular}{cc}
\hline Mineral & Formula \\
\hline Quartzo & $\mathrm{SiO}_{2}$ \\
Goethita & $\mathrm{FeO}(\mathrm{OH})$ \\
Muscovita & $\mathrm{KAl}_{2}\left(\mathrm{AlSi}_{3} \mathrm{O}_{10}\right)(\mathrm{OH})_{2}$ \\
Caulinita & $\mathrm{Al}_{2} \mathrm{Si}_{2} \mathrm{O}_{5}(\mathrm{OH})_{4}$ \\
\hline
\end{tabular}

Figura 4.1 - Difratograma de raios $X$ do lodo.

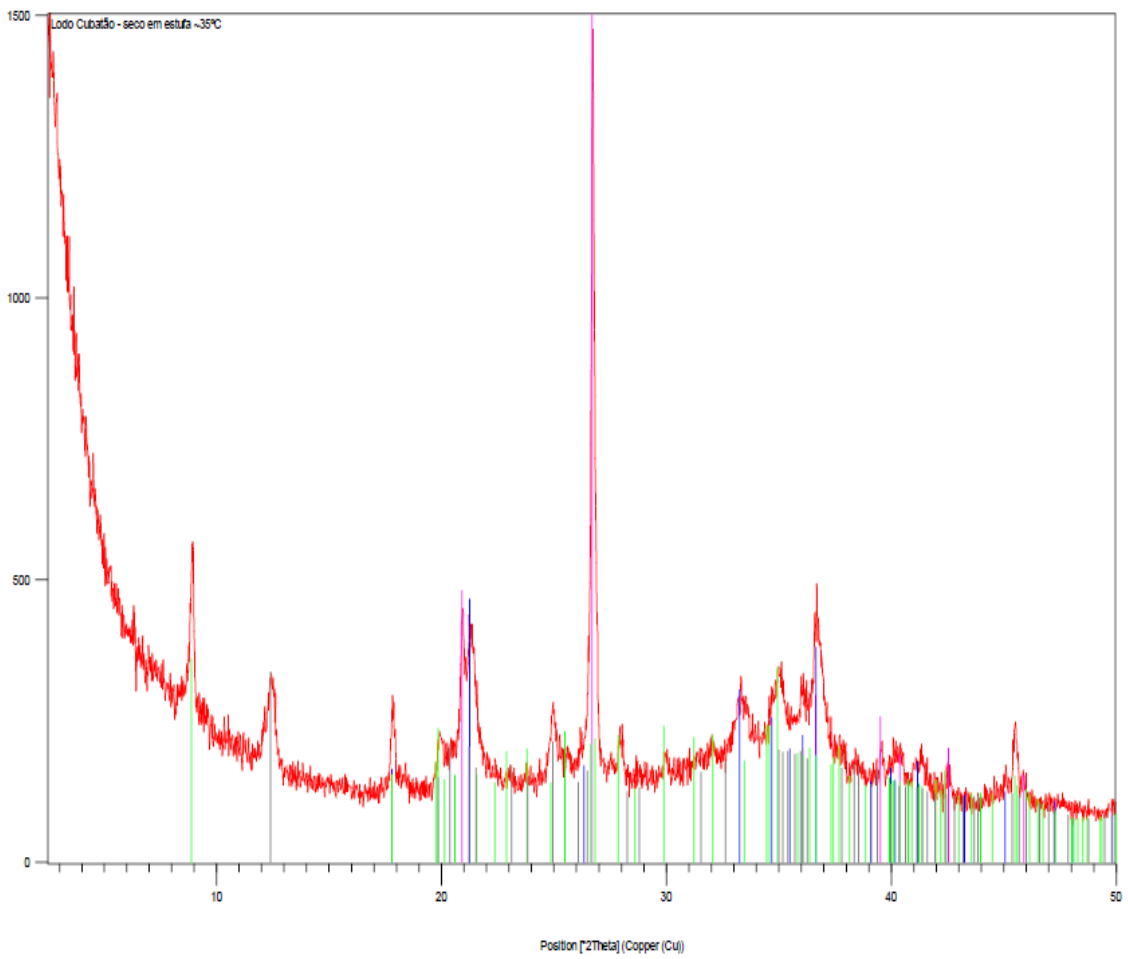


Figura 4.2 - Fases identificadas no difratograma de raios $\mathrm{X}$ do lodo.

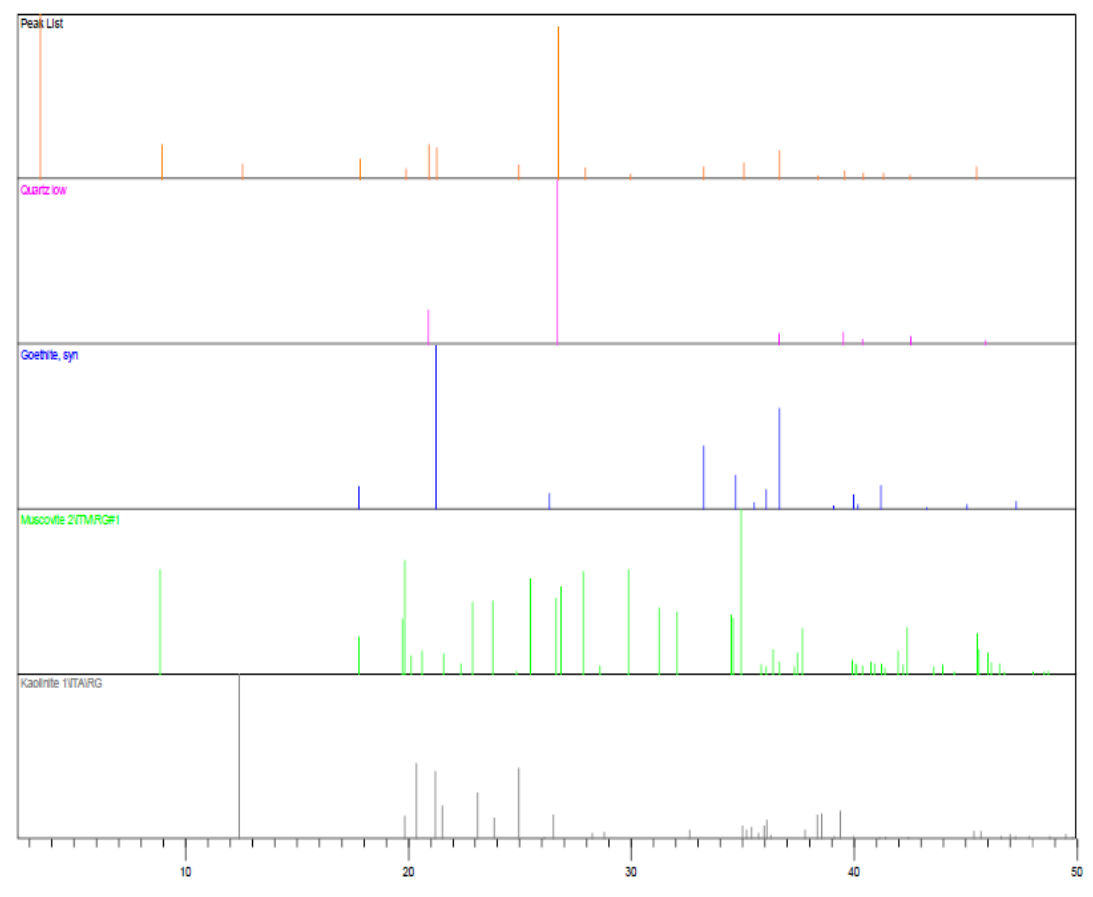

Nas Figuras 4.3 a 4.5 são apresentadas algumas das imagens obtidas no MEV. Nas Figuras 4.3 e 4.4 podem ser observadas partículas com formato lamelar, muito provavelmente partículas dos minerais caulinita ou muscovita.

Na Figura 4.5 consta um exemplo de partículas nas quais foram feitas análises químicas pontuais por EDS, cujos resultados estão apresentados na Figura 4.6. Os pontos analisados indicaram a presença de $\mathrm{Si}, \mathrm{O}, \mathrm{Al}, \mathrm{Fe}, \mathrm{K}, \mathrm{Ca}$ e $\mathrm{Mg}$, o que concorda com a composição mineralógica do lodo determinada nas análises de difração de raios $\mathrm{X}$ e com as análises químicas. 
Figura 4.3 - Partículas de lodo vistas no Microscópio Eletrônico de Varredura (MEV) a 40000x.

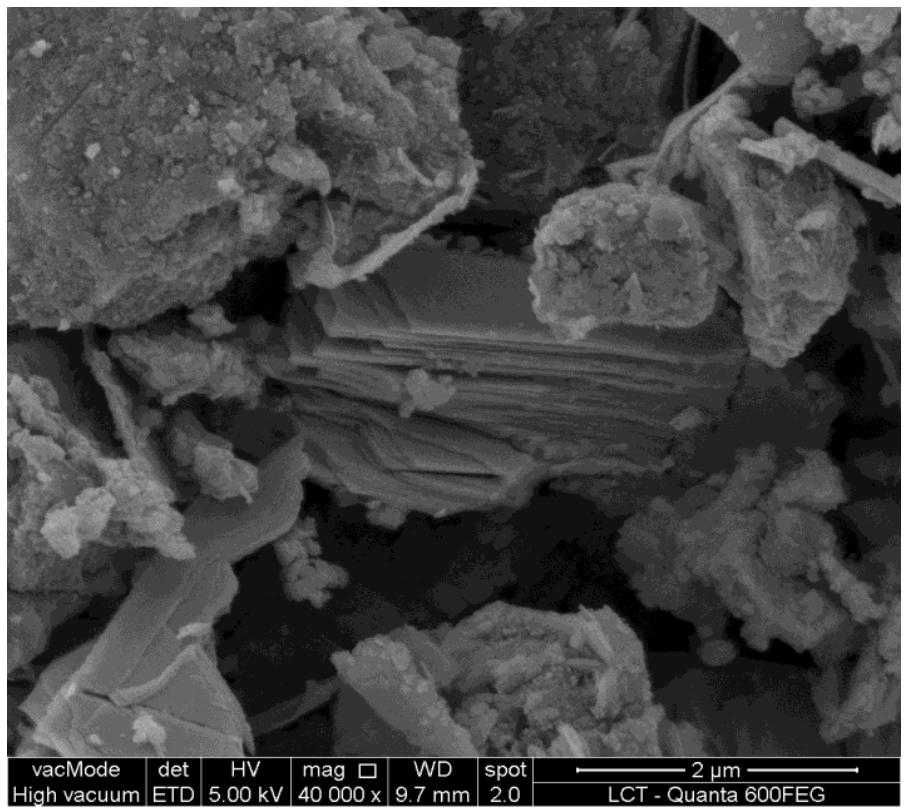

Figura 4.4 - Partículas de caulinita presentes no lodo vistas no Microscópio Eletrônico de Varredura (MEV).

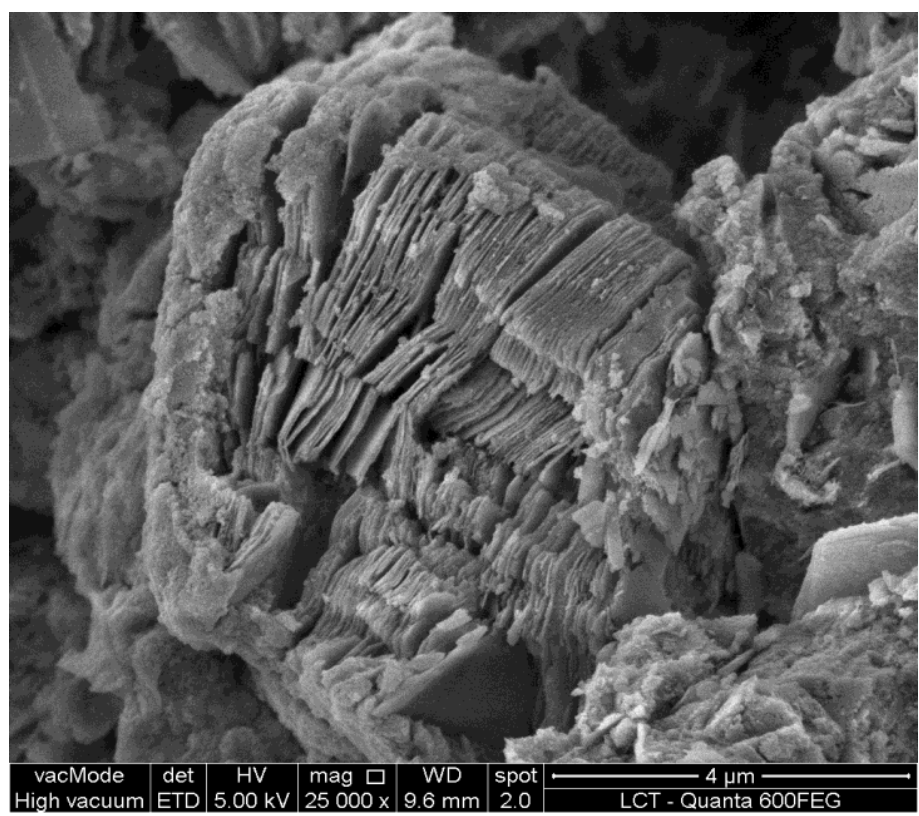


Figura 4.5 - Análise química das partículas de lodo por EDS.

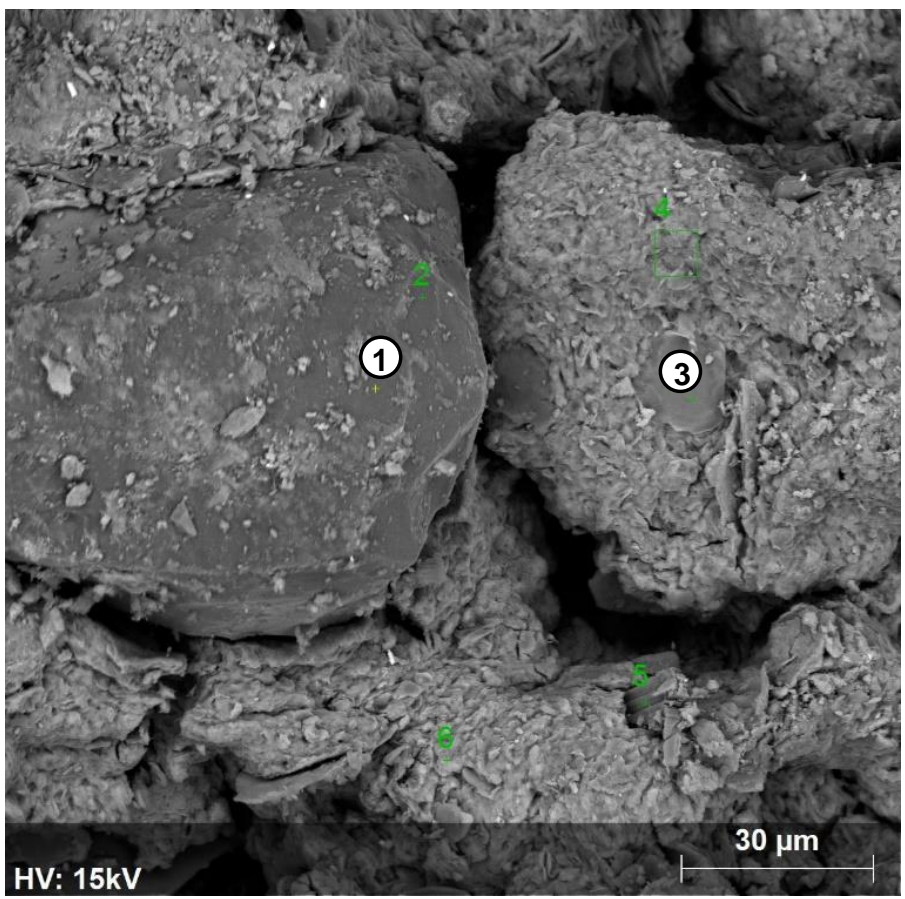

Figura 4.6 - Espectros de análises químicas pontuais (EDS).
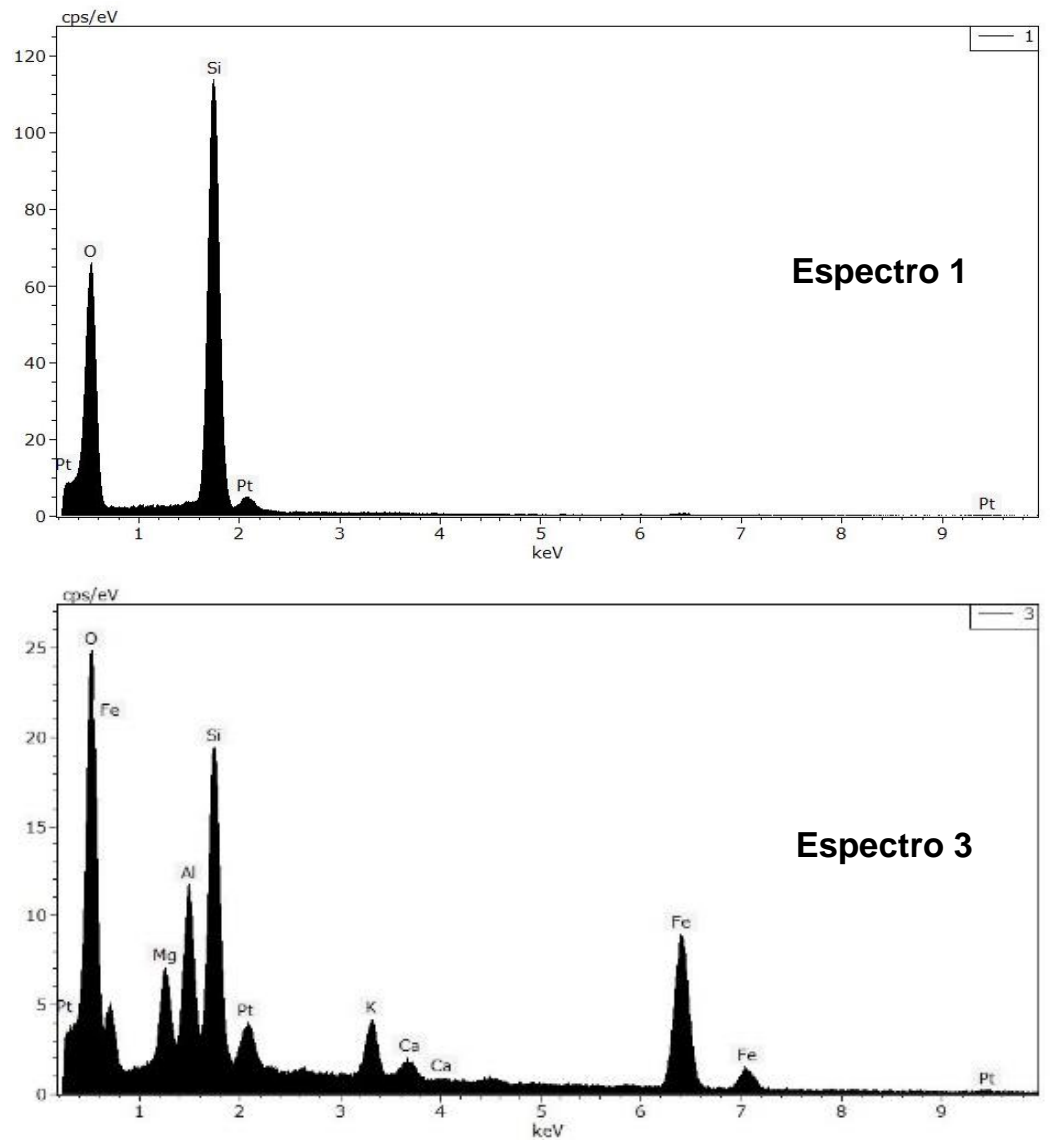


\subsection{ENSAIOS GEOTÉCNICOS COM O SOLO, O LODO E AS MISTURAS}

\subsubsection{Caracterização geotécnica dos materiais}

Para a caracterização geotécnica do solo, do lodo e das misturas foram realizados os ensaios de análise granulométrica, limite de liquidez, limite de plasticidade e massa específica dos grãos.

\subsubsection{Caracterização geotécnica do solo}

De acordo com norma ABNT-NBR 7181/1988, a distribuição granulométrica foi obtida por sedimentação e peneiramento do material lavado na peneira \#200 (0,075 $\mathrm{mm}$ ) após o ensaio de sedimentação, pois 100\% do material passou na peneira \#4 $(4,75 \mathrm{~mm})$. As curvas granulométricas do solo da primeira e segunda coleta estão apresentadas na Figura 4.7. As porcentagens de material em massa seca para as distintas frações do solo da primeira coleta foram: $2,6 \%$ de areia grossa, 48,4\% de areia média, 22,9\% de areia fina, 3,0\% de silte, e 23,2\% de argila. As porcentagens para o solo da segunda coleta foram: $2,2 \%$ de areia grossa, 42,6\% de areia média, $25,6 \%$ de areia fina, $5,1 \%$ de silte, e $24,4 \%$ de argila. As amostras das duas coletas têm, portanto, distribuição granulométrica muito semelhante.

Os valores dos limites de consistência obtidos para o solo da primeira coleta foram limite de liquidez (LL) de $25 \%$ e limite de plasticidade (LP) de 14\%, resultando consequentemente o índice de plasticidade (IP) num valor de $11 \%$. Para o solo da segunda coleta foram obtidos valores de LL de $31 \%$, LP de $16 \%$, e IP de $15 \%$. As diferenças entre os limites de consistência do solo da primeira e segunda coleta foram relativamente baixas e podem ser explicadas por variações experimentais próprias do ensaio.

De acordo com a granulometria e os limites de consistência, o solo é classificado como uma areia argilosa (SC) segundo o Sistema Unificado de Classificação dos Solos (SUCS).

Foi determinado um valor da massa específica dos grãos de 2,690 g/cm³ muito próximo ao valor determinado por Zanon (2014), de 2,685 g/cm³. 


\subsubsection{Caracterização geotécnica do lodo}

Dado que o lodo é constituído por material fino, passando todo na peneira 4,75 $\mathrm{mm}$, a análise granulométrica consistiu de ensaio de sedimentação e peneiramento do material lavado e retido na peneira \#200 após o ensaio de sedimentação.

Para a obtenção da curva de distribuição granulométrica é necessária a determinação da massa específica dos grãos. Foram realizados diversos ensaios para determinar a massa específica dos grãos do lodo, obtendo-se sempre valores diferentes, variando de 2,850 a $2,950 \mathrm{~g} / \mathrm{cm}^{3}$. Acredita-se que isso tenha ocorrido devido à dificuldade de extração do ar da amostra durante o ensaio, pois o lodo é constituído de partículas muito finas. Esses valores de massa específica dos grãos são muito maiores do que aqueles típicos para solos $\left(2,60\right.$ a 2,70 g/ $\left.\mathrm{cm}^{3}\right)$, provavelmente devido à presença de ferro (densidade de $7,847 \mathrm{~g} / \mathrm{cm}^{3}$ ), adicionado no cloreto férrico utilizado no tratamento da água, assim como muito maiores do que os apresentados por Vandermeyden e Cornwell (1998) (Tabela 2.9).

As porcentagens de material das distintas frações em massa seca para o ensaio com uso de defloculante foram: $1,2 \%$ de areia média, 4,7\% de areia fina, $25,7 \%$ de silte, e $68,4 \%$ de argila. Fica evidente que o lodo em estudo é constituído principalmente por partículas finas $(94,1 \%$ de finos).

Os valores dos limites de consistência obtidos foram de $239 \%$ para LL e de $81 \%$ para LP, resultando consequentemente o índice de plasticidade de $158 \%$. Wang et al. (1992) reportaram valores de LL para lodos de ETA de 108\%, 550\% e 423\%, enquanto O'Kelly (2008) determinou LL de um lodo de ETA na ordem de $490 \%$. Em geral os lodos de ETA apresentam valores de LL e IP muito altos, como os valores obtidos para o lodo em estudo. Observa-se também que o lodo desaguado na centrífuga apresenta teor de umidade (umidade in natura) superior ao limite de liquidez.

De acordo com a granulometria e os limites de consistência obtidos, o lodo é classificado como um silte de alta compressibilidade $(\mathrm{MH})$ segundo o SUCS.

Na Figura 4.7 são apresentadas as curvas granulométricas do lodo, com uso e sem uso de defloculante. Pode ser observada a grande influência do cloreto férrico (coagulante utilizado no processo de tratamento da água), fazendo com que as 
partículas se aglutinem e precipitem mais rapidamente, o que resulta em uma porcentagem maior de areia e menor de argila.

Figura 4.7 - Curvas granulométricas do solo, do lodo e das misturas.

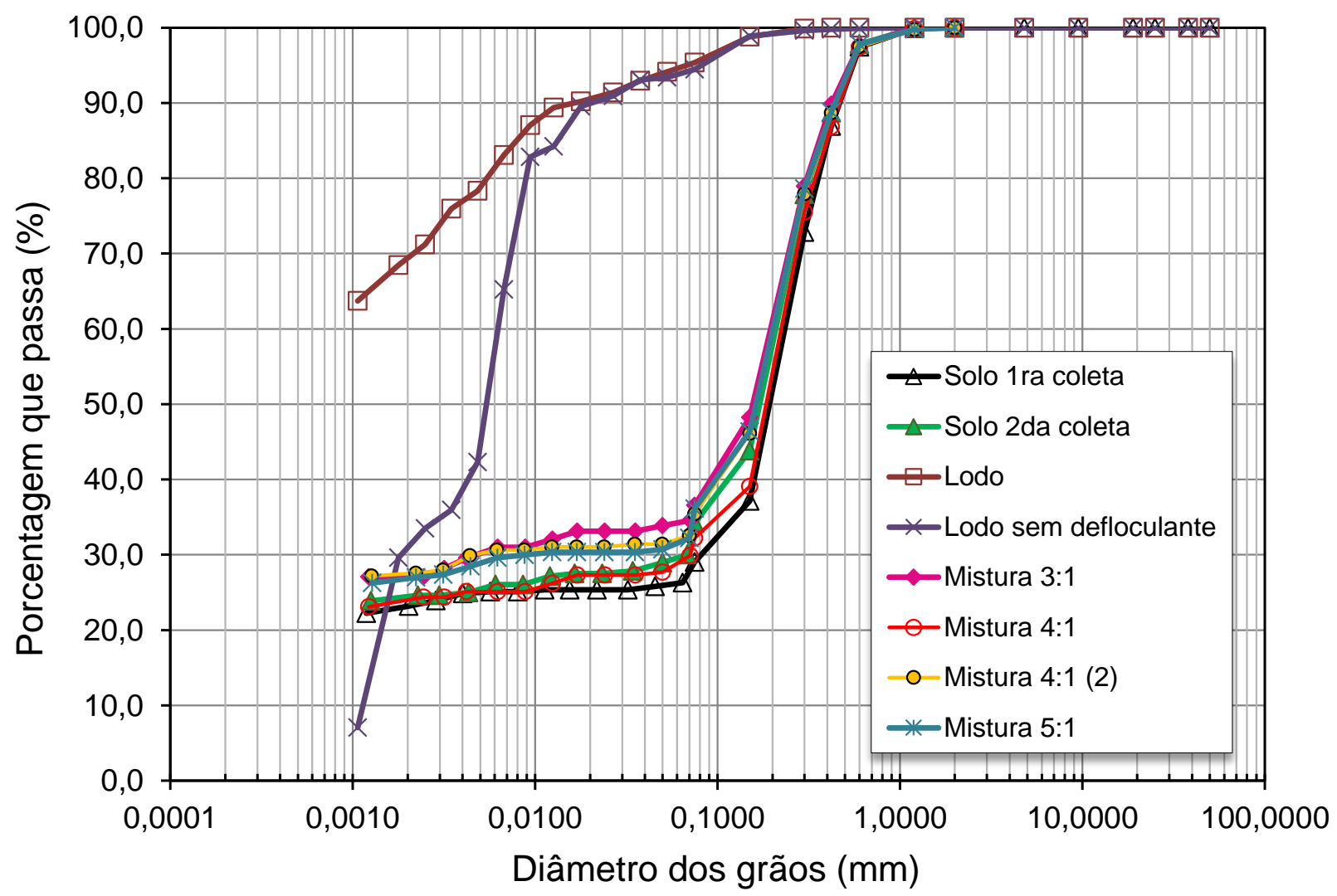

Foi realizada secagem do lodo ao ar em temperatura ambiente de aproximadamente $25 \stackrel{\circ}{\circ}$ com o objetivo de avaliar se o lodo se converte em um material não plástico ou se sua granulometria se altera, como reportado por Hsieh e Raghu (1997) e Watanabe et al. (2011). A Figura 4.8 mostra a variação do teor de umidade ao longo do tempo. A umidade inicial do lodo era 300\%; após 7 dias de secagem o lodo tinha um teor de umidade de 194\%, 92\% após 15 dias, 16\% após 32 dias, chegando a um valor constante de 14\% após 40 dias de secagem.

O lodo demorou um tempo relativamente elevado para poder atingir um teor de umidade constante (14\%). Essa água residual só pode ser removida por outros meios de secagem, como o uso de estufa. Outro aspecto importante a ressaltar é que o lodo se transformou em um material não plástico e sua granulometria mudou 
significativamente, tornando-se material granular com fração predominante de pedregulho, muito difícil de quebrar ou destorroar, como é mostrado na Figura 4.9.

Rodriguez et al. (2011) secaram um lodo de ETA em leitos de secagem, conseguindo teores de umidade ao redor de 15\% com 15 dias, e o lodo nessa umidade também se apresentou como um material granular com diâmetro de pedregulho.

Figura 4.8 - Variação do teor de umidade do lodo na secagem ao ar.

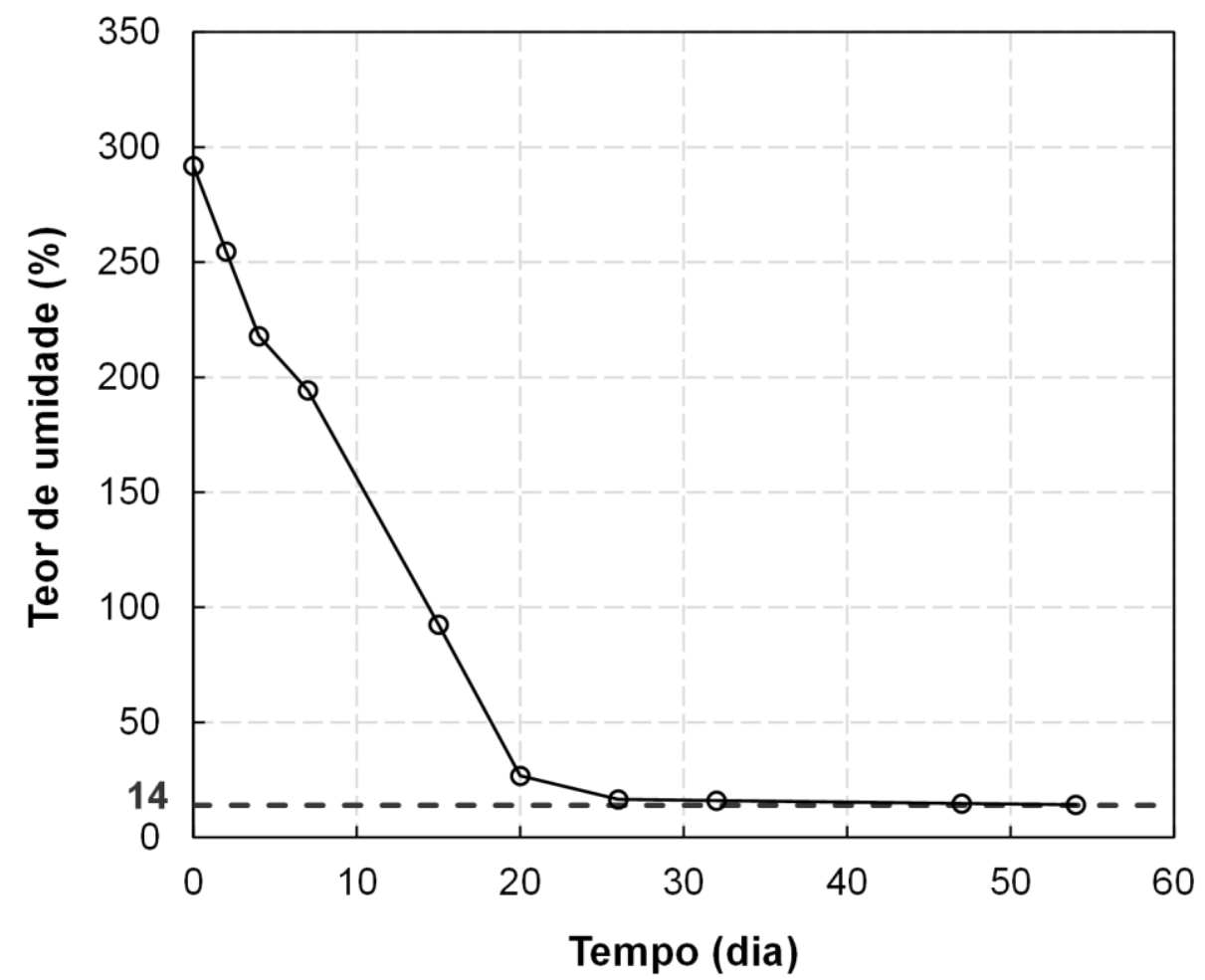

Durante a secagem, as partículas do lodo se aglutinaram e formaram partículas maiores aparentemente cimentadas, sendo muito difícil destorroá-las ou quebrá-las. Presume-se que a cimentação das partículas seja devida às complexas interações dos compostos químicos com as partículas durante a secagem.

\subsubsection{Caracterização geotécnica das misturas}

As curvas granulométricas das misturas solo-lodo nas proporções 3:1, 4:1 e 5:1 são apresentadas na Figura 4.7. As misturas solo-lodo foram realizadas com a amostra de solo da segunda coleta. Com a amostra de solo da primeira coleta foi realizada apenas uma mistura na proporção 4:1. Pode-se observar que a distribuição 
granulométrica das misturas é muito semelhante à do solo, mostrando apenas um pequeno incremento nas frações silte e argila. Esse incremento foi levemente maior para a mistura 3:1, que é a mistura com maior teor de lodo.

Figura 4.9 - Amostra de lodo prévio e após secagem ao ar.

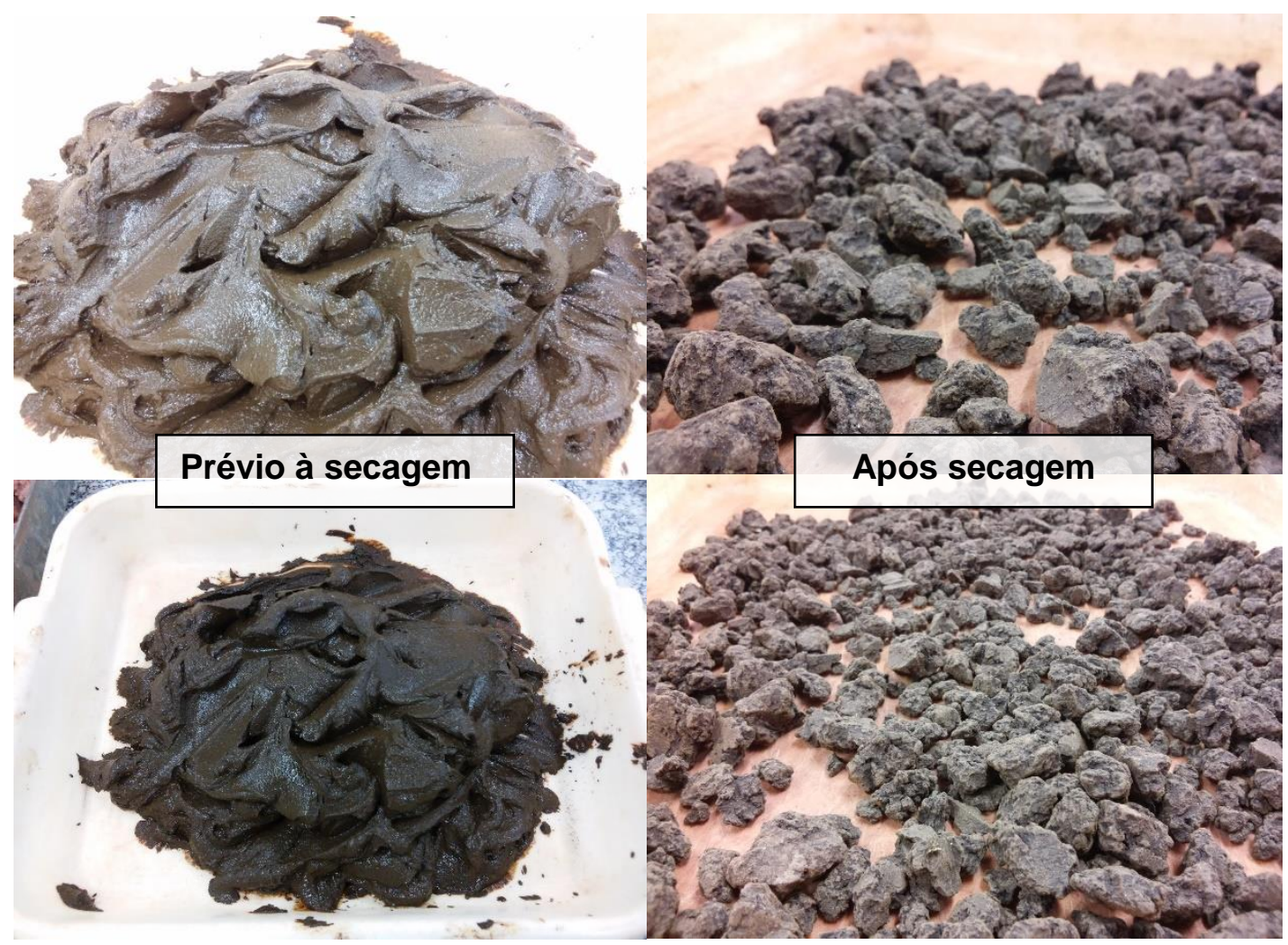

As porcentagens de material em massa seca para as frações de areia grossa, areia média, areia fina, silte, e argila das misturas e do solo são apresentados na

Tabela 4.4. Na mesma tabela, encontram-se os limites de consistência das misturas, os quais não apresentaram diferenças significativas em relação aos do solo. De acordo com a granulometria e limites de consistência, todas as misturas são classificadas como areia argilosa (SC) segundo o SUCS, exatamente a mesma classificação dada ao solo.

Foram determinados valores de massa específica dos grãos das misturas 3:1, $4: 1$ e $5: 1$ de $2,706,2,701$ e $2,686 \mathrm{~g} / \mathrm{cm}^{3}$, respectivamente.

Inicialmente, para a mistura 4:1 com a amostra de solo da primeira coleta, foram realizados diversos ensaios e a massa específica dos grãos variou entre 2,446 e $2,643 \mathrm{~g} / \mathrm{cm}^{3}$, valores menores que os determinados para o solo $\left(2,690 \mathrm{~g} / \mathrm{cm}^{3}\right)$ e o 
lodo (2,850 a 2,950 $\left.\mathrm{g} / \mathrm{cm}^{3}\right)$, sugerindo que a adição de lodo ao solo resultou em uma maior quantidade de ar aprisionado em flocos ou torrões que não pode ser retirado pelos procedimentos do ensaio (repouso em água destilada, utilização de aparelho dispersor e aplicação de vácuo). Os ensaios posteriores com as misturas efetuadas a partir da amostra de solo da segunda coleta deram melhores resultados, possivelmente devido ao maior tempo de aplicação do vácuo.

$\mathrm{Na}$ Tabela 4.4 é apresentado um resumo dos resultados dos ensaios de caracterização do solo, do lodo e das misturas para a comparação dos resultados.

Tabela 4.4 - Resumo dos resultados da caracterização geotécnica dos materiais.

\begin{tabular}{|c|c|c|c|c|c|c|c|}
\hline Parâmetro & $\begin{array}{l}\text { Solo (1a } \\
\text { coleta) }\end{array}$ & $\begin{array}{l}\text { Solo }\left(2^{a}\right. \\
\text { coleta) }\end{array}$ & Lodo & M3:1 $1^{(1)}$ & M4:1 $1^{(2)}$ & M4:1 (2) ${ }^{(1)}$ & M5: $1^{(1)}$ \\
\hline Argila (\%) & 23,2 & 24,4 & 69,3 & 27,1 & 24,0 & 27,5 & 26,8 \\
\hline Silte (\%) & 3,0 & 5,1 & 25,2 & 7,1 & 4,0 & 4,5 & 4,7 \\
\hline Areia fina (\%) & 22,9 & 25,6 & 4,6 & 24,3 & 23,0 & 24,7 & 25,6 \\
\hline Areia média (\%) & 48,4 & 42,6 & 0,9 & 39,2 & 46,4 & 40,8 & 40,7 \\
\hline Areia grossa (\%) & 2,6 & 2,2 & 0,0 & 2,3 & 2,6 & 2,5 & 2,2 \\
\hline LL (\%) & 25 & 31 & 239 & 33 & 29 & 32 & 32 \\
\hline LP (\%) & 14 & 16 & 81 & 17 & 17 & 17 & 18 \\
\hline IP (\%) & 11 & 14 & 158 & 16 & 12 & 15 & 14 \\
\hline $\begin{array}{l}\text { Massa } \\
\text { específica dos } \\
\text { grãos }\left(\mathrm{g} / \mathrm{cm}^{3}\right)\end{array}$ & 2,690 & 2,69 & $\begin{array}{c}2,850 \\
a \\
2,950\end{array}$ & 2,706 & $\begin{array}{c}2,446 \\
a \\
2,643\end{array}$ & 2,701 & 2,686 \\
\hline $\begin{array}{l}\text { Classificação } \\
\text { SUCS }\end{array}$ & SC & SC & $\mathrm{MH}$ & SC & SC & SC & SC \\
\hline
\end{tabular}

(1) Mistura realizada com solo da segunda coleta

(2) Mistura realizada com solo da primeira coleta

De acordo com os resultados obtidos da caracterização geotécnica do solo e das misturas, pode-se dizer, então, que lodo acrescentado ao solo nas misturas 3:1, 4:1 e 5:1 não provocou variações importantes nos limites de consistência, na granulometria e na massa específica dos grãos. Além disso, os valores de LL, IP e porcentagem de argila cumprem com a maioria dos requerimentos mínimos para uso como camada de impermeabilização de fundo apresentados na Tabela 2.15. Porém, o parâmetro mais importante que deve e ser cumprido é a condutividade hidráulica. 


\subsection{COMPACTAÇÃO DO SOLO E DAS MISTURAS}

\subsubsection{Compactação do solo}

Os parâmetros de compactação do solo foram determinados a partir das curvas de compactação apresentadas na Figura 4.10. Foram realizados três ensaios de compactação com teores de umidade inicial distintos, visando estudar o efeito da secagem prévia das amostras nos parâmetros de compactação: dois ensaios com o solo seco até a umidade higroscópica e um com o solo seco até a umidade de 8,6\%.

É conhecido o fato de que o comportamento de alguns solos muda com a perda de água (Terzaghi et al., 1996). Solos lateríticos, particularmente, tendem a apresentar o efeito da secagem nos parâmetros de compactação (BERNUCCI, 1995), mas os efeitos da secagem no caso do solo em estudo não foram tão importantes, como mostrado na Figura 4.10, provavelmente por se tratar de um solo predominantemente arenoso.

Comparando-se as curvas de compactação do solo seco até $8,6 \%$ e até a umidade higroscópica (duas curvas, 1,0\% e 0,9\%), observa-se que a secagem prévia do solo não afetou o valor dos parâmetros de compactação e as diferenças estão dentro da variação experimental. A umidade ótima determinada foi de $12,4 \%$ e a massa específica seca máxima, de $1,910 \mathrm{~g} / \mathrm{cm}^{3}$. Esses valores são típicos de areias argilosas lateríticas, que podem apresentar valores de teor de umidade ótimo entre 12 e 14\% e massa específica seca máxima de $1,90 \mathrm{~g} / \mathrm{cm}^{3}$ (Pinto, 2006). 
Figura 4.10 - Curvas de compactação do solo.

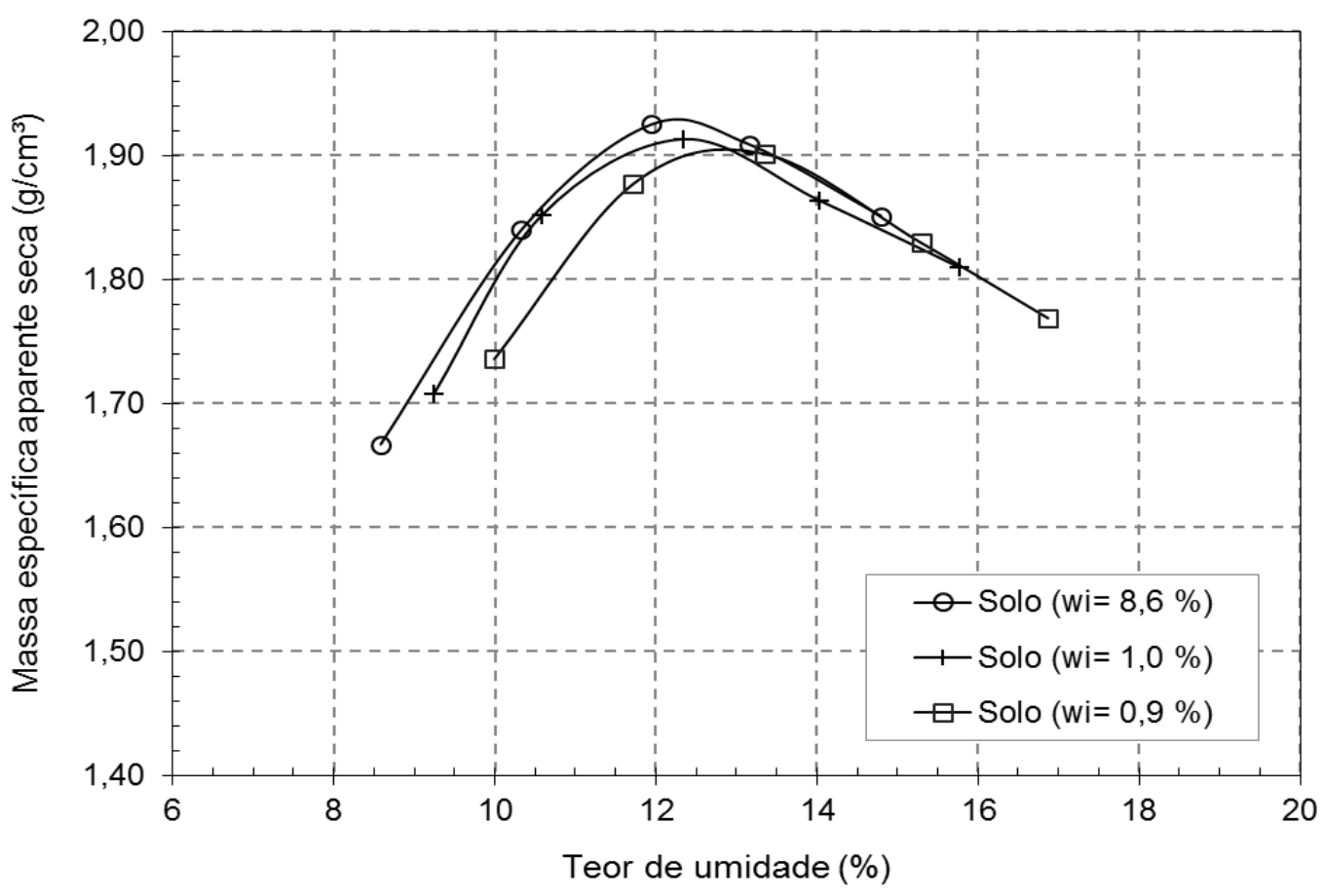

\subsubsection{Compactação das misturas}

Para as misturas de solo-lodo foram realizados ensaios de compactação com diferentes teores de umidade inicial $\left(\mathrm{W}_{\mathrm{i}}\right)$, visando estudar o efeito da secagem prévia das misturas nos parâmetros de compactação. Nas Figuras 4.11 a 4.13 são mostradas as curvas de compactação das misturas 3:1, 4:1 e 5:1, respectivamente. Os parâmetros de compactação do solo e das misturas para distintos valores de teor de umidade inicial são apresentados na Tabela 4.5.

Para as misturas 3:1 e 4:1 nas suas correspondentes umidades de mistura, ou seja, sem secagem prévia ao ensaio de compactação, não foi possível determinar os parâmetros de compactação, pois a umidade inicial já se encontrava acima da umidade ótima correspondente, como pode ser visto nas Figuras 4.11 e 4.12. Portanto, para essas misturas só foi possível determinar os parâmetros de compactação nos ensaios com secagem prévia a partir da umidade de mistura. Para a mistura 5:1, no entanto, a umidade da mistura estava no ramo seco da curva de compactação correspondente e foi adotada como a umidade inicial, ou seja, como o primeiro ponto do ensaio de compactação sem secagem prévia. 
Figura 4.11 - Curvas de compactação da mistura 3:1.

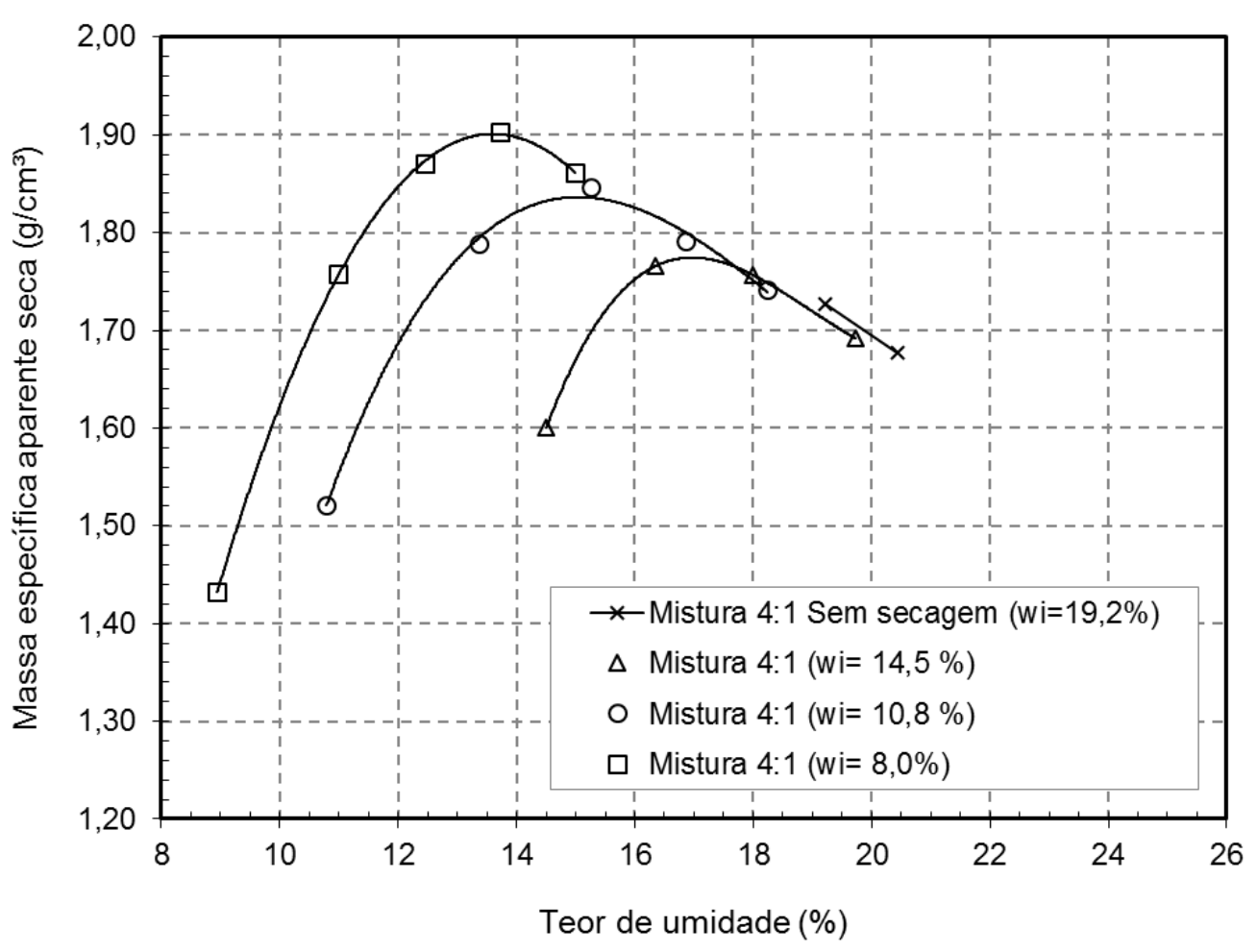

Figura 4.13 - Curvas de compactação da mistura 5:1.

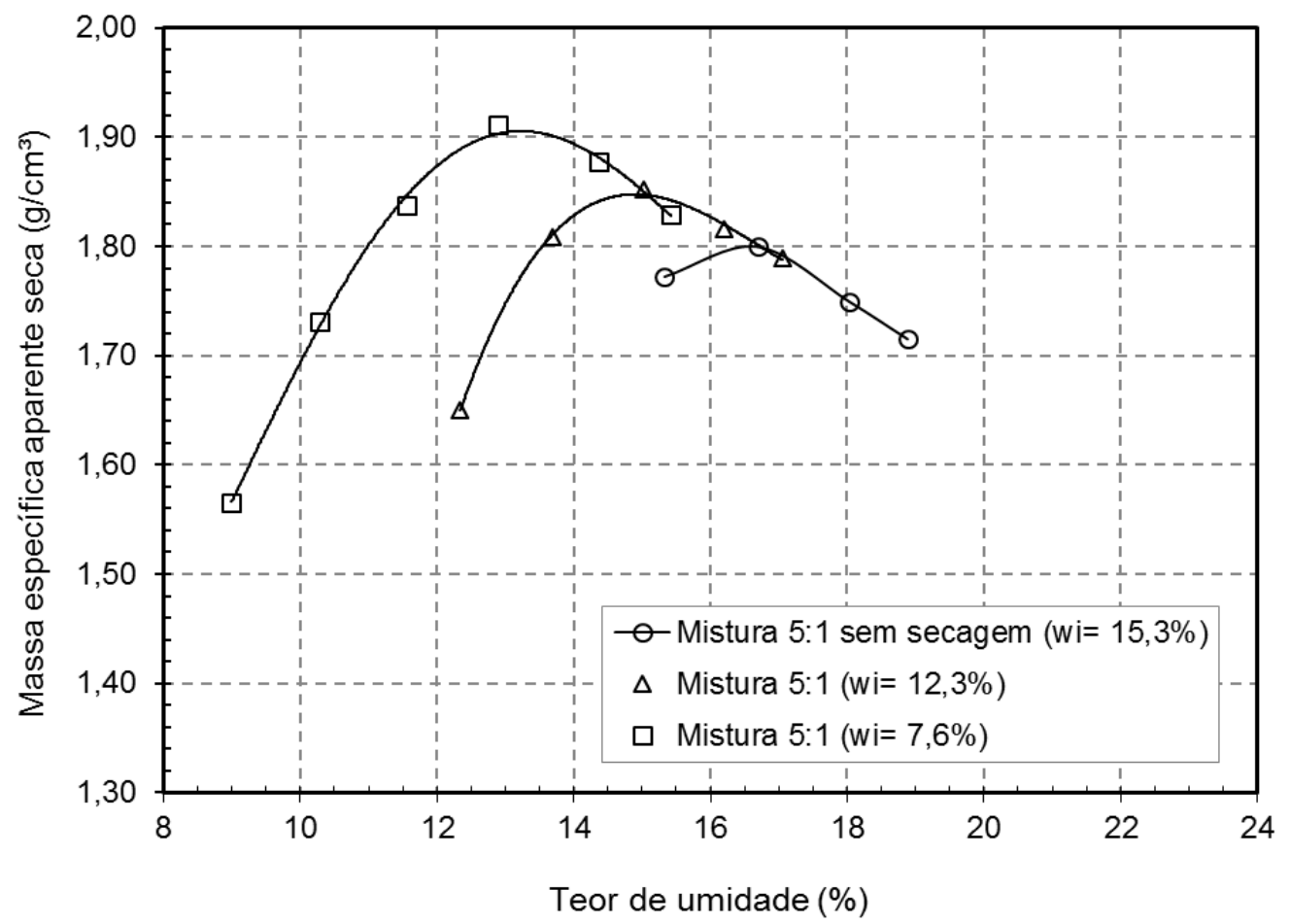


Tabela 4.5 - Parâmetros de compactação do solo e das misturas para distintos valores de teor de umidade inicial $\left(w_{i}\right)$ no ensaio de compactação.

\begin{tabular}{cccc}
\hline Material & $\mathbf{W}_{\mathbf{i}}(\%)$ & $\mathbf{w}_{\text {ot }}(\%)$ & $\gamma_{\mathbf{d} \text { máx }}\left(\mathbf{g} / \mathbf{c m}^{\mathbf{3}}\right)$ \\
\hline \multirow{3}{*}{ Solo laterítico } & 0,9 & 13,2 & 1,901 \\
& 1,0 & 12,4 & 1,905 \\
& 8,6 & 12,2 & 1,920 \\
\hline \multirow{2}{*}{ Mistura 3:1 (1) } & 13,5 & 16,1 & 1,810 \\
& 16,9 & 17,7 & 1,760 \\
\hline \multirow{2}{*}{ Mistura 4:1 (2) } & 9,7 & 14,6 & 1,845 \\
& 8,0 & 13,5 & 1,905 \\
& 10,8 & 15,0 & 1,850 \\
Mistura 5:1 ${ }^{(1)}$ & 14,5 & 17,0 & 1,780 \\
& 15,3 & 16,3 & 1,800 \\
& 12,3 & 14,9 & 1,850 \\
\hline
\end{tabular}

(1) Mistura realizada com o solo da segunda coleta

(2) Mistura realizada com o solo da primeira coleta

Para cada mistura, observa-se que quanto menor a umidade inicial (mais secagem), menor é o teor de umidade ótima e maior a massa específica seca máxima, ou seja, a curva de compactação se desloca para a esquerda e para cima. A secagem da mistura, portanto, tende a gerar um material com comportamento mais granular, pois curvas de compactação de solos granulares apresentam maior massa específica seca máxima e menor teor de umidade ótimo do que as de solos argilosos.

A variação dos parâmetros de compactação da mistura com a secagem pode ser explicada pelo comportamento do lodo quando submetido à perda de água. $\mathrm{O}$ lodo seco apresenta-se como um material granular: à medida que perde água, as partículas sofrem aglutinação formando partículas maiores fortemente cimentadas. $\mathrm{Na}$ mistura solo-lodo é possível que tenha ocorrido o mesmo; quanto maior a secagem, maiores as partículas formadas por aglutinação.

Com base nos parâmetros de compactação das misturas obtidos para distintos valores de teor de umidade inicial (Tabela 4.5), foi possível estabelecer relação linear entre o teor de umidade ótimo e o teor de umidade inicial do ensaio de compactação, mostrada na Figura 4.14, assim como relação linear entre a massa específica seca máxima e o teor de umidade inicial do ensaio de compactação, como mostrado na 
Figura 4.15. Consequentemente, também é possível estabelecer uma relação linear entre a massa específica seca máxima e o teor de umidade ótimo, na qual cada ponto representa um teor de umidade inicial no ensaio de compactação (Figura 4.16).

É interessante observar que a adição de lodo in natura ao solo resulta na diminuição da massa específica seca máxima e no aumento do teor de umidade ótimo. Por outro lado, a secagem da mistura solo-lodo permite que os parâmetros de compactação possam ser melhorados, tanto mais quanto maior a secagem.

As misturas 4:1 e 5:1 apresentaram na umidade de mistura massa específica seca de, respectivamente, 1,73 e $1,77 \mathrm{~g} / \mathrm{cm}^{3}$, porém as mesmas misturas podem apresentar massa específica seca máxima de $1,90 \mathrm{~g} / \mathrm{cm}^{3}$, valor muito próximo daquele correspondente ao solo, quando submetidas a secagem prévia até umidade inicial de 8,0\% para a mistura 4:1 e 7,6\% para a mistura 5:1, e depois ao acréscimo de umidade até a umidade ótima correspondente àquele nível de secagem (Figuras 4.12 e 4.13$)$.

Finalmente, comparando os parâmetros de compactação do solo e das misturas Tabela $4.5 \mathrm{com}$ aqueles dos solos residuais utilizados em diversas barragens apresentados na Tabela 2.16, vemos que os valores são muito parecidos, o que poderia significar que as misturas solo-lodo podem se apresentar adequadas como material de construção em barragens.

\section{Figura 4.14 - Variação do teor de umidade ótimo com a} umidade inicial no ensaio de compactação das misturas.

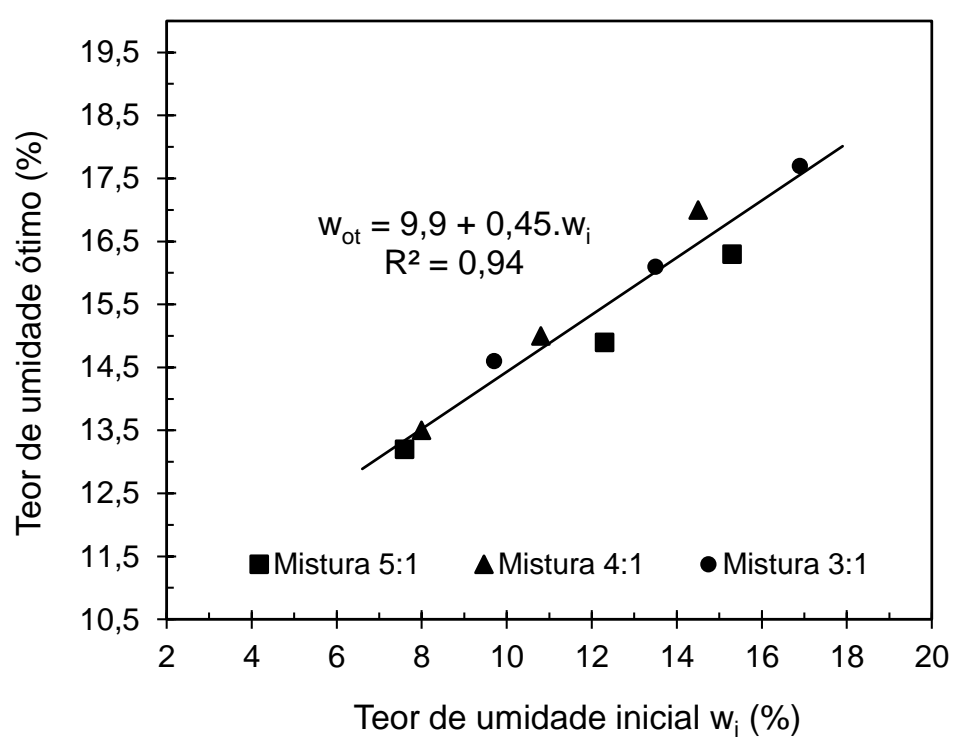


Figura 4.15 - Variação da massa específica seca máxima com a umidade inicial no ensaio de compactação das misturas.

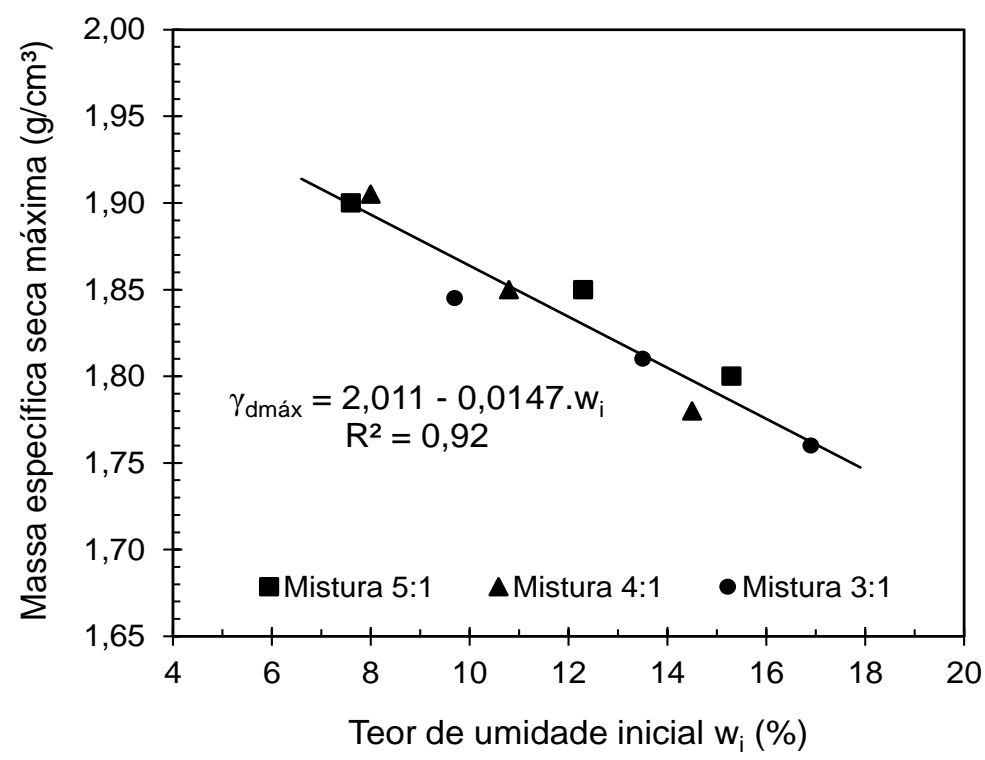

Figura 4.16 - Variação da massa específica seca máxima com o teor de umidade ótimo das misturas.

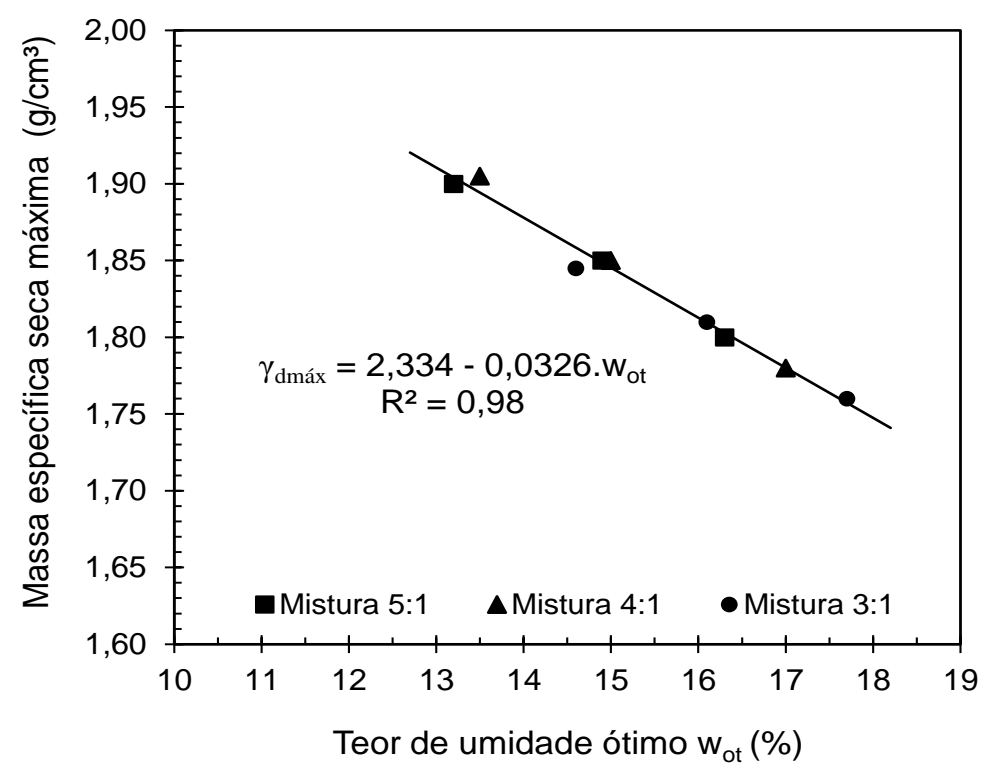




\subsubsection{Compactação e moldagem de corpos de prova}

$\mathrm{Na}$ Tabela 4.6 são apresentadas as características dos corpos de prova de solo e das misturas 3:1, 4:1 e 5:1, compactados com energia Proctor normal. O solo foi compactado no teor de umidade ótimo e as misturas na umidade de mistura (ver Tabela 4.5). Esses espécimes foram utilizados para moldar os corpos de prova a serem utilizados nos ensaios de deformabilidade, permeabilidade e resistência.

Tabela 4.6 - Características dos corpos de prova compactados do solo e das misturas.

\begin{tabular}{lcccc}
\hline Material & Solo & Mistura 3:1 & Mistura 4:1 & Mistura 5:1 \\
\hline$\%$ Lodo (massa úmida) & - & $25,0 \%$ & $20,0 \%$ & $16,7 \%$ \\
$\%$ Lodo (massa seca) & - & $7,6 \%$ & $5,7 \%$ & $4,5 \%$ \\
w (\%) & 12,8 & 24,5 & 19,2 & 15,3 \\
$\gamma_{\mathrm{d}}\left(\mathrm{g} / \mathrm{cm}^{3}\right)$ & 1,86 & 1,57 & 1,73 & 1,76 \\
$\mathrm{e}_{0}$ & 0,45 & 0,72 & 0,56 & 0,53 \\
\hline
\end{tabular}

\subsection{DEFORMABILIDADE DO SOLO E DAS MISTURAS}

O estudo da deformabilidade do solo e das misturas solo-lodo foi realizado por ensaios de adensamento unidimensional em corpos de prova compactados. $\mathrm{Na}$ Tabela 4.6 são apresentadas as características dos corpos de prova compactados. As curvas de adensamento (Índice de vazios vs. tensão vertical efetiva) do solo e das misturas obtidas nos ensaios de adensamento são apresentadas na Figura 4.17 e os índices compressão e recompressão determinados são apresentados na Tabela 4.7.

O solo compactado na umidade de $12,8 \%$ (desvio de $0,4 \%$ da ótima) e massa específica seca de $1,86 \mathrm{~g} / \mathrm{cm}^{3}$ (grau de compactação $\mathrm{GC}=97,5 \%$ ) apresentou um índice de compressão $\left(\mathrm{C}_{c}\right)$ de 0,07 e um índice de recompressão $\left(\mathrm{C}_{\mathrm{r}}\right)$ de 0,02 . As misturas 3:1, 4:1 e 5:1 compactadas na umidade de mistura, ou seja, sem secagem prévia (ver Figuras 4.11 a Figura 4.13), apresentaram valores de $C_{c}$ de 0,19, 0,13 e 0,14 , respectivamente, valores maiores do que aquele do solo, o que indica que as misturas são mais compressíveis do que o solo compactado no teor de umidade ótimo. Os valores de $\mathrm{C}_{\mathrm{r}}$ obtidos para as misturas 3:1, 4:1 e 5:1 foram respectivamente 0,02, 0,02 e 0,03, praticamente o mesmo valor de $\mathrm{Cr}_{\mathrm{r}}$ obtido para o solo. 
Figura 4.17 - Curvas de adensamento do solo e das misturas solo-lodo.

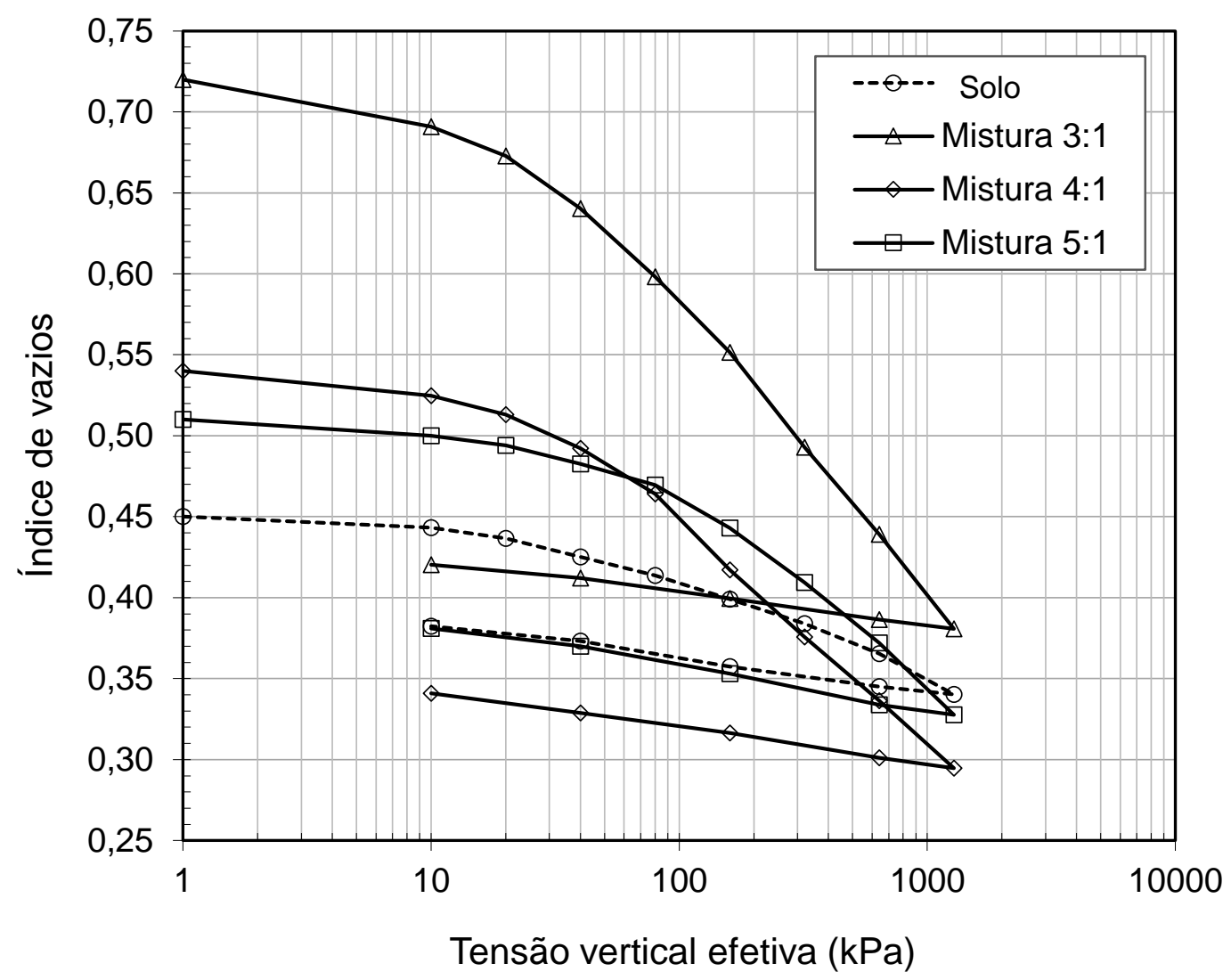

Tabela 4.7 - Índices de compressão e recompressão do solo e das misturas determinados no ensaio de adensamento.

\begin{tabular}{lcccc}
\hline Material & Solo & Mistura 3:1 & Mistura 4:1 & Mistura 5:1 \\
\hline $\mathrm{C}_{\mathrm{c}}$ & 0,07 & 0,19 & 0,13 & 0,14 \\
$\mathrm{C}_{\mathrm{r}}$ & 0,02 & 0,02 & 0,02 & 0,03 \\
\hline
\end{tabular}

Wang, Hull e Jao (1992) realizaram ensaios de adensamento com uma mistura de solo-lodo na proporção 37,5\% / 62,5\% em massa seca. O solo utilizado na mistura solo-lodo foi uma areia argilosa classificada como SC. Determinou-se $\mathrm{C}_{\mathrm{c}}$ da mistura igual a 4,04, representativo de solos altamente compressíveis. Valores de Cc nessa magnitude têm sido obtidos para lodos in natura, variando entre 1,99 e 6,69 (O'KELLY, 2008; WANG et al., 1992).

Os valores de $\mathrm{C}_{\mathrm{c}}$ determinados para as misturas nesta pesquisa foram muito inferiores aos valores reportados na bibliografia por Wang, Hull e Jao (1992). Porém, 
nesta pesquisa foram utilizadas porcentagens muito mais baixas de lodo em massa seca, 6,6\% na mistura $3: 1,5,7 \%$ na mistura $4: 1$, e 4,5\% na mistura 5:1. Diante do exposto, pode-se concluir que em misturas solo-lodo com porcentagem baixa de lodo em massa seca, prevalecem as propriedades do solo, mas em misturas com porcentagem de lodo elevada, prevalecem as propriedades do lodo sempre.

\subsection{PERMEABILIDADE}

\subsubsection{Permeabilidade em célula de adensamento}

Foram realizados ensaios de permeabilidade com permeâmetro de carga variável na célula de adensamento em diferentes tensões verticais efetivas: 40, 320, 640 e 1280 kPa. Para cada nível de tensão corresponde um índice de vazios, o qual diminui à medida que o nível de tensão aumenta.

Na Figura 4.18 são mostrados os resultados dos ensaios de permeabilidade do solo e das misturas. Os resultados com o solo apresentaram uma tendência incomum, aumento do coeficiente de condutividade hidráulica $(k)$ com a diminuição do índice de vazios $(e)$, tendendo no final a um valor constante $\left(1,6 \times 10^{-6} \mathrm{~m} / \mathrm{s}\right)$. Para as misturas, observou-se também um comportamento inesperado: a permeabilidade praticamente não variou com a diminuição do índice de vazios. O coeficiente de condutividade hidráulica, no entanto, deveria diminuir com a redução do índice de vazios, pois com o decréscimo do tamanho dos poros há maior dificuldade na percolação da água.

Uma possível explicação para o comportamento observado pode ser a não saturação inicial dos corpos de prova de solo e da mistura e o aumento da saturação à medida que aumentava o nível de tensão. A permeabilidade aumenta com o grau de saturação, sendo máxima quando o solo está saturado, como demonstrado amplamente na bibliografia. Como exemplo, os ensaios realizados por Bicalho, Znidarcic e Ko (2005) em um solo compactado com graus de saturação entre 80 e $100 \%$, classificado como silte de baixa plasticidade, mostraram que, quanto maior a saturação, maior a permeabilidade.

Assim, estariam se sobrepondo dois efeitos opostos no valor do coeficiente de permeabilidade, o da diminuição do índice de vazios e o do aumento da saturação. 
Figura 4.18 - Variação do coeficiente de condutividade

hidráulica do solo e das misturas na célula de adensamento.

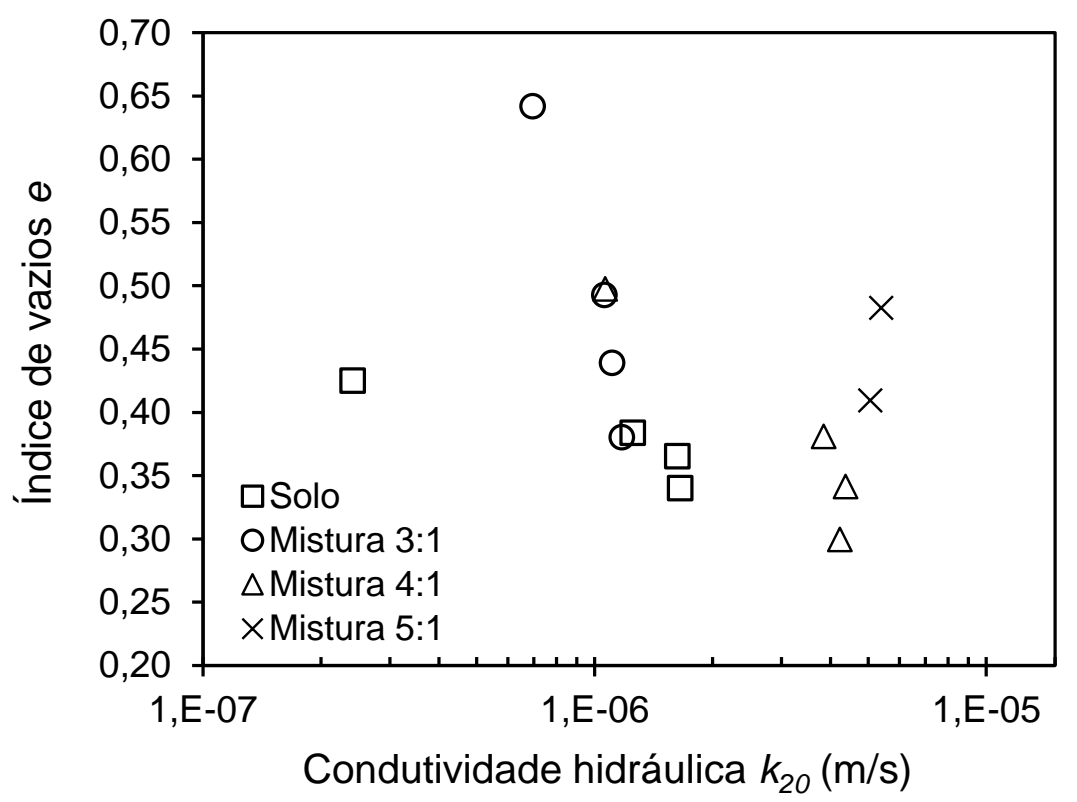

O valor praticamente constante do coeficiente de condutividade hidráulica das misturas foi de $1,1 \times 10^{-6} \mathrm{~m} / \mathrm{s}$ para a mistura $3: 1,4,3 \times 10^{-6} \mathrm{~m} / \mathrm{s}$ para a mistura $4: 1 \mathrm{e}$ $5,0 \times 10^{-6} \mathrm{~m} / \mathrm{s}$ para a mistura 5:1. Esperava-se que o coeficiente de condutividade hidráulica diminuísse da mistura 3:1 para a mistura 5:1, considerando-se o índice de vazios inicial de cada corpo de prova (ver Figura 4.17).

Deve-se lembrar, porém, que o desvio de umidade de compactação dos aumentou com a quantidade de lodo na mistura. Por um lado, quanto maior a proporção de lodo, maior a umidade de mistura $(24,5 \%, 19,2 \%$ e $15,3 \%$ respectivamente para as misturas 3:1, 4:1 e 5:1). Por outro lado, com o teor de umidade ótimo calculado pela correlação obtida na Figura 4.14, os desvios de umidade para as misturas $3: 1,4: 1$ e $5: 1$ foram de $+3,6 \%,+0,7 \%$ e $-1,5 \%$ respectivamente. Solos compactados acima da umidade ótima apresentam estrutura mais dispersa, o que corresponde a uma permeabilidade mais baixa (LAMBE; WHITMAN, 1969).

\subsubsection{Permeabilidade do solo em permeâmetro de parede flexível}

Os resultados do ensaio de permeabilidade do solo em permeâmetro de parede flexível são mostrados na Figura 4.19. Os coeficientes de condutividade hidráulica são referidos à temperatura de $20^{\circ} \mathrm{C}\left(\mathrm{k}_{20}\right)$. 
O solo ensaiado sob pressão confinante $\left(\sigma_{c}\right)$ de $30 \mathrm{kPa}$ apresentou valores do coeficiente de condutividade hidráulica de $1,3 \times 10^{-6} \mathrm{~m} / \mathrm{s}$ para gradiente hidráulico (i) de 5 , e $6,8 \times 10^{-6}$ para gradiente de 10 . Sob pressão confinante de $60 \mathrm{kPa}$, obtiveramse coeficientes de condutividade hidráulica de $4,3 \times 10^{-7} \mathrm{~m} / \mathrm{s}$ para gradiente de 5 e $3,9 \times 10^{-7} \mathrm{~m} / \mathrm{s}$ para gradiente de 10 .

No início do ensaio realizado com pressão confinante de $30 \mathrm{kPa}$ e gradiente de 5 , a condutividade hidráulica aumentou com a percolação d'água até a passagem de 5 volumes de vazios $(\mathrm{Vv})$, a partir do que se apresentou constante, provavelmente porque foi atingida constância do grau de saturação. Por outro lado, com o aumento do gradiente hidráulico de 5 para 10, aumentou a condutividade hidráulica, esse comportamento pode ser devido à formação de caminhos preferencias de percolação entre a membrana e corpo de prova dada a baixa pressão confinante $(30 \mathrm{kPa})$ e o aumento da pressão neutra induzido pelo incremento do gradiente.

Figura 4.19 - Coeficiente de condutividade hidráulica do solo para distintos valores de pressão confinante e gradiente hidráulico.

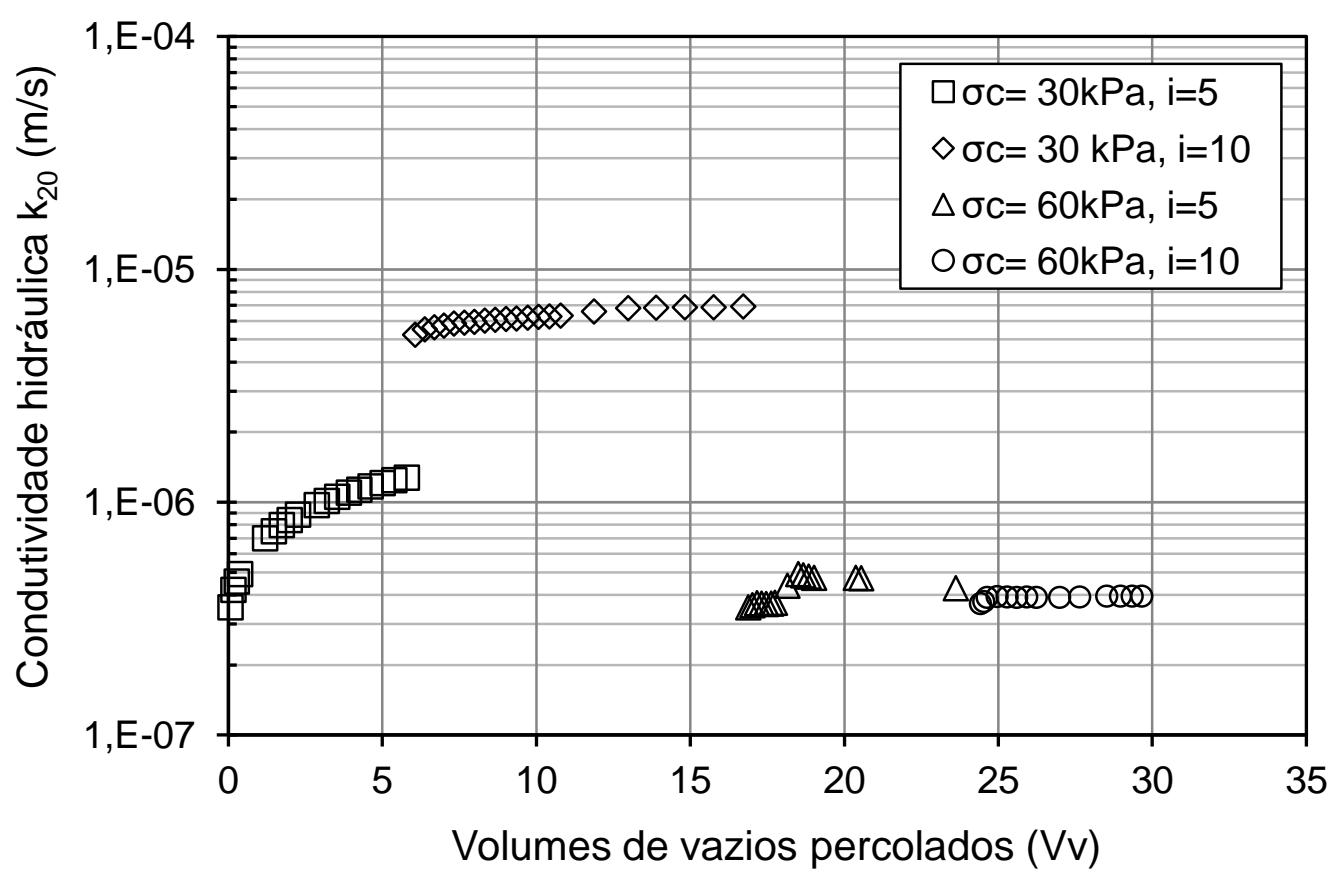

Com o aumento da tensão confinante de 30 para $60 \mathrm{kPa}$ a condutividade hidráulica diminuiu, mas se manteve praticamente constante para os gradientes de 5 e 10, que era o esperado. 


\subsubsection{Permeabilidade das misturas em permeâmetro de parede flexível}

Os resultados dos ensaios de permeabilidade das misturas em permeâmetro de parede flexível são mostrados nas Figuras 4.20 a 4.22, e na Tabela 4.8 são apresentados os coeficientes de condutividade hidráulica para o solo e as misturas, determinados a partir dos gráficos nessas figuras.

A mistura 5:1 ensaiada sob pressão confinante de $30 \mathrm{kPa}$ apresentou coeficiente de condutividade hidráulica de $1,4 \times 10^{-6} \mathrm{~m} / \mathrm{s}$ para gradiente hidráulico de 5

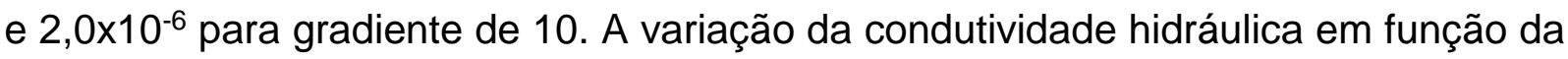
duplicação do gradiente não foi significativa, que era o esperado, enquanto para o solo ocorreu um aumento de 5 vezes. Sob pressão confinante de $60 \mathrm{kPa}$, obteve-se coeficiente de condutividade hidráulica de $1,6 \times 10^{-7} \mathrm{~m} / \mathrm{s}$ para os gradientes de 5 e 10, comportamento similar ao do solo. Todos esses valores são maiores que o valor mínimo normalmente estabelecido como requerimento para camada de impermeabilização de fundo em aterros sanitários $\left(1 \times 10^{-9} \mathrm{~m} / \mathrm{s}\right)$, o que impossibilita o uso da mistura 5:1 nesse tipo de aplicação específicamente.

Figura 4.20 - Coeficiente de condutividade hidráulica da mistura 5:1 para distintos valores de pressão confinante e gradiente hidráulico.

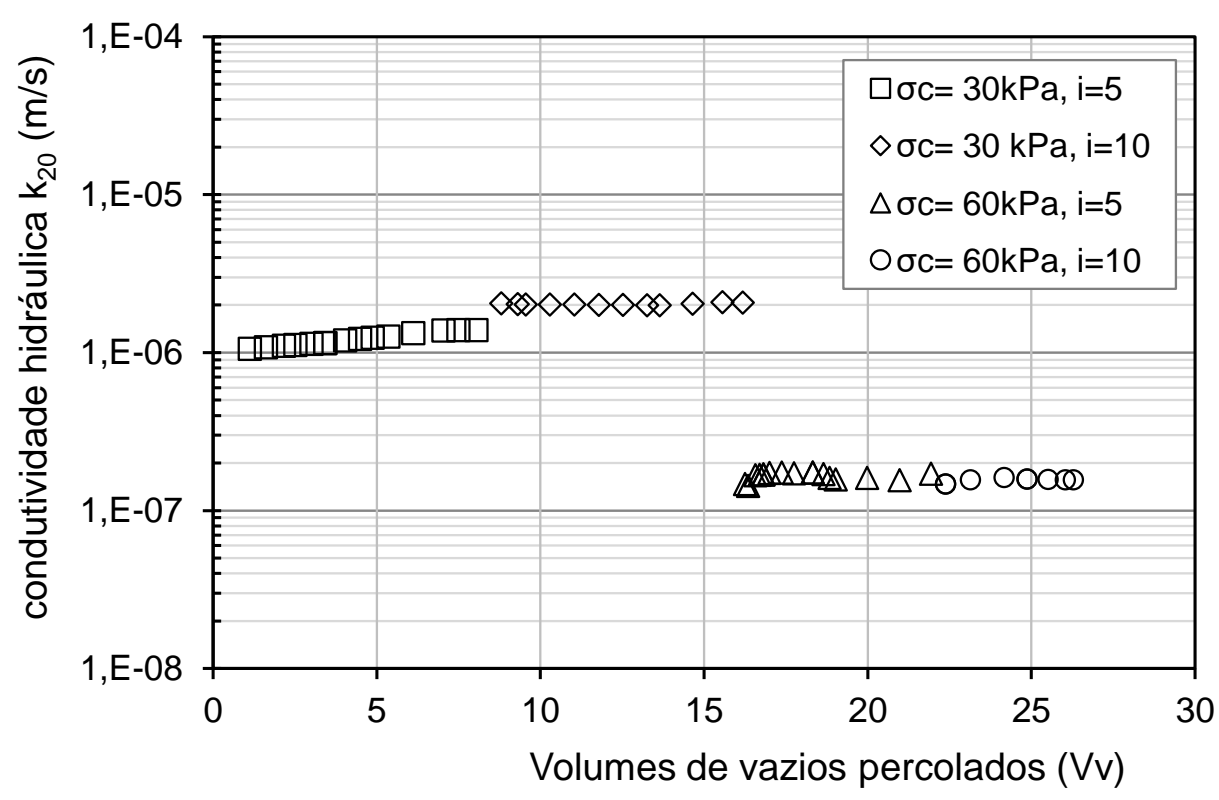


Figura 4.22 - Coeficiente de condutividade hidráulica da mistura 4:1 para distintos valores de pressão confinante e gradiente hidráulico.

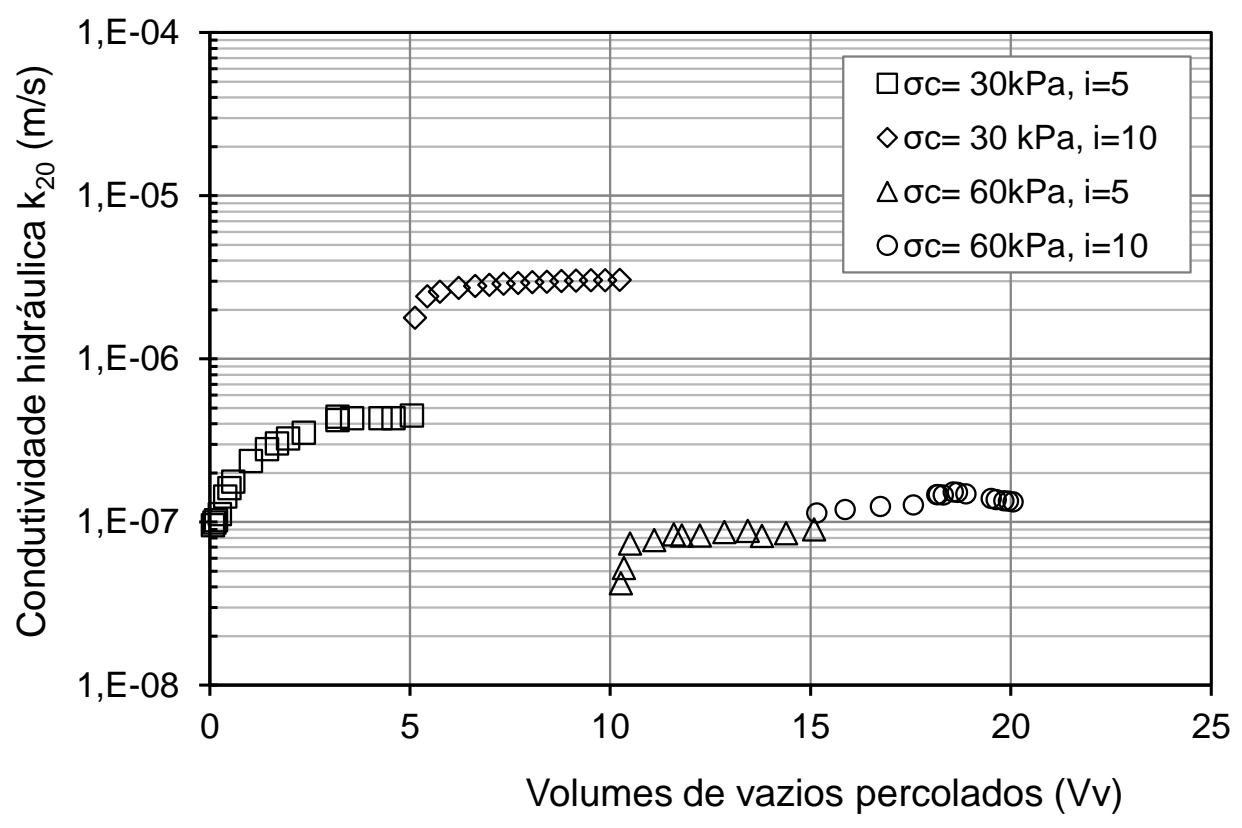

Figura 4.21 - Coeficiente de condutividade hidráulica da mistura 3:1 para pressão confinante de $30 \mathrm{kPa}$ e distintos valores de gradiente.

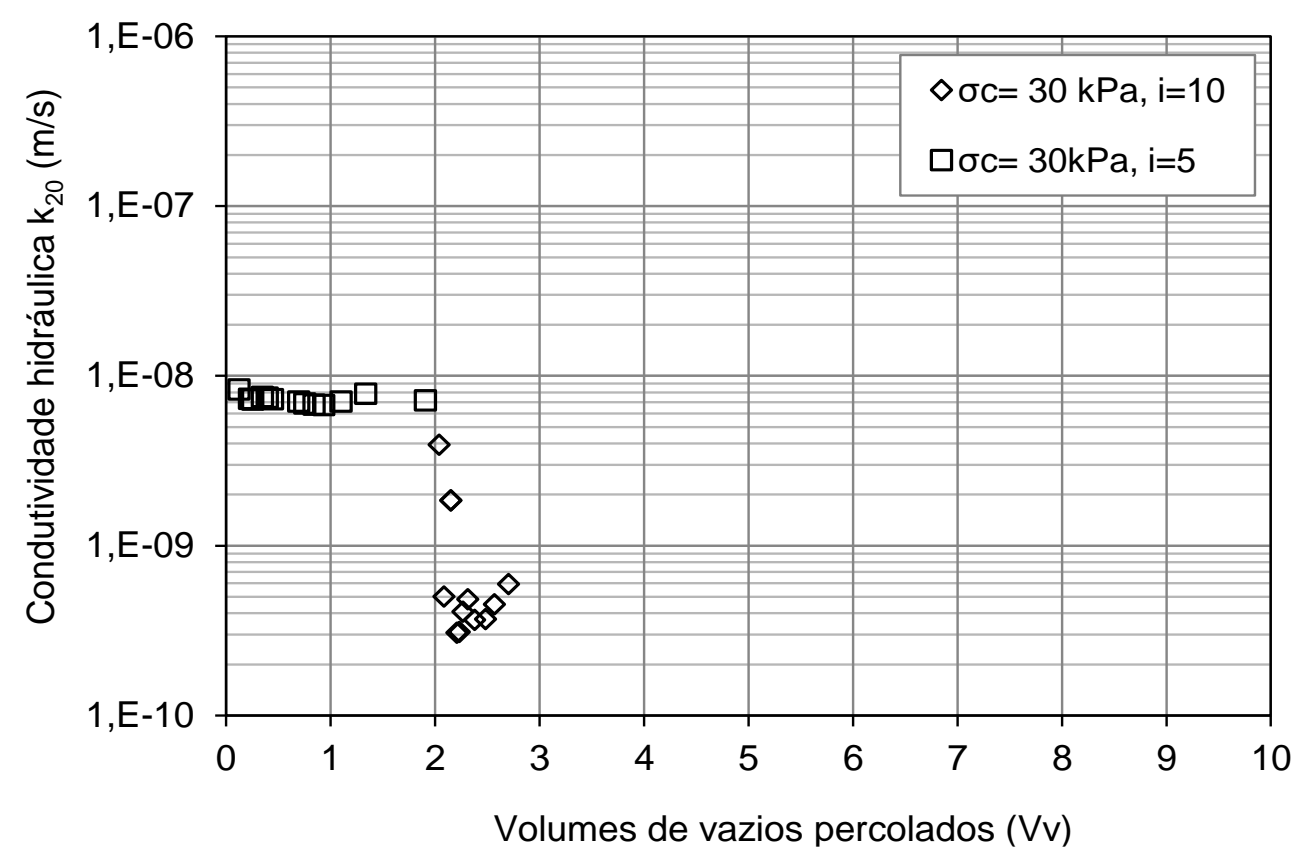

A mistura 4:1 ensaiada sob pressão confinante de $30 \mathrm{kPa}$ apresentou coeficiente de condutividade hidráulica de $4,3 \times 10^{-7} \mathrm{~m} / \mathrm{s}$ para gradiente hidráulico de 5 e $3,0 \times 10^{-6}$ para gradiente de 10 , um aumento de 6 vezes, semelhante ao ocorrido 
para o solo. Para pressão confinante de $60 \mathrm{kPa}$, foram obtidos coeficientes de condutividade hidráulica de $8,7 \times 10^{-8} \mathrm{~m} / \mathrm{s}$ para gradiente de 5 e $1,3 \times 10^{-7} \mathrm{~m} / \mathrm{s}$ para gradiente de 10, valores bastante próximos (ver Figura 4.22). Esses valores não são adequados para uso em revestimento de fundo em aterros sanitários.

A mistura 3:1 apresentou coeficiente de condutividade hidráulica de $7,0 \times 10^{-9} \mathrm{~m} / \mathrm{s}$ (valor adequado para uso em revestimento de fundo em aterros sanitários) quando ensaiada com pressão confinante de $30 \mathrm{kPa}$ e gradiente hidráulico de 5 , determinado com base em leituras durante 17 dias e percolação de um volume de água de 2 volumes de vazios do corpo de prova. Ao aumentar o gradiente de 5 até 10, a condutividade hidráulica começou a diminuir. Após 47 dias de leituras o volume percolado era de apenas 0,7 volumes de vazios. Decidiu-se interromper o ensaio, pois suspeitou-se que o papel filtro entre a amostra e a pedra porosa tivesse colmatado. Realmente, após desmontar o corpo de prova verificou-se a colmatação do papel filtro e a amostra havia-se tornado preta, indicando a ocorrência de alguma reação química do lodo presente na mistura (ver Figura 4.23).

Tabela 4.8 - Coeficientes de condutividade hidráulica ( $\left(k_{20} \mathrm{em} \mathrm{m} / \mathrm{s}\right)$ do solo e das misturas para distintos valores de pressão confinante e gradiente hidráulico.

\begin{tabular}{cccccc}
\hline Pressão confinante $(\mathbf{k P a})$ & $\mathbf{i}$ & Solo & Mistura 5:1 & Mistura 4:1 & Mistura 3:1 \\
\hline \multirow{2}{*}{30} & 5 & $1,3 \times 10^{-06}$ & $1,4 \times 10^{-06}$ & $4,3 \times 10^{-07}$ & $7,0 \times 10^{-09}$ \\
& 10 & $6,9 \times 10^{-06}$ & $2,0 \times 10^{-06}$ & $3,0 \times 10^{-06}$ & - \\
\multirow{2}{*}{60} & 5 & $4,3 \times 10^{-07}$ & $1,6 \times 10^{-07}$ & $8,7 \times 10^{-08}$ & - \\
& 10 & $3,9 \times 10^{-07}$ & $1,6 \times 10^{-07}$ & $1,3 \times 10^{-07}$ & - \\
\hline
\end{tabular}

Pode-se dizer que a condutividade hidráulica do solo compactado varia entre $4 \times 10^{-7}$ e $7 \times 10^{-6} \mathrm{~m} / \mathrm{s}$ para tensões confinantes entre 30 e $60 \mathrm{kPa}$ e gradientes hidráulicos entre 5 e 10. O acréscimo de lodo ao solo tende a diminuir a condutividade hidráulica por introduzir mais finos, porém isso não pode ser concluído com base nos resultados dos ensaios desta pesquisa, visto que as diferenças observadas podem estar dentro da variação experimental.

Observa-se que o aumento da tensão confinante de 30 para $60 \mathrm{kPa}$ diminui a condutividade hidráulica do solo e das misturas, porém em menos de uma ordem de 
grandeza. O aumento do gradiente hidráulico de 5 para 10 pode aumentar a condutividade hidráulica do solo e das misturas em até 6 vezes sob tensão confinante de $30 \mathrm{kPa}$ e não a altera sob tensão confinante de $60 \mathrm{kPa}$, isso talvez devido à formação de caminhos preferenciais de percolação entre a membrana e o corpo de prova sob baixa pressão confinante $(30 \mathrm{kPa})$.

Figura 4.23 - Corpo de prova da mistura 3:1 utilizado no ensaio de permeabilidade em permeâmetro parede flexível.

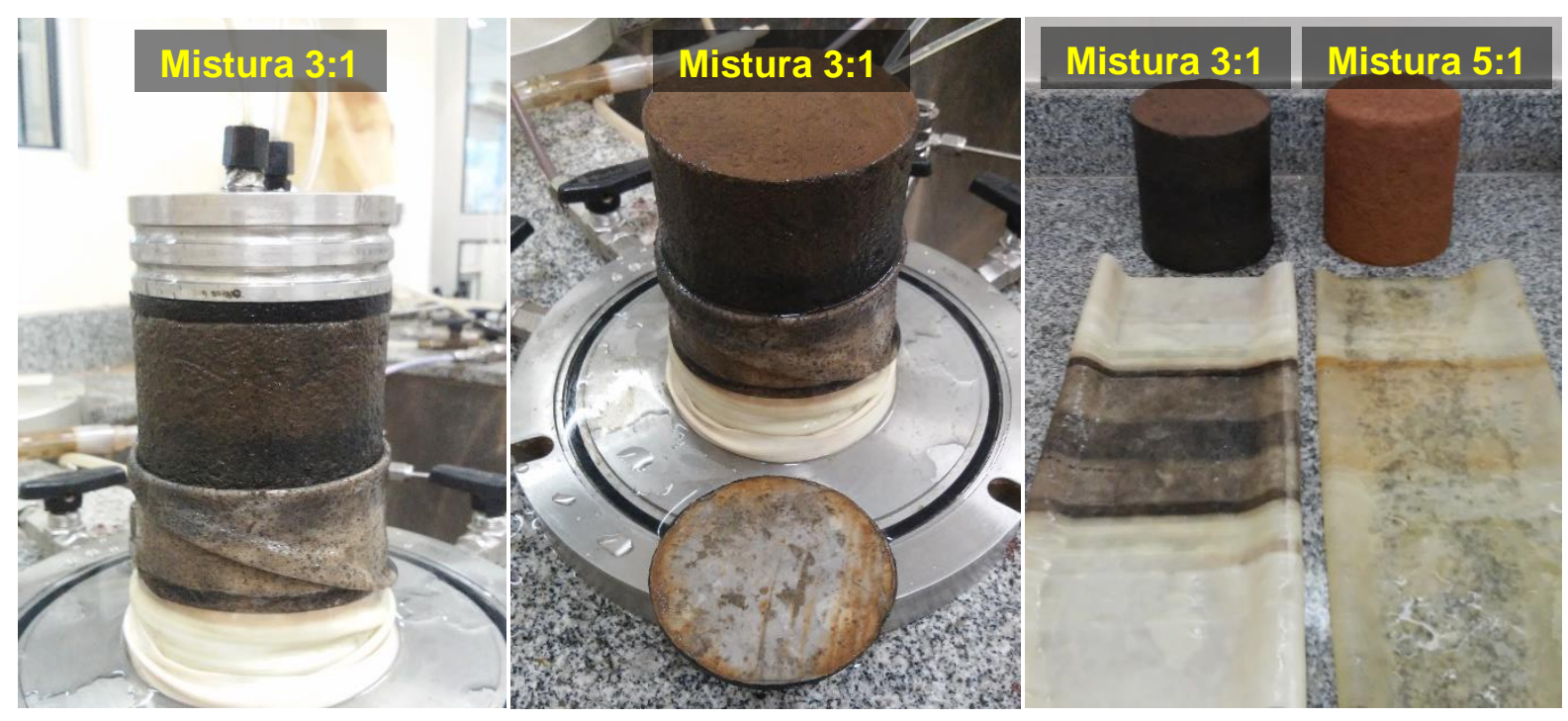

\subsection{RESISTÊNCIA AO CISALHAMENTO}

\subsubsection{Resistência ao cisalhamento do solo}

No ensaio de compressão triaxial adensado anisotropicamente não drenado (CAU) foram obtidas as curvas tensão-deformação e pressão neutra-deformação do solo para valores de tensão principal menor de adensamento $\left(\sigma_{3 c}\right)$ de 50, 100 e 200 $\mathrm{kPa}$, apresentadas na Figura 4.24. Dado que o adensamento foi anisotrópico com uma razão de tensões $\left(K=\sigma^{\prime}{ }_{3} / \sigma^{\prime}{ }_{1}\right)$ de 0,8 , os valores da tensão principal maior de adensamento $\left(\sigma_{1 \mathrm{c}}\right)$ foram de $62,5,125$, e $250 \mathrm{kPa}$ correspondentes aos valores de tensão principal menor de 50,100 e 200, respectivamente.

Pode-se observar na Figura 4.24 que o solo desenvolveu pressão neutra negativa nos ensaios realizados com tensão confinante' ${ }^{1}\left(\sigma_{3 c}\right)$ de 50 e $100 \mathrm{kPa}$, mas

\footnotetext{
${ }^{1}$ Doravante a tensão principal menor de adensamento será chamada apenas de tensão confinante.
} 
no ensaio com tensão confinante de $200 \mathrm{kPa}$ não houve desenvolvimento de pressão neutra negativa. $O$ desenvolvimento de pressão neutra positiva é devido à tendência de compressão volumétrica do solo durante o cisalhamento no ensaio de compressão triaxial adensado anisotropicamente não drenado (CAU). Por outro lado, o desenvolvimento de pressão neutra negativa é devido à tendência do solo a expandir-se durante o cisalhamento, comportamento típico de areias compactas e argilas muito sobreadensadas, assim como de solos compactados.

Figura 4.24 - Resultados do ensaio triaxial não drenado (CAU) no solo: curvas tensão-deformação e pressão neutra vs. deformação.
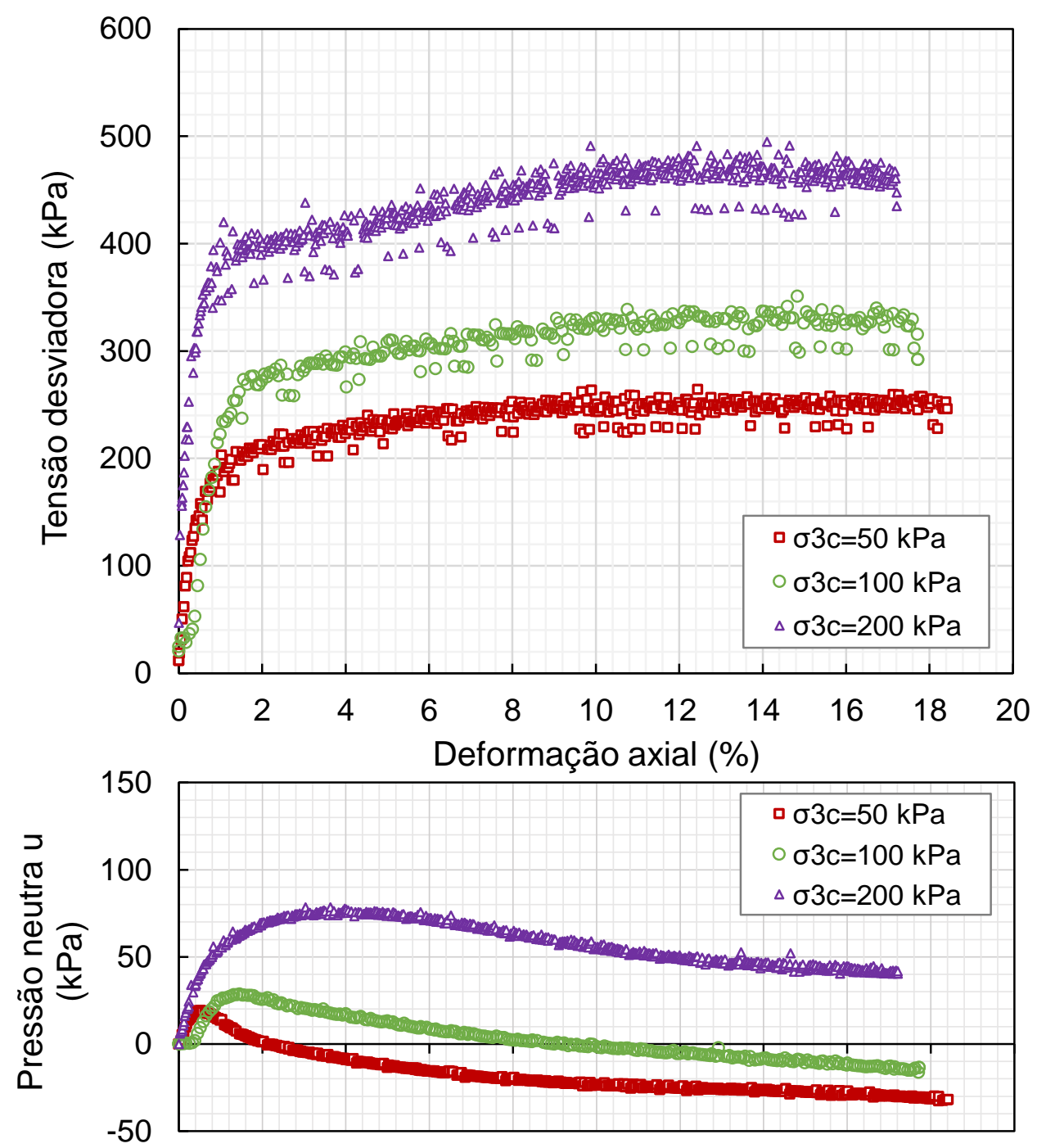

$\mathrm{Na}$ Figura 4.25 são apresentadas as trajetórias de tensões correspondentes aos ensaios realizados com tensão confinante de 50, 100 e $200 \mathrm{kPa}$. Na 
representação das trajetórias de tensões foi utilizado o diagrama tipo MIT (LAMBE; WHITMAN, 1969):

$$
\begin{aligned}
& \mathrm{q}=\frac{\sigma_{1}-\sigma_{3}}{2} \\
& \mathrm{p}^{\prime}=\frac{\sigma_{1}+\sigma_{3}}{2}
\end{aligned}
$$

Na trajetória de tensões é possível definir uma reta que define a envoltória de resistência com parâmetros $\beta$ e d, onde $\beta$ é o ângulo formado pela reta da envoltória e o eixo horizontal ( $\left.p^{\prime}\right)$, e d é o intercepto com o eixo vertical (q). Os parâmetros de resistência, ângulo de atrito efetivo $\left(\varphi^{\prime}\right)$ e coesão efetiva (c'), foram calculados a partir dos parâmetros $\beta$ e d pelas relações a seguir:

$$
\begin{aligned}
& \operatorname{sen}\left(\varphi^{\prime}\right)=\tan (\beta) \\
& \mathbf{c}^{\prime}=\frac{\mathrm{d}}{\operatorname{sen}(\beta)}
\end{aligned}
$$

Os valores determinados para o ângulo de atrito efetivo e a coesão efetiva do solo foram $34^{\circ}$ e $22 \mathrm{kPa}$, respectivamente.

Os parâmetros de resistência também foram determinados por meio do círculo de Mohr, utilizando as tensões efetivas principal menor e maior na ruptura. Os dois critérios de ruptura comumente utilizados são o máximo valor da tensão desviadora

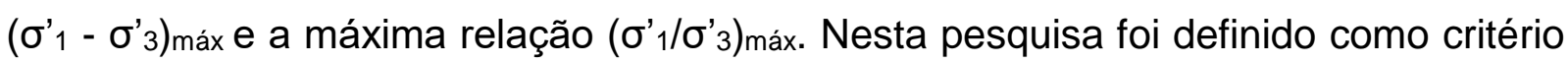
de ruptura a máxima relação $\sigma_{1}{ }_{1} / \sigma^{\prime}{ }_{3}$; a partir desse valor foram determinadas as tensões principais menor e maior e construído o círculo de Mohr para as tensões confinantes de 50, 100 e $200 \mathrm{kPa}$.

A Figura 4.26 mostra os círculos de Mohr e a reta tangente que define a envoltória de resistência com valores dos parâmetros de ângulo de atrito efetivo e coesão efetiva respectivamente de $34^{\circ}$ e $22 \mathrm{kPa}$, exatamente iguais aos determinados a partir da envoltória de resistência na trajetória de tensões. 
Figura 4.25 - Resultados do ensaio triaxial não drenado (CAU) no solo: Diagrama de trajetórias de tensões efetivas.

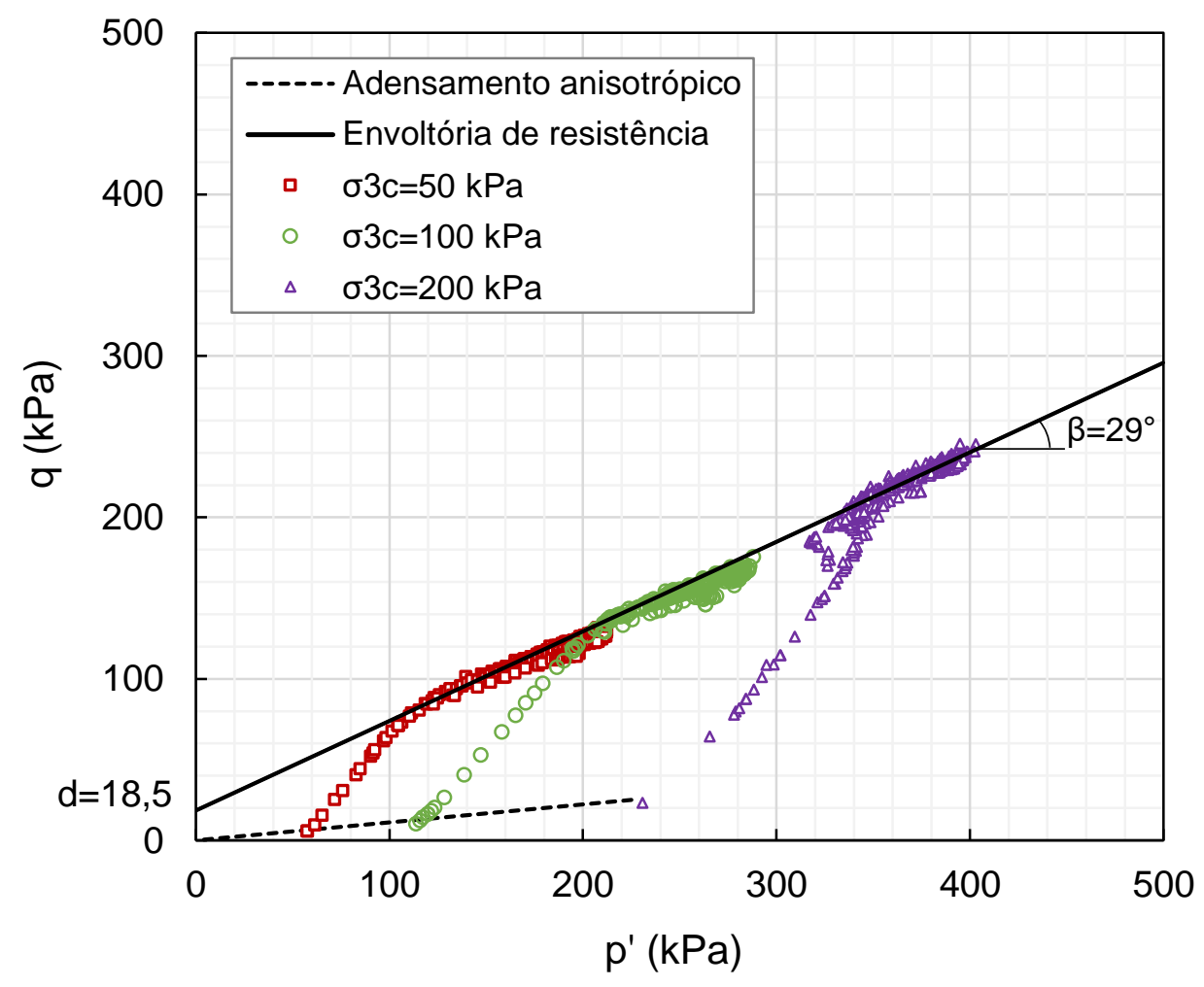

Figura 4.26 - Círculos de Mohr e envoltória de resistência em termos de tensões efetivas do solo.

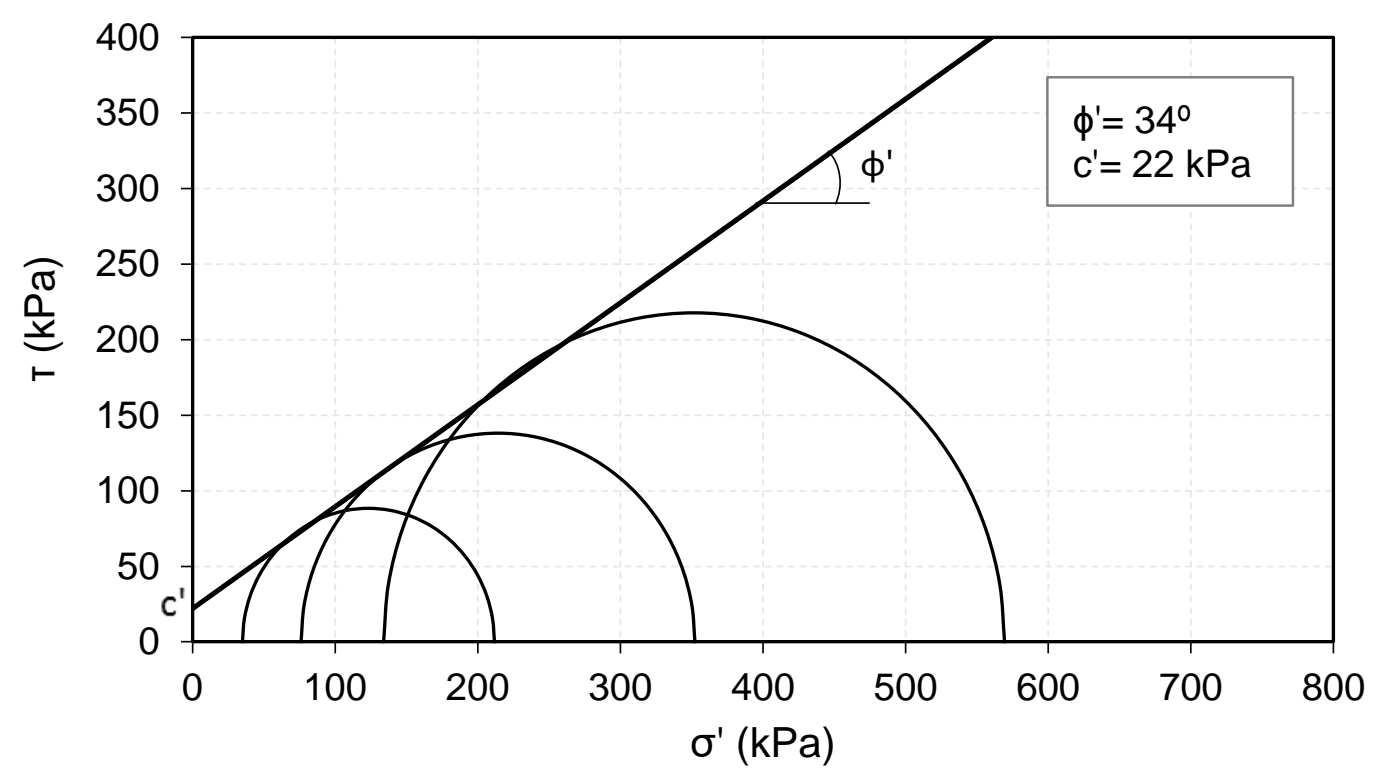




\subsubsection{Resistência ao cisalhamento das misturas}

Nas Figuras 4.27 a 4.29 são apresentadas as curvas tensão-deformação e pressão neutra-deformação das misturas, correspondentes aos valores de tensão principal menor de adensamento $\left(\sigma_{3 c}\right)$ de 50,100 e $200 \mathrm{kPa}$.

Ao comparar as curvas tensão-deformação das misturas com as do solo, pode-se observar que o solo apresentou maiores valores de tensão desviadora máxima, ou seja, maior resistência. Esse comportamento é devido ao fato do solo ter sido compactado numa massa específica seca maior do que as das misturas (ver Tabela 4.6).

A mistura 3:1 (Figura 4.27) apresentou os menores valores de tensão desviadora. Esse comportamento já era esperado, pois essa mistura foi compactada na menor massa específica seca e com o maior teor de umidade em relação às outras misturas.

As misturas 4:1 e 5:1 (Figura 4.28 e 4.29) apresentaram tensões desviadoras muito próximas para as tensões confinantes de 50 e $100 \mathrm{kPa}$, no entanto, para a tensão confinante de $200 \mathrm{kPa}$ a mistura 5:1 apresentou tensão desviadora maior que a da mistura 4:1. Esse comportamento pode ser devido ao fato de essas misturas terem sido compactadas com massas secas específicas muito próximas, porém, com teores de umidade distintos (ver Tabela 4.6) e desvios de umidade também distintos, conforme discutido no 4.5.1

As pressões neutras desenvolvidas no cisalhamento das misturas foram positivas, com exceção da mistura 4:1 ensaiada sob tensão confinante de $50 \mathrm{kPa}$ que desenvolveu pressão neutra negativa, porém, muito baixa. Com exceção da mistura $3: 1$, as pressões neutras positivas aumentaram inicialmente, mas diminuíram ao longo do ensaio. Pode-se dizer, então, que as misturas tiveram comportamento de areia medianamente compacta ou de uma argila levemente sobreadensada. 
Figura 4.27 - Resultados do ensaio triaxial não drenado (CAU) na mistura 3:1: curvas tensão-deformação e pressão neutra-deformação.
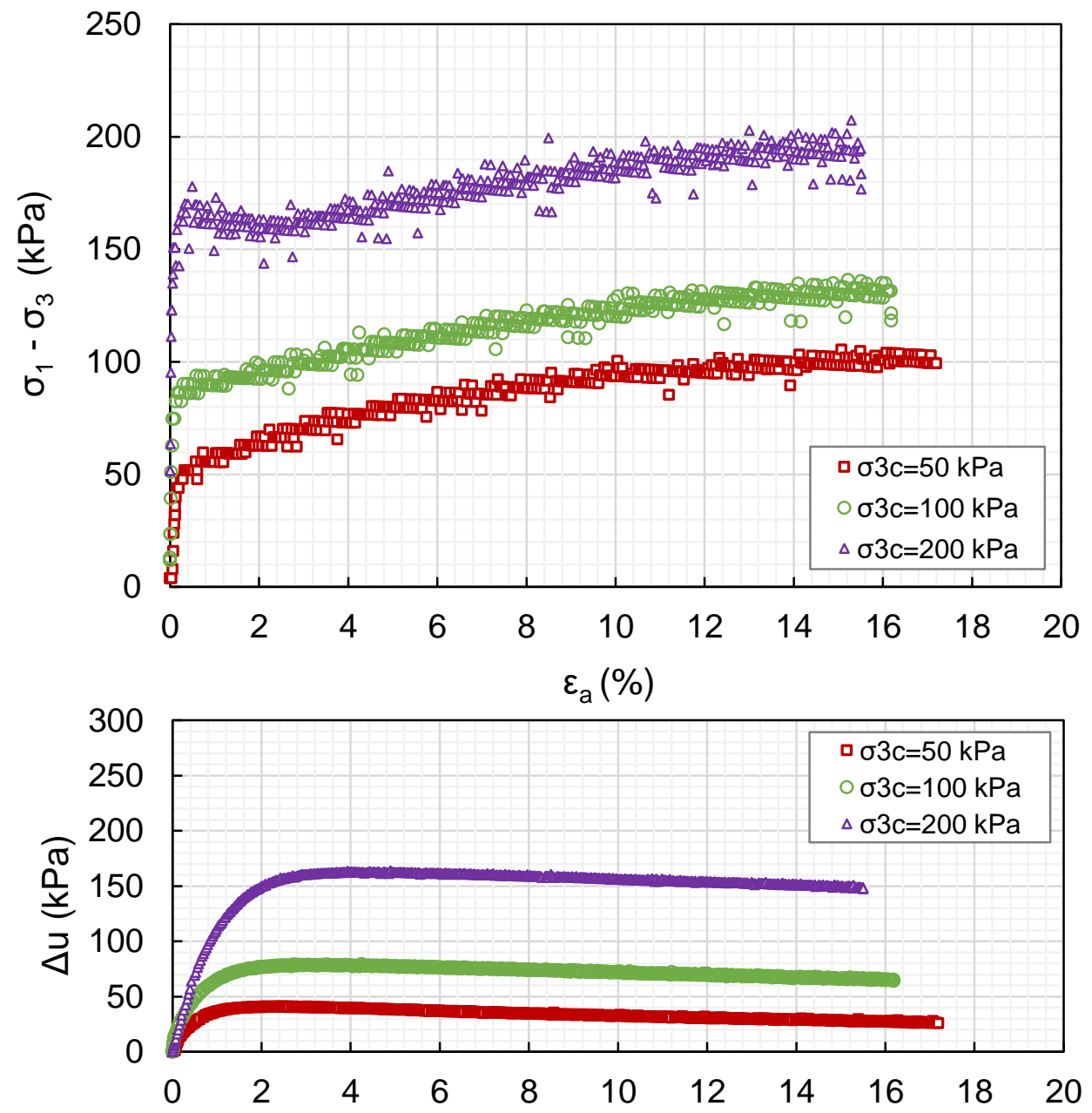
Figura 4.28 - Resultados do ensaio triaxial não drenado (CAU) na mistura 4:1: curvas tensão-deformação e pressão neutra-deformação.
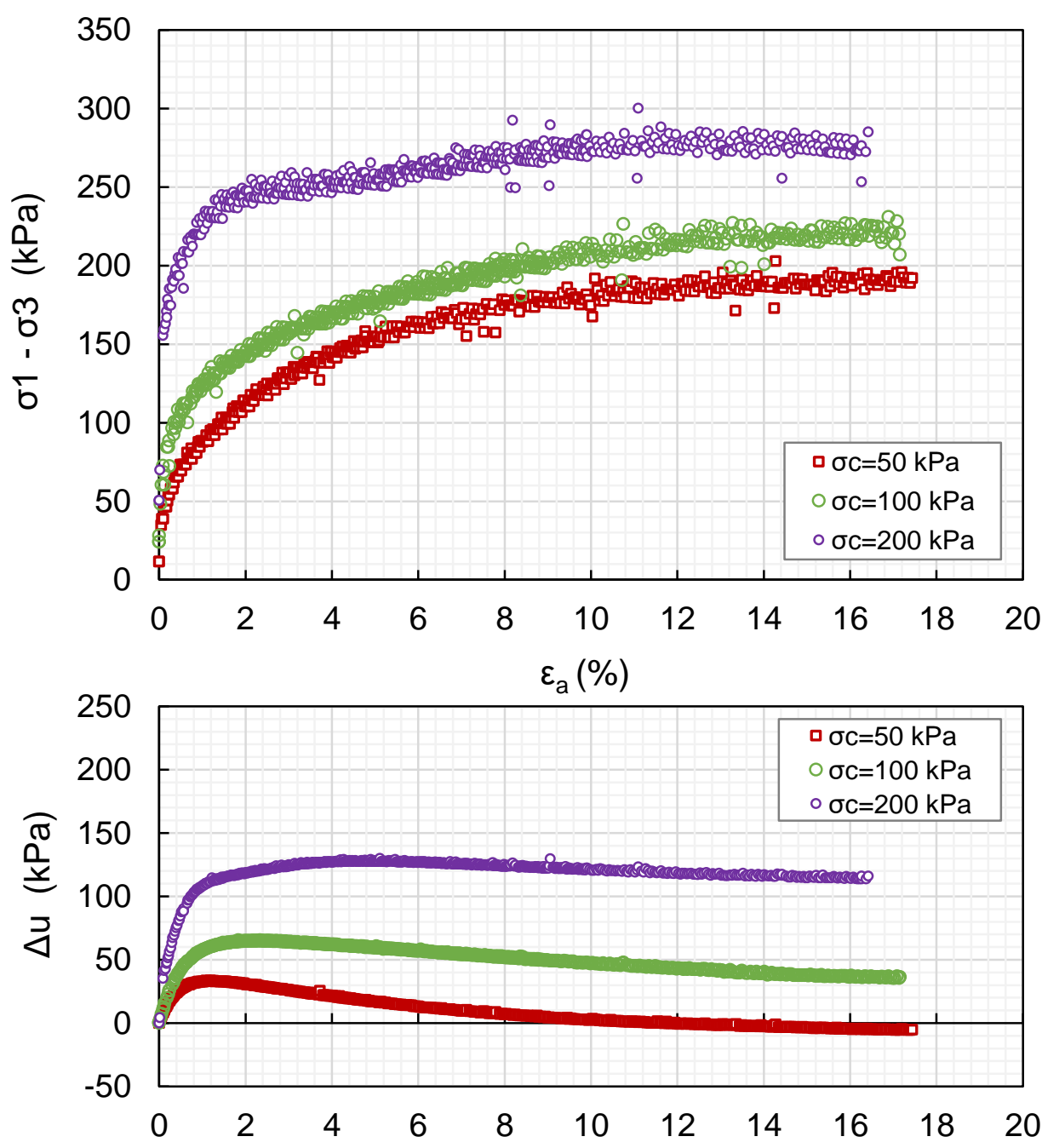
Figura 4.29 - Resultados do ensaio triaxial não drenado (CAU) na mistura 5:1: curvas tensão-deformação e pressão neutra-deformação.
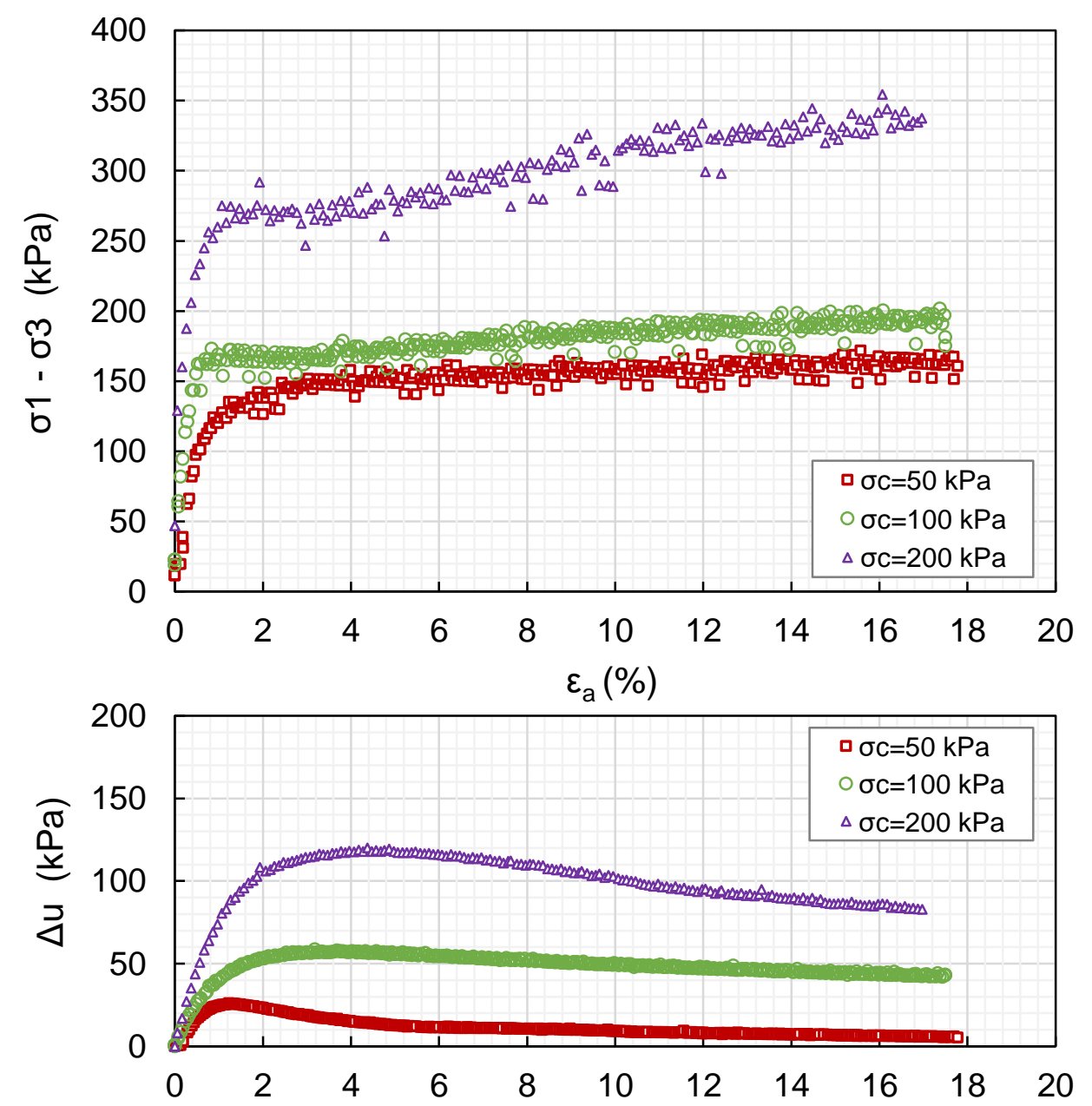

Nas Figuras 4.30 a 4.32 são apresentadas as trajetórias de tensões efetivas dos ensaios triaxiais das misturas e as correspondentes envoltórias de resistência. Nas Figuras 4.33 a 4.35 são apresentados os círculos de Mohr e as correspondentes envoltórias de resistência em termos de tensões efetivas.

Os parâmetros de resistência foram determinados a partir tanto das trajetórias de tensões quanto dos círculos de Mohr empregando o mesmo método utilizado para o solo, apresentado em 4.6.2.

Na Tabela 4.9 é apresentado um resumo dos parâmetros de resistência das misturas e do solo. 
Figura 4.30 - Resultados do ensaio triaxial não drenado (CAU) na mistura 3:1: Diagrama de trajetórias de tensões efetivas.

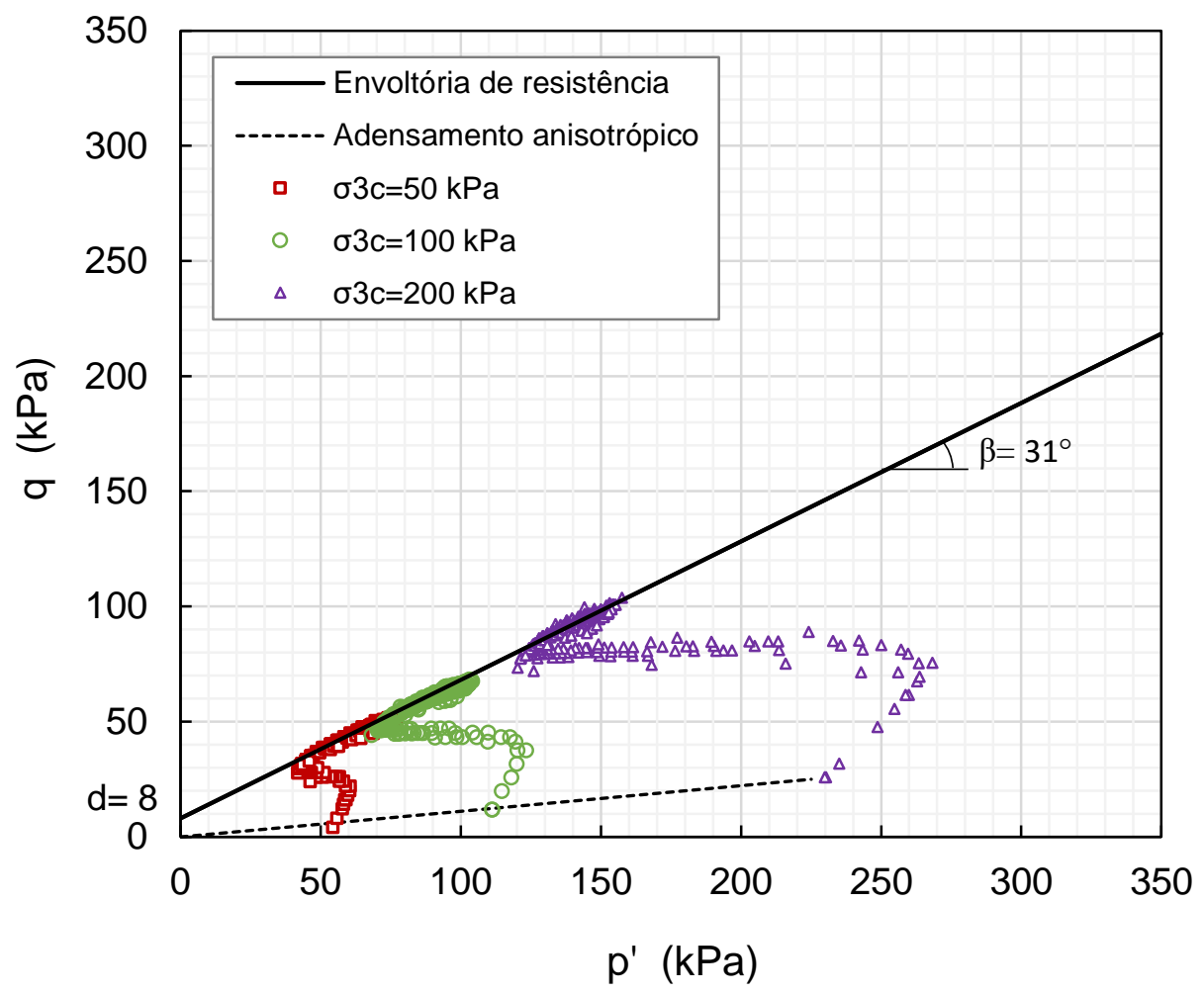

Figura 4.31 - Resultados do ensaio triaxial não drenado (CAU) na mistura 4:1: Diagrama de trajetórias de tensões efetivas.

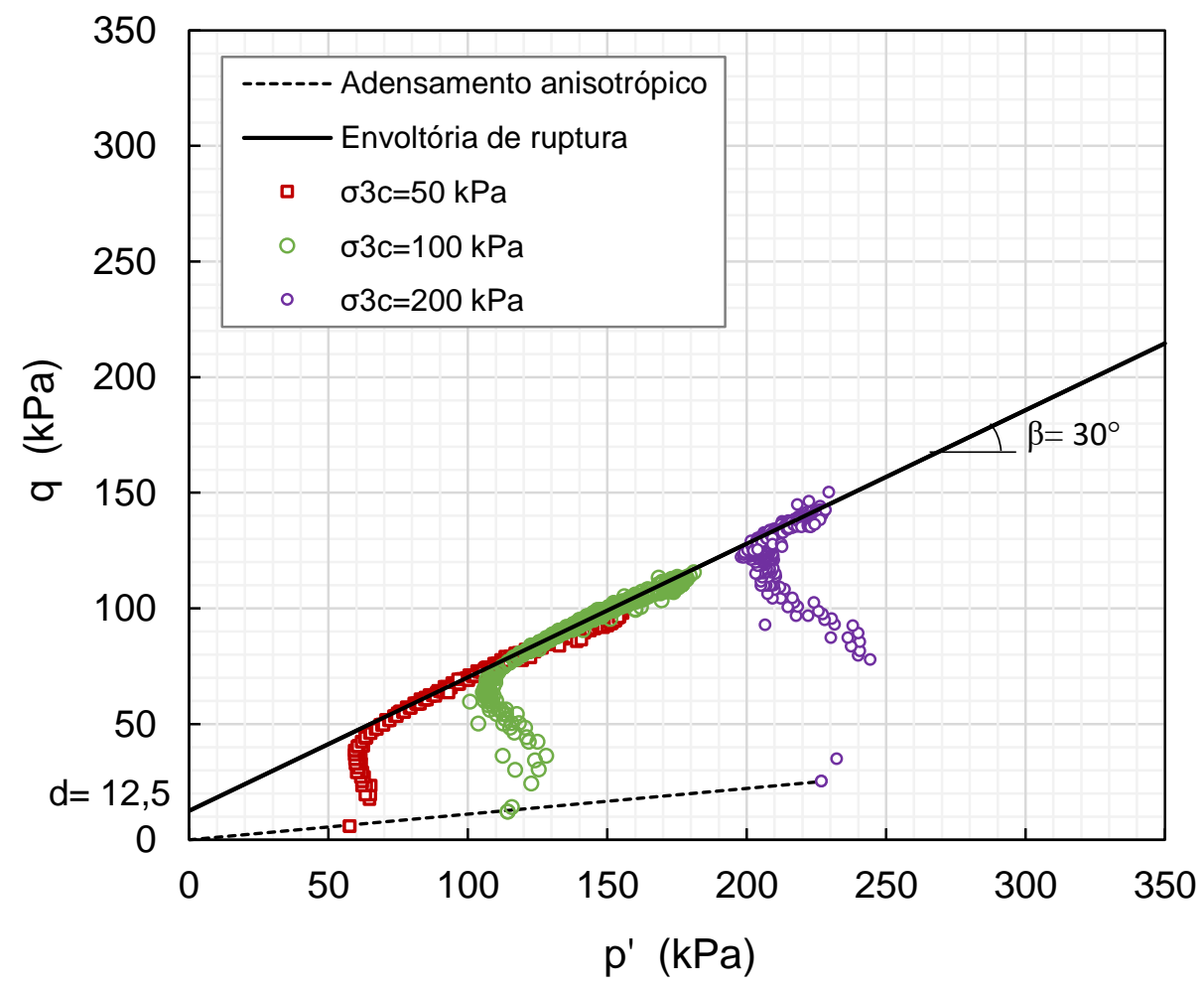


Figura 4.32 - Resultados do ensaio triaxial não drenado (CAU) na mistura 5:1: Diagrama de trajetórias de tensões efetivas.

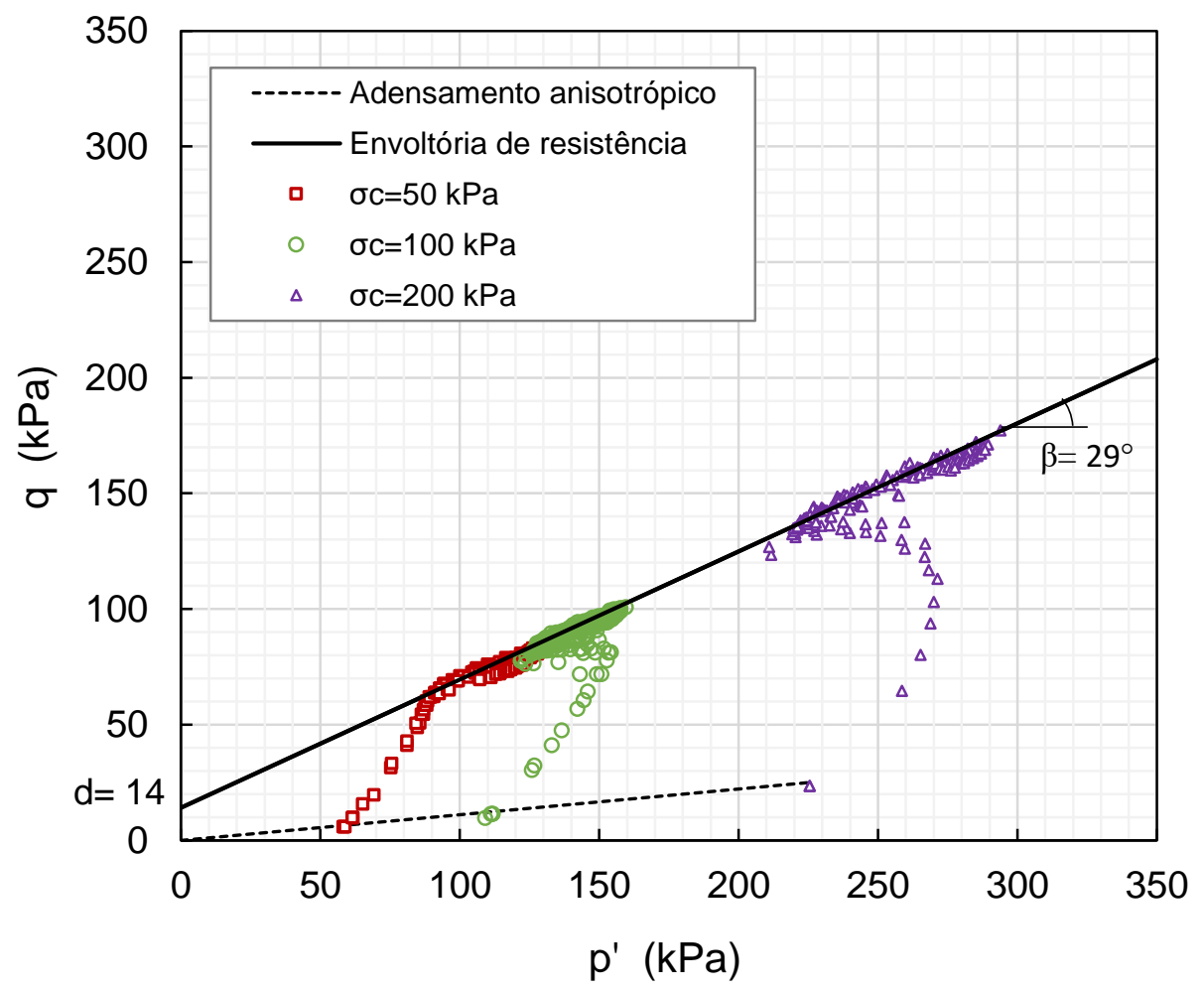

Figura 4.33 - Círculos de Mohr e envoltória de resistência em termos de tensões efetivas da mistura 3:1.

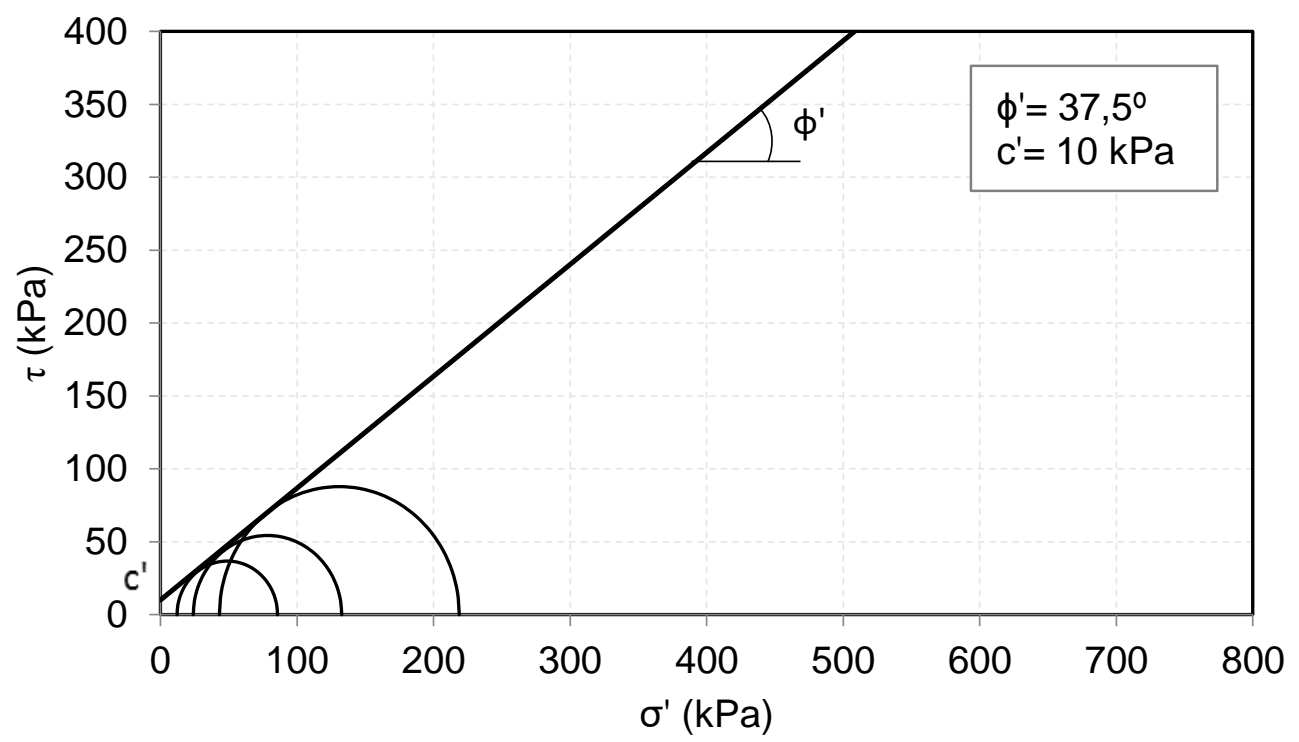


Figura 4.34 - Círculos de Mohr e envoltória de resistência em termos de tensões efetivas da mistura 4:1.

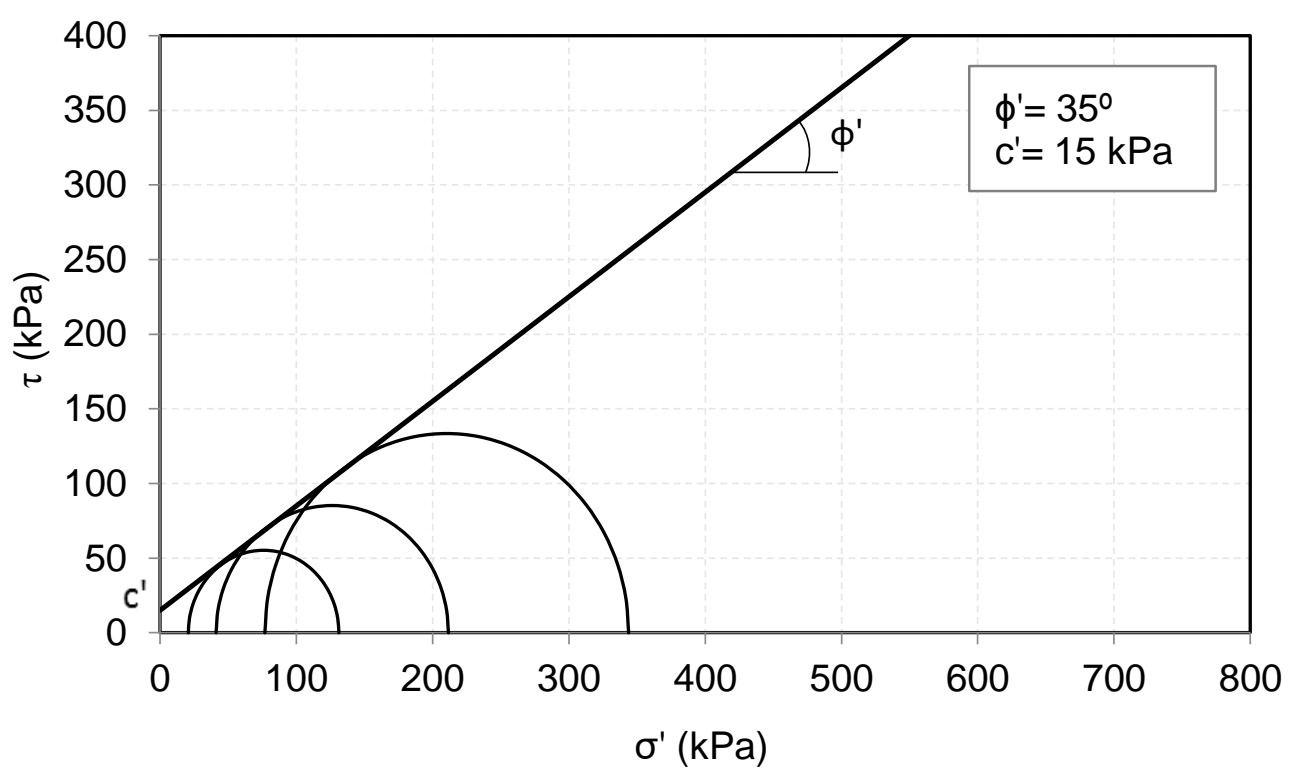

Figura 4.35 - Círculos de Mohr e envoltória de resistência em termos de tensões efetivas da mistura 5:1.

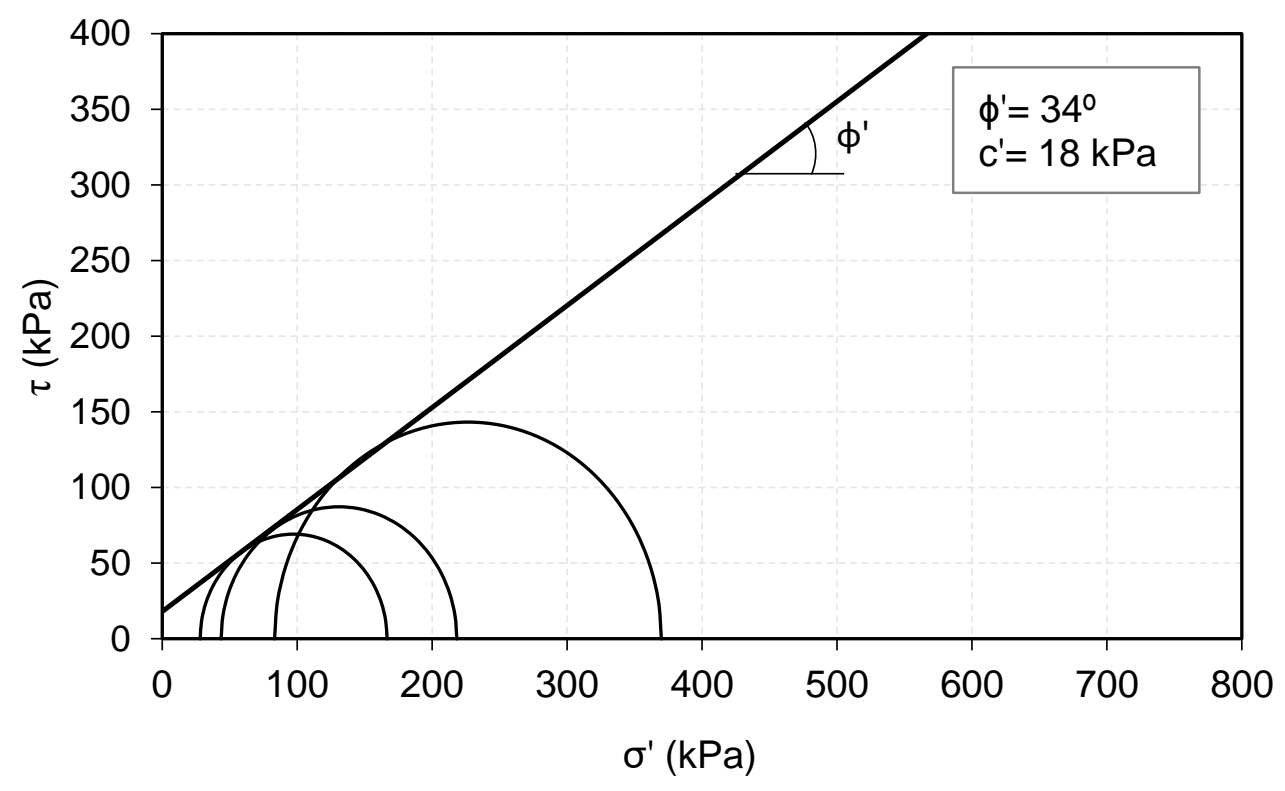


Tabela 4.9 - Parâmetros de resistência em termos de tensões efetivas das misturas e do solo.

\begin{tabular}{llcccc}
\hline Parâmetro & Material & Mistura 3:1 & Mistura 4:1 & Mistura 5:1 & Solo \\
\hline Trajetória de & $\varphi^{\prime}\left(^{\circ}\right)$ & 37 & 35 & 34 & 34 \\
tensões & $c^{\prime}(\mathrm{kPa})$ & 10 & 15 & 17 & 22 \\
Círculo de & $\varphi^{\prime}\left(^{\circ}\right)$ & 37,5 & 35 & 34 & 34 \\
Mohr & $c^{\prime}(\mathrm{kPa})$ & 10 & 15 & 18 & 22 \\
\hline
\end{tabular}

Pode-se observar que os parâmetros de resistência determinados a partir da envoltória de resistência definida nos diagramas de trajetória de tensões concordam com os valores determinados a partir das envoltórias definidas nos círculos de Mohr.

O solo e a mistura 5:1 apresentaram o menor ângulo de atrito efetivo, com um valor de 34, mas apresentaram os maiores valores de coesão efetiva, 22 e $18 \mathrm{kPa}$, respectivamente. A mistura 3:1 apresentou o maior ângulo de atrito, com um valor de 37, e o menor valor de coesão efetiva, $10 \mathrm{kPa}$. A mistura 4:1 apresentou ângulo de atrito efetivo e coesão efetiva com valores intermediários respectivamente de 35 e 15 $\mathrm{kPa}$. Esses resultados indicam que quanto maior a quantidade de lodo presente na mistura maior é o ângulo de atrito efetivo e menor a coesão efetiva.

Os valores dos parâmetros de resistência de lodos de ETA determinados por diversos autores (WANG et al., 1992; ROQUE; CARVALHO, 2006; O'KELLY, 2008; O'KELLY; QUILLE, 2010) têm variado entre $39^{\circ}$ a $44^{\circ} \mathrm{com}$ valor médio de $42^{\circ}$, para o ângulo de atrito efetivo, e entre 0 a $77 \mathrm{kPa}$ com valor médio de $11,2 \mathrm{kPa}$, para a coesão efetiva.

Esses valores típicos dos parâmetros de resistência do lodo de ETA, elevado ângulo de atrito efetivo e baixa coesão efetiva, poderiam explicar o aumento do primeiro e a diminuição do segundo nas misturas na medida em que o teor de lodo na mistura é maior. Em outras palavras, com o aumento do teor de lodo nas misturas, o ângulo de atrito tende a valores próximos de $40^{\circ}$ e a coesão a valores próximos de 0 (zero).

Comparando os parâmetros de resistência obtidos para as misturas com aqueles dos solos residuais utilizados na construção de diversas barragens 
apresentados na Tabela 2.16, vemos que as misturas apresentam uma resistência ligeiramente maior. Os valores de ângulo de atrito efetivo e coesão efetiva dos solos residuais (Tabela 2.16) variaram de 26 a $35^{\circ}$ e 5 a $15 \mathrm{kPa}$, respectivamente, e das misturas variaram de 34 a $37^{\circ}$ e de 10 a $22 \mathrm{kPa}$, respectivamente. 


\section{CONCLUSÕES}

- As partículas da fase sólida do lodo da ETA do Município de Cubatão são compostas principalmente pelos minerais de quartzo, goethita, muscovita e caulinita.

- O lodo da ETA do Município de Cubatão apresenta elevada concentração de cálcio e ferro, explicável pela utilização de cloreto férrico e cal no tratamento da água. Adicionalmente, o lodo tem pH neutro, CTC elevada, e baixo teor de matéria orgânica, com valores similares aos reportados por outros autores.

- O solo é classificado como SC e o lodo como MH pelo SUCS. Todas as misturas (3:1, 4:1 e 5:1) são classificadas como SC, como o solo. A adição de lodo não altera significativamente a granulometria, a massa específica dos grãos e os limites de consistência do solo.

- A secagem ao ar do lodo é muito demorada (cerca de 40 dias para atingir a umidade residual de 14\%) e o lodo muda drasticamente sua estrutura e granulometria convertendo-se em material não plástico com partículas de tamanho de pedregulho.

- As misturas 3:1, 4:1 e 5:1 compactadas com energia normal na umidade de mistura apresentam menor massa específica seca que o solo no ponto ótimo.

- A umidade inicial no ensaio de compactação obtida por secagem ao ar a partir da umidade de mistura influi nos parâmetros de compactação: a massa específica seca máxima aumenta e o teor de umidade ótimo diminui com a redução do teor de umidade inicial no ensaio de compactação.

- Obtiveram-se correlações com coeficientes de determinação $r^{2}$ maiores que 0,90 da massa específica seca máxima e do teor de umidade ótimo em função da umidade inicial no ensaio de compactação.

- Por meio de secagem prévia é possível obter para qualquer das misturas estudadas valores de massa específica seca máxima muito próximos ao do solo.

- As misturas compactadas na umidade de mistura são mais compressíveis que o solo compactado na umidade ótima (índice de compressão do solo 0,07 e das misturas variando de 0,13 a 0,19 ). No entanto, o índice de recompressão é praticamente o mesmo para o solo $(0,02)$ e as misturas $(0,02$ a 0,03$)$. 
- Os valores de condutividade hidráulica das misturas 4:1 e 5:1 são ligeiramente menores $\left(0,9 \times 10^{-7}\right.$ a $\left.3,0 \times 10^{-6} \mathrm{~m} / \mathrm{s}\right)$ que a do solo $\left(3,9 \times 10^{-7}\right.$ a $\left.6,9 \times 10^{-6} \mathrm{~m} / \mathrm{s}\right)$ para as condições de pressão confinante e gradiente hidráulico estudadas.

- A mistura solo-lodo na proporção 3:1 tem coeficiente de condutividade hidráulica da ordem de $10^{-9} \mathrm{~m} / \mathrm{s}$ e pode com o tempo colmatar meios porosos adjacentes impedindo a percolação d'água, como ocorrido no ensaio de permeabilidade.

- O ângulo de atrito efetivo das misturas aumenta $\left(34^{\circ}\right.$ a $\left.37^{\circ}\right)$ e a coesão efetiva diminui (10 a $17 \mathrm{kPa}$ ) à medida que for maior a proporção de lodo acrescentado ao solo ( $34^{\circ}$ e $\left.22 \mathrm{kPa}\right)$.

- As características e parâmetros geotécnicos das misturas solo-lodo nas proporções 3:1, 4:1 e 5:1, compactadas nas correspondentes umidades de mistura, apresentam valores aceitáveis para solos utilizados em aterros, em barragens, em camadas de cobertura diária de aterros sanitários e em alguns casos até em camadas de cobertura final.

- A mistura 3:1 apresenta condutividade hidráulica aceitável para uso como material de revestimento de fundo (camada de impermeabilização) em aterros sanitários, porém, as misturas 4:1 e 5:1 não apresentam valores aceitáveis para serem utilizados nesse tipo de aplicação.

- Embora os valores dos parâmetros geotécnicos da mistura 3:1 sejam aceitáveis, há ainda que se considerar sua maior deformabilidade e que a elevada umidade de mistura dificulta a trabalhabilidade do material em campo. 


\section{RECOMENDAÇÕES}

A seguir, são listadas as principais sugestões para prosseguimento da pesquisa:

- Estudar a viabilidade ambiental do uso de misturas solo-lodo em obras geotécnicas mediante ensaios de lixiviação.

- Pesquisar os benefícios da utilização de cal nas misturas. A cal é amplamente utilizada como material para estabilização e melhoramento das propriedades geotécnicas de solos e pode se apresentar economicamente viável devido ao seu baixo custo.

- Investigar os efeitos da secagem ao ar das misturas nos parâmetros geotécnicos (deformabilidade, permeabilidade e resistência ao cisalhamento).

- Estudar métodos de mistura do solo com lodo de ETA em campo assim como também a trabalhabilidade do material nas umidades de mistura. É importante determinar o método e os equipamentos mais adequados para misturar os materiais e manejar as misturas.

- A mistura 3:1 apresentou-se muito pouco permeável o que pode ser de grande vantagem em algumas obras, por exemplo em revestimento de fundo em aterros sanitários ou industriais, no entanto também apresentou-se mais compressível que as outras misturas dado seu elevado teor de umidade. Nessa perspectiva recomenda-se estudar o trincamento por secagem e a deformabilidade da mistura 3:1 visando seu uso como material de revestimento de fundo ou cobertura.

- Determinar a variação das características geotécnicas (massa específica dos grãos, granulometria e limites de consistência) do lodo da ETA do Município de Cubatão ao longo do ano. Se houver variações significativas, investigar então os efeitos dessas variações no comportamento geotécnico das misturas já estudadas (3:1, 4:1, e 5:1).

- Os valores dos parâmetros geotécnicos foram obtidos a partir de misturas solo-lodo nas proporções 3:1, 4:1 e 5:1 preparadas com o solo na umidade higroscópica (1\%) e o lodo na umidade in natura (350\%). Recomenda-se investigar misturas com valores incrementais de umidade do solo, dado que no campo o solo pode estar com teor de umidade bem acima do higroscópico. 


\section{REFERÊNCIAS}

AMERICAN SOCIETY FOR TESTING AND MATERIALS - ASTM. ASTM D5084-00: Standard Test Methods Measurement of Hydraulic Conductivity of Saturated Porous Materials Using a Flexible Wall Permeameter. ASTM International, West Conshohocken, PA, 2000, 23p.

ASTM D0698-00ae1: Standard Test Methods for Laboratory Compaction Characteristics of Soil Using Standard Effort (12,400 ft-lbf/ft3 $(600 \mathrm{kN}-\mathrm{m} / \mathrm{m3}))$, ASTM International, West Conshohocken, PA, 2000, 11p.

ASTM D4767-04: Standard Test Method for Consolidated Undrained Triaxial Compression Test for Cohesive Soils. ASTM International, West Conshohocken, 2004, 13p.

ASSOCIAÇÃO BRASILEIRA DE NORMAS TÉCNICAS - ABNT. NBR 6459: Determinação do Limite de Liquidez. Rio de Janeiro, 1984, 6p.

NBR 6508: Grãos de solos que passam na peneira de 4,8 mm Determinação da massa específica, Rio de Janeiro, 1984, 8p.

NBR 6457: Amostras de solo - Preparação para ensaios de compactação e ensaios de caracterização, Rio de Janeiro, 1986, 9p.

NBR 7180: Determinação do Limite de Plasticidade, Rio de Janeiro, 1988, $3 p$.

NBR 7181: Solo - Análise granulométrica, Rio de Janeiro, 1988, 13p.

NBR 12007: Solo - Ensaio de adensamento unidimensional - Método de ensaio, Rio de Janeiro, 1988, 13p.

NBR 7182: Solo - Ensaio de compactação, Rio de Janeiro, 1988, 10p.

NBR 13896: Solo - Aterros de resíduos não perigosos - Critérios para projeto, implantação e operação, Rio de Janeiro, 1997, 12p.

NBR 10004: Resíduos sólidos - Classificação, Rio de Janeiro, 2004, 71p.

ABDO, M. S. E.; EWIDA, K. T.; YOUSSEF, Y. M. Recovery of alum from wasted sludge produced from water treatment plants. Journal of Environmental Science \& Health Part A, v. 28, n. 6, p. 1205-1216, 1993.

AHMAD, T.; AHMAD, K.; ALAM, M. Characterization of Water Treatment Plant's Sludge and its Safe Disposal Options. Procedia Environmental Sciences, v. 35, p. 950-955, 2016. 
AYDILEK, A. H.; EDIL, T. B.; FOX, P. J. Consolidation characteristics of wastewater sludge. ASTM Special Technical Publication, n. 1374, p. 309-323, 1999.

AZEVEDO NETTO, J. M. Tratamento de águas de abastecimento. São Paulo: Editôra da Universidade de São Paulo, 1966.

BABATUNDE, A. O.; ZHAO, Y. Q. Constructive Approaches Toward Water Treatment Works Sludge Management: An International Review of Beneficial Reuses. Critical Reviews in Environmental Science and Technology, v. 37, n. 2, p. 129-164, 2007.

BASIBUYUK, M.; KALAT, D. G. The use of waterworks sludge for the treatment of vegetable oil refinery industry wastewater. Environmental technology, v. 25, n. 3, p. 373-380, 2004.

BASIM, S. C. Physical and geotechnical characterization of water treatment plant residuals. 1999. 104p. Doctoral Thesis - New Jersey Institute of Technology, New Jersey, 1999.

BERNUCCI, L. L. B. Considerações sobre o dimensionamento de pavimentos utilizando solos lateríticos para rodovias de baixo volume de tráfego. Tese (Doutorado) —Escola Politécnica, Universidade de São Paulo, São Paulo, 1995.

BICALHO, K. V.; ZNIDARCIC, D.; KO, H. Y. An experimental evaluation of unsaturated hydraulic conductivity functions for a quasi-saturated compacted soil. XIII Advanced Experimental Unsaturated Soil Mechanics. Proceedings...Trento, Italia: Balkema CRC Press, 2005.

BOSCOV, M. E. G. Brazilian experience in geo-environmental applications of tropical soils. 6ICEG-6th International Congress on Environmental Geotechnics, Proceedings, Keynote Lecture. Proceedings...2010

BRADY, N. C.; WEIL, R. R. The nature and properties of soils. Rev. 14. ed ed. Upper Saddle River, NJ: Pearson/Prentice Hall, 2008.

CALRECYCLE, C. D. OF R. R. AND R. Daily/Intermediate Cover and Alternative Daily/Intermediate Cover GuidelinesCalRecycle, 2016. Disponível em: $<$ http://www.calrecycle.ca.gov/SWFacilities/Permitting/Guidance/DailylntCovr/default. htm>

CETESB. Relatório de Qualidade das Águas Superficiais do Estado de São Paulo: Relatórios. Sao Paulo: CETESB, 2009. Disponível em: <http://www.cetesb.sp.gov.br/agua/aguas-superficiais/35-publicacoes-/-relatorios>. Acesso em: 10 maio. 2016.

CHEN, H.; MA, X.; DAI, H. Reuse of water purification sludge as raw material in cement production. Cement and Concrete Composites, v. 32, n. 6, p. 436-439, 2010.

CORDEIRO, J. S. Importância do tratamento e disposição adequada dos lodos de ETAs. In: REALI, M. A. P. (Ed.). Noções gerais de tratamento e disposição final 
de lodos de estações de tratamento de água. 1ra. ed. Rio de Janeiro: ABES, 1999. p. $1-19$.

CORNWELL, D. A.; BISHOP, M. M.; GOULD, R. G.; VANDERMEYDEN, C. Handbook of practice, water treatment plant waste management. Denver, Colo: American Water Works Association, 1987.

CORNWELL, D. A.; VANDERMEYDEN, C.; DILLOW, G.; WANG, M. Landfilling of water treatment plant coagulant sludges. Denver, Colorado: AWWA Research Foundation and American Water Works Association, 1992.

CORNWELL, D. A. Water Treatment Residuals Engineering. AWWA Research Foundation and American Water Works Association, 2006.

CORNWELL, D. A.; MUTTER, R. N.; VANDERMEYDEN, C. Commercial application and marketing of water plant residuals. American Water Works Association, 2000.

CRUZ, P. T. DA. Propriedades de engenharia de solos residuais compactados da região Centro-Sul do Brasil. THEMAG/DLP/EPUSP, 1967.

DA SILVA, J. F. A. Comportamento de concreto asfáltico tendo lodo da ETA da cidade de Manaus como fíler. 2008. 180 p. Dissertação (Mestrado) - Universidade Federal do Amazonas, Manaus, 2008.

DANIEL, D. E. Geotechnical Practice for Waste Disposal. Boston, MA: Springer US, 1993.

DAYTON, E. A.; BASTA, N. T. Characterization of Drinking Water Treatment Residuals for Use as a Soil Substitute. Water Environment Research, v. 73, n. 1, p. 52-57, 2001.

DE CASTILHOS JUNIOR, A. B.; PRIM, E. C. C.; PIMENTEL, F. J. G. Utilização de lodo de ETA e ETE como material alternativo de cobertura de aterro sanitário. Estudos Tecnológicos em Engenharia, v. 7, n. 2, p. 86-97, 2011.

DHARMAPPA, H. B.; HASIA, A.; HAGARE, P. Water treatment plant residuals management. Water science and technology, v. 35, n. 8, p. 45-56, 1997.

DI BERNARDO, L. Métodos e técnicas de tratamento de água. ABES, v. 1. 1993.

DI BERNARDO, L.; CARVALHO, E. DE; SCALIZE, P. Disposição de resíduos líquidos de ETAs em ETEs. Noções Gerais de Tratamento e Disposição Final de Lodos de Estações de Tratamento de Água. Prosab, 1999.

DI BERNARDO, L.; DI BERNARDO, A. Métodos e técnicas de tratamento de água. 2da. ed. São Carlos: Rima Editora, v. 1. 2005.

DOE. Waste Management Paper 26B - Landfill Design, Construction and Operational Practice. HMSO, London, 1995. 
DONAGHE, R. T.; TOWNSEND, F. C. Effects of anisotropic versus isotropic consolidation in consolidated-undrained triaxial compression tests of cohesive soils. 1978.

EMBRAPA. Manual de métodos de análise de solo. 2da. ed. Rio de Janeiro: Embrapa Solos, 1997.

FADIGAS, F. DE S.; AMARAL-SOBRINHO, N. M. B.; MAZUR, N.; ANJOS, L. H. C.; FREIXO, A. A. Natural contents of heavy metals in some brazilian soil classes. Bragantia, v. 61, n. 2, p. 151-159, ago. 2002.

FOTH, H. D. Fundamentals of soil science. 8th. ed. John Willey \& Sons, 1991.

GIVEN, P. W.; SPINK, D. Alum Sludge: Treatment Disposal and Characterization. Proceedings, 36th Annual Western Canada Water and Sewage Conference. Proceedings...1984

GOLDBOLD, P. LEWIN, K.; GRAHAM, A.; BARKER, P. The potential reuse of water utility products as secondary commercial materials. WRc Report No. UC, v. 6081, 2003.

GORDON, M. E. Design and performance monitoring of clay-lined landfills. Geotechnical Special Publication n. 13. Proceedings... In: GEOTECHNICAL PRACTICE FOR WASTE DISPOSAL'87. ASCE, 1987.

GUERRA, R. C. Caracterização e biodegradação de lodo de estações de tratamento de água para descarte em aterro sanitário. 2005. 88 p. Dissertação (Mestrado) -Universidade Estadual Paulista "Julio de Mesquita Filho", Rio Claro, 2005.

HAZELTON, P. A.; MURPHY, B. W. Interpreting Soil Test Results: What Do All the Numbers Mean? Csiro Publishing, 2007.

HEIL, D. M.; BARBARICK, K. A. Water treatment sludge influence on the growth of sorghum-sudangrass. Journal of environmental Quality, v. 18, n. 3, p. 292-298, 1989.

HELLER, L.; PÁDUA, V. L. Abastecimento de água para consumo humano. Editora UFMG, 2006.

HOLTZ, R. D.; KOVACS, W. D. An Introduction to Geotechnical Engineering. Prentice-Hall, 1981.

HOPPEN, C.; PORTELLA, K. F.; JOUKOSKI, A.; BARON, O.; FRANCK. R.; SALES, A.; ANDREOLI, C. V.; PAULON, V. A. Co-disposição de lodo centrifugado de Estação de Tratamento de Água (ETA) em matriz de concreto: método alternativo de preservação ambiental. Cerâmica, v. 51, n. 318, p. 85-95, 2005.

HSIEH, H. N.; RAGHU, D. Criteria Development for Water Treatment Plant Residual Monofills. American Water Works Association, 1997. 
IBGE, I. B. Pesquisa Nacional de Saneamento Básico 2008. Rio de Janeiro, 2008.

IBGE - INSTITUTO BRASILEIRO DE GEOGRAFIA E ESTATÍSTICA. Manual Técnico de Pedologia. IBGE Rio de Janeiro, 2007.

IBGE, INSTITUTO BRASILEIRO DE GEOGRAFIA E ESTATí́sTICA. Mapa de Solos do Brasil, 2001.

ICDD, I. C. FOR D. D. The Powder Diffraction File, PDF-2. ICDD Newtown Square, PA, 2003.

JANUÁRIO, G. F. Planejamento e aspectos ambientais envolvidos na disposição final de lodos das estações de tratamento de água da Região Metropolitana de São Paulo. 2005. Dissertação (Mestrado) -Universidade de São Paulo, São Paulo, 2005.

KIKUCHI, R. Recycling of municipal solid waste for cement production: pilot-scale test for transforming incineration ash of solid waste into cement clinker. Resources, Conservation and Recycling, v. 31, n. 2, p. 137-147, 2001.

LAMBE, T. W.; WHITMAN, R. V. Soil Mechanics. 2nd. ed. John Wiley, New York, 1969.

LUCENA, L. C. DE F. L.; JUCA, J. F. T.; SOARES, J. B.; MARINHO FILHO, P. G. T. Use of wastewater sludge for base and subbase of road pavements. Transportation Research Part D: Transport and Environment, v. 33, p. 210-219, 2014.

MACHADO, L.; PEREIRA, J. A. R.; PONTE, M. X.; LOPES, L. N. A. Avaliação do aproveitamento agrícola do lodo produzido na ETA Bolonha-RMB. ICTR 2004Congresso Brasileiro de Ciência e Tecnologia em Resíduos e Desenvolvimento Sustentável. Anais...2004.

MARTINEZ, J. G. B. Avaliação de desempenho de misturas betuminosas com adição de lodos de eta e de ete. 2014. 97 p. Dissertação (Mestrado) -Universidade de Brasília, Brasília, 2014.

MASSAD, F. Baixada Santista: implicações da história geológica no projeto de fundações. Solos e Rochas: Revista Latino Americana de Geotecnia, v. 22, n. 1, p. 3-49, 1999.

METCALF, L.; HARRISON, E. Ingeniería sanitaria: tratamiento, evacuación y reutilización de aguas residuales. 2da. ed. Barcelona: Labor, 1985.

MITCHELL, J. K.; SOGA, K. Fundamentals of soil behavior. 3rd ed ed. Hoboken, N.J: John Wiley \& Sons, 2005.

MONTEIRO, S. N.; ALEXANDRE, J.; MARGEM, J. I.; SÁNCHEZ, R.; VIEIRA, C. M. F. Incorporation of sludge waste from water treatment plant into red ceramic. Construction and Building Materials, v. 22, n. 6, p. 1281-1287, 2008. 
MOREIRA, R. C. A.; GUIMARÃES, E. M.; BOA AVENTURA, G. R.; MOMESSO, A. M.; DE LIMA, G. L. Estudo geoquímico da disposição de lodo de estação de tratamento de água em área degradada. Quim. Nova, v. 32, n. 8, p. 2085-2093, 2009.

MORITA, D. M.; SAMPAIO, A. O.; MIKI, M. K.; DAVID, A. C. Incorporação de lodos de estações de tratamento de água em blocos cerâmicos. Revista Saneas, v. 1, n. 14, 2002.

MURRAY, E. J.; DIXON, N.; JONES, D. R. V. Properties and testing of clay liners. Geotechnical Engineering of Landfills: Proceedings of the Symposium Held at the Nottingham Trent University Department of Civil and Structural Engineering on 24 September 1998. Proceedings...Thomas Telford Services Limited, 1998.

MURRAY, E. J.; RIX, D. W.; HUMPHREY, R. D. Clay linings to landfill sites. Quarterly Journal of Engineering Geology and Hydrogeology, v. 25, n. 4, p. 371376, 1992.

NOGAMI, J. S.; VILLIBOR, D. F. Pavimentação de baixo custo com solos lateríticos. São Paulo: Villibor, 1995.

NRA. Policy and practice for the protection of groundwaters. National Rivers Authority, Bristol, 1992.

O'KELLY, B. C. Geotechnical properties of a municipal water treatment sludge incorporating a coagulant. Canadian Geotechnical Journal, v. 45, n. 5, p. 715-725, 2008.

O'KELLY, B. C.; QUILLE, M. E. Compressibility and consolidation of water treatment residues. Proceedings of the ICE-Waste and Resource Management, v. 162, n. 2, p. 85-97, 2009.

O'KELLY, B. C.; QUILLE, M. E. Shear strength properties of water treatment residues. Proceedings of the ICE-Geotechnical Engineering, v. 163, n. 1, p. 23-35, 2010.

OLIVEIRA, E. M. S.; MACHADO, S. Q.; HOLANDA, J. N. F. Caracterização de resíduo (lodo) proveniente de estação de tratamento de águas visando sua utilização em cerâmica vermelha. Cerâmica, v. 50, p. 324-330, 2004.

OLIVEIRA, N. S. Estudo da secagem de lodo de estação de tratamento de água. 2010. 208 p. Dissertação (Mestrado) —Universidade Federal do Paraná, Curitiba, 2010.

PAN-ICSD. PANalitycal Inorganic Cristal Structure Database (ICSD). [s.I.] Fachinformationszentrum Karlsruhe (FIZ) and National Institute of Standards and Technology (NIST), 2007.

PETRUZZELLI, D.; VOLPE, A; LIMONI, N.; PASSINO, R. Coagulants removal and recovery from water clarifier sludge. Water Research, v. 34, n. 7, p. 2177-2182, 2000. 
PINTO, C. DE S. Curso básico de mecânica dos solos: em 16 aulas. 3. ed., com exercícios resolvidos ed. São Paulo, SP: Oficina de Textos, 2006.

PORTELLA, K. F.; ANDREOLI, C. V.; HOPPEN, C.; SALES; A.; BARON, O. Caracterização físico-química do lodo centrifugado da estação de tratamento de água Passaúna-Curitiba-PR. Congresso Brasileiro de Engenharia Sanitária Ambiental. Anais...2003.

PRIM, E. C. C. Utilização de lodo de estações de tratamento de água e esgoto como material de cobertura de aterro sanitário. 2011. 285p. Tese (Doutorado) Universidade Federal de Santa Catariana, Florianópolis, 2011.

QASIM, S. R.; CHIANG, W. Sanitary landfill leachate: generation, control, and treatment. Lancaster, Pa: Technomic Pub. Co, 1994.

RAGHU, D.; HSIEH, H.; NEILAN, T.; YIH, C. Water treatment plant sludge as landfill liner. Geotechnical Practice for Waste Disposal'87. Anais...ASCE, 1987.

ROCCA, A. C. C.; IACOVONE, A. M. M.; BARROTTI, A. J. Resíduos sólidos industriais. 2 ed ed. São Paulo, SP: CETESB, 1993.

RODRIGUEZ, T. T.; TEIXEIRA, R. S.; FERNANDEZ, F; OLIVEIRA JUNIOR, O. R.; MARTINS, F. B.; KOMORIN, E. T.; DANZIGUER, D. H. Estudo da compactação de lodo de ETA para uso em aterros sanitários. VII CONGRESSO BRASILEIRO DE GEOTECNIA AMBIENTAL - REGEO. Anais...Belo Horizonte, 2011.

ROQUE, A. J.; CARVALHO, M. Possibility of using the drinking water sludge as geotechnical material. Proceedings of the 5th International Congress on Environmental Geotechnics. Anais...2006.

SABESP. Tratamento de águas. 2016. Disponível em: $<$ http://site.sabesp.com.br/site/interna/Default.aspx?secaold=47>. Acesso em: 5 maio. 2016

SANDOVAL, L.; FLORES, L. M.; MONTELLANO, L.; MORÁN, M. A.; RUBÍ, R.; SÁNCHEZ, L.; SANTANA, M. L.; VÁSQUEZ, S.; MARTÍN, A. Tratabilidad de los lodos producidos en la potabilización del agua. CONGRESSO INTERAMERICANO DE INGENIERIA SANITÁRIA Y AMBIENTAL, XXVI. Anais...1998.

SANTOS, I. S. S. DOS; RAMIRES, M. V. V.; KAZMIERCZAK, C. S.; SILVA, H. C.; KERN, A. P.; CAMARGO, S. A. Caracterizaçâo e identificaçâo do resíduo: lodo da estaçâo de tratamento do Município de Sâo Leopoldo. In: CONGRESO INTERAMERICANO DE INGENIERÍA SANITARIA Y AMBIENTAL, 27. ABES, dez. 2000.

SARON, A.; LEITE, V. M. B. Quantificação de lodo em estação de tratamento de água. In: CONGRESSO BRASILEIRO DE ENGENHARIA SANITÁRIA E AMBIENTAL, 21FEIRA INTERNACIONAL DE TECNOLOGIAS DE SANEAMENTO AMBIENTAL, 4. ABES, 2001. 
SILVA, S. M. C. P.; FERNANDES, F. Co-compostagem de biosólidos, lodo de tratamento de água e resíduos de podas de árvores. Gestión ambiental en el siglo XXI. Anais...APIS, 1998.

SILVA JR, A. P.; ISAAC, R. DE L. Adensamento por gravidade de lodo de ETA gerado em decantador convencional e decantador laminar. Congreso Interamericano de Ingeniería Sanitaria y Ambiental, 28. Anais...FEMISCA, 2002.

SILVEIRA, C.; KURODA, E. K.; ABE, C. H.; YOSHIAKI, L.; HIROOKA, E. Y. Desaguamento do lodo de estações de tratamento de água por leito de drenagem/secagem. Engenharia Sanitaria e Ambiental, v. 20, n. 2, p. 297-306, 2015.

TARTARI, R.; DÍAZ-MORA, N.; MONDÉNES, A. Lodo gerado na estação de tratamento de água Tamanduá, Foz do Iguaçú, PR, como aditivos em argila para cerâmica vermelha. Parte I: Caracterização do lodo e de argilas do terceiro planalto paranaense. Cerâmica, v. 57, n. 343, p. 288-293, 2011.

TEIXEIRA, S. R.; SANTOS, G. T. A.; SOUZA, A. E.; ALESSIO, P.; SOUZA, S. A.; SOUZA, N. R. The effect of incorporation of a Brazilian water treatment plant sludge on the properties of ceramic materials. Applied Clay Science, v. 53, n. 4, p. 561565, out. 2011.

TERZAGHI, K.; PECK, R. B.; MESRI, G. Soil mechanics in engineering practice. John Wiley \& Sons, 1996.

TITSHALL, L. W.; HUGHES, J. C. Characterisation of some South African water treatment residues and implications for land application. Water SA, v. 31, n. 3, p. p299, 2005.

USEPA, U.S. Environmental Protection Agency. Hazardous Waste Management System. Washington D.C.: US Environmental Protection Agency, 1986. v. 40.

USEPA, U.S. Environmental Protection Agency. Criteria for solid waste disposal facilities. U.S. Goverment Printing Office,1993. Disponível em: $<$ https://www.epa.gov/landfills/criteria-solid-waste-disposal-facilities-guideownersoperators $>$. Acesso em: 20 out. 2016

VANDERMEYDEN, C.; CORNWELL, D. A. Nonmechanical Dewatering of Water Plant Residuals. AWWA Research Foundation and American Water Works Association, 1998.

WANG, M. C.; HULL, J. Q.; JAO, M.; DEMPSEY, B. A.; CORNWELL, D. A. Engineering behavior of water treatment sludge. Journal of Environmental Engineering, v. 118, n. 6, p. 848-864, 1992.

WANG, M. C.; HULL, J. Q.; JAO, M. STABILIZATION OF WATER TREATMENT PLANT SLUDGE FOR POSSIBLE USE AS EMBANKMENT MATERIAL. Transportation Research Record, n. 1345, p. 36-43, 1992. 
WANG, M. C.; TSENG, W. Permeability behavior of a water treatment sludge. Journal of geotechnical engineering, v. 119, n. 10, p. 1672-1677, 1993.

WATANABE, Y.; KOMINE, H.; YASUHARA, K.; MURAKAMI, S. Batch Leaching Test Focusing on Clod Size of Drinking Water Sludge and Applicability to LongTerm Prediction Using Column Leaching Test. Geo-Frontiers 2011@ Advances in Geotechnical Engineering. Anais...ASCE, 2011.

WILLIAMS, C. E. Containment applications for earthen liners. 1987 Speciality Conference on Environmental Engineering. Proceedings...ASCE, 1987.

XIA, Z. Geotechnical characterization of water treatment plant residuals. 1994. 88p. Master Dissertation -New Jersey Institute of Technology, New Jersey, 1994.

ZANON, T. V. B. Avaliação da contaminação de um solo laterítico por lixiviado de aterro sanitário através de ensaios de laboratório e de retroanálise de campo. 2014. 101p. Dissertação (Mestrado) — Universidade de São Paulo, São Paulo, 2014. 